WSRC-TR-93-289

Rev 0

\title{
Semi-Annual Sampling of Fourmile Branch and its Seeplines in the F and H Areas of SRS: July 1992 (U)
}

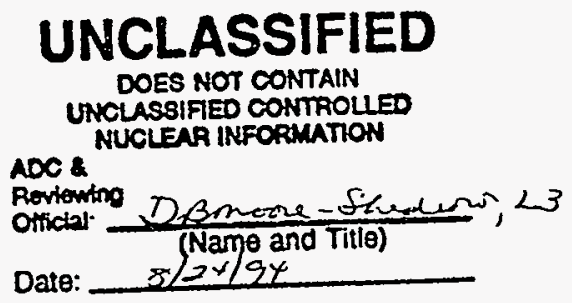

Westinghouse Savannah River Company Savannah River Site Aiken, SC 29808

Prepared for the U.S. Department of Energy under contract no. DE-AC09-89SR18035 


\section{Disclaimer}

This report was prepared as an account of work sponsored by an agency of the United States Government. Neither the United States Government nor any agency thereof, nor any of their employees, makes any warranty, express or implied, or assumes any legal liability or responsibility for the accuracy, completeness, or usefulness of any information, apparatus, product, or process disclosed, or represents that its use would not infringe privately owned rights. Reference herein to any specific commercial produch, process, or service by trade name, trademark, manufacturer, or otherwise does not necessarily constitute or imply its endorsement, recommendation, or favoring by the United States Government or any agency thereof. The views and opinions of authors expressed herein do not necessarily state or reflect those of the United States Government or any agency thereof. 


\section{DISCLAIMER}

Portions of this document may be illegible in electronic image products. Images are produced from the best available original document. 


\section{Semi-AnnualSampling of Fourmile Branch and its Seeplines in the F and H Areas of SRS: July 1992 (U)}

by

K. L. Dixon

Westinghouse Savannah River Company

Savannah River Site

Aiken, South Carolina 29808

V. A. Rogers

Westinghouse Savannah River Company

SC USA

DOE Contract No. DE-AC09-89SR18035

This paper was prepared in connection with work done under the above contract number with the U.S.

Department of Energy. By acceptance of this paper, the publisher and/or recipient acknowledges the U.S. Government's right to retain a nonexclusive, royalty-free license in and to any copyright covering this paper, along with the right to reproduce and to authorize others to reproduce all or part of the copyrighted paper. 
Semi-Annual Sampling of Fourmile Branch and Its Seeplines in the $F$ and $H$ Areas of SRS: July 1992 (U)

K. L. Dixon and V. A. Rogers

Prepared for the U.S. Department of Energy under contract no. DE-AC09-89SR18035 


\section{Contents}

\section{Executive Summary 7}

\section{Introduction 9}

\section{Methods 12}

Sampling Locations 16

Decontamination Procedures 18

Sample Collection Procedures 18

Seepline Water 18

Stream Water Sampling 18

Sample Processing 18

\section{Discussion 21}

Stream and Seepline Water Conductivity and pH 21

Comparison of Seepline Locations to Background Locations 22

Comparison of Stream and Seepline Locations to Established Standards 27

Comparison of 1989 and July 1992 Stream and Seepline Locations 31

Technetium-99 Results 34

Summary 35

References 36

Analytical Results $\mathbf{3 8}$

Appendix A: July 1992 Sampling Event 93

Experimental Methods 96

Mobilization 96

Equipment List 96 .

Decontamination Procedures 96

Sample Collection Procedures 96

Groundwater 96

Surface Water Sampling 97

\section{Results 99}

Conclusions 105

References 105

Appendix B: Plots of Analyte Concentrations as a Function of Seepline Areas 107 
WSRC-TR-93-289 


\section{List of Figures}

Figure 1. Location of F-Area Seepage Basins, Seepline Sampling Points (FSP), and Fourmile Branch Sampling Points 17

Figure 2. Location of H-Area Seepage Basins, Seepline Sampling Points (HSP), and Fourmile Branch Sampling Points 17

Figure A-1. Conductivity Measurements in H Area 101

Figure A-2. Conductivity Measurements in F Area 102

Figure A-3. $\mathrm{pH}$ Measurements in H Area 102

Figure A-4. $\mathrm{pH}$ Measurements in F Area 103

Figure B-1. Aluminum $(\mu \mathrm{g} / \mathrm{L}) \quad 110$

Figure B-2. Alkalinity (mg/L) 110

Figure B-3. Barium $(\mu \mathrm{g} / \mathrm{L}) \quad 110$

Figure B-4. Nonvolatile beta (pCi/L) 110

Figure B-5. Calcium $(\mu g / L) \quad 111$

Figure B-6. Chloride (mg/L) 111

Figure B-7. Gross alpha (pCi/L) 111

Figure B-8. Hardness (mg/L) 111

Figure B-9. Mercury $(\mu \mathrm{g} / \mathrm{L}) \quad 112$

Figure B-11. Lead $(\mu g / L) 112$

Figure B-10. Potassium $(\mu \mathrm{g} / \mathrm{L}) \quad 112$

Figure B-12. Magnesium $(\mu \mathrm{g} / \mathrm{L}) \quad 112$

Figure B-13. Manganese $(\mu \mathrm{g} / \mathrm{L}) \quad 113$

Figure B-14. Nitrate (mg/L) 113

Figure B-15. Radium-226 (pCi/L) 113

Figure B-16. Radium-228 (pCi/L) 113

Figure B-17. Sodium $(\mu g / L) \quad 114$

Figure B-18. Strontium-90 (pCi/L) 114

Figure B-19. Total organic carbon (mg/L) 114

Figure B-20. Total organic halogens $(\mu g / L) \quad 114$

Figure B-21. Tritium (pCi/ml) 115

Figure B-22. Zinc $(\mu \mathrm{g} / \mathrm{L}) \quad 115$ 
WSRC-TR-93-289 


\section{List of Tables}

Table 1. PDWS, MCL, and SDWS Standards Used in Data Comparisons 10

Table 2. Methods and Detection Limits for General Engineering (GE) and Environmental Physics (GP) Analyses 12

Table 3. Methods and Detection Limits for Weston Analytics (WA) and Clemson Technical Center (CN) Analyses 14

Table 4. FMC Stream and Seepline Sampling Locations 16

Table 5. Comparison of FSP and HSP Sampling Locations to Background Locations 23

Table 6. List of Mean Concentrations and Ranges for Analytes Used in Statistical Analysis 23

Table 7. Analytes Reported at Concentrations Greater Than Their Method Detection Limit 28

Table 8. Analytes and Corresponding Sampling Locations Where July 1992 Concentrations Exceeded Either the PDWS or MCL 28

Table 9. Analytes and Corresponding Sampling Locations Where July 1992 Concentrations Exceeded the SDWS 29

Table 10. Correlation Between 1989 and July 1992 Sampling Locations 32

Table 11. Analytes and Corresponding Sampling Locations Where 1992 Concentrations Exceeded 1989 Concentrations 32

Table 12. Analytes and Corresponding Sampling Locations Where 1992 Concentrations . Exceeded 1989 Concentrations and Either the PDWS or MCL 33

Table 13. Comparison of 99Tc Results Between Laboratories 34

Table 14. Analytical Modifiers 38

Table 15. BG001 Laboratory Analyses 39

Table 16. BG002 Laboratory Analyses 41

Table 17. BG003 Laboratory Analyses 43

Table 18. FMC001F Laboratory Analyses 45

Table 19. FMCO01H Laboratory Analyses 47

Table 20. FMC002H Laboratory Analyses 49

Table 21. FSP012 Laboratory Analyses 51

Table 22. FSP032 Laboratory Analyses 53

Table 23. FSPO47 Laboratory Analyses 55

Table 24. FSP204 Laboratory Analyses 59

Table 25. FSP290 Laboratory Analyses 61

Table 26. HSPO08 Laboratory Analyses 66

Table 27. HSP029 Laboratory Analyses 71

Table 28. HSP043 Laboratory Analyses 73 
Table 29. HSP060 Laboratory Analyses 77

Table 30. HSP092 Laboratory Analyses 79

Table 31. QA 2S Laboratory Analyses 81

Table 32. QA 4S Laboratory Analyses 83

Table 33. QA1 Laboratory Analyses 85

Table 34. QA2 Laboratory Analyses 87

Table 35. QA3 Laboratory Analyses 89

Table 36. QA4 Laboratory Analyses 91

Table A-1. Sample Location Numbers and SRS Coordinates 95

Table A-2. Depth Water Encountered 97

Table A-3. Water Quality Parameters Measured 99

Table A-4. Summary of Conductivity Measurements 100

Table A-5. Summary of $\mathrm{pH}$ Measurements 100 


\title{
Semi-Annual Sampling of Fourmile Branch and Its Seeplines in the F and H Areas of SRS: July 1992
}

\author{
K. L. Dixon and V. A. Rogers
}

\section{Executive Summary}

In July 1992, water samples were collected from Fourmile Branch (FMB) and its seeplines in the vicinity of the Fand $\mathrm{H}$-Area seepage basins. The samples were collected from five seepline locations in F Area, five seepline locations in $\mathrm{H}$ Area, and three stream locations on FMB. The sampling event was the first in a series of three semiannual sampling events aimed at characterizing the shallow groundwater outcropping into FMB and its wetlands. In the past, this groundwater has been shown to contain contaminants migrating from the $\mathrm{F}$ - and $\mathrm{H}$-Area seepage basins. The samples were analyzed for Appendix IX metals, various radionuclides, selected volatile compounds, and selected inorganic constituents and parameters.

Results from the July 1992 sampling event suggest that the seeplines in both F and H Areas and FMB continue to be influenced by contaminants migrating from the $\mathrm{F}$ - and $\mathrm{H}$ Area seepage basins. However, when compared to 1989 measurements (Haselow et al. 1990), the concentrations of most of the constituents have declined.

Contaminant concentrations measured in July 1992 were compared to primary drinking water standards (PDWS), secondary drinking water standards (SDWS), and maximum contaminant levels (MCL) enforceable in 1993. Results were also compared to 1989 measurements at corresponding sampling locations and to background samples collected as part of the July 1992 sampling event.

Using two different statistical tests, concentrations of selected F- and H-Area seepline analytes were compared to background samples. These tests were designed to detect if concentrations of contaminants along the F- and $\mathrm{H}$-Area seeplines were greater than background concentrations.
Analytes detected with concentrations significantly greater than background (at a Type 1 error rate of 0.05 ) using the two statistical tests were:

\begin{tabular}{cc} 
Area & Analytes \\
\hline F & alkalinity, barium, calcium, manganese, ${ }^{3} \mathrm{H}$ \\
H & alkalinity, aluminum, calcium, sodium, ${ }^{3} \mathrm{H},{ }^{226} \mathrm{Ra}$
\end{tabular}

None of the metals or volatile organic compounds analyzed were found to be elevated above the PDWS or MCL. Those contaminants elevated above the PDWS or MCL were

\begin{tabular}{cc} 
Area & Analytes \\
\hline $\mathrm{F}$ & nitrate, nonvolatile beta, ${ }^{3} \mathrm{H},{ }^{129} \mathrm{I},{ }^{228} \mathrm{Ra},{ }^{90} \mathrm{Sr},{ }^{99} \mathrm{Tc}$ \\
$\mathrm{H}$ & nitrate, gross alpha, nonvolatile beta, ${ }^{3} \mathrm{H},{ }^{129} \mathrm{I}$ \\
& ${ }^{228}{ }_{\mathrm{Ra}}{ }^{90} \mathrm{Sr},{ }^{99} \mathrm{Tc}$ \\
FMB & nonvolatile beta, ${ }^{3} \mathrm{H},{ }^{129} \mathrm{~L},{ }^{228} \mathrm{Ra},{ }^{90} \mathrm{Sr},{ }^{99} \mathrm{~T}$ \\
\hline
\end{tabular}

Those analytes found to be elevated above 1989 measurements at one or more location were:

\begin{tabular}{cl} 
Area & \multicolumn{1}{c}{ Analytes } \\
\hline F & aluminum, chloride, mercury, ${ }^{129} \mathrm{I}$ \\
$\mathrm{H}$ & $\begin{array}{l}\text { aluminum, chloride, mercury, lead, sodium, zinc, } \\
{ }^{129} \mathrm{I}\end{array}$ \\
FMB & $\begin{array}{c}\text { alkalinity, chloride, mercury, sodium, zinc, }{ }^{137} \mathrm{Cs}, \\
\end{array}{ }^{226} \mathrm{Ra},{ }^{90} \mathrm{Sr}$
\end{tabular}


It should be noted that most of the nonradiological parameters, particularly sodium and aluminum, have declined in concentration at both F- and $\mathrm{H}$-Area seeplines and in FMB.

Several seepline locations in both $\mathrm{F}$ and $\mathrm{H}$ Area continue to be influenced by ${ }^{129} \mathrm{I}$ and ${ }^{90} \mathrm{Sr}$. Contributions of ${ }^{90} \mathrm{Sr}$, ${ }^{129} \mathrm{I},{ }^{3} \mathrm{H}$, and ${ }^{137} \mathrm{Cs}$ from the $\mathrm{F}$ - and $\mathrm{H}$-Area seepage basin operations continue to be measurable in FMB.
While the July 1992 results suggest that contaminant levels have declined somewhat since 1989, the concentrations of some radionuclides have remained unchanged. Further analysis based on future data from the semiannual sampling program will allow for a more complete assessment of the temporal changes in the contaminant levels at FMB and its seeplines. 


\section{Introduction}

Seepage basins in the $\mathrm{F}$ and $\mathrm{H}$ Areas of the Savannah River Site (SRS) received low-level radioactive waste effluent from the chemical separation processes in the General Separation Areas (GSA). The basins retained the effluent to delay its release to the environment. The waste effluent consisted principally of sodium hydroxide, nitric acid, low levels of various radionuclides, and some metals (Killian et al. 1985a and b). Discharges of tritiated water to the seepage basins account for most of the radioactivity (Fenimore and Horton 1972). Other relatively mobile radionuclides introduced into the basins via the waste effuent were ${ }^{90} \mathrm{Sr},{ }^{99} \mathrm{Tc}$, and ${ }^{129} \mathrm{I}$ (Looney et al. 1988).

In 1988 and 1989, the Savannah River Laboratory (now the Savannah River Technology Center) conducted an extensive study aimed at characterizing the shallow groundwater outcropping into Fourmile Branch and its associated seepline (Looney et al. 1988, Haselow et al. 1990). These studies were prompted by observed vegetation stress in relatively small isolated areas of the wetlands on the northern side of Fourmile Branch.

Looney et al. (1988) collected water samples from upstream and downstream locations on Fourmile Branch and from its associated seeplines in suspect areas. The samples were analyzed for a wide range of non-radioactive parameters including selected metals, inorganic constituents and parameters, $\mathrm{pH}$, conductivity, nitrate, and nitrite. Results from the analysis of the seepwater suggested that

- sodium, nitrate, and hydrogen ions had reached the seepline from the basins and were affecting the bulk chemistry of the seepwater

- several constituents (aluminum, calcium, copper, etc.) were being leached from the soil profile by the low $\mathrm{pH}$ shallow groundwater

- cadmium in F Area and nitrate in both F and $\mathrm{H}$ Area were elevated above primary drinking water standards

- Fourmile Branch was being impacted by constituents (primarily nitrate and sodium) input by either the seepwater or local outfalls

Looney et al. (1988) concluded that these factors, combined with the flooding of previously dry areas resulting from basin operations, were primarily responsible for the observed vegetation stress in the seep areas and suggested that a more extensive study be performed to further characterize the occurrence of contaminants in the stream and seepwater.
Haselow et al. (1990) collected soil cores, stream, and seepline water samples from Fourmile Branch and its seeplines in 1988 and 1989 as a follow-up to the Looney et al. (1988) study. These samples were analyzed for both radioactive and non-radioactive parameters. Between the 1988 and 1989 sampling events, an extensive survey for tritium, pH, and conductivity was conducted along the seeplines. Results from these studies suggested that

- cadmium and nitrate concentrations along the F-Area seepline and nitrate concentrations along the H-Area seepline were above primary drinking water standards

- manganese and iron concentrations were above the secondary drinking water standards along both the F-and H-Area seeplines

- aluminum and sodium concentrations were apparently elevated along both the F- and H-Area seeplines although no standard existed for comparison

- gross alpha, nonvolatile beta, ${ }^{241} \mathrm{Am},{ }^{129} \mathrm{I},{ }^{3} \mathrm{H},{ }^{226} \mathrm{Ra}$, ${ }^{89} \mathrm{Sr}$, ${ }^{90} \mathrm{Sr}$, and ${ }^{233 / 234} \mathrm{U}$ were elevated above the proposed or established drinking water standard at one or more points along the F-Area seepline

- gross alpha, ${ }^{3} \mathrm{H},{ }^{226} \mathrm{Ra},{ }^{89} \mathrm{Sr}$, and ${ }^{90} \mathrm{Sr}$ were elevated above the proposed or established drinking water standard at one or more points along the H-Area seepline

- ${ }^{244} \mathrm{Am},{ }^{60} \mathrm{Co},{ }^{134} \mathrm{Cs}$, and ${ }^{136} \mathrm{Cs}$ had also impacted the seepline but were not above drinking water standards

- nonvolatile beta and tritium were above the Primary Drinking Water Standards (PDWS) in FMB at one or more points

- tritium and conductivity were elevated at several points along the F- and H-Area seeplines

- seepwater along the F- and H-Area seeplines generally exhibited low pH

- cadmium, nonvolatile beta, ${ }^{90} \mathrm{Sr},{ }^{233 / 234} \mathrm{U}$, and ${ }^{238} \mathrm{U}$ in the soil samples were elevated above SRS background values for soils in at least one sample

- ${ }^{241} \mathrm{Am},{ }^{244} \mathrm{Cm},{ }^{60} \mathrm{Co},{ }^{129} \mathrm{I},{ }^{238} \mathrm{Pu}$, and ${ }^{226} \mathrm{Ra}$ were also suspected to be above background levels in at least one sample, although no established background data existed for comparison

These studies confirmed that contaminants migrating from the seepage basins were impacting the water chemistry along the F- and H-Area seeplines.

Discharges to the seepage basins were discontinued in 1988 and the basins were capped and sealed in 1990 to minimize the release of contaminants to the environment. Scientists hypothesized that after eliminating the contaminant source, annual rainfall amounts and natural ground- 
water flow would, over time, dilute and flush the remaining contaminant plume out of the shallow groundwater and FMB wetland system. After the contaminant plume in the shallow groundwater is diluted and flushed out, the FMB wetland systems below the basins will begin to recover.

To investigate this hypothesis and to monitor the post-basin closure temporal changes in the contaminant levels outcropping along the FMB seepline, two sampling programs were established. These were the quarterly $\mathrm{F}$ - and $\mathrm{H}$-Area tritium survey and a semi-annual sampling program for monitoring Appendix IX metals, various inorganics, and selected radionuclides. Results from the quarterly tritium surveys, in which tritium, $\mathrm{pH}$, and conductivity are measured at several locations along the seepline, have been presented by Dixon and Rogers (1991a and b). The results have shown a significant decrease in tritium activities and conductivity values with $\mathrm{pH}$ values increasing to more natural (pH 5-6) ranges.

The objectives of this report are to

- present the results from the July 1992 sampling event of FMB and its seeplines

- compare, where possible, these results to established standards enforceable in 1993 (Table 1) and 1989 (Haselow et al., 1990) results where possible

- make inferences about the temporal changes in contaminant concentrations resulting from basin closure

Table 1. PDWS, MCL, and SDWS Standards Used in Data Comparisons

\begin{tabular}{|c|c|c|c|c|c|}
\hline Analyte & Standard & Units & Source & Status & \\
\hline 1,1,1-Trichloroethane & 200 & $\mu \mathrm{g} / \mathrm{L}$ & EPA, 1993 & 93-MCL & \\
\hline Aluminum & NS* & & & & \\
\hline Americium-241 & 6.34 & $\mathrm{pCi} / \mathrm{L}$ & EPA 1991c & Proposed & \\
\hline Antimony & 5 & $\mu g / L$ & EPA 1990 & Proposed & \\
\hline Antimony-125 & 300 & $\mathrm{pCi} / \mathrm{L}$ & EPA, 1977 & Final & \\
\hline Arsenic & 50 & $\mu \mathrm{g} / \mathrm{L}$ & EPA, 1993 & 93-MCL & \\
\hline Barium & 2000 & $\mu \mathrm{g} / \mathrm{L}$ & EPA, 1993 & 93-MCL & \\
\hline Beryllium & 1 & $\mu g / L$ & EPA, 1990 & Proposed & \\
\hline Cadmium & 5 & $\mu g / L$ & EPA, 1993 & 93-MCL & \\
\hline Calcium & NS & & & & \\
\hline Carbon tetrachloride & 5 & $\mu g / L$ & EPA, 1993 & 93-MCL & \\
\hline Cerium-144 & 261 & $\mathrm{pCi} / \mathrm{L}$ & EPA, 1991c & Proposed & \\
\hline Cesium-134 & 81.3 & $\mathrm{pCi} / \mathrm{L}$ & EPA, 1991c & Proposed & \\
\hline Cesium-137 & 200 & $\mathrm{pCi} / \mathrm{L}$ & EPA, 1991c & Proposed & . \\
\hline Chloride & NS & & & & \\
\hline Chloroform & 100 & $\mu \mathrm{g} / \mathrm{L}$ & EPA, 1991a & Final & \\
\hline Chromium & 100 & $\mu g / L$ & EPA, 1993 & 93-MCL & \\
\hline Cobalt-57 & 1000 & $\mathrm{pCi} / \mathrm{L}$ & EPA, 1977 & Final & \\
\hline Cobalt- 60 & 100 & $\mathrm{pCi} / \mathrm{L}$ & EPA, 1977 & Final & \\
\hline Copper & 1300 & $\mu g / L$ & EPA, 1993 & 93-MCL & \\
\hline Curium-242 & 0.133 & $\mathrm{pC} / / \mathrm{L}$ & EPA, $1991 \mathrm{c}$ & Proposed & \\
\hline Curium-243,244 & 8.3 & $\mathrm{pCi} / L$ & EPA, 1991c & Proposed & \\
\hline Europium-152 & NS & & & & \\
\hline Europium-154 & 200 & $\mathrm{pCi} / \mathrm{L}$ & EPA, 1977 & Final & \\
\hline Europium-155 & 600 & $\mathrm{pCi} / \mathrm{L}$ & EPA, 1977 & Final & \\
\hline Fluoride & 4 & $\mathrm{mg} / \mathrm{L}$ & EPA, 1991a & Final & \\
\hline Gross alpha & 15 & $\mathrm{pCi} / \mathrm{L}$ & EPA, 1993 & 93-MCL & \\
\hline Iodine-129 & 1 & $\mathrm{pCi} / \mathrm{L}$ & EPA, 1977 & Final & \\
\hline Iron & 300 & $\mu g / L$ & EPA, $1991 \mathrm{~b}$ & & \\
\hline Lead & 15 & $\mu \mathrm{g} / \mathrm{L}$ & EPA, 1993 & 93-MCL & \\
\hline Magnesium & NS & & & & \\
\hline Manganese & 50 & $\mu \mathrm{g} / \mathrm{L}$ & EPA, 1991b & & \\
\hline Manganese-54 & 300 & $\mathrm{pCi} / \mathrm{L}$ & EPA, 1977 & Final & \\
\hline Mercury & 2 & $\mu \mathrm{g} / \mathrm{L}$ & EPA, 1993 & 93-MCL & \\
\hline Neptunium-237 & 7.06 & $\mathrm{pCi} / \mathrm{L}$ & EPA, 1991c & Proposed & \\
\hline
\end{tabular}


(Table 1. Continued)

\begin{tabular}{|c|c|c|c|c|}
\hline Analyte & Standard & Units & Source & Status \\
\hline Nickel & 100 & $\mu g / L$ & EPA, 1990 & Proposed \\
\hline Nitrate as nitrogen & 10 & $\mathrm{mg} / \mathrm{L}$ & EPA, 1993 & 93-MCL \\
\hline Nonvolatile beta & 50 & $\mathrm{pCi} / 1$ & EPA, 1986b & Proposed \\
\hline Plutonium-238 & 7.02 & $\mathrm{pCi} / \mathrm{L}$ & $\mathrm{EPA}, 1991 \mathrm{c}$ & Proposed \\
\hline Plutonium-239,240 & 62.1 & $\mathrm{pCi} / \mathrm{L}$ & EPA, 1991c & Proposed \\
\hline Potassium & NS & & & \\
\hline Potassium-40 & 300 & $\mathrm{pCi} / \mathrm{L}$ & EPA, 1986b & Proposed \\
\hline Promethium-144 & NS & & & \\
\hline Promethium-146 & NS & & & \\
\hline Radium-226 & 15.7 & $\mathrm{pCi} / \mathrm{L}$ & EPA, 1991c & Proposed \\
\hline Radium-228 & 7.85 & $\mathrm{pCi} / \mathrm{L}$ & EPA, 1991c & Proposed \\
\hline Ruthenium-106 & 30 & $\mathrm{pCi} / \mathrm{L}$ & EPA, 1977 & Final \\
\hline Selenium & 50 & $\mu \mathrm{g} / \mathrm{L}$ & EPA, 1991a & Final \\
\hline Silver & 50 & $\mu g / L$ & EPA, 1991a & Final \\
\hline Sodium & NS & & & \\
\hline Sodium-22 & 466 & $\mathrm{pCi} / \mathrm{L}$ & EPA, 1991c & Proposed \\
\hline Strontium-90 & 8 & $\mathrm{pCi} / \mathrm{L}$ & EPA, 1993 & 93-MCL \\
\hline Technetium-99 & 900 & $\mathrm{pCi} / \mathrm{L}$ & EPA, 1977 & Final \\
\hline Thallium & 1 & $\mu g / L$ & EPA, 1990 & Proposed \\
\hline Thorium-228 & 125 & $\mathrm{pCi} / \mathrm{L}$ & EPA, 1991c & Proposed \\
\hline Thorium-230 & 79.2 & $\mathrm{pCi} / \mathrm{L}$ & EPA, 1991c & Proposed \\
\hline Thorium-232 & 88 & $\mathrm{pCi} / \mathrm{L}$ & EPA, 1991c & Proposed \\
\hline Tin & NS & & & \\
\hline Total organic carbon & NS & & & \\
\hline Total organic halogens & NS & & & \\
\hline Total phenols & NS & & & \\
\hline Trichloroethylene & 5 & $\mu g / L$ & EPA, 1991a & Final \\
\hline Tetrachloroethylene & 5 & $\mu g / L$ & EPA, 1991a & Final \\
\hline Tritium & 20 & $\mathrm{pCi} / \mathrm{ml}$ & EPA, 1993 & 93-MCL \\
\hline Uranium-234 & 13.9 & $\mathrm{pCi} / \mathrm{L}$ & EPA, 1991c & Proposed \\
\hline Uranium-235 & 14.5 & $\mathrm{pCi} / \mathrm{L}$ & EPA, 1991c & Proposed \\
\hline Uranium-238 & 14.6 & $\mathrm{pC} / \mathrm{L}$ & EPA, 1991c & Proposed \\
\hline Vanadium & NS & & & \\
\hline Yttrium-88 & NS & & & \\
\hline Zinc & 5000 & $\mu g / L$ & EPA, 1991b & \\
\hline Zinc-65 & 300 & $\mathrm{pCi} / \mathrm{L}$ & EPA, 1977 & Proposed \\
\hline
\end{tabular}

*NS = No Standard 


\section{Methods}

Seepline water sampling services were obtained via task order under contract AA46327P (Task 26) with Metcalf and Eddy, Inc. Metcalf and Eddy subcontracted the field sampling portion of the task to Normandeau Associates, Inc. Sampling activities occurred between July 20, 1992 and July 29, 1992 and have been described in detail by Metcalf and Eddy (1992) and are reproduced in part for this discussion and completely in Appendix A.

Analytical services were arranged for by the WSRC-Environmental Monitoring Section (EMS) and were provided by a combination of several laboratories. General Engineering (nonradiological analyses) and Environmental Physics (radiological analyses) were used as the primary laboratories. Weston Analytics (nonradiological analyses) and Clemson Technical Center (radiological analyses) were used for split sample analyses. The laboratories provided all sample containers with preservatives, blue ice, and coolers necessary to collect and ship the samples. Chain of custody forms and packing materials were provided by EMS. At each location, a sample was collected to measure for total activity for shipping clearance. These analyses were performed onsite by EMS. A list of the constituents analyzed by each lab, plus the methods used and method detection limits, is given in Tables 2 and 3.

Confirmation analysis was performed for ${ }^{99} \mathrm{Tc}$ on several samples by the Environmental Technology Section (ETS) of SRTC using an isotope dilution inductively coupled plasma - mass spectrometry procedure (ICP/MS) (Beals 1992). The method detection limit for this procedure was 5 $\mathrm{pCi} / \mathrm{L}$.

Table 2. Methods and Detection Limits for General Engineering (GE) and Environmental Physics (GP) Analyses

\begin{tabular}{|c|c|c|c|c|c|}
\hline Analyte & Method & Source & Detection Limit & Units & $\mathbf{L a b}$ \\
\hline 1,1,1-trichloroethylene & EPA801 & $\overline{E P A}, 1986 a$ & 1 & $\mu \mathrm{g} / \mathrm{L}$ & $\overline{G E}$ \\
\hline Alkalinity & EPA310.1 & EPA, 1983 & 1 & $\mathrm{mg} / \mathrm{L}$ & GE \\
\hline Aluminum & EPA 6010 & EPA, 1986a & 20 & $\mu g / L$ & GE \\
\hline Americium-241 & HAS300 & DOE, 1992 & 1 & $\mathrm{pCi} / \mathrm{L}$ & $G P$ \\
\hline Ammonia nitrogen & EPA350.1 & EPA, 1983 & 0.1 & $\mathrm{mg} / \mathrm{L}$ & GE \\
\hline Antimony & EPA7041 & EPA, 1986a & 2 & $\mu g / L$ & GE \\
\hline Antimony-125 & HASL 300 & DOE, 1992 & 20 & $\mathrm{pCi} / \mathrm{L}$ & GP \\
\hline Arsenic & EPA7060 & EPA, 1986a & 2 & $\mu g / L$ & GE \\
\hline Barium & EPA 6010 & EPA, 1986a & 3 & $\mu g / L$ & $\mathrm{GE}$ \\
\hline Beryllium & EPA6010 & EPA, 1986a & 3 & $\mu g / L$ & $\mathrm{GE}$ \\
\hline Cadmium & EPA6010 & EPA, 1986a & 2 & $\mu \mathrm{g} / \mathrm{L}$ & $\mathrm{GE}$ \\
\hline Calcium & EPA6010 & EPA, 1986a & 10 & $\mu g / L$ & GE \\
\hline Carbon tetrachloride & EPA8010 & EPA, 1986a & 1 & $\mu g / L$ & $\mathrm{GE}$ \\
\hline Cerium-144 & HASL300 & DOE, 1992 & 60 & $\mathrm{pCi} / \mathrm{L}$ & GP \\
\hline Cesium-134 & HASL300 & DOE, 1992 & 10 & $\mathrm{pCi} / \mathrm{L}$ & GP \\
\hline Cesium-137 & HASL300 & DOE, 1992 & 10 & $\mathrm{pCi} / \mathrm{L}$ & GP \\
\hline Chloride & EPA300.0 & EPA, 1983 & 0.25 & $\mathrm{mg} / \mathrm{L}$ & GE \\
\hline Chloroform & EPA8010 & EPA, 1986 & 1 & $\mu g / L$ & GE \\
\hline Chromium & EPA6010 & EPA, 1986a & 4 & $\mu g / L$ & GE \\
\hline Cobalt-57 & HASL300 & DOE, 1992 & 10 & $\mathrm{pCi} / \mathrm{L}$ & GP \\
\hline Cobalt -60 & HASL300 & DOE, 1992 & 10 & $\mathrm{pCi} / \mathrm{L}$ & GP \\
\hline Copper & EPA6010 & EPA, 1986a & 4 & $\mu g / L$ & GE \\
\hline Curium-242 & HASL300 & DOE, 1992 & 1 & $\mathrm{pCi} / \mathrm{L}$ & GP \\
\hline Curium-243,244 & HASL300 & DOE, 1992 & 1 & $\mathrm{pCi} / \mathrm{L}$ & GP \\
\hline Europium-152 & HASL300 & DOE, 1992 & 40 & $\mathrm{pCi} / \mathrm{L}$ & GP \\
\hline Europium-154 & HASL300 & DOE, 1992 & 20 & $\mathrm{pCi} / \mathrm{L}$ & GP \\
\hline Europium-155 & HASL300 & DOE, 1992 & 30 & $\mathrm{pCi} / \mathrm{L}$ & GP \\
\hline Fluoride & EPA340.2 & EPA, 1983 & 0.1 & $\mathrm{mg} / \mathrm{L}$ & $\mathrm{GE}$ \\
\hline Gross alpha & EPA900.0 & EPA, 1980 & 2 & $\mathrm{pCi} / \mathrm{L}$ & GE \\
\hline Hardness & EPA130.2 & EPA, 1983 & 1 & $\mathrm{mg} / \mathrm{L}$ & GE \\
\hline Iodine-129 & HASL300 & DOE, 1992 & 2 & $\mathrm{pCi} / \mathrm{L}$ & $\mathrm{TE}$ \\
\hline
\end{tabular}


(Table 2. Continued)

\begin{tabular}{|c|c|c|c|c|c|}
\hline Analyte & Method & Source & Detection Limit & Units & Lab \\
\hline Iron & EPA6010 & EPA, 1986a & 4 & $\mu g / L$ & $\mathrm{GE}$ \\
\hline Lead & EPA7421 & EPA, 1986a & 3 & $\mu g / L$ & GE \\
\hline Magnesium & EPA6010 & EPA, 1986a & 2 & $\mu g / L$ & $\mathrm{GE}$ \\
\hline Manganese & EPA6010 & EPA, 1986a & 2 & $\mu g / L$ & GE \\
\hline Manganese-54 & HASL300 & DOE, 1992 & 10 & $\mathrm{pCi} / \mathrm{L}$ & GP \\
\hline Mercury & EPA7470 & EPA, 1986a & 0.2 & $\mu \mathrm{g} / \mathrm{L}$ & GE \\
\hline Neptunium-237 & HASL300 & DOE, 1992 & 10 & $\mathrm{pCi} / \mathrm{L}$ & $\mathrm{TE}$ \\
\hline Nickel & EPA6010 & EPA, 1986a & 4 & $\mu g / L$ & GE \\
\hline Nitrate as nitrogen & EPA353.3 & EPA, 1983 & 0.05 & $\mathrm{mg} / \mathrm{L}$ & $\mathrm{GE}$ \\
\hline Nonvolatile beta & EPA900.0 & EPA, 1980 & 2 & $\mathrm{pCi} / \mathrm{L}$ & GE \\
\hline Plutonium-238 & HASL300 & DOE, 1992 & 1 & $\mathrm{pCi} / \mathrm{L}$ & GP \\
\hline Plutonium-239,240 & HASL300 & DOE, 1992 & 1 & $\mathrm{pCi} / \mathrm{L}$ & GP \\
\hline Potassium & EPA6010 & EPA, 1986a & 500 & $\mu g / L$ & GE \\
\hline Potassium-40 & HASL300 & DOE, 1992 & 110 & $\mathrm{pCi} / \mathrm{L}$ & GP \\
\hline Promethium-144 & HASL300 & DOE, 1992 & 10 & $\mathrm{pCi} / \mathrm{L}$ & GP \\
\hline Promethium-146 & HASL300 & DOE, 1992 & 10 & $\mathrm{pCi} / \mathrm{L}$ & GP \\
\hline Radium-226 & HASL300 & DOE, 1992 & 1 & $\mathrm{pCi} / \mathrm{L}$ & GP \\
\hline Radium-228 & HASL300 & DOE, 1992 & 1 & $\mathrm{pCi} / \mathrm{L}$ & GP \\
\hline Ruthenium-106 & HASL300 & DOE, 1992 & 90 & $\mathrm{pCi} / \mathrm{L}$ & GP \\
\hline Selenium & EPA7740 & EPA, 1986a & 2 & $\mu \mathrm{g} / \mathrm{L}$ & GE \\
\hline Silver & EPA6010 & EPA, 1986a & 2 & $\mu g / L$ & GE \\
\hline Sodium & EPA6010 & EPA, 1986a & 10 & $\mu g / L$ & GE \\
\hline Sodium-22 & HASL300 & DOE, 1992 & 10 & $\mathrm{pCi} / \mathrm{L}$ & GP \\
\hline Strontium-90 & HASL300 & DOE, 1992 & 2 & $\mathrm{pCi} / \mathrm{L}$ & GP \\
\hline Technetium-99 & HASL300 & DOE, 1992 & 300 & $\mathrm{pCi} / \mathrm{L}$ & GP \\
\hline Tetrachloroethylene & EPA8010 & EPA, 1986a & 1 & $\mu g / L$ & GE \\
\hline Thallium & EPA7841 & EPA, 1986a & 2 & $\mu g / L$ & GE \\
\hline Thorium-228 & HASL300 & DOE, 1992 & 1 & $\mathrm{pCi} / \mathrm{L}$ & GP \\
\hline Thorium-230 & HASL300 & DOE, 1992 & 1 & $\mathrm{pC} / \Omega$ & GP \\
\hline Thorium-232 & HASL300 & DOE, 1992 & 1 & $\mathrm{pC} \mathrm{i} / \mathrm{L}$ & GP \\
\hline Tin & EPA6010 & EPA, 1986a & 2 & $\mu g / L$ & $\mathrm{GE}$ \\
\hline Total organic carbon & EPA9060 & EPA, 1986a & 1 & $\mathrm{mg} / \mathrm{L}$ & GE \\
\hline Total organic halogens & EPA9020 & EPA, 1986a & 5 & $\mu \mathrm{g} / \mathrm{L}$ & GE \\
\hline Total phenols & EPA420.2 & EPA, 1983 & 5 & $\mu g / L$ & GE \\
\hline Trichloroethylene & EPA8010 & EPA, 1986a & 1 & $\mu \mathrm{g} / \mathrm{L}$ & GE \\
\hline Tritium & EPA906.0 & EPA, 1980 & 0.7 & $\mathrm{pCi} / \mathrm{ml}$ & GE \\
\hline Uranium-234 & HASL300 & DOE, 1992 & 1 & $\mathrm{pCi} / \mathrm{L}$ & GP \\
\hline Uranium-235 & HASL300 & DOE, 1992 & 1 & $\mathrm{pCi} / \mathrm{L}$ & GP \\
\hline Uranium-238 & HASL300 & DOE, 1992 & 1 & $\mathrm{pCi} / \mathrm{L}$ & GP \\
\hline Vanadium & EPA6010 & EPA, 1986a & 8 & $\mu \mathrm{g} / \mathrm{L}$ & GE \\
\hline$\dot{Y}$ पtrium-88 & HASL30 & DOE, 1992 & 60 & $\mathrm{pCi} / \mathrm{L}$ & GP \\
\hline Zine & EPA6010 & EPA, 1986a & 2 & $\mu g / L$ & GE \\
\hline Zinc- 65 & HASL300 & DOE, 1992 & 20 & $\mathrm{pCi} / \mathrm{L}$ & GP \\
\hline
\end{tabular}


Table 3. Methods and Detection Limits for Weston Analytics (WA) and Clemson Technical Center (CN) Analyses

\begin{tabular}{|c|c|c|c|c|c|}
\hline Analyte & Method & Source & Detection Limit & Units & Lab \\
\hline 1,1,1-trichloroethylene & EPA8010 & EPA, 1986a & 1 & $\mu g / L$ & $\overline{\text { WA }}$ \\
\hline Aluminum & EPA200.7 & EPA, 1983 & 14.6 & $\mu g / L$ & WA \\
\hline Americium-241 & CTC0009 & CTC, 1992 & 1 & $\mathrm{pCi} / \mathrm{L}$ & $\mathrm{CN}$ \\
\hline Antimony & EPA200.7 & EPA, 1983 & 2.6 & $\mu g / L$ & WA \\
\hline Antimony-125 & EPA901.1 & EPA, 1980 & 20 & $\mathrm{pCi} / \mathrm{L}$ & $\mathrm{CN}$ \\
\hline Arsenic & EPA206.2 & EPA, 1983 & 2 & $\mu g / L$ & WA \\
\hline Barium & EPA200.7 & EPA, 1983 & 6.6 & $\mu \mathrm{g} / \mathrm{L}$ & WA \\
\hline Beryllium & EPA200.7 & EPA, 1983 & 0.18 & $\mu g / L$ & WA \\
\hline Cadmium & EPA200.7 & EPA, 1983' & 0.35 & $\mu g / L$ & WA \\
\hline Calcium & EPA200.7 & EPA, 1983 & 14.4 & $\mu g / L$ & WA \\
\hline Carbon tetrachloride & EPA8010 & EPA, 1986a & 1 & $\mu \mathrm{g} / \mathrm{L}$ & WA \\
\hline Cerium-144 & EPA901.1 & EPA, 1980 & 50 & $\mathrm{pC} \mathbf{i} / \mathrm{L}$ & $\mathrm{CN}$ \\
\hline Cesium-134 & EPA901.1 & EPA, 1980 & 10 & $\mathrm{pCi} / \mathrm{L}$ & $\mathrm{CN}$ \\
\hline Cesium-137 & EPA901.1 & EPA, 1980 & 10 & $\mathrm{pCi} / \mathrm{L}$ & $\mathrm{CN}$ \\
\hline Chloride & EPA325.2 & EPA, 1983 & 0.25 & $\mathrm{mg} / \mathrm{L}$ & WA \\
\hline Chloroform & EPA8010 & EPA, 1986a & 1 & $\mu g / L$ & WA \\
\hline Chromium & EPA200.7 & EPA, 1983 & 1.1 & $\mu \mathrm{g} / \mathrm{L}$ & WA \\
\hline Cobalt-57 & EPA901.1 & EPA, 1980 & 10 & $\mathrm{pCi} / \mathrm{L}$ & $\mathrm{CN}$ \\
\hline Cobalt -60 & EPA901.1 & EPA, 1980 & 10 & $\mathrm{pCi} / \mathrm{L}$ & $\mathrm{CN}$ \\
\hline Copper & EPA200.7 & EPA, 1983 & 1.1 & $\mu g / L$ & WA \\
\hline Curium-242 & CTC0009 & CTC, 1992 & 1 & $\mathrm{pCi} / \mathrm{L}$ & $\mathrm{CN}$ \\
\hline Curium-243, 244 & CTC0009 & CTC, 1992 & 1 & $\mathrm{pCi} / \mathrm{L}$ & $\mathrm{CN}$ \\
\hline Europium-152 & EPA901.1 & EPA, 1980 & 40 & $\mathrm{pCi} / \mathrm{L}$ & $\mathrm{CN}$ \\
\hline Europium-154 & EPA901.1 & EPA, 1980 & 25 & $\mathrm{pCi} / \mathrm{L}$ & $\mathrm{CN}$ \\
\hline Europium-155 & EPA901.1 & EPA, 1980 & 25 & $\mathrm{pCi} / \mathrm{L}$ & $\mathrm{CN}$ \\
\hline Fluoride & EPA340.2 & EPA, 1983 & 0.1 & $\mathrm{mg} / \mathrm{L}$ & WA \\
\hline Gross alpha & EPA900.0 & EPA, 1980 & 1.9 & $\mathrm{pCi} / \mathrm{L}$ & TM \\
\hline Iodine-129 & EPA901.1 & EPA, 1980 & 2 & $\mathrm{pCi} / \mathrm{L}$ & $\mathrm{CN}$ \\
\hline Iron & EPA200.7 & EPA, 1983 & 1.9 & $\mu g / L$ & WA \\
\hline Lead & EPA239.2 & EPA, 1983 & 2 & $\mu g / L$ & WA \\
\hline Magnesium & EPA200.7 & EPA, 1983 & 8.9 & $\mu g / L$ & WA \\
\hline Manganese & EPA200.7 & EPA, 1983 & 0.35 & $\mu g / L$ & WA \\
\hline Manganese-54 & EPA901.1 & EPA, 1980 & 10 & $\mathrm{pCi} / \mathrm{L}$ & $\mathrm{CN}$ \\
\hline Mercury & EPA245.1 & EPA, 1983 & 0.2 & $\mu g / L$ & WA \\
\hline Neptunium-237 & EPA901.1 & EPA, 1980 & 45 & $\mathrm{pCi} / \mathrm{L}$ & $\mathrm{CN}$ \\
\hline Nickel & EPA200.7 & EPA, 1983 & 3.1 & $\mu g / L$ & WA \\
\hline Nitrate as nitrogen & EPA353.2 & EPA, 1983 & 0.01 & $\mathrm{mg} / \mathrm{L}$ & WA \\
\hline Nonvolatile beta & EPA900.0 & EPA, 1980 & 2.1 & $\mathrm{pCi} / \mathrm{L}$ & TM \\
\hline Plutonium-238 & CTC0009 & CTC, 1992 & 1 & $\mathrm{pCi} / \mathrm{L}$ & $\mathrm{CN}$ \\
\hline Plutonium-239, 240 & CTC0009 & CTC, 1992 & 1 & $\mathrm{pCi} / \mathrm{L}$ & $\mathrm{CN}$ \\
\hline Potassium & EPA200.7 & EPA, 1983 & 83.5 & $\mu g / L$ & WA \\
\hline Potassium -40 & EPA901.1 & EPA, 190 & 175 & $\mathrm{pCi} / \mathrm{L}$ & $\mathrm{CN}$ \\
\hline Promethium-144 & EPA901.1 & EPA, 1980 & 10 & $\mathrm{pCi} / \mathrm{L}$ & $\mathrm{CN}$ \\
\hline Promethium-146 & EPA901.1 & EPA, 1980 & 20 & $\mathrm{pCi} / \mathrm{L}$ & $\mathrm{CN}$ \\
\hline Radium-226 & EPA901.1 & EPA, 1980 & 175 & $\mathrm{pCi} / \mathrm{L}$ & $\mathrm{CN}$ \\
\hline Radium-228 & EPA904.0 & EPA, 1980 & 1 & $\mathrm{pCi} / \mathrm{L}$ & $\mathrm{CN}$ \\
\hline Ruthenium-103 & EPA901.1 & EPA, 1980 & 10 & $\mathrm{pCi} / \mathrm{L}$ & $\mathrm{CN}$ \\
\hline Ruthenium-106 & EPA901.1 & EPA, 1980 & 70 & $\mathrm{pCi} / \mathrm{L}$ & $\mathrm{CN}$ \\
\hline Selenium & EPA270.2 & EPA, 1983 & 2 & $\mu g / L$ & WA \\
\hline Silver & EPA200.7 & EPA, 1983 & 0.7 & $\mu g / L$ & WA \\
\hline Sodium & EPA200.7 & EPA, 1983 & 111 & $\mu g / L$ & WA \\
\hline
\end{tabular}


(Table 3. Continued)

\begin{tabular}{|c|c|c|c|c|c|}
\hline Analyte & Method & Source & Detection Limit & Units & Lab \\
\hline Sodium-22 & EPA901.1 & EPA, 1980 & 10 & $\mathrm{pCi} / \mathrm{L}$ & $\overline{C N}$ \\
\hline Strontium-90 & EPA905.0 & EPA, 1980 & 2 & $\mathrm{pCi} / \mathrm{L}$ & $\mathrm{CN}$ \\
\hline Technetium-99 & MMEC038 & MMEC, 1992 & 300 & $\mathrm{pCi} / \mathrm{L}$ & $\mathrm{CN}$ \\
\hline Tetrachloroethylene & EPA8010 & EPA, 1986a & 1 & $\mu g / L$ & WA \\
\hline Thallium & EPA279.2 & EPA, 1983 & 2 & $\mu g / L$ & WA \\
\hline Thorium-228 & CTC0009 & CTC, 1992 & 1 & $\mathrm{pCi} / \mathrm{L}$ & $\mathrm{CN}$ \\
\hline Thorium-230 & CTC0009 & CTC, 1992 & 1 & $\mathrm{pCi} / \mathrm{L}$ & $\mathrm{CN}$ \\
\hline Thorium-232 & CTC0009 & CTC, 1992 & 1 & $\mathrm{pCi} / \mathrm{L}$ & $\mathrm{CN}$ \\
\hline Tin & EPA200.7 & EPA, 1983 & 1.9 & $\mu g / L$ & WA \\
\hline Total organic carbon & EPA415.1 & EPA, 1983 & 0.5 & $\mathrm{mg} / \mathrm{L}$ & WA \\
\hline Total organic halogens & EPA9020A & EPA, 1986a & 5 & $\mu g / L$ & WA \\
\hline Total phenols & EPA420.1 & EPA, 1983 & 5 & $\mu g / L$ & WA \\
\hline Trichloroethylene & EPA8010 & EPA, 1986a & 1 & $\mu g / L$ & WA \\
\hline Tritium & EPA906.0 & EPA, 1980 & 491.02 & $\mathrm{pC} / / \mathrm{L}$ & TM \\
\hline Uranium-234 & CTC0009 & CTC, 1992 & 1 & $\mathrm{pCi} / \mathrm{L}$ & $\mathrm{CN}$ \\
\hline Uranium-235 & CTC0009 & CTC, 1992 & 1 & $\mathrm{pC} \mathbf{i} / \mathrm{L}$ & $\mathrm{CN}$ \\
\hline Uranium-238 & СТС0009 & CTC, 1992 & 1 & $\mathrm{pCi} / \mathrm{L}$ & $\mathrm{CN}$ \\
\hline Vanadium & EPA200.7 & EPA, 1983 & 0.88 & $\mu g / L$ & WA \\
\hline Yttrium-88 & EPA901.1 & EPA, 1980 & 10 & $\mathrm{pCi} / \mathrm{L}$ & $\mathrm{CN}$ \\
\hline Zinc & EPA200.7 & EPA, 1983 & 0.35 & $\mu g / L$ & WA \\
\hline Zinc-65 & EPA901.1 & EPA, 1980 & 20 & $\mathrm{pCi} / \mathrm{L}$ & $\mathrm{CN}$ \\
\hline
\end{tabular}




\section{Sampling Locations}

FMB stream water samples were collected from three locations and seepline water samples were collected from ten locations as identified in Table 4. Figures 1 and 2 show the stream and seepline sampling locations. Background samples were collected at one stream and two seepline locations from areas upstream of the General Separations Areas (GSA). For quality assurance/quality control (QA/QC) purposes, duplicate samples were collected at locations HSP043 and FSP047 and sent to General Engineering and Environmental Physics. At locations HSP008 and FSP290, triplicate samples were collected. One sample (reference sample) was sent to General Engineering and Environmental Physics; a second was also sent as a blind sample. The third sample (split sample) was sent to Weston Analytics and Clemson Technical Center.

One trip blank sample was carried throughout sampling for each seepline area, yielding a total of two trip blank samples for the event. The trip blank samples consisted of one of each type sample container filled with deionized water. These samples were carried to each designated sampling location, handled like the collected samples, and shipped to General Engineering and Environmental Physics for analyses.

Table 4. FMC Stream and Seepline Sampling Locations

\begin{tabular}{lll} 
& \multicolumn{2}{l}{ SRS Coordinates } \\
\cline { 2 - 3 } Seepline & North & East \\
\hline FArea & & \\
FSP012 & 73602 & 49644 \\
FSP032 & 73367 & 50258 \\
FSP047 & 73609 & 50607 \\
FSP204 & 73281 & 48801 \\
FSP290 & 73160 & 46865 \\
H Area & & \\
HSP008 & 71005 & 56990 \\
HSP029 & 71278 & 56257 \\
HSP043 & 71644 & 55722 \\
HSP060 & 71629 & 55190 \\
HSP092 & 72672 & 54129 \\
Stream & & \\
FMC001F & 70350 & 57050 \\
FMC001H & 72600 & 53000 \\
FMC002H & 72200 & 43900 \\
Background* & & \\
BG001 & Seepline \\
BG002 & Seepline \\
BG003 & Stream & \\
& &
\end{tabular}

*Background locations were within the grid identified by the Site Use Grid Maps 13 and 14 as $71750 \mathrm{~N}-60000 \mathrm{~N}$ and $40000 \mathrm{E}-70000 \mathrm{E}$. 


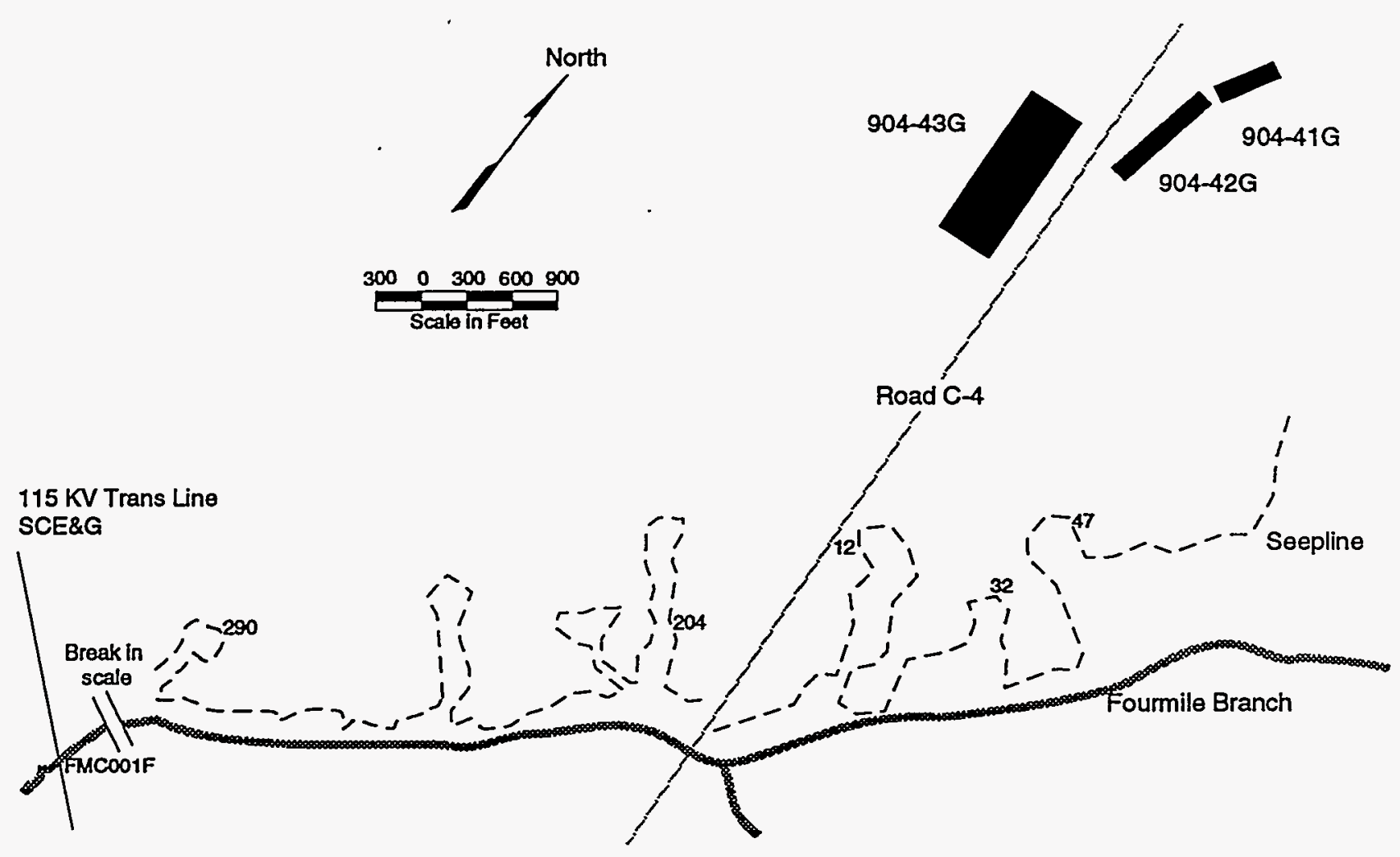

Figure 1. Location of F-Area Seepage Basins, Seepline Sampling Points (FSP), and Fourmile Branch Sampling Points

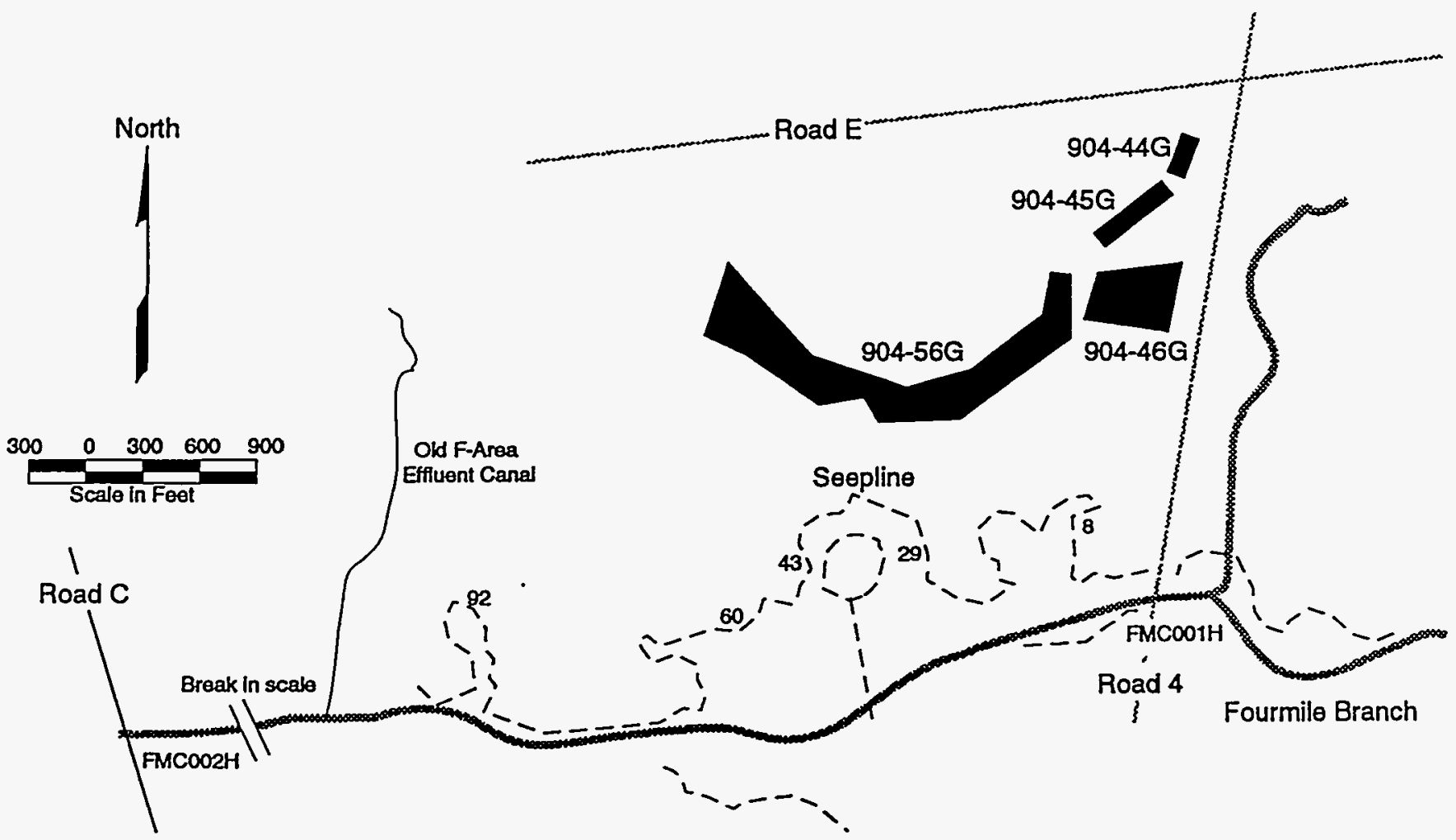

Figure 2. Location of H-Area Seepage Basins, Seepline Sampling Points (HSP), and Fourmile Branch Sampling Points 


\section{Decontamination Procedures}

All sampling equipment was decontaminated prior to the collection of each sample. The equipment was first cleaned with Milli-Q water and phosphate-free laboratory detergent (Liquinox), using a brush if necessary to remove particulate matter and surface films. The equipment was then rinsed thoroughly with Milli-Q water. Finally, the equipment was rinsed two times with pesticide-grade methanol solvent and allow to air dry. When necessary, the dry equipment was wrapped with aluminum foil to prevent contamination during storage or transport.

Decontamination rinse waters were discharged to the ground and methanol was collected in a pan and allowed to evaporate. Two samples were collected from the equipment rinsate water (QA 3 and QA 4) to evaluate the efficiency of the decontamination procedure. Two samples of the deionized water (QA 1 and QA 2) used for decontamination purposes, one from the source and one from the field carboy, were collected and sent to General Engineering and Environmental Physics for analyses.

\section{Sample Collection Procedures}

Each stream and seepline sampling location had been marked previously with PVC stakes. Identification numbers had been written on these stakes which served as the sample location ID.

\section{Seepline Water}

After locating the sampling station, a hole was excavated using a decontaminated stainless steel shovel within a three-foot radius of the PVC stake. A five-gallon plastic bucket screened on the sides and bottom was placed into the hole and covered with a lid. One bucket was set at each location, except locations HSP008, HSP043, FSP047 and FSP290 where two buckets were set side by side. The additional bucket at these locations was needed to collect sufficient water for duplicate and split samples.

The buckets were installed 24 hours prior to sample collection to allow suspended matter resulting from site preparation to settle. The time between installing the buckets and sample collection was recorded in the field notebook.

Samples for volatile organic analysis (VOA) were collected first by dipping the VOA vials directly into the buckets. These vials were completely filled so that no head space remained. All metals samples were filtered through a $0.45 \mu \mathrm{m}$ membrane disposable filter to remove fine particulate matter from the sample. This filtering was performed in the field, away from the sampling locations using porta- ble filtering equipment, within four hours of sample collection. To facilitate this, an aliquot of sufficient volume was collected from the sampling location in an unpreserved sample container and transported to the filtering location immediately following VOA collection. All apparatus used in filtering the metals samples was rinsed and flushed thoroughly with deionized water after processing each sample.

Using a peristaltic pump powered by a 12 -volt battery and silastic (silicone) tubing, water was pumped from the bucket to the remaining sample containers. New tubing was used for each sampling location and was flushed for 20 seconds with water from the bucket prior to sample collection.

\section{Stream Water Sampling}

Collection of stream water samples was performed by dipping the sample container directly into the stream. This collection method minimized alteration of the sample as well as the potential for sample cross-contamination through the use of poorly decontaminated sampling equipment.

Surface grab samples were collected in the middle of the stream from the top of the water column. The container was placed into the water with the mouth of the container facing upstream so that water flowed directly into the container. Care was taken when opening and filling the bottles to prevent the loss of any preservatives.

All containers, except the VOA vials, were filled to the shoulder with water. VOA vials were filled completely, with no head space remaining. Filtering procedures for metals samples were the same as for the seepline water samples.

\section{Sample Processing}

Once all sample containers had been filled for a sampling location, they were stored in a cooler containing blue ice for transport to the staging area. Prior to transporting the samples, they were delivered to the Health Protection Department where container exteriors were scanned for radioactivity. The purpose of this scan was to identify any radiological health hazards associated with handling the samples. At the staging area, the samples were placed in a refrigerator and stored at $4^{\circ} \mathrm{C}$ until they were packaged for shipping. Samples were packed and shipped to analytical subcontractors according to the procedures "Packaging Non-radioactive Water Samples for Off-Site Shipment" and "Packaging Radioactive Water Samples for Off-Site Shipment" (WSRC-3Q5, Ch. 12). The particular proce- 
dure used was determined by the total activity results provided by EMS. Chain of custody procedures were followed at all times for all samples. Copies of the completed chain of custody forms for each sampling location have been presented by Metcalf and Eddy (1992).
The $\mathrm{pH}$ and conductivity of the water at each sampling location was measured in situ at the time of sampling and recorded in the field notebook. The probes were rinsed with deionized water between each sampling location. 
WSRC-TR-93-289 


\section{Discussion}

Concentrations of constituents measured at seepline sampling locations are expected to fluctuate throughout the year. Climate, especially rainfall, influences measured concentrations. Low rainfall amounts for a few months prior to sampling could concentrate constituents, and high rainfall amounts could dilute the constituents in the shallow groundwater at the seepline intercept. Rainfall amounts measured at the F-Area weather station from January through July 1992 totaled $75.23 \mathrm{~cm}$. The average rainfall from 1960 to 1991 for the weather station in F Area through the month of July was $78.91 \mathrm{~cm}$. This indicates for the July 1992 sampling event, rainfall amounts in $\mathrm{F}$ and $\mathrm{H}$ Areas were near normal. This should be considered when interpreting the results.

Analytical services were provided by several laboratories. General Engineering (nonradiological analyses) and Environmental Physics (radiological analyses) were used as the primary laboratories. Weston Analytics (nonradiological analyses) and Clemson Technical Center (radiological analyses) were used for split sample analyses. For this report, samples analyzed by General Engineering, Environmental Physics, and their subcontractors were considered to be the reference samples on which all analyses and interpretation was based. Samples analyzed by Weston Analytics, Clemson Technical Center, and their subcontractors were considered to be quality assurance samples and were not used in any analyses or interpretations. This should prevent inter-lab variability of constituent concentrations from biasing any analyses and interpretations. Environmental Physics subcontracted ${ }^{129} \mathrm{I}$ and ${ }^{237} \mathrm{~Np}$ analyses to Teledyne Isotopes, Inc. for the reference samples and Weston Analytics subcontracted gross alpha, nonvolatile beta, and tritium analyses to TMA/Eberline, Inc. for the split samples.

Analytical results for the July 1992 sampling event of the semi-annual sampling program along FMB and its seeplines are presented in Analytical Results (page 32). The results are presented in a format similar to that used in the quarterly groundwater monitoring reports issued by EMS (EMS 1992). For each sampling location (seepline and stream), sampling date, field measurements including depth to water, $\mathrm{pH}$, and specific conductance, and all laboratory analyses are presented (excluding lab blanks and standards). Included in the laboratory analyses table for each analyte is the lab that performed the analyses, any analytical modifiers, the analytical result, the accuracy of the result (detected radiological parameters only), any established standard (PDWS, MCL, SDWS), any 1989 analytical results for that analyte and location, and the units the results are reported in. At the beginning of Ana- lytical Results (page 32), a legend provides explanations for the abbreviations and modifiers used to present the data. For locations where split samples were collected, results from each lab are presented for each analyte. Laboratory duplicates were averaged with their corresponding reference sample for both presentation in Analytical Results and analysis purposes and blind duplicate samples analyzed by General Engineering and Environmental Physics were also averaged with their corresponding reference samples for analysis.

Analytical results from the trip blank (QA 2S, QA 4S) and the other quality assurance samples (QA 1, QA 2, QA 3, and QA 4) are also presented in Analytical Results. Both trip blank samples exhibit elevated sodium concentrations attributed to the deionizing system from which the water used in the samples was obtained. Independent analyses have confirmed that sodium concentrations in the water from the system are elevated. Water from this system was used only in the trip blank samples; therefore, the elevated sodium concentrations characteristic of the water from this system will have no impact on any other analytical results for this project.

\section{Stream and Seepline Water Conductivity and $\mathrm{pH}$}

Conductivity and $\mathrm{pH}$ are often used as indicator parameters of overall water quality and can aide the researcher in the overall assessment of the contamination of a site. Conductivity has been particularly useful in delineating areas exhibiting high ion concentrations. The extensive study of pH, conductivity, and tritium in 1989 (Haselow et al. 1990) showed that the seepline water in both $F$ and $H$ Areas exhibited low $\mathrm{pH}$ and high conductivity. Since 1989 , quarterly surveys of $\mathrm{pH}$, conductivity, and tritium (Dixon and Rogers 1991a and b) have shown that these parameters have been trending towards more normal ranges. The $\mathrm{pH}$ of the F-Area and $\mathrm{H}$-Area seepline water in July 1992 ranged from $4.10-5.38$ and $4.80-6.32$, respectively. The conductivity of the F-Area and H-Area seepline water ranged from $88-277 \mu \mathrm{S} / \mathrm{cm}$ and $33-237$ $\mu \mathrm{S} / \mathrm{cm}$, respectively. The $\mathrm{pH}$ and conductivity of the FMB stream water in July 1992 ranged from $6.67-7.19$ and 70 $94 \mu \mathrm{S} / \mathrm{cm}$. The seepline $\mathrm{pH}$ values appear to be near normal ranges, while the conductivity values suggest that some locations are being influenced by elevated concentrations of ions. This is substantiated by the fact that locations exhibiting high conductivity values also exhibit high concentrations of ions, particularly aluminum, calcium, iron, magnesium, and sodium. FMB $\mathrm{pH}$ values appear to be near normal. Conductivity values in FMB are elevated somewhat over background as a result of ion contribution from the F- and H-Area seeps (particularly calcium and sodium). 
Comparison of Seepline Locations to Background Locations

Data used in this comparison consisted of the contaminant concentration results from all seepline and background sampling locations. The data was analyzed to determine if contaminant concentrations along the seepline were significantly greater than concentrations of the same contaminant in background samples.

Frequently, the data were reported by the laboratory as below the limit of detection (LOD). Analytical results calculated to be less than the LOD are not considered reliable and therefore are reported as the LOD value. Such data are said to be left censored. Common practice is to include these data in subsequent statistical analyses as LOD/2, which was the method chosen for this comparison.

Contaminants were selected for statistical analysis only when $50 \%$ or more of the data in the background or other seepline areas were greater than the LOD. Also, when both background samples were reported as LOD for a particular analyte, no statistical analysis was performed.

The data for background samples and the two seepline areas (FSP and HSP) were plotted and examined. When these data collectively spanned one or more orders of magnitude, a natural log transformation was performed. Subsequently, a one-way ANOVA was performed on the log-transformed data. The method of single degree of freedom contrasts (Steel and Torrie 1980) was used to compare the background mean to each of the two seepline area means. Ranks of the concentration data were also computed and the same parametric statistical methods were performed again using these ranks, instead of the concentration data (Conover 1980). The latter analysis was corroborative of the former.

Significance probabilities, or p-values, obtained from each of the single degree of freedom contrasts were examined and compared to the standard Type I error rate criterion of $5 \%$ (i.e., 0.05). However, since these tests were performed on approximately 20 different chemical constituents measured from the same water samples, a potential for Type I exror inflation exists. To protect against such inflation, the Bonferroni multiple comparison method (Miller 1981) was also used. Instead of declaring contrasts among the two pairs of seepline means (BG-FSP or BG-HSP) to be significant at the 0.05 level, they were declared significant if their $\mathrm{p}$-values were less than or equal to $0.05 / 20$ or 0.0025 .

Plots of the natural logs of the constituent concentrations were examined; in most instances, the log transformation apparently preserved the assumption of equal variances among treatment groups. However, when the within-group variation appeared disparate between groups, a Levene's test for variance homogeneity (Levene 1960) was performed. When this statistical test was significant, a Welch's test of the equality of means (Welch 1951) was also performed to corroborate the results of the one-way ANOVA with single degree of freedom contrasts among log-transformed means.

Table 5 shows the probabilities resulting from both statistical tests and Table 6 gives the mean and range of concentration for each analyte used in the statistical tests. Plots of the analyte concentrations as a function of seepline area (i.e., BG, FSP, HSP) are given in Appendix B. These plots should provide the reader with a view of the variability associated with each analyte on which statistical analysis was performed.

FMB stream samples were not compared to background using the above-mentioned statistical techniques, since there was only one background stream sample. 
Table 5. Comparison of FSP and HSP Sampling Locations to Background Locations

\begin{tabular}{llcccc} 
& & \multicolumn{2}{c}{ Natural Log Transform Contrasts } & \multicolumn{2}{c}{ Ranked Sum Averaged Contrasts } \\
\cline { 3 - 6 } Analyte & & BG-FSP & BG-HSP & BG-FSP & BG-HSP \\
\hline Alkalinity & Prob $>$ It & 0.1768 & 0.1249 & 0.0537 & 0.0332 \\
Aluminum & Prob $>$ It & 0.2671 & 0.0135 & 0.1349 & 0.0143 \\
Barium & Prob $>$ It & 0.0071 & 0.1628 & 0.0030 & 0.1249 \\
Calcium & Prob $>$ It & 0.1000 & 0.1436 & 0.0488 & 0.0549 \\
Chloride & Prob $>$ It & $*-$ & - & 0.1198 & 0.1336 \\
Gross alpha & Prob $>$ It & 0.9927 & 0.9900 & 0.9062 & 0.8139 \\
Hardness & Prob $>$ It & - & - & 0.6410 & 0.3162 \\
Lead & Prob $>$ It & 0.8538 & 0.3586 & 0.7124 & 0.4242 \\
Magnesium & Prob $>$ It & 0.0607 & 0.3040 & 0.0838 & 0.3082 \\
Manganese & Prob $>$ It & 0.0590 & 0.2012 & 0.0422 & 0.1293 \\
Mercury & Prob $>$ It & 0.4698 & 0.8353 & 0.4844 & 0.8873 \\
Nitrate as nitrogen & Prob $>$ It & 0.3454 & 0.2917 & 0.1336 & 0.1198 \\
Nonvolatile beta & Prob $>$ It & 0.1099 & 0.1283 & 0.1061 & 0.1475 \\
Potassium & Prob $>$ It & 0.3587 & 0.5626 & 0.3366 & 0.4869 \\
Radium-226 & Prob $>$ It & 0.9564 & 0.0515 & 0.8048 & 0.0958 \\
Radium-228 & Prob $>$ It & 0.6047 & 0.5570 & 0.5730 & 0.8811 \\
Sodium & Prob $>$ It & 0.0851 & 0.0078 & 0.0655 & 0.0045 \\
Strontium-90 & Prob $>$ It & 0.2412 & 0.3803 & 0.2203 & 0.3999 \\
Total Organic Carbon & Prob $>$ It & 0.7147 & 0.6730 & 0.6673 & 0.3812 \\
Total Organic Halogens & Prob $>$ It & 0.9609 & 0.4233 & 0.9019 & 0.7077 \\
Tritium & Prob $>$ It & 0.0174 & 0.0000 & 0.0604 & 0.0025 \\
Zinc & Prob $>$ It & 0.4661 & 0.5202 & 0.3809 & 0.6317
\end{tabular}

*Natural log transform was not performed since data range was less than one order of magnitude.

Table 6. List of Mean Concentrations and Ranges for Analytes Used in Statistical Analysis

\begin{tabular}{lcccc} 
Analyte & Seepline & Units & Mean & Range \\
\hline Alkalinity & BG & $\mathrm{mg} / \mathrm{L}$ & 1.43 & $1.43-1.43$ \\
& FSP & & 11.23 & $1.55-26.0$ \\
& HSP & & 16.31 & $1.5-42.5$ \\
Aluminum & & & \\
& BG & $\mu \mathrm{g} / \mathrm{L}$ & 215.5 & $175-256$ \\
& FSP & & 619.70 & $224-936$ \\
Barium & HSP & & 4449.80 & $606-11515$ \\
& & & & \\
& BG & $\mu g / L$ & 16.50 & $12.2-20.8$ \\
Calcium & FSP & & 83.67 & $33.45-101.5$ \\
& HSP & & 34.76 & $17.8-68.7$ \\
& & & & $262-487$ \\
& BG & $\mu g / L$ & 374.50 & $491-5720$ \\
& FSP & & 1909.40 & $747-1820$
\end{tabular}


(Table 6. Continued)

\begin{tabular}{|c|c|c|c|c|}
\hline Analyte & Seepline & Units & Mean & Range \\
\hline \multirow[t]{3}{*}{ Chloride } & BG & $\mathrm{mg} / \mathrm{L}$ & 2.41 & $1.85-2.98$ \\
\hline & FSP & & 3.99 & $2.43-6.52$ \\
\hline & HSP & & 3.93 & $2.38-6.05$ \\
\hline \multirow[t]{3}{*}{ Gross alpha } & BG & $\mathrm{pCi} / \mathrm{L}$ & 3.70 & $2.5-4.9$ \\
\hline & FSP & & 4.66 & $1.0-10.2$ \\
\hline & HSP & & 7.54 & $1.0-19.0$ \\
\hline \multirow[t]{3}{*}{ Hardness } & BG & $\mathrm{mg} / \mathrm{L}$ & 15.25 & $8.5-22.0$ \\
\hline & FSP & & 12.57 & $7.79-25.0$ \\
\hline & HSP & & 9.26 & $2.8-19.5$ \\
\hline \multirow[t]{3}{*}{ Lead } & BG & $\mu g / L$ & 2.33 & $1.50-3.16$ \\
\hline & FSP & & 2.28 & $1.5-5.45$ \\
\hline & HSP & & 5.07 & $1.5-8.68$ \\
\hline \multirow[t]{3}{*}{ Magnesium } & BG & $\mu \mathrm{g} / \mathrm{L}$ & 425.50 & $349-502$ \\
\hline & FSP & & 1934.00 & $485-4770$ \\
\hline & HSP & & 928.60 & $379-1830$ \\
\hline \multirow[t]{3}{*}{ Manganese } & BG & $\mu g / L$ & 30.17 & $18.4-41.95$ \\
\hline & FSP & & 1157.22 & $49.6-2560$ \\
\hline & HSP & & 211.91 & $28.5-527$ \\
\hline \multirow[t]{3}{*}{ Mercury } & BG & $\mu g / L$ & 0.42 & $0.37-0.47$ \\
\hline & FSP & & 0.27 & $0.1-0.47$ \\
\hline & HSP & & 0.77 & $0.1-1.9$ \\
\hline \multirow[t]{3}{*}{ Nitrate as nitrogen } & BG & $\mathrm{mg} / \mathrm{L}$ & 0.24 & $0.23-0.26$ \\
\hline & FSP & 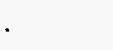 & 8.55 & $0.27-32.2$ \\
\hline & HSP & & 7.49 & $0.02-20.05$ \\
\hline \multirow[t]{3}{*}{ Nonvolatile beta } & BG & $\mathrm{pCi} / \mathrm{L}$ & 3.35 & $2.1-4.6$ \\
\hline & FSP & & 129.89 & $2.15-354.5$ \\
\hline & HSP & & 240.58 & $3.0-1070.0$ \\
\hline \multirow[t]{3}{*}{ Potassium } & BG & $\mu g / L$ & 460.50 & $250-671$ \\
\hline & FSP & & 1504.00 & $250-3960$ \\
\hline & HSP & & 744.50 & $250-1110$ \\
\hline \multirow[t]{3}{*}{ Radium-226 } & $\mathbf{B G}$ & $\mathrm{pCi} / \mathrm{L}$ & 0.88 & $0.5-1.26$ \\
\hline & FSP & & 0.99 & $0.5-1.75$ \\
\hline & HSP & & 3.37 & $1.17-5.46$ \\
\hline
\end{tabular}


(Table 6. Continued)

\begin{tabular}{|c|c|c|c|c|}
\hline Analyte & Seepline & Units & Mean & Range \\
\hline \multirow[t]{3}{*}{ Radium-228 } & BG & $\mathrm{pCi} / \mathrm{L}$ & 4.98 & $4.73-5.23$ \\
\hline & FSP & & 25.93 & $1.88-90.6$ \\
\hline & HSP & & 136.51 & $1.17-523$ \\
\hline \multirow[t]{3}{*}{ Sodium } & BG & $\mu g / L$ & 1027 & $794-1260$ \\
\hline & FSP & & 8658.00 & $2440-27000$ \\
\hline & HSP & & 31310.00 & $2850-59100$ \\
\hline \multirow[t]{3}{*}{ Strontium-90 } & BG & $\mathrm{pCi} / \mathrm{L}$ & 2.43 & $1.0-3.86$ \\
\hline & FSP & & 43.08 & $1.0-124.0$ \\
\hline & HSP & & 118.31 & $1.0-549$ \\
\hline \multirow[t]{3}{*}{ Total Organic Carbon } & BG & $\mathrm{mg} / \mathrm{L}$ & 14.00 & $7.0-21.0$ \\
\hline & FSP & & 23.10 & $3.0-50.0$ \\
\hline & HSP & & 5.28 & $2.6-7.9$ \\
\hline \multirow[t]{3}{*}{ Total Organic Halogens } & BG & $\mu g / L$ & 17.15 & $9.2-21.5$ \\
\hline & FSP & & 22.33 & $2.5-51.4$ \\
\hline & HSP & & 16.37 & $2.5-32.5$ \\
\hline \multirow[t]{3}{*}{ Tritium } & BG & $\mathrm{pCi} / \mathrm{ml}$ & 6.50 & $4.86-8.15$ \\
\hline & FSP & & 440.31 & $28.9-1290.0$ \\
\hline & HSP & & 2646.70 & $305.5-5320$ \\
\hline \multirow[t]{3}{*}{ Zinc } & BG & $\mu g / L$ & 119.10 & $95.2-143.0$ \\
\hline & FSP & & 97.16 & $57.8-140.0$ \\
\hline & HSP & & 149.86 & $77.3-199.0$ \\
\hline
\end{tabular}


Using the natural $\log$ transform, the following analytes exhibited concentrations significantly greater than background at the Type 1 error rate of 0.05 :

\begin{tabular}{cl} 
Area & Analytes \\
\hline $\mathrm{F}$ & barium, ${ }^{3} \mathrm{H}$ \\
$\mathrm{H}$ & aluminum, sodium, ${ }^{3} \mathrm{H}$
\end{tabular}

Using the ranks of the concentration data, the following analytes exhibited concentrations significantly greater than background at a Type 1 error rate of 0.05 :

\begin{tabular}{cc} 
Area & Analytes \\
\hline $\mathrm{F}$ & alkalinity, barium, calcium, manganese \\
$\mathrm{H}$ & alkalinity, aluminum, calcium, sodium, ${ }^{3} \mathrm{H},{ }^{226} \mathrm{Ra}$
\end{tabular}

Using the Bonferroni multiple comparison Type 1 error rate of 0.0025 , the only analyte exhibiting concentrations significantly greater than background for either the transformed or ranked data was tritium at the H-Area seepline.
Aluminum, barium, calcium, magnesium, manganese, and potassium are likely being leached from the soil profile by low pH water as suggested by Looney et al. (1989) and Haselow et al. (1990). Observation of the data suggests that the concentrations of these constituents has decreased at most locations for which 1989 measurements are available for comparison. This can probably be attributed to the increase in $\mathrm{pH}$ of the seepline water in general since 1989 (Dixon and Rogers 1992a and b). An increase in pH (to about neutral) will reduce the solubility of these metals and their concentrations in the seepwater. Data from 1989 for barium were not available for comparison; however, most F-Area seepline locations exhibited slightly elevated barium concentrations. The maximum concentration of barium measured at the F-Area seepline was $101.5 \mathrm{mg} / \mathrm{L}$, well below the MCL of $2000 \mathrm{mg} / \mathrm{L}$. Barium concentrations in $\mathrm{H}$ Area did not appear to be elevated above background levels. Although tritium appears to be impacting both seeplines and sodium appears to be impacting the HArea seepline, the general trend, when compared to 1989 concentrations, is towards decline. The decline in tritium concentrations at both seeplines has been documented by Dixon and Rogers (1992a and b). 
Comparison of Stream and Seepline Locations to Established Standards

In conjunction with the statistical tests, analysis and interpretation of the data was also performed based on observed trends. A list of those analytes occurring above LOD without any other analytical modifier (except V) is given in Table 7. Analytes with occurrences greater than their LOD totaled 42 of 74 and represented 56.8 percent of the total analyte list.

A list of the analytes, along with the corresponding sampling locations where concentrations were at levels greater than those established by the PDWS or MCL lists, is given in Table 8. Seven analytes were found to be above these standards at one or more sampling locations (stream or seepline). They included gross alpha, nonvolatile beta, ${ }^{129} \mathrm{I},{ }^{228} \mathrm{Ra},{ }^{90} \mathrm{Sr}$, and ${ }^{3} \mathrm{H}$. Of these six analytes, five were detected at levels greater than the PDWS or MCL in 1989 (Haselow et al. 1990). In $1989,{ }^{228} \mathrm{Ra}$ analysis was not performed.

Analytes elevated above the PDWS or MCL at one or more sampling locations included:

\begin{tabular}{ccl} 
Date & Area & \multicolumn{1}{c}{ Analytes } \\
\hline $7 / 92$ & $\mathrm{~F}$ & $\begin{array}{l}\text { nitrate, nonvolatile beta, }{ }^{3} \mathrm{H},{ }^{129} \mathrm{I},{ }^{228} \mathrm{Ra}, \\
\end{array}$ \\
& ${ }^{90} \mathrm{Sr}$ \\
& $\begin{array}{l}\text { cadmium, nitrate, gross alpha, nonvolatile } \\
\text { beta, }{ }^{249} \mathrm{Am},{ }^{129} \mathrm{I},{ }^{3} \mathrm{H},{ }^{226} \mathrm{Ra},{ }^{89} \mathrm{Sr},{ }^{90} \mathrm{Sr}, \\
\end{array}$ \\
&
\end{tabular}

$7 / 92$

H nitrate, gross alpha, nonvolatile beta, ${ }^{3} \mathrm{H}$, ${ }^{129} \mathrm{I},{ }^{228} \mathrm{Ra},{ }^{90} \mathrm{Sr}$

1989

$7 / 92$

FMB nonvolatile beta, ${ }^{3} \mathrm{H},{ }^{129} \mathrm{~L},{ }^{228} \mathrm{Ra},{ }^{90} \mathrm{Sr}$

1989
A list of the analytes, along with the corresponding sampling locations where concentrations were at levels greater than those established by the SDWS, is given in Table 9 . Two analytes were found to be above the SDWS at one or more seepline and stream sampling locations: iron and manganese. Iron and manganese were also elevated above the SDWS at the background stream location. They were also elevated above the SDWS at one or more seepline location in 1989. As pointed out by Haselow et al. (1990), SDWS for iron and manganese were established to minimize staining from rust spots. Aluminum, calcium, magnesium, potassium and sodium appear to be elevated at both the F-and H-Area seeplines; however, no standards such as the PDWS, SDWS, or MCL exist for comparison. 
Table 7. Analytes Reported at Concentrations Greater Than Their Method Detection Limit

\begin{tabular}{ll} 
Analyte & Analyte \\
\hline Alkalinity & Nickel \\
Aluminum & Nitrate as nitrogen \\
Ammonia nitrogen & nonvolatile beta \\
Arsenic & Plutonium-238 \\
Barium & Potassium \\
Calcium & Radium-226 \\
Cesium-137 & Radium-228 \\
Chloride & Sodium \\
Chloroform & Strontium-90 \\
Chromium & Thorium-230 \\
Cobalt-60 & Thorium-232 \\
Copper & Tin \\
Fluoride & Total organic carbon \\
Gross alpha & Total organic halogens \\
Hardness & Total phenols \\
Iodine-129 & Tritium \\
Iron & Uranium-234 \\
Lead & Uranium-238 \\
Magnesium & Vanadium \\
Manganese & Zinc \\
Mercury & \\
\hline
\end{tabular}

Table 8. Analytes and Corresponding Sampling Locations Where July 1992 Concentrations Exceeded Either the PDWS or MCL

\begin{tabular}{|c|c|c|c|c|c|c|c|}
\hline Analyte & Lab & $\operatorname{Mod}^{*}$ & 7/92 Result & $A \infty * *$ & Standard & Units & Location \\
\hline Gross alpha & GE & & 19 & 13 & 15 & $\mathrm{pCi} / \mathrm{L}$ & HSP008. \\
\hline Iodine-129 & TE & & 2.8 & 1.3 & 1 & $\mathrm{pCi} / \mathrm{L}$ & FMC001F \\
\hline Iodine-129 & $\mathrm{TE}$ & & 4.2 & 1.3 & 1 & $\mathrm{pCi} / \mathrm{L}$ & FSP012 \\
\hline Iodine- 129 & TE & & 2.8 & 1.5 & 1 & $\mathrm{pCi} / \mathrm{L}$ & FSP032 \\
\hline Iodine- 129 & $\mathrm{TE}$ & & 41.4 & 5.7 & 1 & $\mathrm{pCi} / \mathrm{L}$ & FSP204 \\
\hline Iodine- 129 & TE & & 14.6 & 2.1 & 1 & $\mathrm{pCi} / \mathrm{L}$ & HSP008 \\
\hline Iodine-129 & $\mathrm{TE}$ & & 7.8 & 1.2 & 1 & $\mathrm{pCi} / \mathrm{L}$ & HSP029 \\
\hline Iodine-129 & $\mathrm{TE}$ & & 52.2 & 3.1 & 1 & $\mathrm{pCi} / \mathrm{L}$ & HSP043 \\
\hline Nitrate as nitrogen & GE & & 32.2 & & 10 & $\mathrm{mg} / \mathrm{L}$ & FSP204 \\
\hline Nitrate as nitrogen & GE & & 20.05 & & 10 & $\mathrm{mg} / \mathrm{L}$ & HSP008 \\
\hline Nitrate as nitrogen & GE & & 12.2 & & 10 & $\mathrm{mg} / \mathrm{L}$ & HSP029 \\
\hline Nonvolatile beta & $\mathrm{GE}$ & V & 65.5 & 4.5 & 50 & $\mathrm{pCi} / \mathrm{L}$ & FMCOOIH \\
\hline Nonvolatile beta & GE & & 75.6 & 4.8 & 50 & $\mathrm{pCi} / \mathrm{L}$ & FSP012 \\
\hline Nonvolatile beta & GE & & 168 & 7 & 50 & $\mathrm{pCi} / \mathrm{L}$ & FSP032 \\
\hline Nonvolatile beta & GE & & 354.5 & 9.3 & 50 & $\mathrm{pCi} / \mathrm{L}$ & FSP204 \\
\hline Nonvolatile beta & GE & & 56.4 & 9 & 50 & $\mathrm{pCi} / \mathrm{L}$ & HSP008 \\
\hline Nonvolatile beta & GE & V & 1070 & 18 & 50 & $\mathrm{pCi} / \mathrm{L}$ & HSP029 \\
\hline Radium-228 & GP & & 16.5 & 1.4 & 7.85 & $\mathrm{pCi} / \mathrm{L}$ & FMC001F \\
\hline Radium-228 & GP & & 11.4 & 1.2 & 7.85 & $\mathrm{pCi} / \mathrm{L}$ & $\mathrm{FMCOO2H}$ \\
\hline Radium-228 & GP & & 14 & 2.7 & 7.85 & $\mathrm{pC} / / \mathrm{L}$ & FSP012 \\
\hline Radium-228 & GP & & 10.6 & 1.1 & 7.85 & $\mathrm{pCi} / \mathrm{L}$ & FSP032 \\
\hline Radium-228 & GP & & 12.6 & 1.6 & 7.85 & $\mathrm{pCi} / \mathrm{L}$ & FSP047 \\
\hline
\end{tabular}


(Table 8. Continued)

\begin{tabular}{|c|c|c|c|c|c|c|c|}
\hline Analyte & Lab & Mod* & 7/92 Result & $A C c^{* *}$ & Standard & Units & Location \\
\hline Radium-228 & GP & & 90.6 & 3.6 & 7.85 & $\mathrm{pCi} / \mathrm{L}$ & FSP204 \\
\hline Radium-228 & GP & & 523 & 7.4 & 7.85 & $\mathrm{pCi} / \mathrm{L}$ & HSPO29 \\
\hline Radium-228 & GP & & 153 & 3.6 & 7.85 & $\mathrm{pCi} / \mathrm{L}$ & HSP060 \\
\hline Strontium-90 & GP & & 27.9 & 3.7 & 8 & $\mathrm{pCi} / \mathrm{L}$ & FMC001F \\
\hline Strontium-90 & GP & & 12.4 & 2.7 & 8 & $\mathrm{pCi} / \mathrm{L}$ & $\mathrm{FMC001H}$ \\
\hline Strontium-90 & GP & & 16.7 & 1.9 & 8 & $\mathrm{pCi} / \mathrm{L}$ & $\mathrm{FMCOO2H}$ \\
\hline Strontium-90 & GP & & 22.7 & 2 & 8 & $\mathrm{pCi} / \mathrm{L}$ & FSP012 \\
\hline Strontium-90 & GP & & 124 & 4 & 8 & $\mathrm{pCi} / \mathrm{L}$ & FSP032 \\
\hline Strontium-90 & GP & & 18.5 & 2.45 & 8 & $\mathrm{pCi} / \mathrm{L}$ & FSP047 \\
\hline Strontium-90 & GP & & 49.2 & 3 & 8 & $\mathrm{pCi} / \mathrm{L}$ & FSP204 \\
\hline Strontium-90 & $G P$ & & 549 & 8.4 & 8 & $\mathrm{pC} / \Omega$ & HSP029 \\
\hline Strontium-90 & GP & & 33.8 & 3.6 & 8 & $\mathrm{pCi} / \mathrm{L}$ & HSPO60 \\
\hline Tritium & $\mathrm{GE}$ & & 640 & 3.8 & 20 & $\mathrm{pCi} / \mathrm{ml}$ & $\mathrm{FMCOO1F}$ \\
\hline Tritium & GE & & 72.8 & 1.3 & 20 & $\mathrm{pCi} / \mathrm{ml}$ & $\mathrm{FMCOO1H}$ \\
\hline Tritium & $\mathbf{G E}$ & & 170 & 2 & 20 & $\mathrm{pCi} / \mathrm{ml}$ & $\mathrm{FMCOO2H}$ \\
\hline Tritium & $G E$ & & 28.9 & 1 & 20 & $\mathrm{pCi} / \mathrm{ml}$ & FSP012 \\
\hline Tritium & $\mathrm{GE}$ & & 730 & 4 & 20 & $\mathrm{pCi} / \mathrm{ml}$ & FSP032 \\
\hline Tritium & GE & & 94.2 & 1.6 & 20 & $\mathrm{pCi} / \mathrm{ml}$ & FSP047 \\
\hline Tritium & GE & & 1290 & 5.6 & 20 & $\mathrm{pCi} / \mathrm{ml}$ & FSP204 \\
\hline Tritium & GE & & 58.45 & 1.33 & 20 & $\mathrm{pCi} / \mathrm{ml}$ & FSP290 \\
\hline Tritium & GE & & 5320 & 10.5 & 20 & $\mathrm{pCi} / \mathrm{ml}$ & HSPO08 \\
\hline Tritium & GE & & 858 & 4.4 & 20 & $\mathrm{pCi} / \mathrm{ml}$ & HSP029 \\
\hline Tritium & GE & & 3260 & 8.4 & 20 & $\mathrm{pCi} / \mathrm{ml}$ & HSP043 \\
\hline Tritium & $\mathrm{GE}$ & & 3490 & 11 & 20 & $\mathrm{pCi} / \mathrm{ml}$ & HSP060 \\
\hline Tritium & GE & & 305.5 & 2.8 & 20 & $\mathrm{pCi} / \mathrm{ml}$ & HSP092 \\
\hline
\end{tabular}

*Analytical Modifier (See Table 14)

**Accuracy

Table 9. Analytes and Corresponding Sampling Locations Where July 1992 Concentrations Exceeded the SDWS

\begin{tabular}{|c|c|c|c|c|c|c|}
\hline Analyte & Lab & $\operatorname{Mod}^{*}$ & 7/92 Result & Standard & Units & Location \\
\hline Iron & $\overline{G E}$ & & 843 & 300 & $\mu g / L$ & BG003 \\
\hline Iron & GE & & 392 & 300 & $\mu g / L$ & FMCOOIF \\
\hline Iron & GE & & 349 & 300 & $\mu g / L$ & $\mathrm{FMC001H}$ \\
\hline Iron & GE & & 919.5 & 300 & $\mu g / L$ & $\mathrm{FMCOO2H}$ \\
\hline Iron & GE & & 7140 & 300 & $\mu g / L$ & FSP012 \\
\hline Iron & GE & & 12000 & 300 & $\mu g / L$ & FSP047 \\
\hline Iron & GE & & 698 & 300 & $\mu g / L$ & FSP204 \\
\hline Iron & GE & & 3105 & 300 & $\mu g / L$ & HSP008 \\
\hline Iron & GE & & 1920 & 300 & $\mu g / L$ & HSPO43 \\
\hline Iron & GE & & 2810 & 300 & $\mu g / L$ & HSPO60 \\
\hline
\end{tabular}


(Table 9. Continued)

\begin{tabular}{|c|c|c|c|c|c|c|}
\hline Analyte & Lab & Mod* & 7/92 Result & Standard & Units & Location \\
\hline Iron & $\overline{G E}$ & & 2880 & 300 & $\mu g / L$ & HSP092 \\
\hline Manganese & GE & & 223 & 50 & $\mu g / L$ & BG003 \\
\hline Manganese & GE & & 65.3 & 50 & $\mu g / L$ & $\mathrm{FMCOO1H}$ \\
\hline Manganese & GE & & 704 & 50 & $\mu g / L$ & $\mathrm{FMCOO2H}$ \\
\hline Manganese & GE & & 862 & 50 & $\mu g / L$ & FSP047 \\
\hline Manganese & $\mathrm{GE}$ & & 2560 & 50 & $\mu g / L$ & FSP204 \\
\hline Manganese & GE & & 91.05 & 50 & $\mu g / L$ & HSP008 \\
\hline Manganese & GE & & 527 & 50 & $\mu g / L$ & HSP029 \\
\hline Manganese & $G E$ & & 206 & 50 & $\mu g / L$ & HSPO60 \\
\hline Manganese & GE & & 207 & 50 & $\mu g / L$ & HSP092 \\
\hline
\end{tabular}

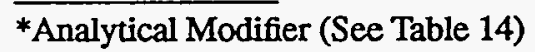


Comparison of 1989 and July 1992 Stream and Seepline Locations

Some of the locations sampled in July 1992 were also sampled in 1989. These locations are given in Table 10. To facilitate comparison, data from 1989 are presented with the July 1992 data for coinciding sampling locations (Analytical Results, page 32). A list of analytes along with the corresponding sampling locations where the July 1992 concentrations were greater than those measured at the same locations in 1989 is given in Table 11. A total of 11 different analytes were measured at concentrations greater than those measured in $\mathbf{1 9 8 9}$ at the same locations.

Analytes where July 1992 concentrations exceeded those measured in 1989 at one or more sampling location included:

\begin{tabular}{cl} 
Area & \multicolumn{1}{c}{ Analytes } \\
\hline F & aluminum, chloride, mercury, ${ }^{129} \mathrm{I}$ \\
$\mathrm{H}$ & $\begin{array}{l}\text { aluminum, chloride, mercury, lead, sodium, zinc, } \\
{ }^{129} \mathrm{I}\end{array}$ \\
$\mathrm{FMB}$ & ${ }^{\text {alkalinity, chloride, mercury, sodium, zinc, }{ }^{137} \mathrm{Cs},} \mathrm{Ra},{ }^{90} \mathrm{Sr}$
\end{tabular}

It appears from this information that mercury may be influencing the seepline water in both $\mathrm{F}$ and $\mathrm{H}$ Areas as well as in FMB; however, closer examination of the data leads one to conclude otherwise. Mercury concentrations at all F-Area seepline locations and at the FMB stream locations are within range of the background concentrations measured upstream of $\mathrm{F}$ and $\mathrm{H}$ Area. In $\mathrm{H}$ Area, three of five seepline locations exhibit elevated mercury concentrations. The highest concentration of mercury measured (but slightly less than the MCL) was at location HSP008, which lies in a previously delineated mercury plume migrating from the H-Area basins (Nixon et al. 1991).

As mentioned earlier, at most locations along the F- and H-Area seeplines where 1989 data are available for comparison, concentrations of most constituents have declined, particularly aluminum and sodium. Chloride concentrations for all seepline and stream locations are less than $8.0 \mathrm{mg} / \mathrm{L}$, within the range of concentrations observed in the groundwater monitoring wells in the area.

A list of the analytes and their corresponding sampling locations where July 1992 concentrations were measured above the 1989 concentrations and above either the PDWS or MCL is given in Table 12 . Two analytes met these criteria: ${ }^{129} \mathrm{I}$ and ${ }^{90} \mathrm{Sr}$.

Analytes where July 1992 concentrations exceeded those measured in 1989 and either the PDWS or MCL at one or more sampling location included:

\begin{tabular}{cc} 
Area & Analytes \\
\hline $\mathrm{F}$ & ${ }^{129} \mathrm{I}$ \\
$\mathrm{H}$ & ${ }^{129} \mathrm{I}$ \\
FMB & ${ }^{90} \mathrm{Sr}$
\end{tabular}

Several seepline locations in both $\mathrm{F}$ and $\mathrm{H}$ Area continue to be influenced by ${ }^{129} \mathrm{~T}$ and ${ }^{90} \mathrm{Sr}$. Contributions of ${ }^{90} \mathrm{Sr}$, ${ }^{129} \mathrm{I},{ }^{3} \mathrm{H}$ and ${ }^{137} \mathrm{Cs}$ from the $\mathrm{F}$ - and H-Area seepage basin operations continue to be measurable in FMB. 
Table 10. Correlation Between 1989 and July 1992 Sampling Locations

\begin{tabular}{ll} 
July 1992 & \multicolumn{1}{c}{1989} \\
\hline FMC001F & New Location \\
FMC001H & $89 H W 7$ \\
FMC002H & $89 H W 2$ \\
& \\
FSP012 & 89FW5 \\
FSP032 & 89FW6 \\
FSP047 & 89FW7 \\
FSP204 & 89FW3 \\
FSP290 & New Location \\
& \\
HSP008 & New Location \\
HSP029 & New Location \\
HSP043 & 89HW4 \\
HSP060 & New Location \\
HSP090 & New Location
\end{tabular}

Table 11. Analytes and Corresponding Sampling Locations Where 1992 Concentrations Exceeded 1989 Concentrations

\begin{tabular}{|c|c|c|c|c|c|c|c|c|c|}
\hline Analyte & Lab & $\operatorname{Mod}^{*}$ & 7/92 Result & Acc* & Standard & Mod* & 89-Result & Units & $\mathbf{m}$ \\
\hline Alkalinity & $\overline{G E}$ & $\mathrm{v}$ & 13.2 & & & & 8 & $\mathrm{mg} / \mathrm{L}$ & FMCOOLH \\
\hline Aluminum & GE & & 224 & & & & 130 & $\mu g / L$ & FSP047 \\
\hline Aluminum & GE & & 4440 & & & & 80 & $\mu g / L$ & HSP043 \\
\hline Cesium-137 & GP & & 102 & 7.6 & 200 & & 62 & $\mathrm{pCi} / \mathrm{L}$ & FMCOO1H \\
\hline Cesium-137 & GP & & 10.3 & 4.2 & 200 & & 4.4 & $\mathrm{pCi} / \mathrm{L}$ & $\mathrm{FMCOO2H}$ \\
\hline Chloride & $\mathrm{GE}$ & & 7.5 & & & & 5.5 & $\mathrm{mg} / \mathrm{L}$ & FMCO01H \\
\hline Chloride & $\mathrm{GE}$ & & 3.2 & & & & 1.9 & $\mathrm{mg} / \mathrm{L}$ & FSP012 \\
\hline Chioride & $G E$ & & 2.43 & & & & 2 & $\mathrm{mg} / \mathrm{L}$ & FSP032 \\
\hline Cbloride & $\mathrm{GE}$ & & 6.52 & & & & 3.8 & $\mathrm{mg} / \mathrm{L}$ & FSP047 \\
\hline Chloride & $\mathrm{GE}$ & & 3.86 & & & & 2.4 & $\mathrm{mg} / \mathrm{L}$ & FSP204 \\
\hline Chloride & $\mathrm{GE}$ & & 3.94 & & & & 1.2 & $\mathrm{mgll}$ & HSP043 \\
\hline Iodine-129 & $\mathrm{TE}$ & & 41.4 & 5.7 & 1 & $\mathbf{U}$ & 24 & $\mathrm{pCi} / \mathrm{L}$ & FSP204 \\
\hline Iodine-129 & $\mathrm{TE}$ & & 52.2 & 3.1 & 1 & $\mathrm{U}$ & 39 & $\mathrm{pCi} / \mathrm{L}$ & HSP043 \\
\hline Lead & $\mathrm{GE}$ & & 8.68 & & 15 & $\mathbf{U}$ & 3 & $\mu g / L$ & HSP043 \\
\hline Mercury & GE & & 0.22 & & 2 & $\mathrm{U}$ & 0.2 & $\mu \mathrm{g} / \mathrm{L}$ & FMCOO1H \\
\hline Mercury & GE & & 0.24 & & 2 & $\mathbf{U}$ & 0.2 & $\mu \mathrm{g} / \mathrm{L}$ & FSP012 \\
\hline Mercury & GE & & 0.47 & & 2 & $\mathbf{U}$ & 0.2 & $\mu \mathrm{g} / \mathrm{L}$ & FSP047 \\
\hline Mercury & $\mathrm{GE}$ & & 0.38 & & 2 & $\mathbf{U}$ & 0.2 & $\mu g / L$ & FSP204 \\
\hline Mercury & $G E$ & & 0.94 & & 2 & $\mathrm{U}$ & 0.2 & $\mu g / L$ & HSP043 \\
\hline Radium-226 & GP & & 1.66 & 0.31 & 15.7 & & . $\quad 1.2$ & $\mathrm{pCi} / \mathrm{L}$ & $\mathrm{FMC} 001 \mathrm{H}$ \\
\hline Sodium & $\mathrm{GE}$ & & 11900 & & & & 10200 & $\mu g / L$ & FMCOO1H \\
\hline Sodium & $G E$ & & 15400 & & & & 11700 & $\mu \mathrm{g} / \mathrm{L}$ & $\mathrm{FMCOO2H}$ \\
\hline Sodium & $\mathrm{GE}$ & & 41900 & & & & 63.3 & $\mu \mathrm{g} / \mathrm{L}$ & HSP043 \\
\hline
\end{tabular}


(Table 11. Continued)

\begin{tabular}{|c|c|c|c|c|c|c|c|c|c|}
\hline Analyte & Lab & $\operatorname{Mod}^{*}$ & 7/92 Result & $A c^{*}$ & Standard & Mod* & 89-Result & Units & $\mathbf{W}$ \\
\hline Strontium-90 & GP & & 12.4 & 2.7 & 8 & & 5.5 & $\mathrm{pCi} / \mathrm{L}$ & FMC001H \\
\hline Strontium-90 & GP & & 16.7 & 1.9 & 8 & & 6.8 & $\mathrm{pCi} / \mathrm{L}$ & $\mathrm{FMCOO2H}$ \\
\hline Zinc & GE & & 13.65 & & 5000 & $\mathbf{U}$ & 9 & $\mu g / L$ & $\mathrm{FMCOO2H}$ \\
\hline Zinc & GE & & 199 & & & $\mathbf{U}$ & 9 & $\mu g / L$ & HSP043 \\
\hline
\end{tabular}

*Analytical Modifier (See Table 14)

**Accuracy

Table 12. Analytes and Corresponding Sampling Locations Where 1992 Concentrations Exceeded 1989 Concentrations and Either the PDWS or MCL

\begin{tabular}{|c|c|c|c|c|c|c|c|c|c|}
\hline Analyte & Lab & Mod* $^{*}$ & $7 / 92$ Result & $A c c^{* *}$ & Standard & Mod* & 89-Result & Units & $\mathbf{m}$ \\
\hline Strontium-90 & GP & & 12.4 & 2.7 & 8 & & 5.5 & $\mathrm{pCi} / \mathrm{L}$ & $\mathrm{FMCOOIH}$ \\
\hline Strontium-90 & GP & & 16.7 & 1.9 & 8 & & 6.8 & $\mathrm{pCi} / \mathrm{L}$ & $\mathrm{FMC} 002 \mathrm{H}$ \\
\hline Iodine-129 & TE & & 41.4 & 5.7 & 1 & $\mathrm{U}$ & 24 & $\mathrm{pCi} / \mathrm{L}$ & FSP204 \\
\hline Iodine-129 & $\mathrm{TE}$ & & 52.2 & 3.1 & 1 & $\mathbf{U}$ & 39 & $\mathrm{pCi} / \mathrm{L}$ & HSPO43 \\
\hline
\end{tabular}

*Analytical Modifier (See Table 14)

**Accuracy 


\section{Technetium-99 Results}

${ }^{99}$ Tc was reported by Environmental Physics at concentrations greater than the PDWS at several locations. The reported concentrations were also elevated considerably above 1989 concentrations at the same locations. Reported concentrations ranged from 300 (detection limit) to 12,450 $\mathrm{pCi} / \mathrm{L}$. These results were suspect for several reasons.

- Reported concentrations were higher than any measured at the seepline in the past.

- Concentrations were higher than would be expected based on the total ${ }^{99} \mathrm{Tc}$ inventory for both $\mathrm{F}$ and $\mathrm{H}$ basins during their operating history.

- The lab performing split sample analyses rejected their ${ }^{99} \mathrm{Tc}$ results due to a matrix interference.

- Gross radiological indicators (gross alpha and gross beta) were not at concentrations sufficient to suggest that large quantities of ${ }^{99} \mathrm{Tc}$ were present in the samples.

A comparison of the analytical methods used by the two labs revealed that both used an acid extraction liquid scintillation procedure, which should have produced similar results. Both labs were contacted and asked to explain their ${ }^{99} \mathrm{Tc}$ methods and results. Environmental Physics reported that no interferences of any kind were noted in their analytical logs (including any mention of solids). Based on spike recoveries from the samples, they felt confident of their results. Clemson Technical Center reported a matrix interference (resulting from a large amount of solids) which they reported would greatly interfere with ${ }^{99} \mathrm{Tc}$ analyses and was expected to yield falsely elevated results. As expected, elevated results were obtained. Clemson Technical Center rejected the results because the noted matrix interference was expected to yield elevated results and the gross radiological indicators did not support that ${ }^{99} \mathrm{Tc}$ of the quantity suggested by the scintillation counts was present in the samples. Gross alpha and gross beta results reported by Environmental Physics did not indicate that ${ }^{99} \mathrm{Tc}$ of the quantity reported could be present in the samples.

Confirmation samples were collected in March 1993 and analyzed onsite by ETS using an ICP/MS method (Beals 1992) that eliminated the effect of matrix interferences resulting from suspended solids. The ICP/MS methodology also eliminated the possibility of erroneously counting other radionuclides with energies of similar magnitudes as ${ }^{99}$ Tc (i.e. ${ }^{3} \mathrm{H}$ ). This may account for the overestimation. The count window used by Environmental Physics for ${ }^{99} \mathrm{Tc}$ analyses ranged from 0 to $760 \mathrm{Kev}$. This count range includes both ${ }^{99} \mathrm{Tc}$ and ${ }^{3} \mathrm{H}$, which are both low-energy beta emitters. Examination of the results reveals that locations at which Environmental Physics reported elevated ${ }^{99} \mathrm{Tc}$ also reported elevated ${ }^{3} \mathrm{H}$. This suggests that, even though an acid extraction procedure was used in which the aqueous phase was to be separated and removed from the sample, a portion of the aqueous phase may have remained in the extract used for analysis. The aqueous portion of the extract would contain ${ }^{3} \mathrm{H}$, which would be counted as ${ }^{99} \mathrm{Tc}$, resulting in overestimation of ${ }^{99} \mathrm{Tc}$ concentration.

Results of the confirmation analyses showed that actual ${ }^{99} \mathrm{Tc}$ concentrations ranged from 19 to $108 \mathrm{pCi} / \mathrm{L}$. These results confirm that the acid extraction liquid scintillation methodologies used for ${ }^{99} \mathrm{Tc}$ analysis have overestimated the actual ${ }^{99} \mathrm{Tc}$ concentrations present in the samples. For water samples containing large amounts of suspended solids and/or ${ }^{3} \mathrm{H}$, this should be taken into consideration. Table 13 shows the results as reported by all three laboratories. For the purpose of this report, all ${ }^{99} \mathrm{Tc}$ results reported by Environmental Physics and Clemson Technical Center were considered inaccurate and excluded from all analyses.

Table 13. Comparison of ${ }^{99} \mathrm{Tc}$ Results Between Laboratories

\begin{tabular}{|c|c|c|c|c|c|c|c|c|c|c|}
\hline & \multicolumn{3}{|c|}{ Environmental Physics } & \multicolumn{3}{|c|}{ Clemson Technical Center } & \multicolumn{4}{|c|}{ Environmental Technology Section } \\
\hline Location & ${ }^{99} \mathrm{Tc}$ & Mod* & Method & ${ }^{99} \mathrm{Tc}$ & Mod & Method & ${ }^{99} \mathrm{Tc}$ & Mod & Method & Units \\
\hline FSP032 & 1650 & & HASL300 & & & & 19 & & Beals, 1992 & $\mathrm{pCi} / \mathrm{L}$ \\
\hline FSP204 & 2755 & & HASL300 & & & & 37 & & Beals, 1992 & $\mathrm{pCi} / \mathrm{L}$ \\
\hline HSP008 & 12450 & & HASL300 & 7300 & $\mathbf{R} 4^{* *}$ & MMEC038 & 108 & & Beals, 1992 & $\mathrm{pCi} / \mathrm{L}$ \\
\hline HSP029 & 1910 & & HASL300 & & & & 52 & & Beals, 1992 & $\mathrm{pCi} / \mathrm{L}$ \\
\hline HSPO43 & 6080 & & HASL300 & 7240 & R4 & MMEC038 & 60 & & Beals, 1992 & $\mathrm{pCi} / \mathrm{L}$ \\
\hline HSP060 & 8640 & & HASL 300 & & & & 31 & & Beals, 1992 & $\mathrm{pCi} / \mathrm{L}$ \\
\hline
\end{tabular}

\footnotetext{
*Analytical Modifier

**Analytical results were rejected due to a matrix interference.
} 


\section{Summary}

Results from the July 1992 sampling event of the semiannual sampling program along FMB and its seeplines suggest that the seeplines in both $\mathrm{F}$ and $\mathrm{H}$ Areas and FMB continue to be influenced by contaminants migrating from the F- and H-Area seepage basins.

Comparisons of F-Area seepline locations to background locations suggested that alkalinity, barium, calcium, and manganese were significantly impacting the seepline. Comparisons of $\mathrm{H}$-Area seepline locations to background suggested that aluminum, calcium, sodium, ${ }^{226} \mathrm{Ra}$, and ${ }^{3} \mathrm{H}$ were impacting the seepline. However, the July 1992 concentrations of most of these analytes (aluminum, sodium, etc.) had decreased substantially, compared to 1989 concentrations for the same sampling locations.

Comparisons of July 1992 concentrations to established standards revealed that several analytes were elevated above either the PDWS or MCL at one or more sampling location (seepline and stream). No metals concentrations were detected above the PDWS or MCL at any sampling location. Those analytes elevated above the PDWS or $\mathrm{MCL}$ at one or more locations for both the F- and H-Area seeplines and FMB included nonvolatile beta, ${ }^{3} \mathrm{H},{ }^{129} \mathrm{I}$ ${ }^{228} \mathrm{Ra}$, and ${ }^{90} \mathrm{Sr}$. Gross alpha in $\mathrm{H}$ Area and nitrate in both $F$ and $H$ Area were also above either the PDWS or MCL at one or more sampling locations.
Based on results from the July 1992 sampling event, the following analytes appear to be impacting the seeplines and stream:

\begin{tabular}{cl} 
Area & \multicolumn{1}{c}{ Analytes } \\
\hline F & $\begin{array}{l}\text { alkalinity, aluminum, barium, calcium, iron, } \\
\text { manganese, nitrate, nonvolatile beta, }{ }^{3} \mathrm{H},{ }^{129} \mathrm{I},\end{array}$ \\
& ${ }^{228} \mathrm{Ra}$, and ${ }^{90} \mathrm{Sr}$
\end{tabular}

While July 1992 results suggest that contaminant levels have declined somewhat since 1989, the concentrations of some radionuclides have remained unchanged. Further analysis based on future data from the semi-annual sampling program will allow for a more complete assessment of the temporal changes in the contaminant levels at FMB and its seeplines.

\section{Acknowledgment}

The authors of this report would like to thank R. Cary Tuckfield of the Scientific Computations Section-Applied Statistics Group for his assistance with the statistical analysis of the data presented in this report. 


\section{References}

Beals, D.M. 1992. Determination of technetiun-99 in aqueous samples by isotope dilution inductively coupled plasma - mass spectrometry. WSRC-MS-92-141, Westinghouse Savannah River Company, Savannah River Technology Center, Aiken, SC.

Clemson Technical Center. 1992. CWMI-CTC Radiochemistry Analytical Methods. CTCO009 - Alpha Spectrometer Analysis of Radioisotopes, 2/23/92. Clemson Technical Center, Inc., Clemson Research Park, 100 Technology Drive, Anderson, SC.

Conover, W.J. 1980. Practical Nonparametric Statistics. Second Edition. John Wiley and Sons, New York, NY.

Dixon, K.L. and V.A. Rogers. 1992a. Results of the first quarter tritium survey of the F-and H-Area seeplines: May 1992. WSRC-TR-92-304, Westinghouse Savannah River Company, Savannah River Technology Center, Aiken, SC.

Dixon, KL. and V.A. Rogers. 1992b. Results of the second quarter tritium survey of the F-and H-Area seeplines: September 1992. WSRC-TR-93-129, Westinghouse Savannah River Company, Savannah River Technology Center, Aiken, SC.

Environmental Monitoring Section. 1992. The Savannah River Site's Groundwater Monitoring Program, Second Quarter Report. ESH-EMS-920036, Westinghouse Savannah River Company, Savannah River Technology Center, Aiken, SC.

Fenimore, J.W. and J.H. Horton. 1972. Rating history and environmental effects of seepage basins in chemical separations areas of the Savannah River Plant. DPST72-548, E.I. du Pont de Nemours and Company, Savannah River Laboratory, Aiken, SC.

Haselow, J.S., M. Harris, B.B. Looney, N.V. Halverson, and J.B. Gladden. 1990. Analysis of soil and water at the Fourmile Branch seepline near the F- and H-Area of SRS. WSRC-RP-90-0591, Westinghouse Savannah River Company, Savannah River Laboratory, Aiken, $\mathrm{SC}$.

Killian, T.H., N.L. Kolb, P. Corbo, and I.W. Marine. 1985a. F-Area seepage basins. DPST-85-704, E.I. du Pont de Nemours and Company, Savannah River Laboratory, Aiken, SC.

Killian, T.H., NL. Kolb, P. Corbo, and I.W. Marine. 1985b. H-Area seepage basins. DPST-85-706, E.I. du Pont de Nemours and Company, Savannah River Laboratory, Aiken, SC.

Levene, H. 1960. Robust tests for the equality of variances. In I. Olkin (ed), Contributions to probability and statistics. Stanford University Press.
Looney, B.B., J.E. Cantrell, and J.R. Cook. 1988. Sampling and analysis of surface water in the vicinity of the F- and H-Area seepage basins. DPST-88-229, E.I. du Pont de Nemours and Company, Savannah River Laboratory, Aiken, SC.

Martin Marietta Energy Systems. 1992. Determination of Technetium-99 in Water TSD-533-330 (MMEC-038). Technical Services Division Procedures Manual, Martin Marietta Energy Systems, Portsmouth Gaseous Diffusion Plant, Pikedon, $\mathrm{OH}$.

Metcalf and Eddy. 1992. Fourmile Branch semi-annual sampling report: July 1992 sampling event. WSRCTR-92-559, Westinghouse Savannah River Company, Savannah River Technology Center, Aiken, SC.

Miller, R.G., Jr. 1981. Simultaneous Statistical Inference. Second Edition. Springer-Verlag, New York, NY.

Nixon, P., J. Osweiler, B. Thomas, L. St. Clair, D. Nix, R. Andersen, C. Spalding, E. Jennrich, and R. Shuman. 1991. RCRA/CERCLA integration document for the H-Area seepage basins groundwater unit. WSRC-RP91-1019, Westinghouse Savannah River Company, Aiken, SC.

Steel, R.G.D. and J.H. Torrie. 1980. Principles and Procedures of Statistics, A Biometric Approach. Second Edition. McGraw-Hill Book Company, New York, NY.

U.S. Department of Energy. 1992. Environmental Measurements Laboratory of the U.S. DOE, 376 Hudson St., New York, NY.

U.S. Environmental Protection Agency (EPA). 1977. National Interim Primary Drinking Water Regulations. EPA-570/9-76-003, Washington, D.C.

U.S. Environmental Protection Agency (EPA). 1980. Prescribed Procedures for Measurement of Radioactivity in Drinking Water. EPA-600/4-80-32. Cincinnati, $\mathrm{OH}$.

U.S. Environmental Protection Agency (EPA). 1983. Methrods for Chemical Analysis of Water and Wastes. PB84-128677. Cincinnati, OH.

U.S. Environmental Protection Agency (EPA). 1986a. Test Methods for Evaluating Solid Waste, Vol. 1A, 1B, and 1C, Third edition. SW846. Washington, D.C.

U.S. Environmental Protection Agency (EPA). 1986a. Water Pollution Control; National Primary Drinking Water Regulations; Radionuclides; Proposed. Federal Register, September 30, 1986, pp. 34835-34862, Washington, D.C.

U.S. Environmental Protection Agency (EPA). 1990. National Primary and Secondary Drinking Water Regulations; Synthetic Organic Chemicals and Inorganic Chemicals; Proposed. Federal Register, July 25, 1990, pp. 30369-30448, Washington, D.C. 
U.S. Environmental Protection Agency (EPA). 1991a. National Primary Drinking Water Regulations. Code of Federal Regulations, Title 40, Part 141, pp. 578715, Washington, D.C.

U.S. Environmental Protection Agency (EPA). 1991b. National Secondary Drinking Water Regulations. Code of Federal Regulations, Title 40, Part 143, pp. 758-762, Washington, D.C.

U.S. Environmental Protection Agency (EPA). 1991c. National Primary Drinking Water Regulations; Radionuclides; Proposed; Federal Register, July 18, 1991. pp. 33052-33127, Washington, D.C.
U.S. Environmental Protection Agency (EPA). 1993. National Primary Drinking Water Regulations - Safe Drinking Water Act Maximum Contaminant Levels (MCL), Rev 3, Code of Federal Regulations, Title 40, Part 141, pp. 589-729, Washington, D.C.

Welch, BL. (1951). On the comparison of several mean values: an altemative approach. Biometrika 38:330336.

WSRC-3Q5 (Ch. 12) (DPSOP 254). Hydrogeologic data collection. Westinghouse Savannah River Company, Aiken, SC. 


\section{Analytical Results}

The analytical results from the July 1992 sampling event of the semi-annual sampling program for Fourmile Branch and its seeplines is presented in this section. The analytical data for each sampling location is presented in tabular form with the background samples presented first followed by the stream samples, F-Area seepline samples (FSP), HArea seepline samples (HSP), trip blank samples (QA 2S and QA 4S), and the remaining QA samples (QA 1-4).

For each sampling location, the results of all field measurements are presented including sampling date, depth to water, $\mathrm{pH}$, and specific conductance. This information is followed by all laboratory analyses for that sampling location. For each analyte in the laboratory analyses table, the following information is presented: the lab that performed the analyses, any analytical modifiers, the analytical results, the accuracy of the result (for detected radiological parameters only), any appropriate standard for comparison, and the units in which the results are presented. Table 14 lists the analytical modifiers used to qualify any analytical results.

The following is a list of abbreviations used in the tables:

\begin{tabular}{|c|c|}
\hline Lab & Laboratory performing analysis \\
\hline Mod & Analytical modifer \\
\hline Acc & $\begin{array}{l}\text { Accuracy of the result (detected radiological } \\
\text { parameters only) }\end{array}$ \\
\hline GE & General Engineering \\
\hline GP & Environmental Physics \\
\hline WA & Weston Analytics \\
\hline $\mathrm{CN}$ & Clemson Technical Center \\
\hline $\mathrm{TE}$ & Teledyne Isotopes \\
\hline TM & TMA/Eberline \\
\hline
\end{tabular}

Table 14. Analytical Modifiers

Result

Quallifer

Definition

(Blank) Data not qualified. Number should be interpreted exactly as reported

J Estimated because quantitation in the sample or in associated quality control samples did not meet specifications

L Off-scale high. The actual value is not known, but is known to be greater than the value shown

$M \quad$ Presence of the analyte is verified, but not quantified

Q Sample held beyond normal holding time. If the holding time is exceeded by less than 30 days, the sample is coded QJ; if the holding time is exceeded by 30 days or more, the sample is coded $Q R$

$R$ Rejected because performance requirements in the sample analysis or associated quality control analyses were not met

U Undetected; if present, below the criteria of detection

V Indicates the analyte was detected in the associated method blank

1 The associated result may be an underestimation of the true value due to analytical bias

2 The associated result may be an overestimation of the true value due to analytical bias

3 The associated result may be of poor precision (high variability) due to analytical bias

4 Matrix interference

5 The sample result is four or more times greater than the standard concentration

6 Re-analyzed out of holding time because of problems with the original analysis 
Table 15. BG001 Laboratory Analyses

Field Measurements:

Sample Date: 07/29/92

pH: 4.82

Specific Conductance: $21 \mu \mathrm{S} / \mathrm{cm}$

\begin{tabular}{|c|c|c|c|c|c|c|}
\hline \multirow[b]{2}{*}{ Analyte } & \multicolumn{4}{|c|}{7192} & \multirow[b]{2}{*}{ Standard } & \multirow[b]{2}{*}{ Units } \\
\hline & Lab & Mod & Result & Acc & & \\
\hline Alkalinity & GE & & 1.43 & & & $\mathrm{mg} / \mathrm{L}$ \\
\hline Aluminum & GE & & 175 & & & $\mu \mathrm{g} / \mathrm{L}$ \\
\hline Americium-241 & GP & $\mathrm{U}$ & 1 & & 6.34 & $\mathrm{pCi} / \mathrm{L}$ \\
\hline Ammonia nitrogen & $\mathrm{GE}$ & U & 0.1 & & & $\mathrm{mg} / \mathrm{L}$ \\
\hline Antimony & GE & U & 2 & & 5 & $\mu \mathrm{g} / \mathrm{L}$ \\
\hline Antimony-125 & GP & U & 20 & & 300 & $\mathrm{pCi} / \mathrm{L}$ \\
\hline Arsenic & GE & $\mathrm{U}$ & 2 & & 50 & $\mu \mathrm{g} / \mathrm{L}$ \\
\hline Barium & GE & & 12.2 & & 2000 & $\mu g / L$ \\
\hline Beryllium & GE & $\mathbf{U}$ & 3 & & 1 & $\mu g / L$ \\
\hline Cadmium & GE & $\mathbf{U}$ & 2 & & 5 & $\mu g / L$ \\
\hline Calcium & GE & & 262 & & & $\mu g / L$ \\
\hline Carbon tetrachloride & GE & $\mathbf{U}$ & 1 & & 5 & $\mu g / L$ \\
\hline Cerium-144 & GP & $\mathbf{U}$ & 60 & & 261 & $\mathrm{pCi} / \mathrm{L}$ \\
\hline Cesium-134 & GP & $\mathbf{U}$ & 10 & & 81.3 & $\mathrm{pCi} / \mathrm{L}$ \\
\hline Cesium-137 & GP & $\mathbf{U}$ & 10 & & 200 & $\mathrm{pCi} / \mathrm{L}$ \\
\hline Chloride & GE & & 1.85 & & & $\mathrm{mg} / \mathrm{L}$ \\
\hline Chloroform & GE & $\mathbf{U}$ & 1 & & 100 & $\mu g / L$ \\
\hline Chromium & GE & $\mathbf{U}$ & 4 & & 100 & $\mu \mathrm{g} / \mathrm{L}$ \\
\hline Cobalt-57 & GP & $\mathbf{U}$ & 10 & & 1000 & $\mathrm{pCi} / \mathrm{L}$ \\
\hline Cobalt- 60 & GP & $\mathbf{U}$ & 10 & & 100 & $\mathrm{pCi} / \mathrm{L}$ \\
\hline Copper & GE & $\mathbf{U}$ & 4 & & 1300 & $\mu g / L$ \\
\hline Curium-242 & GP & $\mathbf{U}$ & 1 & & 0.133 & $\mathrm{pCi} / \mathrm{L}$ \\
\hline Curium-243,244 & GP & $\mathbf{U}$ & 1 & & 8.3 & $\mathrm{pCi} / \mathrm{L}$ \\
\hline Europium-152 & GP & $\mathbf{U}$ & 40 & & & $\mathrm{pCi} / \mathrm{L}$ \\
\hline Europium-154 & GP & U & 20 & & 200 & $\mathrm{pCi} / \mathrm{L}$ \\
\hline Europium-155 & GP & U & 30 & & 600 & $\mathrm{pCi} / \mathrm{L}$ \\
\hline Fluoride & GE & U & 0.1 & & 4 & $\mathrm{mg} / \mathrm{L}$ \\
\hline Gross alpha & $\mathrm{GE}$ & & 2.5 & 1.45 & 15 & pCi/L \\
\hline Hardness & GE & & 8.5 & & & $\mathrm{mg} / \mathrm{L}$ \\
\hline Iodine-129 & IE & $\mathrm{U}$ & 2 & & 1 & $\mathrm{pCi} / \mathrm{L}$ \\
\hline Iron & GE & $\mathrm{J} 2$ & 186 & & 300 & $\mu g / L$ \\
\hline Lead & GE & & 3.16 & & 15 & $\mu g / L$ \\
\hline Magnesium & $G E$ & & 349 & & & $\mu g / L$ \\
\hline Manganese & GE & & 18.4 & & 50 & $\mu g / L$ \\
\hline Manganese-54 & GP & $\mathbf{U}$ & 10 & & 300 & $\mathrm{pCi} / \mathrm{L}$ \\
\hline Mercury & GE & & 0.37 & & 2 & $\mu g / L$ \\
\hline Neptunium-237 & TE & $\mathrm{U}$ & 10 & & 7.06 & $\mathrm{pCi} / \mathrm{L}$ \\
\hline Nickel & GE & $\mathbf{U}$ & 4 & & 100 & $\mu g / L$ \\
\hline Nitrate as nitrogen & GE & & 0.26 & & 10 & $\mathrm{mg} / \mathrm{L}$ \\
\hline Nonvolatile beta & GE & & 2.1 & 1.6 & 50 & $\mathrm{pCi} / \mathrm{L}$ \\
\hline Plutonium-238 & GP & $\mathrm{U}$ & 1 & & 7.02 & $\mathrm{pCi} / \mathrm{L}$ \\
\hline Plutonium-239,240 & GP & $\mathrm{U}$ & 1 & & 62.1 & $\mathrm{pCi} / \mathrm{L}$ \\
\hline Potassium & GE & $\mathrm{U}$ & 500 & & & $\mu g / L$ \\
\hline Potassium -40 & GP & $\mathrm{U}$ & 110 & & 300 & $\mathrm{pCi} / \mathrm{L}$ \\
\hline Promethium-144 & GP & U & 10 & & & $\mathrm{pCi} / \mathrm{L}$ \\
\hline
\end{tabular}


(Table 15. Continued)

\begin{tabular}{|c|c|c|c|c|c|c|}
\hline \multirow[b]{2}{*}{ Analyte } & \multirow[b]{2}{*}{ Lab } & \multicolumn{3}{|c|}{$7 / 92$} & \multirow[b]{2}{*}{ Standard } & \multirow[b]{2}{*}{ Units } \\
\hline & & Mod & Result & Acc & & \\
\hline Promethium-146 & GP & $\mathrm{U}$ & 10 & & & $\mathrm{pCi} / \mathrm{L}$ \\
\hline Radium-226 & GP & & 1.26 & 0.2 & 15.7 & $\mathrm{pCi} / \mathrm{L}$ \\
\hline Radium-228 & GP & & 5.23 & 0.78 & 7.85 & $\mathrm{pCi} / \mathrm{L}$ \\
\hline Ruthenium-106 & GP & $\mathrm{U}$ & 90 & & 30 & $\mathrm{pCi} / \mathrm{L}$ \\
\hline Selenium & GE & UJ1 & 2 & & 50 & $\mu \mathrm{g} / \mathrm{L}$ \\
\hline Silver & GE & $\mathrm{U}$ & 2 & & 50 & $\mu \mathrm{g} / \mathrm{L}$ \\
\hline Sodium & GE & & 794 & & & $\mu g / L$ \\
\hline Sodium-22 & GP & $\mathbf{U}$ & 10 & & 466 & $\mathrm{pCi} / \mathrm{L}$ \\
\hline Strontium-90 & $\mathrm{GP}$ & $\mathrm{U}$ & 2 & & 8 & $\mathrm{pCi} / \Omega$ \\
\hline Technetium-99 & GP & U & 300 & & 900 & $\mathrm{pCi} / \mathrm{L}$ \\
\hline Tetrachloroethylene & GE & U & 1 & & 5 & $\mu g / L$ \\
\hline Thallium & $\mathrm{GE}$ & $\mathrm{U}$ & 2 & & 1 & $\mu g / L$ \\
\hline Thorium-228 & GP & $\mathrm{U}$ & 1 & & 125 & $\mathrm{pCi} / \mathrm{L}$ \\
\hline Thorium-230 & GP & $\mathrm{U}$ & 1 & & 79.2 & $\mathrm{pCi} / \mathrm{L}$ \\
\hline Thorium-232 & GP & $\mathbf{U}$ & 1.14 & & 88 & $\mathrm{pCi} / \mathrm{L}$ \\
\hline Tin & GE & U & 2 & & & $\mu g / L$ \\
\hline Total organic carbon & $\mathrm{GE}$ & & 7 & & & $\mathrm{mg} / \mathrm{L}$ \\
\hline Total organic halogens & $\mathrm{GE}$ & & 9.2 & & & $\mu g / L$ \\
\hline Total phenols & GE & $\mathrm{U}$ & 5 & & & $\mu \mathrm{g} / \mathrm{L}$ \\
\hline Trichloroethylene & $G E$ & $\mathrm{U}$ & 1 & & 5 & $\mu g / L$ \\
\hline Tritium & GE & & 8.15 & 0.5 & 20 & $\mathrm{pCi} / \mathrm{ml}$ \\
\hline Uranium-234 & GP & $\mathrm{U}$ & 1 & & 13.9 & $\mathrm{pCi} / \mathrm{L}$ \\
\hline Uranium-235 & GP & $\mathrm{U}$ & 1 & & 14.5 & $\mathrm{pCi} / \mathrm{L}$ \\
\hline Uranium-238 & GP & $\mathrm{U}$ & 1 & & 14.6 & $\mathrm{pCi} / \mathrm{L}$ \\
\hline Vanadium & GE & $\mathrm{U}$ & 8 & & & $\mu \mathrm{g} / \mathrm{L}$ \\
\hline Yttrium-88 & GP & $\mathrm{U}$ & 60 & & & $\mathrm{pCi} / \mathrm{L}$ \\
\hline Zinc & GE & & 95.2 & & 5000 & $\mu g / L$ \\
\hline Zinc-65 & GP & $U$ & 20 & & 300 & $\mathrm{pCi} / \mathrm{L}$ \\
\hline
\end{tabular}


Table 16. BG002 Laboratory Analyses

Field Measurements:

Sample Date: 07/29/92

pH: 5.00

Specific Conductance: $38 \mu \mathrm{S} / \mathrm{cm}$

\begin{tabular}{|c|c|c|c|c|c|c|}
\hline Anslyte & Lab & Mod & $\begin{array}{c}7 / 92 \\
\text { Result }\end{array}$ & $A \propto c$ & Standard & Units \\
\hline 1,1,1-Trichloroethane & $\overline{G E}$ & $\mathrm{U}$ & 1 & & 200 & $\mu g / L$ \\
\hline Alkalinity & GE & & 1.43 & & & $\mathrm{mg} / \mathrm{L}$ \\
\hline Aluminum & GE & & 256 & & & $\mu \mathrm{g} / \mathrm{L}$ \\
\hline Americium-241 & GP & $\mathbf{U}$ & 1 & & 6.34 & $\mathrm{pCi} / \mathrm{L}$ \\
\hline Ammonia nitrogen & GE & $\mathbf{U}$ & 0.1 & & & $\mathrm{mg} / \mathrm{L}$ \\
\hline Antimony & GE & $\mathbf{U}$ & 2 & & 5 & $\mu g / L$ \\
\hline Antimony-125 & GP & $\mathbf{U}$ & 20 & & 300 & $\mathrm{pCi} / \mathrm{L}$ \\
\hline Arsenic & GE & $\mathbf{U}$ & 2 & & 50 & $\mu \mathrm{g} / \mathrm{L}$ \\
\hline Barium & GE & & 20.8 & & 2000 & $\mu g / L$ \\
\hline Beryllium & GE & $\mathbf{U}$ & 3 & & 1 & $\mu \mathrm{g} / \mathrm{L}$ \\
\hline Cadmium & GE & $\mathbf{U}$ & 2 & & 5 & $\mu g / L$ \\
\hline Calcium & GE & & 487 & & & $\mu g / L$ \\
\hline Carbon tetrachioride & GE & $\mathrm{U}$ & 1 & & 5 & $\mu g / L$ \\
\hline Cerium-144 & GP & $\mathbf{U}$ & 60 & & 261 & $\mathrm{pCi} / \mathrm{L}$ \\
\hline Cesium-134 & GP & $\mathrm{U}$ & 10 & & 81.3 & $\mathrm{pCi} / \mathrm{L}$ \\
\hline Cesium-137 & GP & $\mathrm{U}$ & 10 & & 200 & $\mathrm{pCi} / \mathrm{L}$ \\
\hline Chloride & GE & & 2.98 & & & $\mathrm{mg} / \mathrm{L}$ \\
\hline Chloroform & GE & $\mathbf{U}$ & 1 & & 100 & $\mu \mathrm{g} / \mathrm{L}$ \\
\hline Chromium & GE & U & 4 & & 100 & $\mu g / L$ \\
\hline Cobalt-57 & GP & $\mathbf{U}$ & 10 & & 1000 & $\mathrm{pCi} / L$ \\
\hline Cobalt -60 & GP & $\mathbf{U}$ & 10 & & 100 & $\mathrm{pCi} / \mathrm{L}$ \\
\hline Copper & GE & U & 4 & & 1300 & $\mu g / L$ \\
\hline Curium-242 & GP & $\mathrm{U}$ & 1 & & 0.133 & $\mathrm{PCi} / \mathrm{L}$ \\
\hline Curium-243,244 & GP & $\mathbf{U}$ & 1 & & 8.3 & $\mathrm{pCi} / \mathrm{L}$ \\
\hline Europium-152 & GP & $\mathbf{U}$ & 40 & & & $\mathrm{pCi} / \mathrm{L}$ \\
\hline Europium-154 & GP & $\mathbf{U}$ & 20 & & 200 & $\mathrm{pCi} / \mathrm{L}$ \\
\hline Europium-155 & GP & $\mathrm{U}$ & 30 & & 600 & $\mathrm{pCi} / \mathrm{L}$ \\
\hline Fluoride & $G E$ & $\mathbf{U}$ & 0.1 & & 4 & $\mathrm{mg} / \mathrm{L}$ \\
\hline Gross alpha & GE & & 4.9 & 1.9 & 15 & $\mathrm{pCi} / \mathrm{L}$ \\
\hline Hardness & GE & & 22 & & & $\mathrm{mg} / \mathrm{L}$ \\
\hline Iodine-129 & $\mathrm{TE}$ & $\mathbf{U}$ & 2 & & 1 & $\mathrm{pCi} / \mathrm{L}$ \\
\hline Iron & $\mathrm{GE}$ & $\mathrm{J} 2$ & 1980 & & 300 & $\mu g / L$ \\
\hline Lead & GE & $\mathrm{U}$ & 3 & & 15 & $\mu g / L$ \\
\hline Magnesium & $G E$ & & 502 & & & $\mu g / \mathrm{L}$ \\
\hline Manganese & GE & & 41.95 & & 50 & $\mu \mathrm{g} / \mathrm{L}$ \\
\hline Manganese-54 & GP & $\mathrm{U}$ & 10 & & 300 & $\mathrm{pCi} / \mathrm{L}$ \\
\hline Mercury & GE & & 0.47 & & 2 & $\mu \mathrm{g} / \mathrm{L}$ \\
\hline Neptunium-237 & TE & $\mathrm{U}$ & 10 & & 7.06 & $\mathrm{pCi} / \mathrm{L}$ \\
\hline Nickel & GE & $\mathrm{U}$ & 4 & & 100 & $\mu g / L$ \\
\hline Nitrate as nitrogen & GE & & 0.23 & & 10 & $\mathrm{mg} / \mathrm{L}$ \\
\hline Nonvolatile beta & GE & & 4.6 & 1.6 & 50 & $\mathrm{pCi} / \mathrm{L}$ \\
\hline Plutonium-238 & GP & $\mathrm{U}$ & 1 & & 7.02 & $\mathrm{pCi} / \mathrm{L}$ \\
\hline Plutonium-239,240 & GP & $\mathbf{U}$ & 1 & & 62.1 & $\mathrm{pCi} /$ \\
\hline Potassium & GE & & 671 & & & $\mu \mathrm{g} / \mathrm{L}$ \\
\hline Potassium-40 & GP & U & 110 & & 300 . & $\mathrm{pCi} / \mathrm{L}$ \\
\hline Promethium-144 & GP & $\mathbf{U}$ & 10 & & & $\mathrm{pCi} / \mathrm{L}$ \\
\hline
\end{tabular}


(Table 16. Continued)

\begin{tabular}{|c|c|c|c|c|c|c|}
\hline Analyte & Lab & Mod & $\begin{array}{c}7 / 92 \\
\text { Result }\end{array}$ & $A \propto c$ & Standard & Units \\
\hline Promethium-146 & GP & $\bar{U}$ & 10 & & & $\mathrm{pCi} / \mathrm{L}$ \\
\hline Radium-226 & GP & $\mathrm{U}$ & 1 & & 15.7 & $\mathrm{pCi} / \mathrm{L}$ \\
\hline Radium-228 & GP & & 4.73 & 1.2 & 7.85 & $\mathrm{pCi} / \mathrm{L}$ \\
\hline Ruthenium-106 & GP & $\mathrm{U}$ & 90 & & 30 & $\mathrm{pCi} / \mathrm{L}$ \\
\hline Selenium & GE & UJ1 & 2 & & 50 & $\mu g / L$ \\
\hline Silver & GE & U & 2 & & 50 & $\mu g / L$ \\
\hline Sodium & GE & & 1260 & & & $\mu \mathrm{g} / \mathrm{L}$ \\
\hline Sodium-22 & GP & $\mathrm{U}$ & 10 & & 466 & $\mathrm{pCi} / \mathrm{L}$ \\
\hline Strontium-90 & GP & & 3.86 & 1.8 & 8 & $\mathrm{pCi} / \mathrm{L}$ \\
\hline Technetium-99 & GP & U & 300 & & 900 & $\mathrm{pCi} / \mathrm{L}$ \\
\hline Tetrachloroethylene & $\mathrm{GE}$ & $\mathbf{U}$ & 1 & & 5 & $\mu g / L$ \\
\hline Thallium & GE & U & 2 & & 1 & $\mu g / L$ \\
\hline Thorium-228 & GP & $\mathrm{U}$ & 1 & & 125 & $\mathrm{pC} / \mathrm{L}$ \\
\hline Thorium-230 & GP & U & 1 & & 79.2 & $\mathrm{pCi} / \mathrm{L}$ \\
\hline Thorium-232 & GP & $\mathrm{U}$ & 1 & & 88 & $\mathrm{pC} / / L$ \\
\hline Tin & GE & & 2.81 & & & $\mu g / L$ \\
\hline Total organic carbon & $\mathrm{GE}$ & & 21 & & & $\mathrm{mg} / \mathrm{L}$ \\
\hline Total organic balogens & GE & & 25.1 & & & $\mu g / L$ \\
\hline Total phenols & GE & $\mathrm{U}$ & 5 & & & $\mu g / L$ \\
\hline Trichloroethylene & $\mathrm{GE}$ & U & 1 & & 5 & $\mu \mathrm{g} / \mathrm{L}$ \\
\hline Tritium & $\mathrm{GE}$ & & 4.86 & 0.4 & 20 & $\mathrm{PCi} / \mathrm{ml}$ \\
\hline Uranium-234 & GP & $\mathbf{U}$ & 1 & & 13.9 & $\mathrm{pCi} / \mathrm{L}$ \\
\hline Uranium-235 & GP & $\mathrm{U}$ & 1 & & 14.5 & $\mathrm{pCi} / \mathrm{L}$ \\
\hline Uranium-238 & GP & U & 1 & & 14.6 & $\mathrm{PCi} / \mathrm{L}$ \\
\hline Vanadium & $G E$ & $\mathrm{U}$ & 8 & & & $\mu \mathrm{g} / \mathrm{L}$ \\
\hline Yttrium-88 & GP & $\mathrm{U}$ & 60 & & & $\mathrm{pCi} / \mathrm{L}$ \\
\hline Zine & $\mathrm{GE}$ & & 143 & & 5000 & $\mu g / L$ \\
\hline Zinc-65 & GP & $\mathrm{U}$ & 20 & & 300 & pCi凡 \\
\hline
\end{tabular}


Table 17. BG003 Laboratory Analyses

Field Measurements:

Sample Date: 07/22/92

pH: 5.80

Specific Conductance: $20 \mu \mathrm{S} / \mathrm{cm}$

\begin{tabular}{|c|c|c|c|c|c|c|}
\hline Analyte & Lab & Mod & $\begin{array}{c}7 / 92 \\
\text { Result }\end{array}$ & Acc & Standard & Units \\
\hline 1,1,1-Trichloroethane & $\overline{G E}$ & $\bar{U}$ & 1 & & 200 & $\mu g / L$ \\
\hline Alkalinity & GE & v & 5 & & & $\mathrm{mg} / \mathrm{L}$ \\
\hline Aluminum & $\mathrm{GE}$ & & 73.9 & & & $\mu g / L$ \\
\hline Americium-241 & GP & $U$ & 1 & & 6.34 & $\mathrm{pCi} / \mathrm{L}$ \\
\hline Ammonia nitrogen & GE & $\mathbf{U}$ & 0.1 & & & $\mathrm{mg} / \mathrm{L}$ \\
\hline Antimony & GE & $\mathrm{U}$ & 2 & & 5 & $\mu g / L$ \\
\hline Antimony-125 & GP & $\mathbf{U}$ & 20 & & 300 & $\mathrm{pCi} / \mathrm{L}$ \\
\hline Arsenic & $\mathrm{GE}$ & $\mathrm{U}$ & 2 & & 50 & $\mu g / L$ \\
\hline Barium & GE & & 24.5 & & 2000 & $\mu g / L$ \\
\hline Beryllium & GE & $\mathrm{U}$ & 3 & & 1 & $\mu g / L$ \\
\hline Cadmium & GE & $\mathrm{U}$ & 2 & & 5 & $\mu g / L$ \\
\hline Calcium & GE & & 1260 & & & $\mu g / L$ \\
\hline Carbon tetrachloride & GE & $\mathrm{U}$ & 1 & & 5 & $\mu g / L$ \\
\hline Cerium-144 & GP & $\mathrm{U}$ & 60 & & 261 & $\mathrm{pCi} / \mathrm{L}$ \\
\hline Cesium-134 & GP & $\mathrm{U}$ & 10 & & 81.3 & $\mathrm{pCi} / \mathrm{L}$ \\
\hline Cesium-137 & GP & $\mathrm{U}$ & 10 & & 200 & $\mathrm{pCi} / \mathrm{L}$ \\
\hline Chloride & GE & & 2.68 & & & $\mathrm{mg} / \mathrm{L}$ \\
\hline Chloroform & GE & U & 1 & & 100 & $\mu \mathrm{g} / \mathrm{L}$ \\
\hline Chromium & $\mathrm{GE}$ & U & 4 & & 100 & $\mu g / L$ \\
\hline Cobalt-57 & GP & $\mathbf{U}$ & 10 & & 1000 & $\mathrm{pCi} / \mathrm{L}$ \\
\hline Cobalt -60 & GP & $\mathrm{U}$ & 10 & & 100 & $\mathrm{pCi} / \mathrm{L}$ \\
\hline Copper & $\mathrm{GE}$ & $\mathbf{U}$ & 4 & & 1300 & $\mu g / L$ \\
\hline Curium-242 & GP & $\mathbf{U}$ & 1 & & 0.133 & $\mathrm{pCi} / \mathrm{L}$ \\
\hline Curium-243,244 & GP & $\mathbf{U}$ & 1 & & 8.3 & $\mathrm{pCi} / \mathrm{L}$ \\
\hline Europium-152 & GP & $U$ & 40 & & & $\mathrm{pCi} / \mathrm{L}$ \\
\hline Europium-154 & GP & $\mathrm{U}$ & 20 & & 200 & $\mathrm{pCi} / \mathrm{L}$ \\
\hline Europium-155 & GP & $\mathrm{U}$ & 30 & & 600 & $\mathrm{pCi} / \mathrm{L}$ \\
\hline Fluoride & $\mathrm{GE}$ & $\mathrm{U}$ & 0.1 & & 4 & $\mathrm{mg} / \mathrm{L}$ \\
\hline Gross alpha & $\mathrm{GE}$ & $\mathrm{U}$ & 2 & & 15 & $\mathrm{pCi} / \mathrm{L}$ \\
\hline Hardness & $\mathrm{GE}$ & & 5.4 & & & $\mathrm{mg} / \mathrm{L}$ \\
\hline Iodine-129 & $\mathbf{T E}$ & $\mathrm{U}$ & 2 & & 1 & $\mathrm{pCi} / \mathrm{L}$ \\
\hline Iron & $\mathrm{GE}$ & & 843 & & 300 & $\mu g / L$ \\
\hline Lead & $\mathrm{GE}$ & & 4.48 & & 15 & $\mu g / L$ \\
\hline Magnesium & GE & & 468 & & & $\mu g / L$ \\
\hline Manganese & $G E$ & & 223 & & 50 & $\mu g / L$ \\
\hline Manganese-54 & GP & U & 10 & & 300 & $\mathrm{pCi} / \mathrm{L}$ \\
\hline Mercury & $G E$ & U & 0.2 & & 2 & $\mu g / L$ \\
\hline Neptunium-237 & $\mathrm{TE}$ & U & 10 & & 7.06 & $\mathrm{pCi} / \mathrm{L}$ \\
\hline Nickel & $\mathrm{GE}$ & $\mathrm{U}$ & 4 & & 100 & $\mu g / L$ \\
\hline Nitrate as nitrogen & GE & $\mathbf{U}$ & 0.05 & & 10 & $\mathrm{mg} / \mathrm{L}$ \\
\hline Nonvolatile beta & GE & UV & 2 & & 50 & $\mathrm{pCi} / \mathrm{L}$ \\
\hline Plutonium-238 & GP & $\mathbf{U}$ & 1 & & 7.02 & $\mathrm{pCi} / \mathrm{L}$ \\
\hline Plutonium-239,240 & $G P$ & U & 1 & & 62.1 & $\mathrm{pCi} / \mathrm{L}$ \\
\hline Potassium & GE & $\mathrm{U}$ & 500 & & & $\mu g / L$ \\
\hline Potassium -40 & GP & U & 110 & & 300 & $\mathrm{pCi} / \mathrm{L}$ \\
\hline Promethium-144 & GP & U & 10 & & & $\mathrm{pCi} / \mathrm{L}$ \\
\hline
\end{tabular}


(Table 17. Continued)

\begin{tabular}{|c|c|c|c|c|c|c|}
\hline Analyte & $\mathbf{L a b}$ & Mod & $\begin{array}{c}7 / 92 \\
\text { Result } \\
\end{array}$ & $A \propto$ & Standard & Units \\
\hline Promethium-146 & GP & $\mathrm{U}$ & 10 & & & $\mathrm{pCi} / \mathrm{L}$ \\
\hline Radium-226 & GP & U & 1 & & 15.7 & $\mathrm{pC} / / L$ \\
\hline Radium-228 & GP & & 2.2 & 0.88 & 7.85 & $\mathrm{pC} / \mathrm{i} / \mathrm{L}$ \\
\hline Ruthenium-106 & GP & $\mathbf{U}$ & 90 & & 30 & $\mathrm{pCi} / \mathrm{L}$ \\
\hline Selenium & GE & UJ1 & 2 & & 50 & $\mu \mathrm{g} / \mathrm{L}$ \\
\hline Silver & $\mathrm{GE}$ & $\mathrm{U}$ & 2 & & 50 & $\mu g / L$ \\
\hline Sodium & GE & & 2120 & & & $\mu \mathrm{g} / \mathrm{L}$ \\
\hline Sodium-22 & GP & U & 10 & & 466 & $\mathrm{pCi} / \mathrm{L}$ \\
\hline Strontium-90 & GP & U & 2 & & 8 & $\mathrm{pCi} / \mathrm{L}$ \\
\hline Technetium-99 & GP & $\mathbf{U}$ & 300 & & 900 & $\mathrm{pCi} / \mathrm{L}$ \\
\hline Tetrachloroethylene & GE & $\mathrm{U}$ & 1 & & 5 & $\mu g / L$ \\
\hline Thallium & $\mathrm{GE}$ & $\mathbf{U}$ & 2 & & 1 & $\mu g / L$ \\
\hline Thorium-228 & GP & $\mathrm{U}$ & 1 & & 125 & $\mathrm{pCi} / \mathrm{L}$ \\
\hline Thorium-230 & GP & $\mathrm{U}$ & 1 & & 79.2 & $\mathrm{pCi} / 2$ \\
\hline Thorium-232 & GP & $\mathrm{U}$ & 1 & & 88 & $\mathrm{pCi} / \mathrm{L}$ \\
\hline Tin & GE & $\mathbf{U}$ & 2 & & & $\mu g / L$ \\
\hline Total organic carbon & GE & & 9 & & & $\mathrm{mg} / \mathrm{L}$ \\
\hline Total organic halogens & GE & & 18 & & & $\mu g / L$ \\
\hline Total phenols & GE & U & 5.05 & & & $\mu g / L$ \\
\hline Trichloroethylene & GE & $\mathrm{U}$ & 1 & & 5 & $\mu g / L$ \\
\hline Tritium & GE & & 1.97 & 0.4 & 20 & $\mathrm{pCi} / \mathrm{ml}$ \\
\hline Uranium-234 & GP & U & 1 & & 13.9 & $\mathrm{pCi} / \mathrm{L}$ \\
\hline Uranium-235 & GP & $\mathrm{U}$ & 1 & & 14.5 & $\mathrm{pCi} / \mathrm{L}$ \\
\hline Uranium-238 & GP & $\mathbf{U}$ & 1 & & 14.6 & $\mathrm{pCi} / \mathrm{L}$ \\
\hline Vanadium & $\mathrm{GE}$ & U & 8 & & & $\mu g / L$ \\
\hline Yttrium-88 & GP & $\mathrm{U}$ & 60 & & & $\mathrm{pCi} / \mathrm{L}$ \\
\hline Zinc & GE & & 14 & & 5000 & $\mu g / L$ \\
\hline Zinc-65 & GP & $\mathrm{U}$ & 20 & & 300 & $\mathrm{pCi} / \mathrm{L}$ \\
\hline
\end{tabular}


Table 18. FMC001F Laboratory Analyses

Field Measurements:

Sample Date: 07/22/92

pH: 6.75

Specific Conductance: $70 \mathrm{uS} / \mathrm{cm}$

\begin{tabular}{|c|c|c|c|c|c|c|}
\hline \multirow{2}{*}{ Analyte } & \multirow[b]{2}{*}{ Lab } & \multicolumn{3}{|c|}{$7 / 92$} & \multirow[b]{2}{*}{ Standard } & \multirow[b]{2}{*}{ Units } \\
\hline & & Mod & Result & $\mathbf{A} \boldsymbol{c}$ & & \\
\hline 1,1,1-Trichloroethane & GE & $\mathbf{U}$ & 1 & & 200 & $\mu g / L$ \\
\hline Alkalinity & GE & $\mathrm{V}$ & 14.6 & & & $\mathrm{mg} / \mathrm{L}$ \\
\hline Aluminum & GE & & 107 & & & $\mu g / L$ \\
\hline Americium-241 & GP & $\mathbf{U}$ & 1 & & 6.34 & $\mathrm{pCi} / \mathrm{L}$ \\
\hline Ammonia nitrogen & GE & $\mathrm{U}$ & 0.1 & & & $\mathrm{mg} / \mathrm{L}$ \\
\hline Antimony & GE & U & 2 & & 5 & $\mu \mathrm{g} / \mathrm{L}$ \\
\hline Antimony-125 & GP & $\mathrm{U}$ & 20 & & 300 & $\mathrm{pCi} / \mathrm{L}$ \\
\hline Arsenic & GE & $\mathrm{U}$ & 2 & & 50 & $\mu g / L$ \\
\hline Barium & GE & & 21.9 & & 2000 & $\mu g / L$ \\
\hline Beryllium & $\mathrm{GE}$ & U & 3 & & 1 & $\mu \mathrm{g} / \mathrm{L}$ \\
\hline Cadmium & $\mathrm{GE}$ & $\mathbf{U}$ & 2 & & 5 & $\mu \mathrm{g} / \mathrm{L}$ \\
\hline Calcium & GE & & 3300 & & & $\mu g / L$ \\
\hline Carbon tetrachloride & $\mathrm{GE}$ & $\mathbf{U}$ & 1 & & 5 & $\mu g / L$ \\
\hline Cerium-144 & GP & $\mathbf{U}$ & 60 & & 261 & $\mathrm{pCi} / \mathrm{L}$ \\
\hline Cesium-134 & GP & $\mathbf{U}$ & 10 & & 81.3 & $\mathrm{pCi} / \mathrm{L}$ \\
\hline Cesium-137 & GP & & 16.1 & 3.8 & 200 & $\mathrm{pCi} / \mathrm{L}$ \\
\hline Chloride & GE & & 3.36 & & & $\mathrm{mg} / \mathrm{L}$ \\
\hline Chloroform & GE & $\mathbf{U}$ & 1 & & 100 & $\mu g / L$ \\
\hline Chromium & $\mathrm{GE}$ & $\mathbf{U}$ & 4 & & 100 & $\mu g / L$ \\
\hline Cobalt-57 & GP & $\mathbf{U}$ & 10 & & 1000 & $\mathrm{pCi} / \mathrm{L}$ \\
\hline Cobalt- 60 & GP & $\mathbf{U}$ & 10 & & 100 & $\mathrm{pCi} / \mathrm{L}$ \\
\hline Copper & GE & U & 4 & & 1300 & $\mu g / L$ \\
\hline Currium-242 & GP & $\mathrm{U}$ & 1 & & 0.133 & $\mathrm{pCi} / \mathrm{L}$ \\
\hline Curium-243,244 & GP & $\mathbf{U}$ & 1 & & 8.3 & $\mathrm{pCi} / \mathrm{L}$ \\
\hline Europium-152 & GP & $\mathbf{U}$ & 40 & & & $\mathrm{pCi} / \mathrm{L}$ \\
\hline Europium-154 & GP & U & 20 & & 200 & $\mathrm{pCi} / \mathrm{L}$ \\
\hline Europium-155 & GP & $\mathrm{U}$ & 30 & & 600 & $\mathrm{pCi} / \mathrm{L}$ \\
\hline Fluoride & $\mathrm{GE}$ & U & 0.1 & & 4 & $\mathrm{mg} / \mathrm{L}$ \\
\hline Gross alpha & GE & $\mathbf{U}$ & 2 & & 15 & $\mathrm{pCi} / \mathrm{L}$ \\
\hline Hardness & $\mathrm{GE}$ & & 20 & & & $\mathrm{mg} / \mathrm{L}$ \\
\hline Iodine-129 & $\mathrm{TE}$ & & 2.8 & 1.3 & 1 & $\mathrm{pCi} / \mathrm{L}$ \\
\hline Iron & $\mathrm{GE}$ & & 392 & & 300 & $\mu g / L$ \\
\hline Lead & $\mathrm{GE}$ & $\mathbf{U}$ & 3 & & 15 & $\mu g / L$ \\
\hline Magnesium & GE & & 646 & & & $\mu g / L$ \\
\hline Manganese & GE & & 47.2 & & 50 & $\mu g / L$ \\
\hline Manganese-54 & GP & $\mathrm{U}$ & 10 & & 300 & $\mathrm{pCi} / \mathrm{L}$ \\
\hline Mercury & GE & $\mathbf{U}$ & 0.2 & & 2 & $\mu \mathrm{g} / \mathrm{L}$ \\
\hline Neptunium-237 & TE & $\mathrm{U}$ & 10 & & 7.06 & $\mathrm{pCi} / \mathrm{L}$ \\
\hline Nickel & GE & $\mathbf{U}$ & 4 & & 100 & $\mu g / L$ \\
\hline Nitrate as nitrogen & GE & & 2.38 & & 10 & $\mathrm{mg} / \mathrm{L}$ \\
\hline Nonvolatile beta & GE & $\mathbf{V}$ & 47.5 & 3.9 & 50 & $\mathrm{pCi} / \mathrm{L}$ \\
\hline Plutonium-238 & GP & $\mathrm{U}$ & 1 & & 7.02 & $\mathrm{pCi} / \mathrm{L}$ \\
\hline Plutonium-239,240 & GP & U & 1 & & 62.1 & $\mathrm{pCi} / \mathrm{L}$ \\
\hline Potassium & $\mathrm{GE}$ & & 505 & & & $\mu g / L$ \\
\hline Potassium-40 & GP & $\mathbf{U}$ & 110 & & 300 & $\mathrm{pCi} / \mathrm{L}$ \\
\hline Promethium-144 & GP & $\mathbf{U}$ & 10 & & & $\mathrm{pCi} / \mathrm{L}$ \\
\hline
\end{tabular}


(Table 18. Continued)

\begin{tabular}{|c|c|c|c|c|c|c|}
\hline Analyte & Lab & Mod & $\begin{array}{c}\text { 7/92 } \\
\text { Result }\end{array}$ & Ace & Standard & Units \\
\hline Promethium-146 & GP & $\mathrm{U}$ & 10 & & & $\mathrm{pCi} / \mathrm{L}$ \\
\hline Radium-226 & GP & & 1.16 & 0.25 & 15.7 & $\mathrm{pCi} / \mathrm{L}$ \\
\hline Radium-228 & GP & & 16.5 & 1.4 & 7.85 & $\mathrm{pCi} / \mathrm{L}$ \\
\hline Ruthenium-106 & GP & $\mathbf{U}$ & 90 & & 30 & $\mathrm{pCi} / \mathrm{L}$ \\
\hline Selenium & GE & US1 & 2 & & 50 & $\mu g / L$ \\
\hline Silver & GE & U & 2 & & 50 & $\mu g / \mathrm{L}$ \\
\hline Sodium & GE & & 9720 & & & $\mu g / L$ \\
\hline Sodium-22 & GP & $\mathbf{U}$ & 10 & & 466 & $\mathrm{pCi} / \mathrm{L}$ \\
\hline Strontium-90 & GP & & 27.9 & 3.7 & 8 & $\mathrm{pCi} / \mathrm{L}$ \\
\hline Technetium-99 & GP & 1270 & 56 & & 900 & $\mathrm{pCi} / \mathrm{L}$ \\
\hline Tetrachloroethylene & GE & $\mathbf{U}$ & 1 & & 5 & $\mu g / L$ \\
\hline Thallium & GE & $\mathrm{U}$ & 2 & & 1 & $\mu g / L$ \\
\hline Thorium-228 & GP & $\mathbf{U}$ & 1 & & 125 & $\mathrm{pCi} / \mathrm{L}$ \\
\hline Thorium-230 & GP & $\mathbf{U}$ & 1 & & 79.2 & $\mathrm{pCi} / \mathrm{L}$ \\
\hline Thorium-232 & GP & $\mathrm{U}$ & 1 & & 88 & $\mathrm{pCi} / \mathrm{L}$ \\
\hline Tin & GE & $\mathrm{U}$ & 2 & & & $\mu g / L$ \\
\hline Total organic carbon & GE & & 5.22 & & & $\mathrm{mg} / \mathrm{L}$ \\
\hline Total organic halogens & GE & & 91.7 & & & $\mu g / L$ \\
\hline Total phenols & GE & $U$ & 5 & & & $\mu g / L$ \\
\hline Trichloroethylene & GE & $U$ & 1 & & 5 & $\mu g / L$ \\
\hline Tritium & GE & & 640 & 3.8 & 20 & $\mathrm{PCi} / \mathrm{ml}$ \\
\hline Uranium-234 & GP & U & 1 & & 13.9 & $\mathrm{pCi} / \mathrm{L}$ \\
\hline Uranium-235 & GP & U & 1 & & 14.5 & $\mathrm{pCi} / \mathrm{L}$ \\
\hline Uranium-238 & GP & U & 1 & & 14.6 & $\mathrm{pCi} / \mathrm{L}$ \\
\hline Vanadium & GE & U & 8 & & & $\mu g / L$ \\
\hline Yttrium-88 & GP & $U$ & 60 & & & $\mathrm{pCi} / \mathrm{L}$ \\
\hline Zinc & GE & & 31.8 & & 5000 & $\mu \mathrm{g} / \mathrm{L}$ \\
\hline Zinc-65 & GP & U & 20 & & 300 & $\mathrm{pCi} / \mathrm{L}$ \\
\hline
\end{tabular}


Table 19. FMC001H Laboratory Analyses

Field Measurements:

Sample Date: 07/22/92

pH: 7.19

Specific Conductance: $86 \mu \mathrm{S} / \mathrm{cm}$

\begin{tabular}{|c|c|c|c|c|c|c|c|c|}
\hline \multirow{2}{*}{ Analyte } & \multicolumn{5}{|c|}{$7 / 92$} & \multicolumn{3}{|c|}{1989} \\
\hline & Lab & Mod & Result & $A \propto$ & Standard & Mod & Result & Units \\
\hline 1,1,1-Trichloroethane & GE & $\mathbf{U}$ & 1 & & 200 & & & $\mu g / L$ \\
\hline Alkalinity & $\mathrm{GE}$ & $\mathbf{v}$ & 13.2 & & & & 8 & $\mathrm{mg} / \mathrm{L}$ \\
\hline Aluminum & $\mathrm{GE}$ & & 102 & & & & 470 & $\mu g / L$ \\
\hline Americium-241 & GP & $\mathbf{U}$ & 1 & & 6.34 & & & $\mathrm{pCi} / \mathrm{L}$ \\
\hline Ammonia nitrogen & $\mathrm{GE}$ & & 0.3 & & & & & $\mathrm{mg} / \mathrm{L}$ \\
\hline Antimony & $\mathrm{GE}$ & $\mathbf{U}$ & 2 & & 5 & & & $\mu \mathrm{g} / \mathrm{L}$ \\
\hline Antimony-125 & GP & $\mathbf{U}$ & 20 & & 300 & & & $\mathrm{pCi} / \mathrm{L}$ \\
\hline Arsenic & $\mathrm{GE}$ & $\mathbf{U}$ & 2 & & 50 & $\mathrm{U}$ & 3 & $\mu \mathrm{g} / \mathrm{L}$ \\
\hline Barium & $\mathrm{GE}$ & & 13.3 & & 2000 & & & $\mu g / L$ \\
\hline Beryllium & GE & $\mathbf{U}$ & 3 & & 1 & & & $\mu \mathrm{g} / \mathrm{L}$ \\
\hline Cadmium & GE & $\mathrm{U}$ & 2 & & 5 & $\mathrm{U}$ & 6 & $\mu g / L$ \\
\hline Calcium & $\mathrm{GE}$ & & 3210 & & & & & $\mu \mathrm{g} / \mathrm{L}$ \\
\hline Carbon tetrachloride & GE & $\mathbf{U}$ & 1 & & 5 & & & $\mu \mathrm{g} / \mathrm{L}$ \\
\hline Cerium-144 & GP & $\mathbf{U}$ & 60 & & 261 & & & $\mathrm{pCi} / \mathrm{L}$ \\
\hline Cesium-134 & GP & $\mathrm{U}$ & 10 & & 81.3 & $\mathrm{U}$ & 5.3 & $\mathrm{pCi} / \mathrm{L}$ \\
\hline Cesium-137 & GP & & 102 & 7.6 & 200 & & 62 & $\mathrm{pCi} / \mathrm{L}$ \\
\hline Chloride & $\mathrm{GE}$ & & 7.5 & & & & 5.5 & $\mathrm{mg} / \mathrm{L}$ \\
\hline Chloroform & GE & & 1.2 & & 100 & & & $\mu g / L$ \\
\hline Chromium & $\mathrm{GE}$ & $\mathbf{U}$ & 4 & & 100 & & 2.1 & $\mu g / L$ \\
\hline Cobalt-57 & GP & $\mathrm{U}$ & 10 & & 1000 & & & $\mathrm{pCi} / \mathrm{L}$ \\
\hline Cobalt-60 & GP & $\mathbf{U}$ & 10 & & 100 & $\mathrm{U}$ & 1.1 & $\mathrm{pCi} / \mathrm{L}$ \\
\hline Copper & $\mathrm{GE}$ & & 5.72 & & 1300 & & & $\mu g / L$ \\
\hline Curium-242 & GP & $\mathbf{U}$ & 1 & & 0.133 & & & $\mathrm{pCi} / \mathrm{L}$ \\
\hline Curium-243,244 & GP & $\mathbf{U}$ & 1 & & 8.3 & & & $\mathrm{pCi} / \mathrm{L}$ \\
\hline Europium-152 & GP & $\mathbf{U}$ & 40 & & & & & $\mathrm{pCi} / \mathrm{L}$ \\
\hline Europium-154 & GP & $\mathrm{U}$ & 20 & & 200 & & & $\mathrm{pCi} / \mathrm{L}$ \\
\hline Europium-155 & GP & $\mathbf{U}$ & 30 & & 600 & & & $\mathrm{pCi} / \mathrm{L}$ \\
\hline Fluoride & $\mathrm{GE}$ & $\mathbf{U}$ & 0.1 & & 4 & & & $\mathrm{mg} / \mathrm{L}$ \\
\hline Gross alpha & $\mathrm{GE}$ & $\mathbf{U}$ & 2 & & 15 & $\mathrm{U}$ & 3 & $\mathrm{pCi} / \mathrm{L}$ \\
\hline Hardness & $\mathrm{GE}$ & & 11.3 & & & & 196 & $\mathrm{mg} / \mathrm{L}$ \\
\hline Iodine-129 & $\mathrm{TE}$ & U & 2 & & 1 & $\mathrm{U}$ & 47 & $\mathrm{pCi} / \mathrm{L}$ \\
\hline Iron & $\mathrm{GE}$ & & 349 & & 300 & & & $\mu g / L$ \\
\hline Lead & GE & & 3.87 & & 15 & & 4.9 & $\mu g / L$ \\
\hline Magnesium & $\mathrm{GE}$ & & 477 & & & & & $\mu \mathrm{g} / \mathrm{L}$ \\
\hline Manganese & $\mathrm{GE}$ & & 65.3 & & 50 & & & $\mu \mathrm{g} / \mathrm{L}$ \\
\hline Manganese-54 & GP & $\mathbf{U}$ & 10 & & 300 & & & $\mathrm{pCi} / \mathrm{L}$ \\
\hline Mercury & $\mathrm{GE}$ & & 0.22 & & 2 & $\mathrm{U}$ & 0.2 & $\mu \mathrm{g} / \mathrm{L}$ \\
\hline Neptunium-237 & $\mathrm{TE}$ & $\mathbf{U}$ & 10 & & 7.06 & $\mathbf{U}$ & 1 & $\mathrm{pCi} / \mathrm{L}$ \\
\hline Nickel & $\mathrm{GE}$ & $\mathbf{U}$ & 4 & & 100 & $\mathrm{U}$ & 34 & $\mu g / L$ \\
\hline Nitrate as nitrogen & $\mathrm{GE}$ & & 0.99 & & 10 & & 5.7 & $\mathrm{mg} / \mathrm{L}$ \\
\hline Nonvolatile beta & $\mathrm{GE}$ & v & 65.5 & 4.5 & 50 & & 190 & $\mathrm{pCi} / \mathrm{L}$ \\
\hline Plutonium-238 & GP & $\mathbf{U}$ & 1 & & 7.02 & $\mathbf{U}$ & 1 & $\mathrm{pCi} / \mathrm{L}$ \\
\hline Plutonium-239,240 & GP & $\mathbf{U}$ & 1 & & 62.1 & $\mathrm{U}$ & 1 & $\mathrm{pCi} / \mathrm{L}$ \\
\hline Potassium & $\mathrm{GE}$ & & 1900 & & & & & $\mu \mathrm{g} / \mathrm{L}$ \\
\hline Potassium-40 & GP & $\mathbf{U}$ & 110 & & 300 & & & $\mathrm{pCi} / \mathrm{L}$ \\
\hline Promethium-144 & GP & $\mathbf{U}$ & 10 & & & & & $\mathrm{pCi} / \mathrm{L}$ \\
\hline
\end{tabular}


(Table 19. Continued)

\begin{tabular}{|c|c|c|c|c|c|c|c|c|}
\hline Analyte & Lab & Mod & $\begin{array}{c}\text { 7/92 } \\
\text { Result }\end{array}$ & Acc & Standard & Mod & $\begin{array}{c}1989 \\
\text { Result }\end{array}$ & Units \\
\hline Promethium-146 & GP & $\mathrm{U}$ & 10 & & & & & $\mathrm{pCi} / \mathrm{L}$ \\
\hline Radium-226 & GP & & 1.66 & 0.31 & 15.7 & & 1.2 & $\mathrm{pCi} / \mathrm{L}$ \\
\hline Radium-228 & GP & & 6.11 & 2.8 & 7.85 & & & $\mathrm{pCi} / \mathrm{L}$ \\
\hline Ruthenium-106 & GP & $\mathbf{U}$ & 90 & & 30 & & & $\mathrm{pCi} / \mathrm{L}$ \\
\hline Selenium & GE & UJ1 & 2 & & 50 & $\mathbf{U}$ & 2 & $\mu g / L$ \\
\hline Silver & GE & $\mathbf{U}$ & 2 & & 50 & $\mathbf{U}$ & 4 & $\mu g / L$ \\
\hline Sodium & GE & & 11900 & & & & 10200 & $\mu g / L$ \\
\hline Sodium-22 & GP & $\mathbf{U}$ & 10 & & 466 & & & $\mathrm{pCi} / \mathrm{L}$ \\
\hline Strontium-90 & GP & & 12.4 & 2.7 & 8 & & 5.5 & $\mathrm{pCi} / \mathrm{L}$ \\
\hline Technetium-99 & GP & $\mathbf{U}$ & 300 & & 900 & $\mathrm{U}$ & 7 & $\mathrm{pCi} / \mathrm{L}$ \\
\hline Tetrachloroethylene & GE & $\mathrm{U}$ & 1 & & 5 & & & $\mu g / L$ \\
\hline Thallium & GE & $\mathbf{U}$ & 2 & & 1 & & & $\mu g / L$ \\
\hline Thorium-228 & GP & $\mathbf{U}$ & 1 & & 125 & & & $\mathrm{pCi} / 2$ \\
\hline Thorium-230 & GP & $\mathbf{U}$ & 1 & & 79.2 & & & $\mathrm{pCi} / \mathrm{L}$ \\
\hline Thorium-232 & GP & $\mathbf{U}$ & 1 & & 88 & & & $\mathrm{pCi} / \mathrm{L}$ \\
\hline Tin & GE & $\mathbf{U}$ & 2 & & & & & $\mu g / L$ \\
\hline Total organic carbon & GE & & 2.8 & & & & & $\mathrm{mg} / \mathrm{L}$ \\
\hline Total organic halogens & GE & & 41.5 & & & & & $\mu g / L$ \\
\hline Total phenols & GE & $\mathrm{U}$ & 5 & & & & & $\mu \mathrm{g} / \mathrm{L}$ \\
\hline Trichloroethylene & GE & $\mathbf{U}$ & 1 & & 5 & & & $\mu g / L$ \\
\hline Tritium & GE & & 72.8 & 1.3 & 20 & & 86 & $\mathrm{pCi} / \mathrm{ml}$ \\
\hline Uranium-234 & GP & U & 1 & & 13.9 & & & $\mathrm{pCi} / \mathrm{L}$ \\
\hline Uranium-235 & GP & U & 1 & & 14.5 & & & $\mathrm{pCi} / \mathrm{L}$ \\
\hline Uranium-238 & GP & U & 1 & & 14.6 & U & 1 & $\mathrm{pCi} / \mathrm{L}$ \\
\hline Vanadium & GE & $\mathrm{U}$ & 8 & & & & & $\mu g / L$ \\
\hline Yttrium-88 & GP & U & 60 & & & & & $\mathrm{pCi} / \mathrm{L}$ \\
\hline Zinc & GE & & 24.9 & & 5000 & & 28 & $\mu \mathrm{g} / \mathrm{L}$ \\
\hline Zinc-65 & GP & U & 20 & & 300 & & & $\mathrm{pCi} / \mathrm{L}$ \\
\hline
\end{tabular}


Table 20. FMCO02H Laboratory Analyses

Field Measurements:

Sample Date: 07/22/92

pH: 6.67

Specific Conductance: $94 \mu \mathrm{S} / \mathrm{cm}$

\begin{tabular}{|c|c|c|c|c|c|c|c|c|}
\hline & & & $7 / 92$ & & & & 1989 & \\
\hline Analyte & Lab & Mod & Result & $A \infty$ & Standard & Mod & Result & Units \\
\hline 1,1,1-Trichloroethane & GE & $\overline{\mathbf{U}}$ & 1 & & 200 & & & $\mu \mathrm{g} / \mathrm{L}$ \\
\hline Alkalinity & $G E$ & $\mathbf{V}$ & 33.2 & & & & & $\mathrm{mgll}$ \\
\hline Aluminum & $\mathrm{GE}$ & & 42.2 & & & & 50 & $\mu g / L$ \\
\hline Americium-241 & GP & $\mathbf{U}$ & 1 & & 6.34 & & & $\mathrm{pCi} / \mathrm{L}$ \\
\hline Ammonia nitrogen & GE & $\mathrm{U}$ & 0.1 & & & & & $\mathrm{mg} / \mathrm{L}$ \\
\hline Antimony & $\mathrm{GE}$ & $\mathrm{U}$ & 2 & & 5 & & & $\mu \mathrm{g} / \mathrm{L}$ \\
\hline Antimony-125 & GP & $\mathrm{U}$ & 20 & & 300 & & & $\mathrm{pCi} / \mathrm{L}$ \\
\hline Arsenic & $\mathrm{GE}$ & $\mathbf{U}$ & 2 & & 50 & $\mathrm{U}$ & 3 & $\mu g /$ \\
\hline Barium & $\mathrm{GE}$ & & 26.15 & & 2000 & & & $\mu \mathrm{g} / \mathrm{L}$ \\
\hline Beryllium & $\mathrm{GE}$ & $\mathbf{U}$ & 3 & & 1 & & & $\mu g / L$ \\
\hline Cadmium & $\mathrm{GE}$ & U & 2 & & 5 & $\mathrm{U}$ & 6 & $\mu g / L$ \\
\hline Calcium & GE & & 4150 & & & & & $\mu \mathrm{g} / \mathrm{L}$ \\
\hline Carbon tetrachloride & $\mathrm{GE}$ & $\mathbf{U}$ & 1 & & 5 & & & $\mu \mathrm{g} / \mathrm{L}$ \\
\hline Cerium-144 & $G P$ & U & 60 & & 261 & & & $\mathrm{pCil}$ \\
\hline Cesium-134 & GP & $\mathrm{U}$ & 10 & & 81.3 & $\mathrm{U}$ & 9.1 & $\mathrm{pCi} / \mathrm{L}$ \\
\hline Cesium-137 & GP & & 10.3 & 4.2 & 200 & & 4.4 & $\mathrm{pCi} / \mathrm{L}$ \\
\hline Chloride & $\mathrm{GE}$ & & 2.93 & & & & 4.6 & $\mathrm{mg} / \mathrm{L}$ \\
\hline Chloroform & $\mathrm{GE}$ & $U$ & 1 & & 100 & & & $\mu g / L$ \\
\hline Chromium & $\mathrm{GE}$ & U & 4 & & 100 & $\mathbf{U}$ & 7 & $\mu g / L$ \\
\hline Cobalt-57 & GP & $\mathbf{U}$ & 10 & . & 1000 & & & $\mathrm{pCi} / \mathrm{L}$ \\
\hline Cobalt- 60 & GP & $\mathbf{U}$ & 10 & & 100 & $\mathbf{U}$ & 4.7 & $\mathrm{pCi} / \mathrm{L}$ \\
\hline Copper & $\mathrm{GE}$ & U & 4 & & 1300 & & & $\mu \mathrm{g} / \mathrm{L}$ \\
\hline Curium-242 & GP & $\mathbf{U}$ & 1 & & 0.133 & & & $\mathrm{pCi} / \mathrm{L}$ \\
\hline Curium-243,244 & GP & $\mathbf{U}$ & 1 & & 8.3 & & & $\mathrm{pCi} / \mathrm{L}$ \\
\hline Europium-152 & GP & $\mathbf{U}$ & 40 & & & & & $\mathrm{pCi} / \mathrm{L}$ \\
\hline Europium-154 & GP & U & 20 & & 200 & & & $\mathrm{pCi} / \mathrm{L}$ \\
\hline Europium-155 & GP & U & 30 & & 600 & & & $\mathrm{pCi} / \mathrm{L}$ \\
\hline Fluoride & GE & $\mathrm{U}$ & 0.1 & & 4 & & & $\mathrm{mg} / \mathrm{L}$ \\
\hline Gross alpha & GE & U & 2 & & 15 & & 4 & $\mathrm{pCi} / \mathrm{L}$ \\
\hline Hardness & GE & & 13.2 & & & & 139 & $\mathrm{mg} / \mathrm{L}$ \\
\hline Iodine-129 & TE & U & 2 & & 1 & U & 61 & $\mathrm{pCi} / \mathrm{L}$ \\
\hline Iron & GE & & 9195 & & 300 & & & $\mu g / L$ \\
\hline Lead & $\mathrm{GE}$ & U & 3 & & 15 & $\mathrm{U}$ & 3 & $\mu \mathrm{g} / \mathrm{L}$ \\
\hline Magnesium & GE & & 630 & & & & & $\mu \mathrm{g} / \mathrm{L}$ \\
\hline Manganese & $G E$ & & 704 & & 50 & & & $\mu g / L$ \\
\hline Manganese- 54 & GP & U & 10 & & 300 & & & $\mathrm{pCi} / L$ \\
\hline Mercury & GE & $\mathbf{U}$ & 0.2 & & 2 & $\mathbf{U}$ & 0.2 & $\mu g / L$ \\
\hline Neptunium-237 & $\mathrm{TE}$ & $\mathrm{U}$ & 10 & & 7.06 & U & 1 & $\mathrm{pCi} / \mathrm{L}$ \\
\hline Nickel & GE & $\mathrm{U}$ & 4 & & 100 & $\mathrm{U}$ & 34 & $\mu g / L$ \\
\hline Nitrate as nitrogen & GE & U & 0.05 & & 10 & & 1.4 & $\mathrm{mg} / \mathrm{L}$ \\
\hline Nonvolatile beta & $G E$ & $\mathrm{v}$ & 32.7 & 3.3 & 50 & & 39 & $\mathrm{pCi} / \mathrm{L}$ \\
\hline Plutonium-238 & GP & U & 1 & & 7.02 & $\mathbf{U}$ & 1 & $\mathrm{pCi} / \mathrm{L}$ \\
\hline Plutonium-239,240 & GP & $\mathbf{U}$ & 1 & & 62.1 & $\mathrm{U}$ & 1 & $\mathrm{pCi} / \mathrm{L}$ \\
\hline Potassium & $\mathrm{GE}$ & $\mathrm{U}$ & 500 & & & & & $\mu \mathrm{g} / \mathrm{L}$ \\
\hline Potassium -40 & GP & U & 110 & & 300 & & & $\mathrm{pCi} / \mathrm{L}$ \\
\hline Promethium-144 & GP & U & 10 & & & & & $\mathrm{pCi} / \mathrm{L}$ \\
\hline
\end{tabular}


(Table 20. Continued)

\begin{tabular}{|c|c|c|c|c|c|c|c|c|}
\hline \multirow[b]{2}{*}{ Analyte } & \multicolumn{5}{|c|}{$7 / 92$} & \multicolumn{3}{|c|}{1989} \\
\hline & Lab & Mod & Result & $A \infty$ & Standard & Mod & Result & Units \\
\hline Promethium-146 & GP & $\overline{\mathrm{U}}$ & 10 & & & & & $\mathrm{pCi} / 2$ \\
\hline Radium-226 & GP & $\mathbf{U}$ & 1 & & 15.7 & & 1.8 & $\mathrm{pCi} / \mathrm{L}$ \\
\hline Radium-228 & GP & & 11.4 & 1.2 & 7.85 & & & $\mathrm{pCi} / \mathrm{L}$ \\
\hline Ruthenium-106 & GP & $\mathbf{U}$ & 90 & & 30 & & & $\mathrm{pCi} / \mathrm{L}$ \\
\hline Selenium & GE & UJ1 & 2 & & 50 & $\mathbf{U}$ & 2 & $\mu g / L$ \\
\hline Silver & GE & $\mathbf{U}$ & 2 & & 50 & $\mathrm{U}$ & 4 & $\mu g / L$ \\
\hline Sodium & $G E$ & & 15400 , & & & & 11700 & $\mu g / L$ \\
\hline Sodium-22 & GP & $\mathrm{U}$ & 10 & & 466 & & & $\mathrm{pCi} / \mathrm{L}$ \\
\hline Strontium-90 & GP & & 16.7 & 1.9 & 8 & & 6.8 & $\mathrm{pCi} / \mathrm{L}$ \\
\hline Technetium-99 & $\mathrm{GP}$ & & 403 & 42 & 900 & & 50 & $\mathrm{pCi} / \mathrm{L}$ \\
\hline Tetrachloroethylene & $\mathrm{GE}$ & U & 1 & & 5 & & & $\mu g / L$ \\
\hline Thallium & $\mathrm{GE}$ & U & 2 & & 1 & & & $\mu g / L$ \\
\hline Thorium-228 & GP & $\mathbf{U}$ & 1 & & 125 & & & $\mathrm{pCi} / \mathrm{L}$ \\
\hline Thorium-230 & $G P$ & $U$ & 1 & & 79.2 & & & $\mathrm{pCi} / \mathrm{L}$ \\
\hline Thorium-232 & GP & $\mathrm{U}$ & 1 & & 88 & & & $\mathrm{pCi} / \mathrm{L}$ \\
\hline Tin & $\mathrm{GE}$ & U & 2.41 & & & & & $\mu g / L$ \\
\hline Total organic carbon & $\mathrm{GE}$ & & 6.42 & & & & & $\mathrm{mg} / \mathrm{L}$ \\
\hline Total organic halogens & GE & & 82.5 & & & & & $\mu g / L$ \\
\hline Total phenols & $\mathrm{GE}$ & $\mathrm{U}$ & 5 & & & & & $\mu g / L$ \\
\hline Trichloroethylene & $\mathrm{GE}$ & $\mathrm{U}$ & 1 & & 5 & & & $\mu g / L$ \\
\hline Tritium & GE & & 170 & 2 & 20 & & 1100 & $\mathrm{pCi} / \mathrm{ml}$ \\
\hline Uranium-234 & GP & U & 1 & & 13.9 & & & $\mathrm{pCi} / \mathrm{L}$ \\
\hline Uranium-235 & GP & U & 1 & & 14.5 & & & $\mathrm{pCi} / \mathrm{L}$ \\
\hline Uranium-238 & GP & U & 1 & & 14.6 & $\mathrm{U}$ & 1 & $\mathrm{pCi} / \mathrm{L}$ \\
\hline Vanadium & GE & $\mathrm{U}$ & 8 & & & & & $\mu \mathrm{g} / \mathrm{L}$ \\
\hline Yttrium-88 & GP & $\mathrm{U}$ & 60 & & & & & $\mathrm{pCi} / \mathrm{L}$ \\
\hline Zinc & GE & & 13.65 & & 5000 & $\mathrm{U}$ & 9 & $\mu g / L$ \\
\hline Zinc-65 & $G P$ & $U$ & 20 & & 300 & & & $\mathrm{pCi} / \mathrm{L}$ \\
\hline
\end{tabular}


Table 21. FSP012 Laboratory Analyses

Field Measurements:

Sample Date: 07/28/92

pH: 5.14

Specific Conductance: $106 \mu \mathrm{S} / \mathrm{cm}$

\begin{tabular}{|c|c|c|c|c|c|c|c|c|}
\hline \multirow{2}{*}{ Analyte } & \multicolumn{5}{|c|}{$7 / 92$} & \multicolumn{3}{|c|}{1989} \\
\hline & Lab & Mod & Result & $A \propto c$ & Standard & Mod & Result & Undts \\
\hline 1,1,1-Trichloroethane & GE & $\mathbf{U}$ & 1 & & 200 & & & $\mu g / \mathrm{L}$ \\
\hline Alkalinity & GE & $\mathrm{v}$ & 26 & & & & & $\mathrm{mg} / \mathrm{L}$ \\
\hline Aluminum & GE & & 856 & & & & 76800 & $\mu g / L$ \\
\hline Americium-241 & GP & $\mathbf{U}$ & 1 & & 6.34 & & & $\mathrm{pCi} / \mathrm{L}$ \\
\hline Ammonia nitrogen & GE & & 1.08 & & & & & $\mathrm{mg} / \mathrm{L}$ \\
\hline Antimony & GE & U & 2 & & 5 & & & $\mu g / L$ \\
\hline Antimony-125 & GP & U & 20 & & 300 & & & $\mathrm{pCi} / \mathrm{L}$ \\
\hline Arsenic & GE & U & 2 & & 50 & $\mathbf{U}$ & 3 & $\mu \mathrm{g} / \mathrm{L}$ \\
\hline Barium & GE & & 94.6 & & 2000 & & & $\mu g / L$ \\
\hline Beryllium & GE & U & 3 & & 1 & & & $\mu g / L$ \\
\hline Cadmium & $\mathrm{GE}$ & U & 2 & & 5 & $\mathbf{U}$ & 6 & $\mu g / L$ \\
\hline Calcium & GE & & 1510 & & & & & $\mu g / L$ \\
\hline Carbon tetrachloride & GE & U & 1 & & 5 & & & $\mu \mathrm{g} / \mathrm{L}$ \\
\hline Cerium-144 & GP & U & 60 & & 261 & & & $\mathrm{pCi} / \mathrm{L}$ \\
\hline Cesium-134 & GP & U & 10 & & 81.3 & & 0.6 & $\mathrm{pCi} / \mathrm{L}$ \\
\hline Cesium-137 & GP & U & 10 & & 200 & & 1.7 & $\mathrm{pCi} / \mathrm{L}$ \\
\hline Chloride & $\mathrm{GE}$ & & 3.2 & & & & 1.9 & $\mathrm{mg} / \mathrm{L}$ \\
\hline Chloroform & $\mathrm{GE}$ & U & 1 & & 100 & & & $\mu g / L$ \\
\hline Chromium & GE & $\mathbf{U}$ & 4 & & 100 & $\mathrm{U}$ & 3 & $\mu g / L$ \\
\hline Cobalt-57 & GP & $\mathbf{U}$ & 10 & & 1000 & & & $\mathrm{pCi} / \mathrm{L}$ \\
\hline Cobalt- 60 & GP & U & 10 & & 100 & & 5.1 & $\mathrm{pCi} / \mathrm{L}$ \\
\hline Copper & $\mathrm{GE}$ & U & 4 & & 1300 & & 60 & $\mu g / L$ \\
\hline Curium-242 & GP & U & 1 & & 0.133 & & & $\mathrm{pCi} / \mathrm{L}$ \\
\hline Curium-243,244 & $\mathbf{G P}$ & U & 1 & & 8.3 & & & $\mathrm{pCi} / \mathrm{L}$ \\
\hline Europium-152 & GP & $\mathbf{U}$ & 40 & & & & & $\mathrm{pCi} / \mathrm{L}$ \\
\hline Europium-154 & GP & $\mathbf{U}$ & 20 & & 200 & & & $\mathrm{pCi} / \mathrm{L}$ \\
\hline Europium-155 & GP & U & 30 & & 600 & & & $\mathrm{pCi} / \mathrm{L}$ \\
\hline Fluoride & GE & $\mathbf{U}$ & 0.1 & & 4 & & & $\mathrm{mg} / \mathrm{L}$ \\
\hline Gross alpha & GE & & 4.8 & 2.4 & 15 & & 4.9 & $\mathrm{pCi} / \mathrm{L}$ \\
\hline Hardness & $\mathrm{GE}$ & & 11 & & & & 3400 & $\mathrm{mg} / \mathrm{L}$ \\
\hline Iodine- 129 & $\mathrm{TE}$ & & 4.2 & 1.3 & 1 & & 130 & $\mathrm{pCi} / \mathrm{L}$ \\
\hline Iron & GE & & 7140 & & 300 & & & $\mu \mathrm{g} / \mathrm{L}$ \\
\hline Lead & GE & $\mathbf{U}$ & 3 & & 15 & & 3.3 & $\mu \mathrm{g} / \mathrm{L}$ \\
\hline Magnesium & GE & & 1750 & & & & & $\mu \mathrm{g} / \mathrm{L}$ \\
\hline Manganese & GE & J2 & 3100 & & 50 & & & $\mu g / L$ \\
\hline Manganese- 54 & GP & $\mathbf{U}$ & 10 & & 300 & & & $\mathrm{pCi} / \mathrm{L}$ \\
\hline Mercury & GE & & 0.24 & & 2 & $\mathbf{U}$ & 0.2 & $\mu \mathrm{g} / \mathrm{L}$ \\
\hline Neptunium-237 & TE & $\mathbf{U}$ & 10 & & 7.06 & $\mathbf{U}$ & 1 & $\mathrm{pCi} / \mathrm{L}$ \\
\hline Nickel & GE & $\mathbf{U}$ & 4 & & 100 & $\mathbf{U}$ & 34 & $\mu \mathrm{g} / \mathrm{L}$ \\
\hline Nitrate as nitrogen & GE & & 0.29 & & 10 & & 1090 & $\mathrm{mg} / \mathrm{L}$ \\
\hline Nonvolatile beta & $\mathrm{GE}$ & & 75.6 & 4.8 & 50 & & 94 & $\mathrm{pCi} / \mathrm{L}$ \\
\hline Plutonium-238 & GP & $\mathbf{U}$ & 1 & & 7.02 & $\mathbf{U}$ & 1 & $\mathrm{pCi} / \mathrm{L}$ \\
\hline Plutonium-239,240 & GP & $\mathbf{U}$ & 1 & & 62.1 & U & 1 & $\mathrm{pCi} / \mathrm{L}$ \\
\hline Potassium & $G E$ & & 3960 & & & & & $\mu \mathrm{g} / \mathrm{L}$ \\
\hline Potassium-40 & GP & $\mathbf{U}$ & 110 & & 300 & & & $\mathrm{pCi} / \mathrm{L}$ \\
\hline Promethium-144 & GP & $\mathbf{U}$ & 10 & & & & & $\mathrm{pCi} / \mathrm{L}$ \\
\hline
\end{tabular}


(Table 21. Continued)

\begin{tabular}{|c|c|c|c|c|c|c|c|c|}
\hline \multirow[b]{2}{*}{ Analyte } & \multirow[b]{2}{*}{ Lab } & \multicolumn{3}{|c|}{$7 / 92$} & \multirow[b]{2}{*}{ Standard } & \multicolumn{3}{|c|}{1989} \\
\hline & & Mod & Result & $A \propto c$ & & Mod & Result & Units \\
\hline Promethium-146 & GP & $\bar{U}$ & 10 & & & & & $\mathrm{pCi} / \mathrm{L}$ \\
\hline Radium-226 & GP & & 1.69 & 0.3 & 15.7 & & 48 & $\mathrm{pCi} / \mathrm{L}$ \\
\hline Radium-228 & GP & & 14 & 2.7 & 7.85 & & & $\mathrm{pCi} / \mathrm{L}$ \\
\hline Ruthenium-106 & GP & U & 90 & & 30 & & & $\mathrm{pCi} / \mathrm{L}$ \\
\hline Selenium & GE & $\mathbf{U}$ & 2 & & 50 & U & 2 & $\mu g / L$ \\
\hline Silver & $\mathrm{GE}$ & $\mathbf{U}$ & 2 & & 50 & U & 4 & $\mu g / L$ \\
\hline Sodium & $\mathrm{GE}$ & & 2440 & & & & 105000 & $\mu \mathrm{g} / \mathrm{L}$ \\
\hline Sodium-22 & GP & $\mathbf{U}$ & 10 & & 466 & & & $\mathrm{pCi} / \mathrm{L}$ \\
\hline Strontium-90 & GP & & 22.7 & 2 & 8 & & 370 & $\mathrm{pCi} / \mathrm{L}$ \\
\hline Technetium-99 & GP & $\mathrm{U}$ & 300 & & 900 & & 330 & $\mathrm{pC} / \mathrm{L}$ \\
\hline Tetrachloroethylene & GE & $\mathrm{U}$ & 1 & & 5 & & & $\mu \mathrm{g} / \mathrm{L}$ \\
\hline Thallium & GE & $\mathbf{U}$ & 2 & & 1 & & & $\mu \mathrm{g} / \mathrm{L}$ \\
\hline Thorium-228 & GP & $\mathrm{U}$ & 1 & & 125 & & & $\mathrm{pCi} / \mathrm{L}$ \\
\hline Thorium-230 & GP & & 1.6 & 0.26 & 79.2 & & & $\mathrm{pCi} / \mathrm{L}$ \\
\hline Thorium-232 & GP & U & 1 & & 88 & & & $\mathrm{pCi} / \mathrm{L}$ \\
\hline Tin & $\mathrm{GE}$ & & 3.42 & & & & & $\mu \mathrm{g} / \mathrm{L}$ \\
\hline Total organic carbon & GE & & 50 & & & & & $\mathrm{mg} / \mathrm{L}$ \\
\hline Total organic halogens & GE & & 30.9 & & & & & $\mu \mathrm{g} / \mathrm{L}$ \\
\hline Total phenols & GE & & 6.9 & & & & & $\mu g / L$ \\
\hline Trichloroethylene & GE & $\mathbf{U}$ & 1 & & 5 & & & $\mu g / L$ \\
\hline Tritium & GE & & 28.9 & 1 & 20 & & 12000 & $\mathrm{pCi} / \mathrm{ml}$ \\
\hline Uranium-234 & GP & $\mathrm{U}$ & 1 & & 13.9 & & & $\mathrm{pCi} / \mathrm{L}$ \\
\hline Uranium-235 & GP & $\mathbf{U}$ & 1 & & 14.5 & & & $\mathrm{pCi} / \mathrm{L}$ \\
\hline Uranium-238 & GP & $\mathrm{U}$ & 1 & & 14.6 & & 95 & $\mathrm{pCi} / \mathrm{L}$ \\
\hline Vanadium & GE & $\mathrm{U}$ & 8 & & & & & $\mu g / L$ \\
\hline Yttrium-88 & GP & $\mathrm{U}$ & 60 & & & & & $\mathrm{pCi} / \mathrm{L}$ \\
\hline Zinc & GE & & 94.1 & & 5000 & & 120 & $\mu g / L$ \\
\hline Zinc -65 & GP & $\mathrm{U}$ & 20 & & 300 & & & $\mathrm{pCi} / \mathrm{L}$ \\
\hline
\end{tabular}


Table 22. FSP032 Laboratory Analyses

Field Measurements:

Sample Date: 07/28/92

pH: 4.10

Specific Conductance: $95 \mu \mathrm{S} / \mathrm{cm}$

\begin{tabular}{|c|c|c|c|c|c|c|c|c|}
\hline \multirow{2}{*}{ Analyte } & \multirow[b]{2}{*}{ Lab } & \multicolumn{3}{|c|}{$7 / 92$} & \multirow[b]{2}{*}{ Standard } & \multicolumn{3}{|c|}{1989} \\
\hline & & Mod & Result & $A \propto c$ & & Mod & Result & Units \\
\hline 1,1,1-Trichloroethane & $\mathrm{GE}$ & $\mathbf{U}$ & 1 & & 200 & & & $\mu \mathrm{g} / \mathrm{L}$ \\
\hline Alkalinity & GE & $\mathrm{V}$ & 1.55 & & & & & $\mathrm{mg} / \mathrm{L}$ \\
\hline Aluminum & GE & & 936 & & & & 86900 & $\mu g / L$ \\
\hline Americium-241 & GP & $\mathbf{U}$ & 1 & & 6.34 & & & $\mathrm{pCi} / \mathrm{L}$ \\
\hline Ammonia nitrogen & GE & U & 0.1 & & & & & $\mathrm{mg} / \mathrm{L}$ \\
\hline Antimony & GE & U & 2 & & 5 & & & $\mu g / L$ \\
\hline Antimony-125 & GP & $\mathbf{U}$ & 20 & & 300 & & & $\mathrm{pCi} / \mathrm{L}$ \\
\hline Arsenic & GE & $\mathbf{U}$ & 2 & & 50 & $\mathrm{U}$ & 3 & $\mu \mathrm{g} / \mathrm{L}$ \\
\hline Barium & GE & & 101.5 & & 2000 & & & $\mu g / L$ \\
\hline Beryllium & GE & $\mathbf{U}$ & 3 & & 1 & & & $\mu g / L$ \\
\hline Cadmium & GE & $\mathbf{U}$ & 2 & & 5 & $\mathrm{U}$ & 6 & $\mu \mathrm{g} / \mathrm{L}$ \\
\hline Calcium & GE & & 1215 & & & & & $\mu g / L$ \\
\hline Carbon tetrachloride & GE & U & 1 & & 5 & & & $\mu \mathrm{g} / \mathrm{L}$ \\
\hline Cerium-144 & GP & $\mathrm{U}$ & 60 & & 261 & & & $\mathrm{pCi} / \mathrm{L}$ \\
\hline Cesium-134 & GP & $\mathrm{U}$ & 10 & & 81.3 & $\mathrm{U}$ & 6.5 & $\mathrm{pCi} / \mathrm{L}$ \\
\hline Cesium-137 & GP & $\mathbf{U}$ & 10 & & 200 & & 5.6 & $\mathrm{pCi} / \mathrm{L}$ \\
\hline Chloride & GE & & 2.43 & & & & 2 & $\mathrm{mg} / \mathrm{L}$ \\
\hline Chloroform & GE & $\mathbf{U}$ & 1 & & 100 & & & $\mu \mathrm{g} / \mathrm{L}$ \\
\hline Chromium & GE & $\mathrm{U}$ & 4 & & 100 & $\mathrm{U}$ & 3 & $\mu \mathrm{g} / \mathrm{L}$ \\
\hline Cobalt-57 & GP & $\mathrm{U}$ & 10 & & 1000 & & & $\mathrm{pCi} / \mathrm{L}$ \\
\hline Cobalt- 60 & GP & $\mathbf{U}$ & 10 & & 100 & & 6.1 & $\mathrm{pCi} / \mathrm{L}$ \\
\hline Copper & GE & $U$ & 4 & & 1300 & & 60 & $\mu \mathrm{g} / \mathrm{L}$ \\
\hline Curium-242 & GP & $\mathbf{U}$ & 1 & & 0.133 & & & $\mathrm{pCi} / \mathrm{L}$ \\
\hline Curium-243,244 & GP & $\mathbf{U}$ & 1 & & 8.3 & & & $\mathrm{pCi} / \mathrm{L}$ \\
\hline Europium-152 & GP & $\mathbf{U}$ & 40 & & & & & $\mathrm{pCi} / \mathrm{L}$ \\
\hline Europium-154 & GP & $\mathrm{U}$ & 20 & & 200 & & & $\mathrm{pCi} / \mathrm{L}$ \\
\hline Europium-155 & GP & $\mathbf{U}$ & 30 & & 600 & & & $\mathrm{pCi} / \mathrm{L}$ \\
\hline Fluoride & GE & & 0.181 & & 4 & & & $\mathrm{mg} / \mathrm{L}$ \\
\hline Gross alpha & GE & & 5.1 & 2.7 & 15 & & 1800 & $\mathrm{pCi} / \mathrm{L}$ \\
\hline Hardness & GE & & 11 & & & & 1500 & $\mathrm{mg} / \mathrm{L}$ \\
\hline Iodine-129 & $\mathrm{TE}$ & & 2.8 & 1.5 & 1 & & 370 & $\mathrm{pCi} / \mathrm{L}$ \\
\hline Iron & $\mathrm{GE}$ & & 226.5 & & 300 & & & $\mu g / L$ \\
\hline Lead & GE & $\mathbf{U}$ & 3 & & 15 & & 4.3 & $\mu \mathrm{g} / \mathrm{L}$ \\
\hline Magnesium & GE & & 1075 & & & & & $\mu \mathrm{g} / \mathrm{L}$ \\
\hline Manganese & GE & J2 & 1415 & & 50 & & & $\mu g / L$ \\
\hline Manganese-54 & GP & $\mathbf{U}$ & 10 & & 300 & & & $\mathrm{pCi} / \mathrm{L}$ \\
\hline Mercury & $\mathrm{GE}$ & $\mathrm{U}$ & 0.2 & & 2 & $\mathbf{U}$ & 0.2 & $\mu g / L$ \\
\hline Neptunium-237 & $\mathrm{TE}$ & $\mathrm{U}$ & 10 & & 7.06 & $\mathrm{U}$ & 1 & $\mathrm{pCi} / \mathrm{L}$ \\
\hline Nickel & $\mathrm{GE}$ & $\mathrm{U}$ & 4 & & 100 & & 60 & $\mu g / L$ \\
\hline Nitrate as nitrogen & GE & & 9.5 & & 10 & & 1130 & $\mathrm{mg} / \mathrm{L}$ \\
\hline Nonvolatile beta & GE & & 168 & 7 & 50 & & 2800 & $\mathrm{pCi} / \mathrm{L}$ \\
\hline Plutonium-238 & GP & $U$ & 1 & & 7.02 & $\mathrm{U}$ & 1 & $\mathrm{pCi} / \mathrm{L}$ \\
\hline Plutonium-239,240 & GP & $\mathrm{U}$ & 1 & & 62.1 & $\mathrm{U}$ & 1 & $\mathrm{pCi} / \mathrm{L}$ \\
\hline Potassium & GE & $\mathbf{U}$ & 500 & & & & & $\mu g / L$ \\
\hline Potassium-40 & GP & $\mathbf{U}$ & 110 & & 300 & & . & $\mathrm{pCi} / \mathrm{L}$ \\
\hline Promethium-144 & GP & $\mathbf{U}$ & 10 & & & & & $\mathrm{pCi} / \mathrm{L}$ \\
\hline
\end{tabular}


(Table 22. Continued)

\begin{tabular}{|c|c|c|c|c|c|c|c|c|}
\hline \multirow{2}{*}{ Analyte } & \multicolumn{5}{|c|}{$7 / 92$} & \multicolumn{3}{|c|}{1989} \\
\hline & Lab & Mod & Result & Ace & Standard & Mod & Result & Units \\
\hline Promethium-146 & GP & $\mathrm{U}$ & 10 & & & & & $\mathrm{pCi} / \mathrm{L}$ \\
\hline Radium-226 & GP & U & 1 & & 15.7 & & 72 & $\mathrm{pCi} / \mathrm{L}$ \\
\hline Radium-228 & GP & & 10.6 & 1.1 & 7.85 & & & $\mathrm{pCi} / \mathrm{L}$ \\
\hline Rutbenium-106 & GP & $\mathbf{U}$ & 90 & & 30 & & & $\mathrm{pCi} / \mathrm{L}$ \\
\hline Selenium & $\mathrm{GE}$ & $\mathrm{U}$ & 2 & & 50 & U & 2 & $\mu \mathrm{g} / \mathrm{L}$ \\
\hline Silver & $\mathrm{GE}$ & $\mathrm{U}$ & 2 & & 50 & & 12 & $\mu g / L$ \\
\hline Sodium & GE & & 4490 & & & & 118000 & $\mu g / L$ \\
\hline Sodium-22 & GP & $\mathrm{U}$ & 10 & & 466 & & & $\mathrm{pCi} / \mathrm{L}$ \\
\hline Strontium-90 & GP & & 124 & 4 & 8 & & 350 & $\mathrm{pCi} / \mathrm{L}$ \\
\hline Technetium-99 & GP & & 1650 & 66 & 900 & & 1200 & $\mathrm{pCi} / \mathrm{L}$ \\
\hline Tetrachloroethylene & GE & $\mathrm{U}$ & 1 & & 5 & & & $\mu g / L$ \\
\hline Thallium & GE & $\mathrm{U}$ & 2 & & 1 & & & $\mu g / L$ \\
\hline Thorium-228 & GP & $\mathrm{U}$ & 1 & & 125 & & & $\mathrm{pCi} / \mathrm{L}$ \\
\hline Thorium-230 & GP & $\mathrm{U}$ & 1 & & 79.2 & & & $\mathrm{pCi} / \mathrm{L}$ \\
\hline Thorium-232 & GP & $\mathrm{U}$ & 1 & & 88 & & & $\mathrm{pCi} / \mathrm{L}$ \\
\hline Tin & GE & $\mathrm{U}$ & 2 & & & & & $\mu g / L$ \\
\hline Total organic carbon & GE & & 3 & & & & & $\mathrm{mg} / \mathrm{L}$ \\
\hline Total organic halogens & GE & $\mathrm{U}$ & 5 & & & & & $\mu g / L$ \\
\hline Total phenols & GE & $\mathrm{U}$ & 5 & & & & & $\mu g / L$ \\
\hline Trichloroethylene & GE & $\mathrm{U}$ & 1 & & 5 & & & $\mu g / L$ \\
\hline Tritium & GE & & 730 & 4 & 20 & & 15000 & $\mathrm{pCi} / \mathrm{ml}$ \\
\hline Uranium-234 & GP & & 2.32 & 0.61 & 13.9 & & & $\mathrm{pCi} / \Omega$ \\
\hline Uranium-235 & GP & $\mathrm{U}$ & 1 & & 14.5 & & & $\mathrm{pCi} / \mathrm{L}$ \\
\hline Uranium-238 & GP & & 1.695 & 0.5 & 14.6 & & 96 & $\mathrm{pCi} / \mathrm{L}$ \\
\hline Vanadium & GE & $U$ & 8 & & & & & $\mu g / L$ \\
\hline Yttrium-88 & GP & U & 60 & & & & & $\mathrm{pCi} / \mathrm{L}$ \\
\hline Zinc & GE & & 140 & & 5000 & & 160 & $\mu g / L$ \\
\hline Zinc-65 & GP & $\mathbf{U}$ & 20 & & 300 & & & $\mathrm{pCi} / \mathrm{L}$ \\
\hline
\end{tabular}


Table 23. FSP047 Laboratory Analyses

Field Measurements:

Sample Date: 07/28/92

pH: 5.38

Specific Conductance: $88 \mu \mathrm{S} / \mathrm{cm}$.

\begin{tabular}{|c|c|c|c|c|c|c|c|c|}
\hline Analyte & Lab & Mod & $\begin{array}{c}7 / 92 \\
\text { Result }\end{array}$ & $A \infty$ & Standard & Mod & $\begin{array}{c}1989 \\
\text { Result } \\
\end{array}$ & Units \\
\hline 1,1,1-Trichloroethane & $\mathrm{GE}$ & $\mathbf{U}$ & 1 & & 200 & & & $\mu g / L$ \\
\hline 1,1,1-Trichloroethane & WA & $\mathbf{U}$ & 1 & & 200 & & & $\mu g / L$ \\
\hline Alkalinity & GE & $\mathrm{V}$ & 14.1 & & & & & $\mathrm{mg} / \mathrm{L}$ \\
\hline Aluminum & $\mathrm{GE}$ & & 224 & & & & 130 & $\mu g / L$ \\
\hline Aluminum & WA & & 316 & & & & & $\mu g / L$ \\
\hline Americium-241 & GP & U & 1 & & 6.34 & & & $\mathrm{pCi} / \mathrm{L}$ \\
\hline Americium-241 & $\mathrm{CN}$ & $\mathbf{U}$ & 1 & & 6.34 & & & $\mathrm{pCi} / \mathrm{L}$ \\
\hline Antimony & GE & $\mathrm{U}$ & 2 & & 5 & & & $\mu g / L$ \\
\hline Antimony & WA & $\mathbf{U}$ & 2.6 & & 5 & & & $\mu \mathrm{g} / \mathrm{L}$ \\
\hline Antimony-125 & GP & $\mathbf{U}$ & 20 & & 300 & & & $\mathrm{pCi} / \mathrm{L}$ \\
\hline Antimony-125 & $\mathrm{CN}$ & $\mathbf{U}$ & 20 & & 300 & & & $\mathrm{pCi} / \mathrm{L}$ \\
\hline Arsenic & GE & & 2.19 & & 50 & $\mathrm{U}$ & 3 & $\mu g / L$ \\
\hline Arsenic & WA & $\mathrm{J} 3$ & 4.1 & & 50 & & & $\mu g / L$ \\
\hline Barium & GE & & 48.8 & & 2000 & & & $\mu g / L$ \\
\hline Barium & WA & & 52.6 & & 2000 & & & $\mu \mathrm{g} / \mathrm{L}$ \\
\hline Beryllium & GE & $\mathrm{U}$ & 3 & & 1 & & & $\mu \mathrm{g} / \mathrm{L}$ \\
\hline Beryllium & WA & $\mathbf{U}$ & 0.18 & & 1 & & & $\mu g / L$ \\
\hline Cadmium & $\mathrm{GE}$ & $\mathbf{U}$ & 2 & & 5 & & 1.7 & $\mu g / L$ \\
\hline Cadmium & WA & $\mathbf{U}$ & 0.35 & & 5 & & & $\mu \mathrm{g} / \mathrm{L}$ \\
\hline Calcium & $\mathrm{GE}$ & & 491 & & & & & $\mu \mathrm{g} / \mathrm{L}$ \\
\hline Calcium & WA & & 595 & & & & & $\mu \mathrm{g} / \mathrm{L}$ \\
\hline Carbon tetrachloride & GE & $\mathrm{U}$ & 1 & & 5 & & & $\mu \mathrm{g} / \mathrm{L}$ \\
\hline Carbon tetrachloride & WA & $\mathbf{U}$ & 1 & & 5 & & & $\mu g / L$ \\
\hline Carbon tetrachloride & WA & $\mathbf{U}$ & 1 & & 5 & & & $\mu g / L$ \\
\hline Cerium-144 & GP & $\mathbf{U}$ & 60 & & 261 & & & $\mathrm{pCi} / \mathrm{L}$ \\
\hline Cerium-144 & $\mathrm{CN}$ & $\mathbf{U}$ & 50 & & 261 & & & $\mathrm{pCi} / \mathrm{L}$ \\
\hline Cesium-134 & GP & $\mathbf{U}$ & 10 & & 81.3 & $\mathbf{U}$ & 71 & $\mathrm{pCi} / \mathrm{L}$ \\
\hline Cesium-134 & $\mathrm{CN}$ & $\mathbf{U}$ & 10 & & 81.3 & & & $\mathrm{pCi} / \mathrm{L}$ \\
\hline Cesium-137 & GP & $\mathbf{U}$ & 10 & & 200 & $\mathbf{U}$ & 13 & $\mathrm{pCi} / \mathrm{L}$ \\
\hline Cesium-137 & $\mathrm{CN}$ & $\mathbf{U}$ & 10 & & 200 & & & $\mathrm{pCi} / \mathrm{L}$ \\
\hline Chloride & GE & & 6.52 & & & & 3.8 & $\mathrm{mg} / \mathrm{L}$ \\
\hline Chloride & WA & & 6.06 & & & & & $\mathrm{mg} / \mathrm{L}$ \\
\hline Chloroform & GE & $\mathbf{U}$ & 1 & & 100 & & & $\mu g / L$ \\
\hline Chloroform & WA & $\mathbf{U}$ & 1 & & 100 & & & $\mu \mathrm{g} / \mathrm{L}$ \\
\hline Chloroform & WA & $\mathbf{U}$ & 1 & & 100 & $\mathrm{U}$ & 3 & $\mu g / L$ \\
\hline Chromium & GE & $\mathbf{U}$ & 4 & & 100 & & & $\mu g / L$ \\
\hline Chrómium & WA & J3 & 2.8 & & 100 & & & $\mu g / L$ \\
\hline Cobalt-57 & GP & $\mathbf{U}$ & 10 & & 1000 & & & $\mathrm{pCi} / \mathrm{L}$ \\
\hline Cobalt-57 & $\mathrm{CN}$ & $\mathbf{U}$ & 10 & & 1000 & & & $\mathrm{pCi} / \mathrm{L}$ \\
\hline Cobalt -60 . & GP & $\mathbf{U}$ & 10 & & 100 & & 130 & $\mathrm{pCi} / \mathrm{L}$ \\
\hline Cobalt -60 & $\mathrm{CN}$ & $\mathbf{U}$ & 10 & & 100 & & & $\mathrm{pCi} / \mathrm{L}$ \\
\hline Copper & $\mathrm{GE}$ & $\mathbf{U}$ & 4 & & 1300 & $\mathrm{U}$ & 7 & $\mu g / L$ \\
\hline Copper & WA & UV & 1.1 & & 1300 & & & $\mu g / L$ \\
\hline Curium-242 & GP & $\mathrm{U}$ & 1 & & 0.133 & & & $\mathrm{pCi} / \mathrm{L}$ \\
\hline Curium-242 & $\mathrm{CN}$ & $\mathrm{U}$ & 1 & & 0.133 & & & $\mathrm{pCi} / \mathrm{L}$ \\
\hline Curium-243,244 & GP & U & 1 & & 8.3 & & & $\mathrm{pCi} / \mathrm{L}$ \\
\hline
\end{tabular}


(Table 23. Continued)

\begin{tabular}{|c|c|c|c|c|c|c|c|c|}
\hline \multirow{2}{*}{ Analyte } & \multicolumn{5}{|c|}{$7 / 92$} & \multicolumn{3}{|c|}{1989} \\
\hline & Lab & Mod & Result & $A \propto c$ & Standard & Mod & Result & Units \\
\hline Curium-243,244 & $\mathrm{CN}$ & $\bar{U}$ & 1 & & 8.3 & & . & $\overline{\mathrm{pCi} / \mathrm{L}}$ \\
\hline Europium-152 & GP & $\mathbf{U}$ & 40 & & & & & $\mathrm{pCi} / \mathrm{L}$ \\
\hline Europium-152 & $\mathrm{CN}$ & $\mathrm{U}$ & 40 & & & & & $\mathrm{pCi} / \mathrm{L}$ \\
\hline Europium-154 & GP & $\mathrm{U}$ & 20 & & 200 & & & $\mathrm{pCi} / \mathrm{L}$ \\
\hline Europium-154 & $\mathrm{CN}$ & $\mathbf{U}$ & 25 & & 200 & & & $\mathrm{pCi} / \mathrm{L}$ \\
\hline Europium-155 & GP & $\mathbf{U}$ & 30 & & 600 & & & $\mathrm{pCi} / \mathrm{L}$ \\
\hline Europium-155 & $\mathrm{CN}$ & U & 25. & & 600 & & & $\mathrm{pCi} / \mathrm{L}$ \\
\hline Fluoride & GE & U & 0.1 & & 4 & & & $\mathrm{mg} / \mathrm{L}$ \\
\hline Fluoride & WA & $\mathrm{U}$ & 0.1 & & 4 & & & $\mathrm{mg} / \mathrm{L}$ \\
\hline Gross alpha & $\mathrm{GE}$ & & 2.2 & 1.8 & 15 & & 350 & $\mathrm{pCi} / \mathrm{L}$ \\
\hline Gross alpha & $\mathrm{TM}$ & & 7.2 & 5.3 & 15 & & & $\mathrm{pCi} / \mathrm{L}$ \\
\hline Hardness & GE & & 7.79 & & & & 117 & $\mathrm{mg} / \mathrm{L}$ \\
\hline Iodine-129 & $\mathrm{TE}$ & $\mathbf{U}$ & 2 & & 1 & & & $\mathrm{pCi} / \mathrm{L}$ \\
\hline Iodine-129 & $\mathrm{CN}$ & $\mathbf{U}$ & 2 & & 1 & & 410 & $\mathrm{pCi} / \mathrm{L}$ \\
\hline Iron & $\mathrm{GE}$ & & 12000 & & 300 & & & $\mu g / L$ \\
\hline Iron & WA & $\mathrm{V}$ & 13000 & & 300 & & & $\mu g / L$ \\
\hline Lead & $\mathrm{GE}$ & $\mathbf{U}$ & 3 & & 15 & U & 3 & $\mu g / L$ \\
\hline Lead & WA & $\mathrm{J} 3 \mathrm{~V}$ & 4.1 & & 15 & & & $\mu g / L$ \\
\hline Magnesium & $G E$ & & 1590 & & & & & $\mu g / L$ \\
\hline Magnesium & WA & $\mathrm{v}$ & 1650 & & & & & $\mu g / L$ \\
\hline Manganese & GE & & 862 & & 50 & & & $\mu g / L$ \\
\hline Manganese & WA & & 886 & & 50 & & & $\mu \mathrm{g} / \mathrm{L}$ \\
\hline Manganese-54 & GP & $\mathrm{U}$ & 10 & & 300 & & & $\mathrm{pCi} / \mathrm{L}$ \\
\hline Manganese- 54 & $\mathrm{CN}$ & $\mathrm{U}$ & 10 & & 300 & & & $\mathrm{pCi} / \mathrm{L}$ \\
\hline Mercury & $G E$ & & 0.47 & & 2 & $\mathrm{U}$ & 0.2 & $\mu \mathrm{g} / \mathrm{L}$ \\
\hline Mercury & WA & & 0.5985 & & 2 & & & $\mu \mathrm{g} / \mathrm{L}$ \\
\hline Neptunium-237 & $\mathrm{TE}$ & $\mathbf{U}$ & 10 & & 7.06 & $\mathrm{U}$ & 1 & $\mathrm{pCi} / \mathrm{L}$ \\
\hline Neptunium-237 & $\mathrm{CN}$ & $\mathrm{U}$ & 45 & & 7.06 & & & $\mathrm{pCi} / \mathrm{L}$ \\
\hline Neptunium-237 & $\mathrm{CN}$ & $\mathrm{U}$ & 1 & & 7.06 & $\mathrm{U}$ & 34 & $\mathrm{pCi} / \mathrm{L}$ \\
\hline Nickel & GE & $\mathbf{U}$ & 4 & & 100 & & & $\mu \mathrm{g} / \mathrm{L}$ \\
\hline Nickel & WA & $U$ & 3.1 & & 100 & & & $\mu \mathrm{g} / \mathrm{L}$ \\
\hline Nitrate as nitrogen & GE & & 0.52 & & 10 & & 177 & $\mathrm{mg} / \mathrm{L}$ \\
\hline Nitrate as nitrogen & WA & & 0.193 & & 10 & & & mglL \\
\hline Nonvolatile beta & GE & & 49.2 & 3.9 & 50 & & 4600 & $\mathrm{pCi} / \mathrm{L}$ \\
\hline Nonvolatile beta & $\mathrm{TM}$ & $\mathrm{V}$ & 67.65 & 9.9 & 50 & & & $\mathrm{pCi} / \mathrm{L}$ \\
\hline Plutonium-238 & GP & $\mathbf{U}$ & 1 & & 7.02 & $\mathbf{U}$ & 1 & $\mathrm{pCi} / \mathrm{L}$ \\
\hline Plutonium-238 & $\mathrm{CN}$ & $\mathrm{U}$ & 1 & & 7.02 & & & $\mathrm{pCi} / \mathrm{L}$ \\
\hline Plutonium-239,240 & GP & $\mathrm{U}$ & 1 & & 62.1 & $\mathrm{U}$ & 1 & $\mathrm{pCi} / \mathrm{L}$ \\
\hline Plutonium-239,240 & $\mathrm{CN}$ & $\mathbf{U}$ & 1 & & 62.1 & & & $\mathrm{pCi} / \mathrm{L}$ \\
\hline Potassium & $\mathrm{GE}$ & $\mathbf{U}$ & 500 & & & & & $\mu g / L$ \\
\hline Potassium & WA & & 625 & & & & & $\mu g / L$ \\
\hline Potassium -40 & GP & $\mathbf{U}$ & 110 & & 300 & & & $\mathrm{pCi} / \mathrm{L}$ \\
\hline Potassium -40 & $\mathrm{CN}$ & $\mathrm{U}$ & 175 & & 300 & & & $\mathrm{pCi} / \mathrm{L}$ \\
\hline Promethium-144 & GP & $\mathbf{U}$ & 10 & & & & & $\mathrm{pCi} / \mathrm{L}$ \\
\hline Promethium-144 & $\mathrm{CN}$ & $\mathbf{U}$ & 10 & & & & & $\mathrm{pCi} / \mathrm{L}$ \\
\hline Promethium-146 & GP & $\mathbf{U}$ & 10 & & & & & $\mathrm{pCi} / \mathrm{L}$ \\
\hline Promethium-146 & $\mathrm{CN}$ & $\mathbf{U}$ & 20 & & & & & $\mathrm{pCi} / \mathrm{L}$ \\
\hline Radium-226 & GP & $\mathbf{U}$ & 1 & & 15.7 & & 430 & $\mathrm{pCi} / \mathrm{L}$ \\
\hline Radium-226 & $\mathrm{CN}$ & $\mathbf{U}$ & 175 & & 15.7 & & & $\mathrm{pCi} / \mathrm{L}$ \\
\hline
\end{tabular}


(Table 23. Continued)

\begin{tabular}{|c|c|c|c|c|c|c|c|c|}
\hline Analyte & Lab & Mod & $\begin{array}{c}7 / 92 \\
\text { Result }\end{array}$ & $A \propto c$ & Standard & Mod & $\begin{array}{c}1989 \\
\text { Result }\end{array}$ & Units \\
\hline Radium-226 & $\mathrm{CN}$ & $\bar{U}$ & 1 & & 15.7 & & & $\mathrm{pCi} / \mathrm{L}$ \\
\hline Radium-228 & GP & & 12.6 & 1.6 & 7.85 & & & $\mathrm{pCi} / \mathrm{L}$ \\
\hline Radium-228 & $\mathrm{CN}$ & & 2.32 & 0.86 & 7.85 & & & $\mathrm{pCi} / \mathrm{L}$ \\
\hline Ruthenium-103 & $\mathrm{CN}$ & $\mathbf{U}$ & 10 & & & & & $\mathrm{pCi} / \mathrm{L}$ \\
\hline Ruthenium-106 & GP & $\mathbf{U}$ & 90 & & 30 & & & $\mathrm{pCi} / \mathrm{L}$ \\
\hline Ruthenium-106 & $\mathrm{CN}$ & U & 70 & & 30 & & & $\mathrm{pCi} / \mathrm{L}$ \\
\hline Selenium & $G E$ & $\mathbf{U}$ & 2 & & 50 & $\mathrm{U}$ & 2 & $\mu g / L$ \\
\hline Selenium & WA & $\mathbf{U}$ & 2 & & 50 & & & $\mu \mathrm{g} / \mathrm{L}$ \\
\hline Silver & $\mathrm{GE}$ & $\mathbf{U}$ & 2 & & 50 & $\mathrm{U}$ & 4 & $\mu g / L$ \\
\hline Silver & WA & UV & 0.7 & & 50 & & & $\mu g / L$ \\
\hline Sodium & $\mathrm{GE}$ & & 6690 & & & & 29700 & $\mu g / L$ \\
\hline Sodium & WA & & 7450 & & & & & $\mu g / L$ \\
\hline Sodium-22 & GP & $\mathbf{U}$ & 10 & & 466 & & & $\mathrm{pC} \mathrm{i} / \mathrm{L}$ \\
\hline Sodium-22 & $\mathrm{CN}$ & $\mathbf{U}$ & 10 & & 466 & & & $\mathrm{pCi} / \mathrm{L}$ \\
\hline Strontium-90 & $\mathrm{GP}$ & & 18.5 & 2.45 & 8 & & 3200 & $\mathrm{pCi} / \mathrm{L}$ \\
\hline Strontium-90 & $\mathrm{CN}$ & & 14.6 & 1.66 & 8 & & & $\mathrm{pCi} / \mathrm{L}$ \\
\hline Technetium-99 & GP & $\mathbf{U}$ & 300 & & 900 & & 22 & $\mathrm{pCi} / \mathrm{L}$ \\
\hline Technetium-99 & $\mathrm{CN}$ & $\mathbf{U}$ & 300 & & 900 & & & $\mathrm{pCi} / \mathrm{L}$ \\
\hline Tetrachloroethylene & $\mathrm{GE}$ & $\mathbf{U}$ & 1 & & 5 & & & $\mu \mathrm{g} / \mathrm{L}$ \\
\hline Tetrachloroethylene & WA & $U$ & 1 & & 5 & & & $\mu \mathrm{g} / \mathrm{L}$ \\
\hline Tetrachloroethylene & WA & $\mathbf{U}$ & 1 & & 5 & & 2900 & $\mu \mathrm{g} / \mathrm{L}$ \\
\hline Thallium & GE & $\mathrm{U}$ & 2 & & 1 & & & $\mu \mathrm{g} / \mathrm{L}$ \\
\hline Thallium & WA & $\mathrm{U}$ & 2 & & 1 & & & $\mu \mathrm{g} / \mathrm{L}$ \\
\hline Thorium-228 & GP & $\mathrm{U}$ & 1 & & 125 & & & $\mathrm{pCi} / \mathrm{L}$ \\
\hline Thorium-228 & $\mathrm{CN}$ & $\mathbf{U}$ & 1 & & 125 & & & $\mathrm{pC} \mathrm{i} / \mathrm{L}$ \\
\hline Thorium-228 & $\mathrm{CN}$ & $\mathbf{U}$ & 400 & & 125 & & & $\mathrm{pCi} / \mathrm{L}$ \\
\hline Thorium-230 & GP & & 1.15 & 0.21 & 79.2 & & & $\mathrm{pCi} / \mathrm{L}$ \\
\hline Thorium-230 & $\mathrm{CN}$ & $\mathrm{U}$ & 1 & & 79.2 & & & $\mathrm{pCi} / \mathrm{L}$ \\
\hline Thorium-232 & GP & $\mathrm{U}$ & 1 & & 88 & & & $\mathrm{pCi} / \mathrm{L}$ \\
\hline Thorium-232 & $\mathrm{CN}$ & $\mathrm{U}$ & 1 & & 88 & & & $\mathrm{pC} \mathrm{i} / \mathrm{L}$ \\
\hline Tin & $\mathrm{GE}$ & $\mathrm{U}$ & 2 & & & & & $\mu g / L$ \\
\hline Tin & WA & & 15 & & & & & $\mu g / L$ \\
\hline Total organic carbon & $\mathrm{GE}$ & & 20 & & & & & $\mathrm{mg} / \mathrm{L}$ \\
\hline Total organic carbon & WA & & 25.7 & & & & & $\mathrm{mg} / \mathrm{L}$ \\
\hline Total organic halogens & GE & & 8.6 & & & & & $\mu g / L$ \\
\hline Total organic halogens & WA & JQ & 5.7 & & & & & $\mu g / L$ \\
\hline Total phenols & GE & $\mathrm{U}$ & 5 & & & & & $\mu g / L$ \\
\hline Total phenols & WA & U & 5 & & • & & & $\mu g / L$ \\
\hline Trichloroethylene & $G E$ & U & 1 & & 5 & & & $\mu g / L$ \\
\hline Trichloroethylene & WA & $\mathbf{U}$ & 1 & & 5 & & & $\mu g / L$ \\
\hline Trichloroethylene & WA & $\mathbf{U}$ & 1 & & 5 & & & $\mu g / L$ \\
\hline Tritium & $\mathrm{GE}$ & & 94.2 & 1.6 & 20 & & & $\mathrm{pCi} / \mathrm{ml}$ \\
\hline Tritium & TM & & 95.2 & 16.9 & 20 & & & $\mathrm{pC} \mathrm{i} / \mathrm{L}$ \\
\hline Uranium-234 & GP & $\mathrm{U}$ & 1 & & 13.9 & & & $\mathrm{pCi} / \mathrm{L}$ \\
\hline Uranium-234 & $\mathrm{CN}$ & $\mathbf{U}$ & 1 & & 13.9 & & & $\mathrm{pCi} / \mathrm{L}$ \\
\hline Uranium-235 & $G P$ & $\mathrm{U}$ & 1 & & 14.5 & & & $\mathrm{pCi} / \mathrm{L}$ \\
\hline Uranium-235 & $\mathrm{CN}$ & $\mathbf{U}$ & 15 & & 14.5 & & & $\mathrm{pCi} / \mathrm{L}$ \\
\hline Uranium-235 & $\mathrm{CN}$ & $\mathbf{U}$ & 1 & & 14.5 & $\mathbf{U}$ & 1 & $\mathrm{pCi} / \mathrm{L}$ \\
\hline Uranium-238 & GP & $\mathbf{U}$ & 1 & & 14.6 & & & $\mathrm{pCi} / \mathrm{L}$ \\
\hline
\end{tabular}


(Table 23. Continued)

\begin{tabular}{|c|c|c|c|c|c|c|c|c|}
\hline Analyte & Lab & Mod & $\begin{array}{c}7 / 92 \\
\text { Result }\end{array}$ & Acc & Standard & Mod & $\begin{array}{c}1989 \\
\text { Result }\end{array}$ & Units \\
\hline Uranium-238 & $\mathrm{CN}$ & $\overline{\mathrm{U}}$ & 1 & & 14.6 & & & $\mathrm{pCi} / \mathrm{L}$ \\
\hline Vanadium & GE & $\mathbf{U}$ & 8 & & & & & $\mu g / L$ \\
\hline Vanadium & WA & $\mathrm{J} 3$ & 2.2 & & & & & $\mu g / L$ \\
\hline Ytrium-88 & GP & $\mathbf{U}$ & 60 & & & & & $\mathrm{pCi} / \mathrm{L}$ \\
\hline Yttrium-88 & CN & $\mathbf{U}$ & 10 & & & & & $\mathrm{pCi} / \mathrm{L}$ \\
\hline Zinc & $\mathrm{GE}$ & & 57.8 & & 5000 & & 160 & $\mu g / L$ \\
\hline Zinc & WA & & 83.2 & & 5000 & & & $\mu g / L$ \\
\hline Zinc-65 & GP & $\mathbf{U}$ & 20 & & 300 & & & $\mathrm{pCi} / \mathrm{L}$ \\
\hline Zinc-65 & $\mathrm{CN}$ & $\mathbf{U}$ & 20 & & 300 & & & $\mathrm{pCi} / \mathrm{L}$ \\
\hline
\end{tabular}


Table 24. FSP204 Laboratory Analyses

Field Measurements:

Sample Date: 07/28/92

pH: 5.35

Specific Conductance: $277 \mu \mathrm{S} / \mathrm{cm}$

\begin{tabular}{|c|c|c|c|c|c|c|c|c|}
\hline Analyte & Lab & Mod & $\begin{array}{c}7 / 92 \\
\text { Result } \\
\end{array}$ & $A \propto c$ & Standard & Mod & $\begin{array}{c}1989 \\
\text { Result }\end{array}$ & Units \\
\hline 1,1,1-Trichloroethane & $\overline{G E}$ & $\bar{U}$ & 1 & & 200 & & & $\mu \mathrm{g} / \mathrm{L}$ \\
\hline Alkalinity & GE & $\mathrm{V}$ & 11.7 & & & & & $\mathrm{mg} / \mathrm{L}$ \\
\hline Aluminum & GE & & 443 & & & & 35900 & $\mu g / L$ \\
\hline Americium-241 & GP & $\mathbf{U}$ & 1 & & 6.34 & & & $\mathrm{pCi} / \mathrm{L}$ \\
\hline Ammonia nitrogen & GE & & 0.77 & & & & & $\mathrm{mg} / \mathrm{L}$ \\
\hline Antimony & GE & U & 2 & & 5 & & & $\mu g / L$ \\
\hline Antimony-125 & GP & $\mathbf{U}$ & 20 & & 300 & & & $\mathrm{pCi} / \mathrm{L}$ \\
\hline Arsenic & GE & $\mathbf{U}$ & 2 & & 50 & & 3.2 & $\mu g / L$ \\
\hline Barium & GE & & 140 & & 2000 & & & $\mu g / L$ \\
\hline Beryllium & GE & $\mathbf{U}$ & 3 & & 1 & & & $\mu \mathrm{g} / \mathrm{L}$ \\
\hline Cadmium & GE & $\mathbf{U}$ & 2 & & 5 & & 7.3 & $\mu g / L$ \\
\hline Calcium & GE & & 5720 & & & & & $\mu \mathrm{g} / \mathrm{L}$ \\
\hline Carbon tetrachloride & GE & $\mathrm{U}$ & 1 & & 5 & & & $\mu \mathrm{g} / \mathrm{L}$ \\
\hline Cerium-144 & GP & U & 60 & & 261 & & & $\mathrm{pC} / \mathrm{L}$ \\
\hline Cesium-134 & GP & $\mathbf{U}$ & 10 & & 81.3 & & 0.4 & $\mathrm{pCi} / \mathrm{L}$ \\
\hline Cesium-137 & GP & $\mathbf{U}$ & 10 & & 200 & $\mathrm{U}$ & 0.7 & $\mathrm{pCi} / \mathrm{L}$ \\
\hline Chloride & GE & & 3.86 & & & & 2.4 & $\mathrm{mg} / \mathrm{L}$ \\
\hline Chloroform & GE & $\mathbf{U}$ & 1 & & 100 & & & $\mu \mathrm{g} / \mathrm{L}$ \\
\hline Chromium & GE & $\mathbf{U}$ & 4 & & 100 & & 4.8 & $\mu g / L$ \\
\hline Cobalt-57 & GP & $\mathbf{U}$ & 10 & & 1000 & & & $\mathrm{pCi} / \mathrm{L}$ \\
\hline Cobalt -60 & GP & $\mathbf{U}$ & 10 & & 100 & & 2.2 & $\mathrm{pCi} / \mathrm{L}$ \\
\hline Copper & GE & $\mathbf{U}$ & 4 & & 1300 & $\mathrm{U}$ & 7 & $\mu g / L$ \\
\hline Curium-242 & GP & $\mathbf{U}$ & 1 & & 0.133 & & & $\mathrm{pC} \mathbf{i} / \mathrm{L}$ \\
\hline Curium-243,244 & $\mathbf{G P}$ & $\mathbf{U}$ & 1 & & 8.3 & & & $\mathrm{pCi} / \mathrm{L}$ \\
\hline Europium-152 & GP & $\mathbf{U}$ & 40 & & & & & $\mathrm{pCi} / \mathrm{L}$ \\
\hline Europium-154 & GP & $\mathbf{U}$ & 20 & & 200 & & & $\mathrm{pCi} / \mathrm{L}$ \\
\hline Europium-155 & GP & $\mathbf{U}$ & 30 & & 600 & & & $\mathrm{pCi} / \mathrm{L}$ \\
\hline Fluoride & GE & & 0.228 & & 4 & & & $\mathrm{mg} / \mathrm{L}$ \\
\hline Gross alpha & GE & & 10.2 & 3.8 & 15 & & 89 & $\mathrm{pCi} / \mathrm{L}$ \\
\hline Hardness & GE & & 25 & & & & 187 & $\mathrm{mg} / \mathrm{L}$ \\
\hline Iodine- 129 & $\mathrm{TE}$ & & 41.4 & 5.7 & 1 & $\mathrm{U}$ & 24 & $\mathrm{pCi} / \mathrm{L}$ \\
\hline Iron & $\mathrm{GE}$ & & 698 & & 300 & & & $\mu g / L$ \\
\hline Lead & GE & $\mathbf{U}$ & 3 & & 15 & $\mathbf{U}$ & 3 & $\mu \mathrm{g} / \mathrm{L}$ \\
\hline Magnesium & GE & & 4770 & & & & & $\mu g / L$ \\
\hline Manganese & GE & & 2560 & & 50 & & & $\mu g / L$ \\
\hline Manganese-54 & GP & $\mathbf{U}$ & 10 & & 300 & & & $\mathrm{pCi} / L$ \\
\hline Mercury & GE & & 0.38 & & 2 & $\mathbf{U}$ & 0.2 & $\mu g / L$ \\
\hline Neptunium-237 & $\mathbf{T E}$ & $\mathbf{U}$ & 10 & & 7.06 & $\mathbf{U}$ & 1 & $\mathrm{pCi} / \mathrm{L}$ \\
\hline Nickel & GE & $\mathbf{U}$ & 4 & & 100 & & 50 & $\mu g / L$ \\
\hline Nitrate as nitrogen & GE & & 32.2 & & 10 & & 687 & $\mathrm{mg} / \mathrm{L}$ \\
\hline Nonvolatile beta & GE & & 354.5 & 9.3 & 50 & & 2100 & $\mathrm{pCi} / \mathrm{L}$ \\
\hline Plutonium-238 & GP & $\mathbf{U}$ & 1 & & 7.02 & $\mathbf{U}$ & 1 & $\mathrm{pCi} / \mathrm{L}$ \\
\hline Plutonium-239,240 & GP & $\mathbf{U}$ & 1 & & 62.1 & $\mathbf{U}$ & 1 & $\mathrm{pCi} / \mathrm{L}$ \\
\hline Potassium & $\mathrm{GE}$ & & 1970 & & & & & $\mu g / L$ \\
\hline Potassium -40 & GP & $\mathbf{U}$ & 110 & & 300 & & & $\mathrm{pCi} / \mathrm{L}$ \\
\hline Promethium-144 & GP & $\mathbf{U}$ & 10 & & & & & $\mathrm{pCi} / \mathrm{L}$ \\
\hline
\end{tabular}


(Table 24. Continued)

\begin{tabular}{|c|c|c|c|c|c|c|c|c|}
\hline \multirow[b]{2}{*}{ Analyte } & \multicolumn{5}{|c|}{$7 / 92$} & \multicolumn{3}{|c|}{1989} \\
\hline & Lab & Mod & Result & Ace & Standard & Mod & & Units \\
\hline Promethium-146 & $\mathbf{G P}$ & $\bar{U}$ & 10 & & & & & $\mathrm{pCi} / \mathrm{L}$ \\
\hline Radium-226 & GP & & 1.75 & 0.3 & 15.7 & & 140 & $\mathrm{pCi} / \mathrm{L}$ \\
\hline Radium-228 & GP & & 90.6 & 3.6 & 7.85 & & & $\mathrm{pCi} / \mathrm{L}$ \\
\hline Ruthenium-106 & GP & $\mathbf{U}$ & 90 & & 30 & & & $\mathrm{pCi} / \mathrm{L}$ \\
\hline Selenium & GE & $\mathbf{U}$ & 2 & & 50 & $\mathbf{U}$ & 2 & $\mu g / L$ \\
\hline Silver & GE & $\mathbf{U}$ & 2 & & 50 & $\mathbf{U}$ & 4 & $\mu g / L$ \\
\hline Sodium & GE & & 27000 & & & & 94900 & $\mu \mathrm{g} / \mathrm{L}$ \\
\hline Sodium-22 & GP & $\mathbf{U}$ & 10 & & 466 & & & $\mathrm{pCi} / \mathrm{L}$ \\
\hline Strontium-90 & GP & & 49.2 & 3 & 8 & & 790 & $\mathrm{pCi} / \mathrm{L}$ \\
\hline Technetium-99 & GP & & 2755 & 83 & 900 & & 130 & $\mathrm{pCi} / \mathrm{L}$ \\
\hline Tetrachloroethylene & GE & $\mathrm{U}$ & 1 & & 5 & & & $\mu \mathrm{g} / \mathrm{L}$ \\
\hline Thallium & GE & $\mathbf{U}$ & 2 & & 1 & & & $\mu g / L$ \\
\hline Thorium-228 & GP & $\mathbf{u}$ & 1 & & 125 & & & $\mathrm{pCi} / \mathrm{L}$ \\
\hline Thorium-230 & GP & U & 1 & & 79.2 & & & $\mathrm{pCi} / \mathrm{L}$ \\
\hline Thorium-232 & GP & $\mathbf{U}$ & 1 & & 88 & & & $\mathrm{pCi} / \mathrm{L}$ \\
\hline Tin & GE & U & 2 & & & & & $\mu \mathrm{g} / \mathrm{L}$ \\
\hline Total organic carbon & GE & & 20 & & & & & $\mathrm{mg} / \mathrm{L}$ \\
\hline Total organic halogens & GE & & 18.3 & & & & & $\mu g / L$ \\
\hline Total phenols & GE & $\mathbf{U}$ & 5 & & & & & $\mu \mathrm{g} / \mathrm{L}$ \\
\hline Trichloroethylene & GE & $\mathbf{U}$ & 1 & & 5 & & & $\mu \mathrm{g} / \mathrm{L}$ \\
\hline Tritium & $\mathrm{GE}$ & & 1290 & 5.6 & 20 & & 5900 & $\mathrm{pCi} / \mathrm{ml}$ \\
\hline Uranium-234 & GP & U & 1 & & 13.9 & & & $\mathrm{pCi} / \mathrm{L}$ \\
\hline Uranium-235 & GP & $\mathbf{U}$ & 1 & & 14.5 & & & $\mathrm{pCi} / \mathrm{L}$ \\
\hline Uranium-238 & GP & $\mathbf{U}$ & 1 & & 14.6 & & 2.5 & $\mathrm{pCi} / \mathrm{L}$ \\
\hline Vanadium & $\mathrm{GE}$ & $\mathbf{U}$ & 8 & & & & & $\mu g / L$ \\
\hline Yttrium-88 & GP & $\mathbf{U}$ & 60 & & & & & $\mathrm{pCi} / \mathrm{L}$ \\
\hline Zinc & GE & & 103 & & 5000 & & 107 & $\mu \mathrm{g} / \mathrm{L}$ \\
\hline Zinc-65 & GP & $\mathbf{U}$ & 20 & & 300 & & & $\mathrm{pCi} / \mathrm{L}$ \\
\hline
\end{tabular}


Table 25. FSP290 Laboratory Analyses

Field Measurements:

Sample Date: 07/29/92

pH: 4.83

Specific Conductance: $46 \mu \mathrm{S} / \mathrm{cm}$

\begin{tabular}{|c|c|c|c|c|c|c|}
\hline \multirow{2}{*}{ Analyte } & \multirow[b]{2}{*}{ Lab } & \multicolumn{3}{|c|}{$7 / 92$} & \multirow{2}{*}{ Standard } & \multirow[b]{2}{*}{ Units } \\
\hline & & Mod & Result & $A \propto c$ & & \\
\hline 1,1,1-Trichloroethane & $\mathrm{GE}$ & $\bar{U}$ & 1 & & 200 & $\mu \mathrm{g} / \mathrm{L}$ \\
\hline 1,1,1-Trichloroethane & GE & $\mathbf{U}$ & 1 & & 200 & $\mu g / L$ \\
\hline 1,1,1-trichloroethane & WA & $\mathbf{U}$ & 1 & & 200 & $\mu g / L$ \\
\hline Alkalinity & $\mathrm{GE}$ & & 3.22 & & & $\mathrm{mg} / \mathrm{L}$ \\
\hline Alkalinity & GE & & 2.39 & & & $\mathrm{mg} / \mathrm{L}$ \\
\hline Aluminum & GE & & 635 & & & $\mu g / L$ \\
\hline Aluminum & GE & & 644 & & & $\mu g / L$ \\
\hline Aluminum & WA & $\mathrm{v}$ & 638 & & & $\mu g / L$ \\
\hline Americium-241 & GP & $\mathrm{U}$ & 1 & & 6.34 & $\mathrm{pCi} / \mathrm{L}$ \\
\hline Americium-241 & GP & $\mathbf{U}$ & 1 & & 6.34 & $\mathrm{pCi} / 2$ \\
\hline Americium-241 & $\mathrm{CN}$ & $\mathrm{U}$ & 1 & & 6.34 & $\mathrm{pCi} / \mathrm{L}$ \\
\hline Ammonia nitrogen & GE & $\mathrm{U}$ & 0.1 & & & $\mathrm{mg} / \mathrm{L}$ \\
\hline Ammonia nitrogen & $G E$ & $\mathrm{U}$ & 0.1 & & & $\mathrm{mg} / \mathrm{L}$ \\
\hline Antimony & $\mathrm{GE}$ & $\mathrm{U}$ & 2 & & 5 & $\mu \mathrm{g} / \mathrm{L}$ \\
\hline Antimony & GE & $\mathbf{U}$ & 2 & & 5 & $\mu g / L$ \\
\hline Antimony & WA & U & 2.6 & & 5 & $\mu g / L$ \\
\hline Antimony-125 & GP & $\mathrm{U}$ & 20 & & 300 & $\mathrm{pCi} / \mathrm{L}$ \\
\hline Antimony-125 & GP & U & 20 & & 300 & $\mathrm{pCi} / \mathrm{L}$ \\
\hline Antimony-125 & $\mathrm{CN}$ & $\mathrm{U}$ & 20 & & 300 & $\mathrm{pCi} / \mathrm{L}$ \\
\hline Arsenic & GE & U & $\cdot 2$ & & 50 & $\mu g / L$ \\
\hline Arsenic & $G E$ & U & 2 & & 50 & $\mu g / L$ \\
\hline Arsenic & WA & $\mathrm{U}$ & 2 & & 50 & $\mu g / L$ \\
\hline Barium & GE & & 33.3 & & 2000 & $\mu g / L$ \\
\hline Barium & $\mathrm{GE}$ & & 33.6 & & 2000 & $\mu \mathrm{g} / \mathrm{L}$ \\
\hline Barium & WA & & 33.4 & & 2000 & $\mu \mathrm{g} / \mathrm{L}$ \\
\hline Beryllium & GE & $\mathrm{U}$ & 3 & & 1 & $\mu g / L$ \\
\hline Beryllium & GE & $\mathrm{U}$ & 3 & & 1 & $\mu g / L$ \\
\hline Beryllium & WA & $\mathrm{U}$ & 0.18 & & 1 & $\mu g / L$ \\
\hline Cadmium & GE & $\mathbf{U}$ & 2 & & 5 & $\mu g / L$ \\
\hline Cadmium & GE & $\mathbf{U}$ & 2 & & 5 & $\mu g / L$ \\
\hline Cadmium & WA & $\mathrm{U}$ & 0.35 & & 5 & $\mu g / L$ \\
\hline Calcium & GE & & 645 & & & $\mu g / L$ \\
\hline Calcium & GE & & 577 & & & $\mu \mathrm{g} / \mathrm{L}$ \\
\hline Calcium & WA & & 654 & & & $\mu g / L$ \\
\hline Carbon tetrachloride & $\mathrm{GE}$ & $\mathrm{U}$ & 1 & & 5 & $\mu g / L$ \\
\hline Carbon tetrachloride & $\mathrm{GE}$ & $\mathrm{U}$ & 1 & & 5 & $\mu g / L$ \\
\hline Carbon tetrachloride & WA & $\mathrm{U}$ & 1 & & 5 & $\mu g / L$ \\
\hline Cerium-144 & GP & $\mathrm{U}$ & 60 & & 261 & $\mathrm{pCi} / \mathrm{L}$ \\
\hline Cerium-144 & GP & $\mathrm{U}$ & 60 & & 261 & $\mathrm{pCi} / \mathrm{L}$ \\
\hline Cerium-144 & $\mathrm{CN}$ & $\mathrm{U}$ & 50 & & 261 & $\mathrm{pCi} / \mathrm{L}$ \\
\hline Cesium-134 & GP & $\mathrm{U}$ & 10 & & 81.3 & $\mathrm{pCi} / \mathrm{L}$ \\
\hline Cesium-134 & GP & $\mathrm{U}$ & 10 & & 81.3 & $\mathrm{pCi} / \mathrm{L}$ \\
\hline Cesium-134 & $\mathrm{CN}$ & $\mathrm{U}$ & 10 & & 81.3 & $\mathrm{pCi} / \mathrm{L}$ \\
\hline Cesium-137 & GP & $\mathrm{U}$ & 10 & & 200 & $\mathrm{pCi} / \mathrm{L}$ \\
\hline Cesium-137 & GP & U & 10 & & 200 & $\mathrm{pCi} / \mathrm{L}$ \\
\hline Cesium-137 & $\mathrm{CN}$ & $\mathrm{U}$ & 10 & & 200 & $\mathrm{pCi} / \mathrm{L}$ \\
\hline
\end{tabular}


(Table 25. Continued)

\begin{tabular}{|c|c|c|c|c|c|c|}
\hline Analyte & Lab & Mod & $\begin{array}{c}7 / 92 \\
\text { Result }\end{array}$ & $A \propto$ & Standard & Units \\
\hline Chloride & $\mathrm{GE}$ & & 3.85 & & & $\mathrm{mg} / \mathrm{L}$ \\
\hline Chloride & $G E$ & & 4.06 & & & $\mathrm{mg} / \mathrm{L}$ \\
\hline Chloride & WA & & 5.12 & & & $\mathrm{mg} / \mathrm{L}$ \\
\hline Chloroform & $\mathrm{GE}$ & $\mathrm{U}$ & 1 & & 100 & $\mu g / L$ \\
\hline Chloroform & $\mathrm{GE}$ & $\mathbf{U}$ & 1 & & 100 & $\mu g / L$ \\
\hline Chloroform & WA & $\mathbf{U}$ & 1 & & 100 & $\mu g / L$ \\
\hline Chromium & $\mathrm{GE}$ & U. & 4 & & 100 & $\mu \mathrm{g} / \mathrm{L}$ \\
\hline Chromium & $\mathrm{GE}$ & $\mathrm{U}$ & 4 & & 100 & $\mu \mathrm{g} / \mathrm{L}$ \\
\hline Chromium & WA & UV & 1.1 & & 100 & $\mu g / L$ \\
\hline Cobalt-57 & GP & $\mathbf{U}$ & 10 & & 1000 & $\mathrm{pC} / / 2$ \\
\hline Cobalt-57 & GP & $\mathrm{U}$ & 10 & & 1000 & $\mathrm{pCi} / \mathrm{L}$ \\
\hline Cobalt-57 & $\mathrm{CN}$ & $\mathbf{U}$ & 10 & & 1000 & $\mathrm{pCi} / \mathrm{L}$ \\
\hline Cobalt- 60 & GP & $\mathrm{U}$ & 10 & & 100 & $\mathrm{pCi} / \mathrm{L}$ \\
\hline Cobalt- 60 & GP & $\mathrm{U}$ & 10 & & 100 & $\mathrm{pCi} / \mathrm{L}$ \\
\hline Cobalt-60 & $\mathrm{CN}$ & $\mathbf{U}$ & 10 & & 100 & $\mathrm{pCi} / \mathrm{L}$ \\
\hline Copper & $\mathrm{GE}$ & $\mathrm{U}$ & 4 & & 1300 & $\mu g / L$ \\
\hline Copper & $G E$ & $\mathrm{U}$ & 4 & & 1300 & $\mu g / L$ \\
\hline Copper & WA & $\mathrm{U}$ & 1.1 & & 1300 & $\mu g / L$ \\
\hline Curium-242 & GP & $\mathrm{U}$ & 1 & & 0.133 & $\mathrm{pCi} / \mathrm{L}$ \\
\hline Curium-242 & GP & $\mathrm{U}$ & 1 & & 0.133 & $\mathrm{pCi} / \mathrm{L}$ \\
\hline Curium-242 & $\mathrm{CN}$ & $\mathrm{U}$ & 1 & & 0.133 & $\mathrm{pCi} / \mathrm{L}$ \\
\hline Curium-243,244 & GP & $\mathrm{U}$ & 1 & & 8.3 & $\mathrm{pCi} / \mathrm{L}$ \\
\hline Curium-243,244 & GP & $\mathrm{U}$ & 1 & & 8.3 & $\mathrm{pCi} / \mathrm{L}$ \\
\hline Curium-243,244 & $\mathrm{CN}$ & $\mathrm{U}$ & 1 & & 8.3 & $\mathrm{pCi} / \mathrm{L}$ \\
\hline Europium-152 & GP & $\mathrm{U}$ & 40 & & & $\mathrm{pCi} / \mathrm{L}$ \\
\hline Europium-152 & GP & $\mathrm{U}$ & 40 & & & $\mathrm{pCi} / \mathrm{L}$ \\
\hline Europium-152 & $\mathrm{CN}$ & $\mathrm{U}$ & 40 & & & $\mathrm{pCi} / \mathrm{L}$ \\
\hline Europium-154 & $\mathrm{CN}$ & $\mathrm{U}$ & 25 & & 200 & $\mathrm{pCi} / \mathrm{L}$ \\
\hline Europium-154 & GP & U & 20 & & 200 & $\mathrm{pCi} / \mathrm{L}$ \\
\hline Europium-154 & GP & $\mathrm{U}$ & 20 & & 200 & $\mathrm{pCi} / \mathrm{L}$ \\
\hline Europium-155 & GP & $\mathrm{U}$ & 30 & & 600 & $\mathrm{pCi} / L$ \\
\hline Europium-155 & GP & $\mathrm{U}$ & 30 & & 600 & $\mathrm{pCi} / \mathrm{L}$ \\
\hline Europium-155 & $\mathrm{CN}$ & $\mathrm{U}$ & 25 & & 600 & $\mathrm{pCi} / \mathrm{L}$ \\
\hline Fluoride & GE & $\mathrm{U}$ & 0.1 & & 4 & $\mathrm{mg} / \mathrm{L}$ \\
\hline Fluoride & GE & $\mathrm{U}$ & 0.1 & & 4 & $\mathrm{mg} / \mathrm{L}$ \\
\hline Fluoride & WA & $\mathrm{U}$ & 0.1 & & 4 & $\mathrm{mg} / \mathrm{L}$ \\
\hline Gross aipha & GE & $\mathrm{U}$ & 2 & & 15 & $\mathrm{pCi} / \mathrm{L}$ \\
\hline Gross alpha & $\mathrm{GE}$ & $\mathrm{U}$ & 2 & & 15 & $\mathrm{pCi} / \mathrm{L}$ \\
\hline Gross-alpha & TM & & 0.9 & 0.9 & & $\mathrm{pCi} / \mathrm{L}$ \\
\hline Hardness & $\mathrm{GE}$ & & 3.62 & & & $\mathrm{mg} / \mathrm{L}$ \\
\hline Hardness & $\mathrm{GE}$ & & 12.5 & & & $\mathrm{mg} / \mathrm{L}$ \\
\hline Iodine-129 & $\mathrm{TE}$ & $\mathbf{U}$ & 2 & & 1 & $\mathrm{pCi} / \mathrm{L}$ \\
\hline Iodine-129 & $\mathrm{TE}$ & $\mathbf{U}$ & 2 & & 1 & $\mathrm{pCi} / \mathrm{L}$ \\
\hline Iodine-129 & $\mathrm{CN}$ & $\mathbf{U}$ & 2 & & 1 & pCi/L \\
\hline Iron & $\mathrm{GE}$ & $\mathrm{J} 2$ & 3440 & & 300 & $\mu g / L$ \\
\hline Iron & $\mathrm{GE}$ & $\mathrm{J} 2$ & 3240 & & 300 & $\mu g / L$ \\
\hline Iron & WA & $\mathrm{V}$ & 3810 & & 300 & $\mu g / L$ \\
\hline Lead & $\mathrm{GE}$ & & 4.74 & & 15 & $\mu g / L$ \\
\hline Lead & $\mathrm{GE}$ & & 6.15 & & 15 & $\mu g / L$ \\
\hline
\end{tabular}


(Table 25. Continued)

\begin{tabular}{|c|c|c|c|c|c|c|}
\hline \multirow[b]{2}{*}{ Analyte } & \multicolumn{4}{|c|}{$7 / 92$} & \multirow[b]{2}{*}{ Standard } & \multirow[b]{2}{*}{ Units } \\
\hline & Lab & Mod & Result & Acc & & \\
\hline Lead & WA & $\mathrm{J} 3 \mathrm{~V}$ & 5.8 & & 15 & $\mu \mathrm{g} / \mathrm{L}$ \\
\hline Magnesium & GE & & 487 & & & $\mu g / L$ \\
\hline Magnesium & GE & & 483 & & & $\mu g / L$ \\
\hline Magnesium & WA & & 486 & & & $\mu g / L$ \\
\hline Manganese & $G E$ & & 50.6 & & 50 & $\mu g / L$ \\
\hline Manganese & GE & & 48.7 & & 50 & $\mu g / L$ \\
\hline Manganese & WA & & 54.4 & & 50 & $\mu g / L$ \\
\hline Manganese-54 & GP & $\mathbf{U}$ & 10 & & 300 & $\mathrm{pCi} / \mathrm{L}$ \\
\hline Manganese-54 & GP & $\mathbf{U}$ & 10 & & 300 & $\mathrm{pCi} / \mathrm{L}$ \\
\hline Manganese-54 & $\mathrm{CN}$ & $\mathbf{U}$ & 10 & & 300 & $\mathrm{pCi} / \mathrm{L}$ \\
\hline Mercury & GE & $\mathbf{U}$ & 0.2 & & 2 & $\mu g / L$ \\
\hline Mercury & GE & & 0.51 & & 2 & $\mu g / L$ \\
\hline Mercury & WA & $\mathbf{U}$ & 0.2 & & 2 & $\mu g / L$ \\
\hline Neptunium-237 & TE & U & 10 & & 7.06 & $\mathrm{pCi} / \mathrm{L}$ \\
\hline Neptunium-237 & TE & $\mathbf{U}$ & 10 & & 7.06 & $\mathrm{pCi} / \mathrm{L}$ \\
\hline Neptunium-237 & $\mathrm{CN}$ & $\mathbf{U}$ & 45 & & 7.06 & $\mathrm{pCi} / \mathrm{L}$ \\
\hline Neptunium-237 & $\mathrm{CN}$ & $\mathbf{U}$ & 1 & & 7.06 & $\mathrm{pCi} / \mathrm{L}$ \\
\hline Nickel & GE & $\mathbf{U}$ & 4 & & 100 & $\mu g / L$ \\
\hline Nickel & GE & U & 4 & & 100 & $\mu g / L$ \\
\hline Nickel & WA & $\mathrm{J} 3$ & 5.3 & & 100 & $\mu g / L$ \\
\hline Nitrate as nitrogen & WA & & 0.56 & & 10 & $\mathrm{mg} / \mathrm{L}$ \\
\hline Nitrate as nitrogen & GE & & 0.37 & & 10 & $\mathrm{mg} / \mathrm{L}$ \\
\hline Nitrate as nitrogen & GE & & 0.17 & & 10 & $\mathrm{mg} / \mathrm{L}$ \\
\hline Nonvolatile beta & GE & & 2.3 & 1.4 & 50 & $\mathrm{pCi} / \mathrm{L}$ \\
\hline Nonvolatile beta & GE & $\mathbf{U}$ & 2 & & 50 & $\mathrm{pCi} / \mathrm{L}$ \\
\hline Nonvolatile beta & TM & $\mathbf{U}$ & 0.7 & & 50 & $\mathrm{pCi} / \mathrm{L}$ \\
\hline Plutonium-238 & GP & $\mathbf{U}$ & 1 & & 7.02 & $\mathrm{pCi} / \mathrm{L}$ \\
\hline Plutonium-238 & GP & $\mathbf{U}$ & 1 & & 7.02 & $\mathrm{pCi} / \mathrm{L}$ \\
\hline Plutonium-238 & $\mathrm{CN}$ & $\mathbf{U}$ & 1 & & 7.02 & $\mathrm{pCi} / \mathrm{L}$ \\
\hline Plutonium-239,240 & GP & $\mathbf{U}$ & 1 & & 62.1 & $\mathrm{pCi} / \mathrm{L}$ \\
\hline Plutonium-239,240 & GP & $\mathrm{U}$ & 1 & & 62.1 & $\mathrm{pCi} / \mathrm{L}$ \\
\hline Plutonium-239,240 & $\mathrm{CN}$ & $\mathrm{U}$ & 1 & & 62.1 & $\mathrm{pCi} / \mathrm{L}$ \\
\hline Potassium & GE & & 1110 & & & $\mu g / L$ \\
\hline Potassium & $\mathrm{GE}$ & & 1070 & & & $\mu g / L$ \\
\hline Potassium & WA & V & 1130 & & & $\mu g / L$ \\
\hline Potassium-40 & GP & $\mathbf{U}$ & 110 & & 300 & $\mathrm{pCi} / \mathrm{L}$ \\
\hline Potassium-40 & GP & $\mathbf{U}$ & 110 & & 300 & $\mathrm{pCi} / \mathrm{L}$ \\
\hline Potassium -40 & $\mathrm{CN}$ & $\mathbf{U}$ & 175 & & 300 & $\mathrm{pCi} / \mathrm{L}$ \\
\hline Promethium-144 & GP & $\mathbf{U}$ & 10 & & & $\mathrm{pCi} / \mathrm{L}$ \\
\hline Promethium-144 & GP & $\mathbf{U}$ & 10 & & & $\mathrm{pCi} / \mathrm{L}$ \\
\hline Promethium-144 & $\mathrm{CN}$ & $\mathbf{U}$ & 10 & & & pCi/L \\
\hline Promethium-146 & GP & $\mathbf{U}$ & 10 & & & $\mathrm{pCi} / \mathrm{L}$ \\
\hline Promethium-146 & GP & $\mathbf{U}$ & 10 & & & $\mathrm{pCi} / \mathrm{L}$ \\
\hline Promethium-146 & $\mathrm{CN}$ & $\mathbf{U}$ & 20 & & & $\mathrm{pCi} / \mathrm{L}$ \\
\hline Radium-226 & GP & $\mathbf{U}$ & 1 & & 15.7 & $\mathrm{pCi} / \mathrm{L}$ \\
\hline Radium-226 & GP & $\mathbf{U}$ & 1 & & 15.7 & $\mathrm{pCi} / \mathrm{L}$ \\
\hline Radium-226 & CN & $\mathbf{U}$ & 175 & & 15.7 & $\mathrm{pCi} / \mathrm{L}$ \\
\hline Radium-228 & GP & & 1.93 & 1.4 & 7.85 & $\mathrm{pCi} / \mathrm{L}$ \\
\hline Radium-228 & GP & & 1.83 & 0.84 & 7.85 & $\mathrm{pCi} / \mathrm{L}$ \\
\hline
\end{tabular}


(Table 25. Continued)

\begin{tabular}{|c|c|c|c|c|c|c|}
\hline Analyte & Lab & Mod & $\begin{array}{c}7 / 92 \\
\text { Result }\end{array}$ & $A \propto c$ & Standard & Units \\
\hline Radium226 & $\mathrm{CN}$ & $\mathbf{U}$ & 1 & & & $\mathrm{pCi} / \mathrm{L}$ \\
\hline Radium228 & $\mathrm{CN}$ & & 12.1 & 0.9 & & pCi/L \\
\hline Ruthenium-106 & GP & $\mathbf{U}$ & 90 & & 30 & $\mathrm{pCi} / \mathrm{L}$ \\
\hline Ruthenium-106 & GP & U & 90 & & 30 & $\mathrm{pCi} / \mathrm{L}$ \\
\hline Ruthenium-106 & $\mathrm{CN}$ & $\mathbf{U}$ & 70 & & & pCi/L \\
\hline Selenium & GE & UJ1 & 2 & & 50 & $\mu g / L$ \\
\hline Selenium & GE & UJ1 & 2 & & 50 & $\mu g / L$ \\
\hline Selenium & WA & $\mathbf{U}$ & 2 & & 50 & $\mu \mathrm{g} / \mathrm{L}$ \\
\hline Silver & GE & U & 2 & & 50 & $\mu g / L$ \\
\hline Silver & GE & U & 2 & & 50 & $\mu g / L$ \\
\hline Silver & WA & $\mathbf{U}$ & 0.7 & & 50 & $\mu \mathrm{g} / \mathrm{L}$ \\
\hline Sodium & GE & & 2660 & & & $\mu \mathrm{g} / \mathrm{L}$ \\
\hline Sodium & GE & & 2680 & & & $\mu g / L$ \\
\hline Sodium & WA & & 2780 & & & $\mu g / L$ \\
\hline Sodium-22 & GP & U & 10 & & 466 & $\mathrm{pCi} / \mathrm{L}$ \\
\hline Sodium-22 & GP & $\mathrm{U}$ & 10 & & 466 & $\mathrm{pCi} / \mathrm{L}$ \\
\hline Sodium-22 & $\mathrm{CN}$ & $\mathrm{U}$ & 10 & & 466 & $\mathrm{pCi} / \mathrm{L}$ \\
\hline Strontium-90 & GP & $\mathbf{U}$ & 2 & & 8 & $\mathrm{pCi} / \mathrm{L}$ \\
\hline Strontium-90 & GP & $\mathrm{U}$ & 2 & & 8 & $\mathrm{pCi} / \mathrm{L}$ \\
\hline Strontium-90 & $\mathrm{CN}$ & $\mathrm{U}$ & 2 & & 8 & $\mathrm{pCi} / \mathrm{L}$ \\
\hline Technetium-99 & GP & $\mathbf{U}$ & 300 & & 900 & $\mathrm{pCi} / \mathrm{L}$ \\
\hline Technetium-99 & GP & $\mathbf{U}$ & 300 & & 900 & $\mathrm{pCi} / \mathrm{L}$ \\
\hline Technetium-99 & $\mathrm{CN}$ & $\mathbf{U}$ & 300 & & 900 & $\mathrm{pCi} / \mathrm{L}$ \\
\hline Tetrachloroethylene & GE & $\mathbf{U}$ & 1 & & 5 & $\mu \mathrm{g} / \mathrm{L}$ \\
\hline Tetrachloroethylene & GE & $\mathbf{U}$ & 1 & & 5 & $\mu g / L$ \\
\hline Tetrachloroethylene & WA & $\mathbf{U}$ & 1 & & 5 & $\mu g / L$ \\
\hline Thallium & GE & $\mathbf{U}$ & 2 & & 1 & $\mu g / L$ \\
\hline Thallium & GE & $\mathbf{U}$ & 2 & & 1 & $\mu g / L$ \\
\hline Thallium & WA & $\mathbf{U}$ & 2 & & 1 & $\mu g / L$ \\
\hline Thorium-228 & GP & $\mathrm{U}$ & 1 & & 125 & $\mathrm{pCi} / \mathrm{L}$ \\
\hline Thorium-228 & GP & $\mathrm{U}$ & 1 & & 125 & $\mathrm{pCi} / \mathrm{L}$ \\
\hline Thorium-228 & $\mathrm{CN}$ & U & 400 & & 125 & $\mathrm{pCi} / \mathrm{L}$ \\
\hline Thorium-228 & $\mathrm{CN}$ & U & 1 & & 125 & $\mathrm{pCi} / \mathrm{L}$ \\
\hline Thorium-230 & GP & $\mathrm{U}$ & 1 & & 79.2 & $\mathrm{pCi} / \mathrm{L}$ \\
\hline Thorium-230 & GP & & 1.32 & 0.28 & 79.2 & $\mathrm{pCi} / \mathrm{L}$ \\
\hline Thorium-230 & $\mathrm{CN}$ & $\mathbf{U}$ & 1 & & 79.2 & $\mathrm{pCi} / \mathrm{L}$ \\
\hline Thorium-232 & GP & $\mathbf{U}$ & 1 & & 88 & $\mathrm{pCi} / \mathrm{L}$ \\
\hline Thorium-232 & GP & $\mathrm{U}$ & 1 & & 88 & $\mathrm{pCi} / \mathrm{L}$ \\
\hline Thorium-232 & $\mathrm{CN}$ & $\mathrm{U}$ & 1 & & 88 & $\mathrm{pCi} / \mathrm{L}$ \\
\hline Tin & GE & & 2.48 & & & $\mu g / L$ \\
\hline Tin & $\mathrm{GE}$ & $U$ & 2 & & & $\mu g / L$ \\
\hline Tin & WA & $\mathbf{V}$ & 13.2 & & & $\mu g / L$ \\
\hline Total organic carbon & GE & & 21 & & & $\mathrm{mg} / \mathrm{L}$ \\
\hline Total organic carbon & GE & & 24 & & & $\mathrm{mg} / \mathrm{L}$ \\
\hline Total organic carbon & WA & & 40.1 & & & $\mathrm{mg} / \mathrm{L}$ \\
\hline Total organic halogens & GE & & 59.65 & & & $\mu g / L$ \\
\hline Total organic halogens & GE & & 43.1 & & & $\mu \mathrm{g} / \mathrm{L}$ \\
\hline Total organic halogens & WA & & 65.8 & & & $\mu \mathrm{g} / \mathrm{L}$ \\
\hline Total phenols & GE & $\mathrm{U}$ & 5 & & & $\mu g / L$ \\
\hline
\end{tabular}


(Table 25. Continued)

\begin{tabular}{|c|c|c|c|c|c|c|}
\hline Analyte & Lab & Mod & $\begin{array}{c}7 / 92 \\
\text { Result }\end{array}$ & $A \propto$ & Standard & Units \\
\hline Total phenols & GE & $\bar{U}$ & 5 & & & $\mu g / L$ \\
\hline Total phenols & WA & $\mathbf{U}$ & 5 & & & $\mu g / L$ \\
\hline Trichloroethylene & GE & $\mathbf{U}$ & 1 & & 5 & $\mu g / L$ \\
\hline Trichloroethylene & GE & $\mathbf{U}$ & 1 & & 5 & $\mu g / L$ \\
\hline Trichloroethylene & WA & $\mathbf{U}$ & 1 & & 5 & $\mu g / L$ \\
\hline Tritium & GE & & 60.1 & 1.35 & 20 & $\mathrm{pCi} / \mathrm{ml}$ \\
\hline Tritium & GE & & 56.8 & 1.3 & 20 & $\mathrm{pCi} / \mathrm{ml}$ \\
\hline Tritium & TM & & 66 & 7.3 & 20 & $\mathrm{pCi} / \mathrm{L}$ \\
\hline Uranium-234 & GP & $\mathbf{U}$ & 1 & & 13.9 & $\mathrm{pCi} / \mathrm{L}$ \\
\hline Uranium-234 & GP & $\mathbf{U}$ & 1 & & 13.9 & $\mathrm{pCi} / \mathrm{L}$ \\
\hline Uranium-234 & $\mathrm{CN}$ & U & 1 & & 13.9 & $\mathrm{pCi} / \mathrm{L}$ \\
\hline Uranium-235 & GP & U & 1 & & 14.5 & $\mathrm{pCi} / \mathrm{L}$ \\
\hline Uranium-235 & GP & $\mathbf{U}$ & 1 & & 14.5 & $\mathrm{pCi} / \mathrm{L}$ \\
\hline Uranium-235 & $\mathrm{CN}$ & U & 15 & & 14.5 & $\mathrm{pCi} / \mathrm{L}$ \\
\hline Uranium-235 & $\mathrm{CN}$ & U & 1 & & 14.5 & $\mathrm{pCi} / \mathrm{L}$ \\
\hline Uranium-238 & GP & U & 1 & & 14.6 & $\mathrm{pCi} / \mathrm{L}$ \\
\hline Uranium-238 & GP & U & 1 & & 14.6 & $\mathrm{pCi} / \mathrm{L}$ \\
\hline Uranium-238 & $\mathrm{CN}$ & U & 1 & & 14.6 & $\mathrm{pCi} / \mathrm{L}$ \\
\hline Vanadium & GE & U & 8 & & & $\mu g / L$ \\
\hline Vanadium & GE & U & 8 & & & $\mu \mathrm{g} / \mathrm{L}$ \\
\hline Vanadium & WA & $U$ & 0.88 & & & $\mu g / L$ \\
\hline Ytrium-88 & GP & $\mathrm{U}$ & 60 & & & $\mathrm{pCi} / \mathrm{L}$ \\
\hline Yttrium-88 & GP & U & 60 & & & $\mathrm{pCi} / \mathrm{L}$ \\
\hline Yttrium-88 & $\mathrm{CN}$ & U & 10 & & & $\mathrm{pCi} / \mathrm{L}$ \\
\hline Zinc & GE & & 91 & & 5000 & $\mu g / L$ \\
\hline Zinc & GE & & 90.8 & & 5000 & $\mu \mathrm{g} / \mathrm{L}$ \\
\hline Zinc & WA & & 92.9 & & 5000 & $\mu g / L$ \\
\hline Zinc-65 & GP & $\mathrm{U}$ & 20 & & 300 & $\mathrm{pCi} / \mathrm{L}$ \\
\hline Zinc-65 & GP & U & 20 & & 300 & $\mathrm{pCi} / \mathrm{L}$ \\
\hline Zinc-65 & $\mathrm{CN}$ & U & 20 & & 300 & $\mathrm{pC} \mathrm{i} / \mathrm{L}$ \\
\hline
\end{tabular}


Table 26. HSP008 Laboratory Analyses

Field Measurements:

Sample Date: 07/23/92

pH: 6.32

Specific Conductance: $237 \mu \mathrm{S} / \mathrm{cm}$

\begin{tabular}{|c|c|c|c|c|c|c|}
\hline Analyte & Lab & Mod & $\begin{array}{c}7 / 92 \\
\text { Result }\end{array}$ & $A \propto C$ & Standard & Units \\
\hline 1,1,1-Trichloroethane & $\mathrm{GE}$ & $\mathrm{U}$ & 1 & & 200 & $\mu g / L$ \\
\hline 1,1,1-Trichloroethane & GE & $\mathbf{U}$ & 1 & & 200 & $\mu \mathrm{g} / \mathrm{L}$ \\
\hline 1,1,1-Trichloroethane & WA & $\mathrm{U}$ & 1 & & 200 & $\mu g / L$ \\
\hline Alkalinity & GE & $\mathbf{U}$ & 1 & & & $\mathrm{mg} / \mathrm{L}$ \\
\hline Alkalinity & GE & & 66.9 & & & $\mathrm{mg} / \mathrm{L}$ \\
\hline Aluminum & $G E$ & & 8930 & & & $\mu \mathrm{g} / \mathrm{L}$ \\
\hline Aluminum & $\mathrm{GE}$ & & 14100 & & & $\mu g / L$ \\
\hline Aluminum & WA & $\mathrm{v}$ & 23000 & & & $\mu \mathrm{g} / \mathrm{L}$ \\
\hline Americium-241 & GP & $\mathrm{U}$ & 1 & & 6.34 & $\mathrm{pCi} / \mathrm{L}$ \\
\hline Americium-241 & GP & $\mathrm{U}$ & 1 & & 6.34 & $\mathrm{pCi} / \mathrm{L}$ \\
\hline Americium-24I & $\mathrm{CN}$ & $\mathrm{U}$ & 1 & & 6.34 & $\mathrm{pCi} / \mathrm{L}$ \\
\hline Ammonia nitrogen & GE & $\mathrm{U}$ & 0.1 & & & $\mathrm{mg} / \mathrm{L}$ \\
\hline Ammonia nitrogen & $G E$ & $\mathrm{U}$ & 0.1 & & & $\mathrm{mg} / \mathrm{L}$ \\
\hline Antimony & GE & $\mathrm{U}$ & 2 & & 5 & $\mu g / L$ \\
\hline Antimony & GE & $\mathbf{U}$ & 2 & & 5 & $\mu g / L$ \\
\hline Antimony & WA & $\mathbf{U}$ & 2.6 & & 5 & $\mu g / L$ \\
\hline Antimony-125 & GP & $\mathbf{U}$ & 20 & & 300 & $\mathrm{pCi} / \mathrm{L}$ \\
\hline Antimony-125 & GP & $\mathbf{U}$ & 20 & & 300 & $\mathrm{pC} / \Omega$ \\
\hline Antimony-125 & $\mathrm{CN}$ & $\mathrm{U}$ & 20 & & 300 & $\mathrm{pCi} / \mathrm{L}$ \\
\hline Arsenic & GE & $\mathrm{U}$ & 2 & & 50 & $\mu g / L$ \\
\hline Arsenic & GE & $\mathrm{U}$ & 2 & & 50 & $\mu g / L$ \\
\hline Arsenic & WA & $\mathbf{U}$ & 2 & & 50 & $\mu \mathrm{g} / \mathrm{L}$ \\
\hline Barium & $\mathrm{GE}$ & & 28.5 & & 2000 & $\mu g / L$ \\
\hline Barium & GE & & 32.1 & & 2000 & $\mu g / L$ \\
\hline Barium & WA & & 82.5 & & 2000 & $\mu \mathrm{g} / \mathrm{L}$ \\
\hline Beryllium & $\mathrm{GE}$ & $U$ & 3 & & 1 & $\mu \mathrm{g} / \mathrm{L}$ \\
\hline Beryllium & GE & $\mathrm{U}$ & 3 & & 1 & $\mu g / L$ \\
\hline Beryllium & WA & $\mathrm{J} 3$ & 0.6 & & 1 & $\mu \mathrm{g} / \mathrm{L}$ \\
\hline Cadmium & GE & $\mathbf{U}$ & 2 & & 5 & $\mu g / L$ \\
\hline Cadmium & $\mathrm{GE}$ & $\mathrm{U}$ & 2 & & 5 & $\mu \mathrm{g} / \mathrm{L}$ \\
\hline Cadmium & WA & $\mathrm{U}$ & 0.35 & & 5 & $\mu \mathrm{g} / \mathrm{L}$ \\
\hline Calcium & $\mathrm{GE}$ & $\mathrm{J} 2$ & 1430 & & & $\mu g / L$ \\
\hline Calcium & $\mathrm{GE}$ & $\mathrm{J} 2$ & 2230 & & & $\mu \mathrm{g} / \mathrm{L}$ \\
\hline Calcium & WA & & 1560 & & & $\mu g / L$ \\
\hline Carbon tetrachloride & $\mathrm{GE}$ & U & 1 & & 5 & $\mu g / L$ \\
\hline Carbon tetrachloride & $\mathrm{GE}$ & $\mathbf{U}$ & 1 & & 5 & $\mu g / L$ \\
\hline Carbon tetrachloride & WA & $\mathrm{U}$ & 1 & & 5 & $\mu g / L$ \\
\hline Cerium-144 & GP & $\mathbf{U}$ & 60 & & 261 & $\mathrm{pC} / / \mathrm{L}$ \\
\hline Cerium-144 & GP & $\mathbf{U}$ & 60 & & 261 & $\mathrm{pCi} / \mathrm{L}$ \\
\hline Cerium-144 & $\mathrm{CN}$ & $\mathbf{U}$ & 50 & & 261 & $\mathrm{pC} / \mathrm{L}$ \\
\hline Cesium-134 & GP & U & 10 & & 81.3 & $\mathrm{pCi} / /$ \\
\hline Cesium-134 & GP & $\mathbf{U}$ & 10 & & 81.3 & $\mathrm{pCi} / \mathrm{L}$ \\
\hline Cesium-134 & $\mathrm{CN}$ & $\mathrm{U}$ & 10 & & 81.3 & $\mathrm{pCi} / \mathrm{L}$ \\
\hline Cesium-137 & GP & $\mathbf{U}$ & 10 & & 200 & $\mathrm{pCi} / \mathrm{L}$ \\
\hline Cesium-137 & GP & $\mathrm{U}$ & 10 & & 200 & $\mathrm{pCi} / \mathrm{L}$ \\
\hline Cesium-137 & $\mathrm{CN}$ & $U$ & 10 & & 200 & $\mathrm{pCi} / \mathrm{L}$ \\
\hline
\end{tabular}


(Table 26. Continued)

\begin{tabular}{|c|c|c|c|c|c|c|}
\hline Analyte & Lab & Mod & $\begin{array}{c}7 / 92 \\
\text { Result }\end{array}$ & $A \propto$ & Standard & Units \\
\hline Chloride & $\mathrm{GE}$ & & 3.47 & & & $\mathrm{mg} / \mathrm{L}$ \\
\hline Chloride & $\mathrm{GE}$ & & 3.24 & & & $\mathrm{mg} / \mathrm{L}$ \\
\hline Chloride & WA & & 4.14 & & & $\mathrm{mg} / \mathrm{L}$ \\
\hline Chloroform & $\mathrm{GE}$ & $\mathbf{U}$ & 1 & & 100 & $\mu g / L$ \\
\hline Chloroform & $\mathrm{GE}$ & $\mathbf{U}$ & 1 & & 100 & $\mu g / L$ \\
\hline Chloroform & WA & U & 1 & & 100 & $\mu g / L$ \\
\hline Chromium & GE & & 5.78 & & 100 & $\mu g / L$ \\
\hline Chromium & $\mathrm{GE}$ & & 8.68 & & 100 & $\mu g / L$ \\
\hline Chromium & WA & & 25.1 & & 100 & $\mu g / L$ \\
\hline Cobalt-57 & GP & U & 10 & & 1000 & $\mathrm{pCi} / \mathrm{L}$ \\
\hline Cobalt-57 & GP & U & 10 & & 1000 & $\mathrm{pCi} / \mathrm{L}$ \\
\hline Cobalt-57 & $\mathrm{CN}$ & $\mathbf{U}$ & 10 & & 1000 & $\mathrm{pCi} / \mathrm{L}$ \\
\hline Cobalt-60 & GP & $\mathrm{U}$ & 10 & & 100 & $\mathrm{pCi} / \mathrm{L}$ \\
\hline Cobalt-60 & GP & $\mathrm{U}$ & 10 & & 100 & $\mathrm{pCi} / \mathrm{L}$ \\
\hline Cobalt-60 & $\mathrm{CN}$ & $\mathrm{U}$ & 10 & & 100 & $\mathrm{pCi} / \mathrm{L}$ \\
\hline Copper & $G E$ & & 4.33 & & 1300 & $\mu g / L$ \\
\hline Copper & $\mathrm{GE}$ & & 5.19 & & 1300 & $\mu g / L$ \\
\hline Copper & WA & J3 & 3.5 & & 1300 & $\mu g / L$ \\
\hline Curium-242 & GP & $\mathbf{U}$ & 1 & & 0.133 & $\mathrm{pCi} / \mathrm{L}$ \\
\hline Curium-242 & GP & $\mathbf{U}$ & 1 & & 0.133 & $\mathrm{pCi} / \mathrm{L}$ \\
\hline Curium-242 & $\mathrm{CN}$ & $\mathbf{U}$ & 1 & & 0.133 & $\mathrm{pCi} / \mathrm{L}$ \\
\hline Curium-243,244 & GP & $\mathrm{U}$ & 1 & & 8.3 & $\mathrm{pCi} / \mathrm{L}$ \\
\hline Curium-243,244 & GP & $\mathrm{U}$ & 1 & & 8.3 & $\mathrm{pCi} / \mathrm{L}$ \\
\hline Curium-243,244 & $\mathrm{CN}$ & $\mathbf{U}$ & 1 & & 8.3 & $\mathrm{pCi} / \mathrm{L}$ \\
\hline Europium-152 & GP & $\mathbf{U}$ & 40 & & & $\mathrm{pCi} / \mathrm{L}$ \\
\hline Europium-152 & GP & $\mathrm{U}$ & 40 & & & $\mathrm{pCi} / \mathrm{L}$ \\
\hline Europium-152 & $\mathrm{CN}$ & $\mathbf{U}$ & 40 & & & $\mathrm{pCi} / \mathrm{L}$ \\
\hline Europium-154 & GP & $\mathbf{U}$ & 20 & & 200 & $\mathrm{pCi} / \mathrm{L}$ \\
\hline Europium-154 & GP & $\mathrm{U}$ & 20 & & 200 & $\mathrm{pCi} / \mathrm{L}$ \\
\hline Europium-154 & $\mathrm{CN}$ & $\mathrm{U}$ & 25 & & 200 & $\mathrm{pCi} / \mathrm{L}$ \\
\hline Europium-155 & GP & $\mathbf{U}$ & 30 & & 600 & $\mathrm{pCi} / \mathrm{L}$ \\
\hline Europium-155 & GP & $\mathrm{U}$ & 30 & & 600 & $\mathrm{pCi} / \mathrm{L}$ \\
\hline Europium-155 & $\mathrm{CN}$ & $\mathrm{U}$ & 25 & & 600 & $\mathrm{pCi} / \mathrm{L}$ \\
\hline Fluoride & GE & $\mathbf{U}$ & 0.1 & & 4 & $\mathrm{mg} / \mathrm{L}$ \\
\hline Fluoride & GE & $\mathrm{U}$ & 0.1 & & 4 & $\mathrm{mg} / \mathrm{L}$ \\
\hline Fluoride & WA & $\mathrm{U}$ & 0.1 & & 4 & $\mathrm{mg} / \mathrm{L}$ \\
\hline Gross alpha & $\mathrm{GE}$ & & 28 & 13 & 15 & $\mathrm{pCi} / \mathrm{L}$ \\
\hline Gross alpha & GE & & 10 & 4.2 & 15 & $\mathrm{pCi} / \mathrm{L}$ \\
\hline Gross alpha & $\mathrm{CN}$ & & 48.8 & 1.48 & 15 & $\mathrm{pCi} / \mathrm{L}$ \\
\hline Gross alpha & TM & & 11.8 & 4.3 & 15 & $\mathrm{pCi} / \mathrm{L}$ \\
\hline Hardness & $\mathbf{G E}$ & & 19 & & & $\mathrm{mg} / \mathrm{L}$ \\
\hline Hardness & GE & & 20 & & & $\mathrm{mg} / \mathrm{L}$ \\
\hline Iodine-129 & $\mathrm{TE}$ & & 16 & 2.1 & 1 & $\mathrm{pCi} / \mathrm{L}$ \\
\hline Iodine-129 & $\mathrm{TE}$ & & 13.2 & 2 & 1 & $\mathrm{pCi} / \mathrm{L}$ \\
\hline Iodine -129 & $\mathrm{CN}$ & $\mathbf{U}$ & 2 & & 1 & $\mathrm{pCi} / \mathrm{L}$ \\
\hline Iron & GE & & 2570 & & 300 & $\mu g / L$ \\
\hline Iron & GE & & 3640 & & 300 & $\mu g / L$ \\
\hline Iron & WA & v & 9840 & & 300 & $\mu g / L$ \\
\hline Lead & GE & & 6.71 & & 15 & $\mu g / L$ \\
\hline
\end{tabular}


(Table 26. Continued)

\begin{tabular}{|c|c|c|c|c|c|c|}
\hline Analyte & Lab & Mod & $\begin{array}{c}7 / 92 \\
\text { Result }\end{array}$ & Ace & Standard & Units \\
\hline Lead & $\overline{G E}$ & & 7.53 & & 15 & $\mu g / L$ \\
\hline Lead & WA & $\mathrm{v}$ & 20.5 & & 15 & $\mu g / L$ \\
\hline Magnesium & $\mathrm{GE}$ & & 1210 & & & $\mu g / L$ \\
\hline Magnesium & GE & & 1350 & & & $\mu g / L$ \\
\hline Magnesium & WA & V & 1380 & & & $\mu g / L$ \\
\hline Manganese & $\mathrm{GE}$ & & 83.8 & & 50 & $\mu g / L$ \\
\hline Manganese & GE & . & 98.3 & & 50 & $\mu g / L$ \\
\hline Manganese & WA & & 164 & & 50 & $\mu g / L$ \\
\hline Mangarese-54 & GP & $\mathrm{U}$ & 10 & & 300 & $\mathrm{pCi} / \mathrm{L}$ \\
\hline Manganese- 54 & GP & $\mathrm{U}$ & 10 & & 300 & $\mathrm{pCi} / \mathrm{L}$ \\
\hline Manganese- 54 & $\mathrm{CN}$ & $\mathrm{U}$ & 10 & & 300 & $\mathrm{pCi} / \mathrm{L}$ \\
\hline Mercury & $\mathrm{GE}$ & & 1.43 & & 2 & $\mu \mathrm{g} / \mathrm{L}$ \\
\hline Mercury & GE & & 2.38 & & 2 & $\mu \mathrm{g} / \mathrm{L}$ \\
\hline Mercury & WA & & 1.27 & & 2 & $\mu \mathrm{g} / \mathrm{L}$ \\
\hline Neptunium-237 & $\mathrm{TE}$ & $\mathbf{U}$ & 10 & & 7.06 & $\mathrm{pCi} / \mathrm{L}$ \\
\hline Neptunium-237 & TE & $\mathrm{U}$ & 10 & & 7.06 & $\mathrm{pC} / / \mathrm{L}$ \\
\hline Neptunium-237 & $\mathrm{CN}$ & $\mathbf{U}$ & 45 & & 7.06 & $\mathrm{pCi} / \mathrm{L}$ \\
\hline Neptunium-237 & $\mathrm{CN}$ & $\mathrm{U}$ & 1 & & 7.06 & $\mathrm{pCi} / \mathrm{L}$ \\
\hline Nickel & GE & & 4.59 & & 100 & $\mu g / L$ \\
\hline Nickel & GE & & 8.32 & & 100 & $\mu \mathrm{g} / \mathrm{L}$ \\
\hline Nickel & WA & J3 & 8 & & 100 & $\mu g / L$ \\
\hline Nitrate as nitrogen & GE & & 19.9 & & 10 & $\mathrm{mg} / \mathrm{L}$ \\
\hline Nitrate as nitrogen & GE & & 20.2 & & 10 & $\mathrm{mg} / \mathrm{L}$ \\
\hline Nitrate as nitrogen & WA & & 15.3 & & 10 & $\mathrm{mg} / \mathrm{L}$ \\
\hline Nonvolatile beta & $\mathrm{GE}$ & & 80.2 & 13 & 50 & $\mathrm{pCi} / \mathrm{L}$ \\
\hline Nonvolatile beta & GE & & 32.6 & 5 & 50 & $\mathrm{pCi} / \mathrm{L}$ \\
\hline Nonvolatile beta & $\mathrm{CN}$ & & 46.8 & 1.79 & 50 & $\mathrm{pCi} / \mathrm{L}$ \\
\hline Nonvolatile beta & TM & & 64.9 & 7.3 & 50 & $\mathrm{pCi} / \mathrm{L}$ \\
\hline Plutonium-238 & GP & $\mathrm{U}$ & 1 & & 7.02 & $\mathrm{pC} i / \mathrm{L}$ \\
\hline Plutonium-238 & GP & U & 1 & & 7.02 & $\mathrm{pCi} / \mathrm{L}$ \\
\hline Plutonium-238 & $\mathrm{CN}$ & & 1.17 & 0.5 & 7.02 & $\mathrm{pCi} / \mathrm{L}$ \\
\hline Plutonium-239,240 & GP & $\mathrm{U}$ & 1 & & 62.1 & $\mathrm{pCi} / \mathrm{L}$ \\
\hline Plutonium-239,240 & GP & $\mathrm{U}$ & 1 & & 62.1 & $\mathrm{pCi} / \mathrm{L}$ \\
\hline Plutonium-239,240 & $\mathrm{CN}$ & $\mathbf{U}$ & 1 & & 62.1 & $\mathrm{pCi} / \mathrm{L}$ \\
\hline Potassium & $G E$ & & 810 & & & $\mu g / L$ \\
\hline Potassium & $\mathrm{GE}$ & & 941 & & & $\mu g / L$ \\
\hline Potassium & WA & v & 873 & & & $\mu g / L$ \\
\hline Potassium-40 & GP & U & 110 & & 300 & $\mathrm{pCi} / \mathrm{L}$ \\
\hline Potassium-40 & GP & U & 110 & & 300 & $\mathrm{pCi} / \mathrm{L}$ \\
\hline Potassium-40 & $\mathrm{CN}$ & $U$ & 175 & & 300 & $\mathrm{pCi} / \mathrm{L}$ \\
\hline Promethium-144 & GP & $\mathrm{U}$ & 10 & & & $\mathrm{pCi} / \mathrm{L}$ \\
\hline Promethium-144 & GP & $\mathrm{U}$ & 10 & & & $\mathrm{pCi} / \mathrm{L}$ \\
\hline Promethium-144 & $\mathrm{CN}$ & $\mathrm{U}$ & 10 & & & $\mathrm{pCi} / \mathrm{L}$ \\
\hline Promethium-146 & GP & $\mathrm{U}$ & 10 & & & $\mathrm{pCi} / \mathrm{L}$ \\
\hline Promethium-146 & GP & $\mathrm{U}$ & 10 & & & $\mathrm{pCi} / \mathrm{L}$ \\
\hline Promethium-146 & $\mathrm{CN}$ & $\mathrm{U}$ & 20 & & & $\mathrm{pCi} / \mathrm{L}$ \\
\hline Radium-226 & GP & & 4.95 & 0.45 & 15.7 & $\mathrm{pCi} / \mathrm{L}$ \\
\hline Radium-226 & GP & & 4.51 & 0.37 & 15.7 & $\mathrm{pCi} / \mathrm{L}$ \\
\hline Radium-226 & $\mathrm{CN}$ & $\mathrm{U}$ & 175 & & 15.7 & $\mathrm{pCi} / \mathrm{L}$ \\
\hline
\end{tabular}


(Table 26. Continued)

\begin{tabular}{|c|c|c|c|c|c|c|}
\hline \multirow[b]{2}{*}{ Analyte } & \multicolumn{5}{|c|}{$7 / 92$} & \multirow[b]{2}{*}{ Units } \\
\hline & Lab & Mod & Result & $A \propto$ & Standard & \\
\hline Radium-226 & $\mathrm{CN}$ & $\overline{\mathrm{U}}$ & 1 & & 15.7 & $\mathrm{pCi} / \mathrm{L}$ \\
\hline Radium-228 & GP & & 5.185 & 1.2 & 7.85 & $\mathrm{pCi} / \mathrm{L}$ \\
\hline Radium-228 & GP & & 2.17 & 1.5 & 7.85 & $\mathrm{pCi} / \mathrm{L}$ \\
\hline Radium-228 & $\mathrm{CN}$ & U & 1 & & 7.85 & $\mathrm{pCi} / \mathrm{L}$ \\
\hline Ruthenium-106 & GP & U & 90 & & 30 & $\mathrm{pCi} / \mathrm{L}$ \\
\hline Ruthenium-106 & GP & U & 90 & & 30 & $\mathrm{pCi} / \mathrm{L}$ \\
\hline Ruthenium-106 & $\mathrm{CN}$ & U & 70 & & 30 & pCi/L \\
\hline Selenium & GE & $\mathrm{U}$ & 2 & & 50 & $\mu \mathrm{g} / \mathrm{L}$ \\
\hline Selenium & GE & $\mathbf{U}$ & 2 & & 50 & $\mu \mathrm{g} / \mathrm{L}$ \\
\hline Selenium & WA & U & 2 & & 50 & $\mu \mathrm{g} / \mathrm{L}$ \\
\hline Silver & GE & $\mathrm{U}$ & 2 & & 50 & $\mu g / L$ \\
\hline Silver & GE & $\mathrm{U}$ & 2 & & 50 & $\mu g / L$ \\
\hline Silver & WA & U & 0.7 & & 50 & $\mu \mathrm{g} / \mathrm{L}$ \\
\hline Sodium & $\mathrm{GE}$ & & 59500 & & & $\mu g / L$ \\
\hline Sodium & $\mathrm{GE}$ & & 58700 & & & $\mu g / L$ \\
\hline Sodium & WA & & 37900 & & & $\mu g / L$ \\
\hline Sodium-22 & GP & U & 10 & & 466 & $\mathrm{pCi} / \mathrm{L}$ \\
\hline Sodium-22 & GP & U & 10 & & 466 & $\mathrm{pCi} / \mathrm{L}$ \\
\hline Sodium-22 & $\mathrm{CN}$ & U & 10 & & 466 & $\mathrm{pCi} / \mathrm{L}$ \\
\hline Strontium-90 & GP & U & 2 & & 8 & $\mathrm{pCi} / \mathrm{L}$ \\
\hline Strontium-90 & GP & U & 2 & & 8 & $\mathrm{pCi} / \mathrm{L}$ \\
\hline Strontium-90 & $\mathrm{CN}$ & $\mathrm{U}$ & 2 & & 8 & $\mathrm{pCi} / \mathrm{L}$ \\
\hline Technetium-99 & GP & & 13100 & 155 & 900 & $\mathrm{pCi} / \mathrm{L}$ \\
\hline Technetium-99 & GP & & 11800 & 130 & 900 & $\mathrm{pCi} / \mathrm{L}$ \\
\hline Technetium-99 & $\mathrm{CN}$ & R4 & & & 900 & $\mathrm{pCi} / \mathrm{L}$ \\
\hline Tetrachloroethylene & GE & $\mathrm{U}$ & 1 & & 5 & $\mu g / L$ \\
\hline Tetrachloroethylene & GE & $\mathrm{U}$ & 1 & & 5 & $\mu g / L$ \\
\hline Tetrachloroethylene & WA & U & 1 & & 5 & $\mu g / L$ \\
\hline Thallium & GE & U & 2 & & 1 & $\mu g / L$ \\
\hline Thallium & GE & $U$ & 2 & & 1 & $\mu g / L$ \\
\hline Thallium & WA & $\mathbf{U}$ & 2 & & 1 & $\mu g / L$ \\
\hline Thorium-228 & GP & $\mathrm{U}$ & 1 & & 125 & $\mathrm{pCi} / \mathrm{L}$ \\
\hline Thorium-228 & GP & $\mathrm{U}$ & 1 & & 125 & $\mathrm{pCi} / \mathrm{L}$ \\
\hline Thorium-228 & $\mathrm{CN}$ & $\mathbf{U}$ & 400 & & 125 & $\mathrm{pCi} / \mathrm{L}$ \\
\hline Thorium-228 & $\mathrm{CN}$ & $\mathbf{U}$ & 1 & & 125 & $\mathrm{pCi} / \mathrm{L}$ \\
\hline Thorium-230 & $G P$ & U & 1 & & 79.2 & $\mathrm{pCi} / \mathrm{L}$ \\
\hline Thorium-230 & GP & $\mathrm{U}$ & 1 & & 79.2 & $\mathrm{pCi} / \mathrm{L}$ \\
\hline Thorium-230 & $\mathrm{CN}$ & $\mathbf{U}$ & 1 & & 79.2 & $\mathrm{pCi} / \mathrm{L}$ \\
\hline Thorium-232 & GP & $\mathbf{U}$ & 1 & & 88 & $\mathrm{pCi} / \mathrm{L}$ \\
\hline Thorium-232 & GP & $\mathrm{U}$ & 1 & & 88 & $\mathrm{pCi} / \mathrm{L}$ \\
\hline Thorium-232 & $\mathrm{CN}$ & $\mathbf{U}$ & $i$ & & 88 & $\mathrm{pCi} / \mathrm{L}$ \\
\hline Tin & $\mathrm{GE}$ & $\mathbf{U}$ & 2 & & & $\mu g / L$ \\
\hline Tin & $\mathrm{GE}$ & & 6.81 & & & $\mu \mathrm{g} / \mathrm{L}$ \\
\hline Tin & WA & $\mathrm{J} 3$ & 6 & & & $\mu \mathrm{g} / \mathrm{L}$ \\
\hline Total organic carbon & $\mathrm{GE}$ & JQ & 19.9 & & & $\mathrm{mg} / \mathrm{L}$ \\
\hline Total organic carbon & $\mathrm{GE}$ & JQ & 29.5 & & & $\mathrm{mg} / \mathrm{L}$ \\
\hline Total organic carbon & WA & & 38.1 & & & $\mathrm{mg} / \mathrm{L}$ \\
\hline Total organic halogens & $\mathrm{GE}$ & JQ & 25.4 & & & $\mu g / L$ \\
\hline Total organic halogens & $\mathrm{GE}$ & JQ & 30.6 & & & $\mu \mathrm{g} / \mathrm{L}$ \\
\hline
\end{tabular}


(Table 26. Continued)

\begin{tabular}{|c|c|c|c|c|c|c|}
\hline Analyte & Lab & Mod & $\begin{array}{c}7 / 92 \\
\text { Result }\end{array}$ & Acc & Standard & Units \\
\hline Total organic halogens & WA & JQ & 22.25 & & & $\mu \mathrm{g} / \mathrm{L}$ \\
\hline Total phenols & GE & $\mathrm{U}$ & 5 & & & $\mu g / L$ \\
\hline Total phenols & GE & u & 5 & & & $\mu g / L$ \\
\hline Total phenols & WA & $\mathbf{U}$ & 5 & & & $\mu \mathrm{g} / \mathrm{L}$ \\
\hline Trichloroethylene & GE & $\mathrm{U}$ & 1 & & 5 & $\mu g / L$ \\
\hline Trichloroethylene & $\mathrm{GE}$ & $\mathrm{U}$ & 1 & & 5 & $\mu g / L$ \\
\hline Trichloroethylene & WA & $\mathrm{U}$ & 1 & & 5 & $\mu g / L$ \\
\hline Tritium & GE & & 4910 & 10 & 20 & $\mathrm{pCi} / \mathrm{ml}$ \\
\hline Tritium & $\mathrm{GE}$ & & 5730 & 11 & 20 & $\mathrm{pCi} / \mathrm{ml}$ \\
\hline Uranium-234 & GP & $\mathrm{U}$ & 1 & & 13.9 & $\mathrm{pCi} / \mathrm{L}$ \\
\hline Uranium-234 & GP & $\mathrm{U}$ & 1 & & 13.9 & $\mathrm{pCi} / \mathrm{L}$ \\
\hline Uranium-234 & $\mathrm{CN}$ & $\mathbf{U}$ & 1 & & 13.9 & $\mathrm{pCi} / \mathrm{L}$ \\
\hline Uranium-235 & GP & $\mathrm{U}$ & 1 & & 14.5 & $\mathrm{pCi} / \mathrm{L}$ \\
\hline Uranium-235 & GP & $\mathbf{u}$ & 1 & & 14.5 & $\mathrm{pCi} / \mathrm{L}$ \\
\hline Uranium-235 & $\mathrm{CN}$ & U & 15 & & 14.5 & $\mathrm{pCi} / \mathrm{L}$ \\
\hline Uranium-235 & $\mathrm{CN}$ & $\mathbf{U}$ & 1 & & 14.5 & $\mathrm{pCi} / \mathrm{L}$ \\
\hline Uranium-238 & GP & $\mathbf{U}$ & 1 & & 14.6 & $\mathrm{pCi} / \mathrm{L}$ \\
\hline Uranium-238 & GP & $\mathbf{U}$ & 1 & & 14.6 & $\mathrm{pCi} / \mathrm{L}$ \\
\hline Uranium-238 & $\mathrm{CN}$ & $\mathrm{U}$ & 1 & & 14.6 & $\mathrm{pCi} / \mathrm{L}$ \\
\hline Vanadium & GE & & 15.2 & & & $\mu g / L$ \\
\hline Vanadium & GE & & 20.8 & & & $\mu \mathrm{g} / \mathrm{L}$ \\
\hline Vanadium & WA & $\mathrm{v}$ & 70.2 & & & $\mu g / L$ \\
\hline Yttrium-88 & GP & U & 60 & & & $\mathrm{pCi} / \mathrm{L}$ \\
\hline Yttrium-88 & GP & $\mathrm{U}$ & 60 & & & $\mathrm{pCi} / \mathrm{L}$ \\
\hline Yttrium-88 & $\mathrm{CN}$ & $\mathrm{U}$ & 10 & & & $\mathrm{pCi} / \mathrm{L}$ \\
\hline Zinc & GE & & 119 & & & $\mu g / L$ \\
\hline Zinc & GE & & 131 & & & $\mu g / L$ \\
\hline Zinc & WA & & 93.1 & & & $\mu g / L$ \\
\hline Zinc-65 & GP & $\mathrm{U}$ & 20 & & 300 & $\mathrm{pCi} / \mathrm{L}$ \\
\hline Zinc-65 & GP & $\mathrm{U}$ & 20 & & 300 & $\mathrm{pC} i / \mathrm{L}$ \\
\hline Zinc-65 & $\mathrm{CN}$ & $\mathrm{U}$ & 20 & & 300 & $\mathrm{pCi} / \mathrm{L}$ \\
\hline
\end{tabular}


Table 27. HSP029 Laboratory Analyses

Field Measurements:

Sample Date: 07/21/92

pH: 4.80

Specific Conductance: $97 \mu \mathrm{S} / \mathrm{cm}$

\begin{tabular}{|c|c|c|c|c|c|c|}
\hline Analyte & Lab & Mod & $\begin{array}{c}7 / 92 \\
\text { Result }\end{array}$ & $A \propto c$ & Standard & Units \\
\hline 1,1,1-Trichloroethane & GE & $\bar{U}$ & 1 & & 200 & $\mu g / L$ \\
\hline Alkalinity & GE & V & 1.5 & & & $\mathrm{mg} / \mathrm{L}$ \\
\hline Aluminum & GE & & 606 & & & $\mu \mathrm{g} / \mathrm{L}$ \\
\hline Americium-241 & GP & $\mathbf{U}$ & 1 & & 6.34 & $\mathrm{pCi} / \mathrm{L}$ \\
\hline Ammonia nitrogen & GE & U & 0.1 & & & $\mathrm{mg} / \mathrm{L}$ \\
\hline Antimony & GE & $\mathrm{U}$ & 2 & & 5 & $\mu \mathrm{g} / \mathrm{L}$ \\
\hline Antimony-125 & GP & $\mathbf{U}$ & 20 & & 300 & $\mathrm{pCi} / \mathrm{L}$ \\
\hline Arsenic & GE & U & 2 & & 50 & $\mu g / L$ \\
\hline Barium & GE & & 68.7 & & 2000 & $\mu g / L$ \\
\hline Beryllium & $G E$ & U & 3 & & 1 & $\mu g / L$ \\
\hline Cadmium & $\mathrm{GE}$ & $\mathrm{U}$ & 2 & & 5 & $\mu g / L$ \\
\hline Calcium & $\mathrm{GE}$ & & 1820 & & & $\mu g / L$ \\
\hline Carbon tetrachloride & $\mathrm{GE}$ & U & 1 & & 5 & $\mu g / L$ \\
\hline Cerium-144 & GP & $\mathbf{U}$ & 60 & & 261 & $\mathrm{pCi} / \mathrm{L}$ \\
\hline Cesium-134 & GP & $\mathbf{U}$ & 10 & & 81.3 & $\mathrm{pCi} / \mathrm{L}$ \\
\hline Cesium-137 & GP & $\mathbf{U}$ & 10 & & 200 & $\mathrm{pCi} / \mathrm{L}$ \\
\hline Chloride & $\mathrm{GE}$ & & 2.38 & & & $\mathrm{mg} / \mathrm{L}$ \\
\hline Chloroform & $\mathrm{GE}$ & $\mathbf{u}$ & 1 & & 100 & $\mu g / L$ \\
\hline Chromium & $\mathrm{GE}$ & $\mathrm{U}$ & 4 & & 100 & $\mu g / L$ \\
\hline Cobalt-57 & GP & $\mathbf{U}$ & 10 & & 1000 & $\mathrm{pCi} / \mathrm{L}$ \\
\hline Cobalt-60 & GP & & 64.4 & 8 & 100 & $\mathrm{pCi} / \mathrm{L}$ \\
\hline Copper & $\mathrm{GE}$ & U & 4 & & 1300 & $\mu g / L$ \\
\hline Curium-242 & GP & $\mathrm{U}$ & 1 & & 0.133 & $\mathrm{pCi} / \mathrm{L}$ \\
\hline Curium-243,244 & GP & $\mathrm{U}^{\circ}$ & 1 & & 8.3 & $\mathrm{pCi} / \mathrm{L}$ \\
\hline Europium-152 & GP & $\mathbf{U}$ & 40 & & & $\mathrm{pCi} / \mathrm{L}$ \\
\hline Europium-154 & GP & $\mathrm{U}$ & 20 & & 200 & $\mathrm{pCi} / \mathrm{L}$ \\
\hline Europium-155 & GP & U & 30 & & 600 & $\mathrm{pCi} / \mathrm{L}$ \\
\hline Fluoride & $\mathrm{GE}$ & $\mathrm{U}$ & 0.1 & & 4 & $\mathrm{mg} / \mathrm{L}$ \\
\hline Gross alpha & GE & $\mathrm{U}$ & 2 & & 15 & $\mathrm{pCi} / \mathrm{L}$ \\
\hline Hardness & $\mathrm{GE}$ & & 13.4 & & & $\mathrm{mg} / \mathrm{L}$ \\
\hline Iodine-129 & $\mathrm{TE}$ & & 7.8 & 1.2 & 1 & $\mathrm{pCi} / \mathrm{L}$ \\
\hline Iron & $\mathrm{GE}$ & & 19.7 & & 300 & $\mu g / L$ \\
\hline Lead & GE & U & 3 & & 15 & $\mu g / L$ \\
\hline Magnesium & $\mathrm{GE}$ & & 1730 & & & $\mu \mathrm{g} / \mathrm{L}$ \\
\hline Manganese & $\mathrm{GE}$ & & 527 & & 50 & $\mu g / L$ \\
\hline Manganese-54 & GP & U & 10 & & 300 & $\mathrm{pCi} / \mathrm{L}$ \\
\hline Mercury & $\mathrm{GE}$ & U & 0.2 & & 2 & $\mu g / L$ \\
\hline Neptunium-237 & $\mathrm{TE}$ & $\mathbf{U}$ & 10 & & 7.06 & $\mathrm{pCi} / \mathrm{L}$ \\
\hline Nickel & $\mathrm{GE}$ & & 7.47 & & 100 & $\mu \mathrm{g} / \mathrm{L}$ \\
\hline Nitrate as nitrogen & $\mathrm{GE}$ & & 12.2 & & 10 & $\mathrm{mg} / \mathrm{L}$ \\
\hline Nonvolatile beta & GE & $\mathrm{v}$ & 1070 & 18 & 50 & $\mathrm{pCi} / \mathrm{L}$ \\
\hline Plutonium-238 & $\mathrm{GP}$ & U & 1 & & 7.02 & $\mathrm{pCi} / \mathrm{L}$ \\
\hline Plutonium-239,240 & GP & $\mathrm{U}$ & 1 & & 62.1 & $\mathrm{pCi} / \mathrm{L}$ \\
\hline Potassium & $\mathrm{GE}$ & & 943 & & & $\mu g / L$ \\
\hline Potassium-40 & GP & U & 110 & & 300 & $\mathrm{pCi} / \mathrm{L}$ \\
\hline Promethium-144 & GP & $\mathrm{U}$ & 10 & & & $\mathrm{pCi} / \mathrm{L}$ \\
\hline
\end{tabular}


(Table 27. Continued)

\begin{tabular}{|c|c|c|c|c|c|c|}
\hline Analyte & $\mathbf{L a b}$ & Mod & $\begin{array}{c}7 / 92 \\
\text { Result }\end{array}$ & Acc & Standard & Units \\
\hline Promethium-146 & GP & $\bar{U}$ & 10 & & & $\mathrm{pCi} / \mathrm{L}$ \\
\hline Radium-226 & GP & & 1.17 & 0.23 & 15.7 & $\mathrm{pCi} / \mathrm{L}$ \\
\hline Radium-228 & GP & & 523 & 7.4 & 7.85 & $\mathrm{pC} / \mathrm{i} /$ \\
\hline Ruthenium-106 & GP & $\mathrm{U}$ & 90 & & 30 & $\mathrm{pCi} / \mathrm{L}$ \\
\hline Selenium & $\mathrm{GE}$ & UJ1 & 2 & & 50 & $\mu g / L$ \\
\hline Silver & GE & $\mathbf{U}$ & 2 & & 50 & $\mu g / L$ \\
\hline Sodium & GE & & 12700 & & & $\mu g / L$ \\
\hline Sodium-22 & GP & U & 10 & & 466 & $\mathrm{pCi} / \mathrm{L}$ \\
\hline Strontium-90 & GP & & 549 & 8.4 & 8 & $\mathrm{pCi} / \mathrm{L}$ \\
\hline Technetium-99 & GP & & 1910 & 68 & 900 & $\mathrm{pCi} / \mathrm{L}$ \\
\hline Tetrachloroethylene & GE & $\mathrm{U}$ & 1 & & 5 & $\mu \mathrm{g} / \mathrm{L}$ \\
\hline Thallium & GE & $\mathrm{U}$ & 2 & & 1 & $\mu \mathrm{g} / \mathrm{L}$ \\
\hline Thorium-228 & $\mathrm{GP}$ & $\mathrm{U}$ & 1 & & 125 & $\mathrm{pCi} / \mathrm{L}$ \\
\hline Thorium-230 & GP & U & 1 & & 79.2 & $\mathrm{pCi} / \mathrm{L}$ \\
\hline Thorium-232 & $\mathrm{GP}$ & $\mathrm{U}$ & 1 & & 88 & $\mathrm{pCi} / \mathrm{L}$ \\
\hline Tin & $\mathrm{GE}$ & $\mathrm{U}$ & 2 & & & $\mu g / L$ \\
\hline Total organic carbon & GE & & 2.63 & & & $\mathrm{mg} / \mathrm{L}$ \\
\hline Total organic halogens & GE & $\mathbf{U}$ & 5 & & & $\mu g / L$ \\
\hline Total phenols & GE & $\mathrm{U}$ & 5 & & & $\mu g / L$ \\
\hline Trichloroethylene & GE & $\mathrm{U}$ & 1 & & 5 & $\mu g / L$ \\
\hline Tritium & GE & & 858 & 4.4 & 20 & $\mathrm{pCi} / \mathrm{ml}$ \\
\hline Uranium-234 & GP & $\mathrm{U}$ & 1 & & 13.9 & $\mathrm{pCi} / \mathrm{L}$ \\
\hline Uranium-235 & GP & $\mathrm{U}$ & 1 & & 14.5 & $\mathrm{pCi} / \mathrm{L}$ \\
\hline Uranium-238 & GP & $\mathrm{U}$ & 1 & & 14.6 & $\mathrm{pCi} / \mathrm{L}$ \\
\hline Vanadium & GE & $\mathrm{U}$ & 8 & & & $\mu g / L$ \\
\hline Yttrium-88 & GP & $\mathrm{U}$ & 60 & & & $\mathrm{pCi} / \mathrm{L}$ \\
\hline Zinc & $\mathrm{GE}$ & & 77.3 & & & $\mu g / L$ \\
\hline Zinc-65 & GP & $\mathrm{U}$ & 20 & & 300 & $\mathrm{pCi} / \mathrm{L}$ \\
\hline
\end{tabular}


Table 28. HSP043 Laboratory Analyses

Field Measurements:

Sample Date: 07/23/92

pH: 5.73

Specific Conductance: $155 \mu \mathrm{S} / \mathrm{cm}$

\begin{tabular}{|c|c|c|c|c|c|c|c|c|}
\hline Analyte & Lab & Mod & $\begin{array}{c}7 / 92 \\
\text { Result }\end{array}$ & Acc & Standard & Mod & Result & Units \\
\hline 1,1,1-Trichloroethane & GE & $\mathrm{U}$ & 1 & & 200 & & & $\mu \mathrm{g} / \mathrm{L}$ \\
\hline 1,1,1-Trichloroethane & WA & $\mathbf{U}$ & 1 & & 200 & & & $\mu \mathrm{g} / \mathrm{L}$ \\
\hline Alkalinity & GE & & 42.5 & & & & 148 & $\mathrm{mg} / \mathrm{L}$ \\
\hline Aluminum & GE & & 4440 & & & & 80 & $\mu \mathrm{g} / \mathrm{L}$ \\
\hline Aluminum & WA & $\mathbf{V}$ & 4820 & & & & & $\mu \mathrm{g} / \mathrm{L}$ \\
\hline Americium-241 & GP & $\mathbf{U}$ & 1 & & 6.34 & & & $\mathrm{pCi} / \mathrm{L}$ \\
\hline Americium-241 & $\mathrm{CN}$ & $\mathbf{U}$ & 1 & & 6.34 & & & $\mathrm{pCi} / \mathrm{L}$ \\
\hline Ammonia nitrogen & GE & & 0.21 & & & & & $\mathrm{mg} / \mathrm{L}$ \\
\hline Antimony & $\mathrm{GE}$ & $\mathbf{U}$ & 2 & & 5 & & & $\mu \mathrm{g} / \mathrm{L}$ \\
\hline Antimony & WA & $\mathbf{U}$ & 2.6 & & 5 & & & $\mu g / L$ \\
\hline Antimony-125 & GP & $\mathbf{U}$ & 20 & & 300 & & & $\mathrm{pCi} / \mathrm{L}$ \\
\hline Antimony-125 & $\mathrm{CN}$ & U & 20 & & 300 & & & $\mathrm{pCi} / \mathrm{L}$ \\
\hline Arsenic & $\mathrm{GE}$ & U & 2 & & 50 & U & 3 & $\mu g / L$ \\
\hline Arsenic & WA & U & 2 & & 50 & & & $\mu \mathrm{g} / \mathrm{L}$ \\
\hline Barium & GE & & 17.8 & & 2000 & & & $\mu g / L$ \\
\hline Barium & WA & J3 & 13.4 & & 2000 & & & $\mu g / L$ \\
\hline Beryllium & GE & $\mathbf{U}$ & 3 & & 1 & & & $\mu \mathrm{g} / \mathrm{L}$ \\
\hline Beryllium & WA & U & 0.18 & & 1 & & & $\mu g / L$ \\
\hline Cadmium & GE & $\mathrm{U}$ & 2 & & 5 & $\mathrm{U}$ & 6 & $\mu \mathrm{g} / \mathrm{L}$ \\
\hline Cadmium & WA & $\mathrm{J} 3$ & 1.3 & & 5 & . & & $\mu \mathrm{g} / \mathrm{L}$ \\
\hline Calcium & GE & $\mathrm{J} 2$ & 833 & & & & & $\mu g / L$ \\
\hline Calcium & WA & & 524 & & & & & $\mu g / L$ \\
\hline Carbon tetrachloride & GE & $\mathbf{U}$ & 1 & & 5 & & & $\mu g / L$ \\
\hline Carbon tetrachloride & WA & $\mathbf{U}$ & 1 & & 5 & & & $\mu g / L$ \\
\hline Cerium-144 & GP & $\mathrm{U}$ & 60 & & 261 & & & $\mathrm{pCi} / \mathrm{L}$ \\
\hline Cerium-144 & $\mathrm{CN}$ & U & 50 & & 261 & & & $\mathrm{pCi} / \mathrm{L}$ \\
\hline Cesium-134 & GP & $\mathbf{U}$ & 10 & & 81.3 & $\mathrm{U}$ & 6.5 & $\mathrm{pCi} / \mathrm{L}$ \\
\hline Cesium-134 & $\mathrm{CN}$ & $\mathbf{U}$ & 10 & & 81.3 & & & $\mathrm{pCi} / \mathrm{L}$ \\
\hline Cesium-137 & GP & $\mathrm{U}$ & 10 & & 200 & & 4.4 & $\mathrm{pCi} / \mathrm{L}$ \\
\hline Cesium-137 & $\mathrm{CN}$ & $\mathbf{U}$ & 10 & & 200 & & & $\mathrm{pCi} / \mathrm{L}$ \\
\hline Chloride & GE & & 3.94 & & & & 1.2 & $\mathrm{mg} / \mathrm{L}$ \\
\hline Chloride & WA & & 5.94 & & & & & $\mathrm{mg} / \mathrm{L}$ \\
\hline Chloroform & GE & $\mathbf{U}$ & 1 & & 100 & & & $\mu g / L$ \\
\hline Chloroform & WA & $\mathbf{U}$ & 1 & & 100 & & & $\mu g / L$ \\
\hline Chromium & GE & & 5.07 & & 100 & $\mathrm{U}$ & 7 & $\mu \mathrm{g} / \mathrm{L}$ \\
\hline Chromium & WA & $\mathrm{J3}$ & 3.7 & & 100 & & & $\mu \mathrm{g} / \mathrm{L}$ \\
\hline Cobalt-57 & GP & $\mathbf{U}$ & 10 & & 1000 & & & $\mathrm{pCi} / \mathrm{L}$ \\
\hline Cobalt-57 & $\mathrm{CN}$ & $\mathbf{U}$ & 10 & & 1000 & & & $\mathrm{pCi} / \mathrm{L}$ \\
\hline Cobalt- 60 & GP & $\mathbf{U}$ & 10 & & 100 & & 64 & $\mathrm{pCi} / \mathrm{L}$ \\
\hline Cobalt-60 & $\mathrm{CN}$ & $\mathbf{U}$ & 10 & & 100 & & & $\mathrm{pCi} / \mathrm{L}$ \\
\hline Copper & $\mathrm{GE}$ & & 4.02 & & 1300 & & & $\mu g / L$ \\
\hline Copper & WA & $\mathrm{J3}$ & 1.7 & & 1300 & & & $\mu \mathrm{g} / \mathrm{L}$ \\
\hline Curium-242 & GP & $\mathbf{U}$ & 1 & & 0.133 & & & $\mathrm{pCi} / \mathrm{L}$ \\
\hline Curium-242 & $\mathrm{CN}$ & $\mathrm{U}$ & 1 & & 0.133 & & & $\mathrm{pCi} / \mathrm{L}$ \\
\hline Curium-243,244 & GP & $\mathrm{U}$ & 1 & & 8.3 & & & $\mathrm{pC} / / \mathrm{L}$ \\
\hline Curium-243,244 & $\mathrm{CN}$ & $\mathrm{U}$ & 1 & & 8.3 & & & $\mathrm{p} C \mathrm{i} / \mathrm{L}$ \\
\hline
\end{tabular}


(Table 28. Continued)

\begin{tabular}{|c|c|c|c|c|c|c|c|c|}
\hline Analyte & Lab & Mod & $\begin{array}{c}7 / 92 \\
\text { Result }\end{array}$ & $A \propto$ & Standard & Mod & Result & Units \\
\hline Europium-152 & GP & $\mathbf{U}$ & 40 & & & & & $\mathrm{pCi} / \mathrm{L}$ \\
\hline Europium-152 & $\mathrm{CN}$ & $\mathrm{U}$ & 40 & & & & & $\mathrm{pCi} / \mathrm{L}$ \\
\hline Europium-154 & GP & $\mathbf{U}$ & 20 & & 200 & & & $\mathrm{pCi} / \mathrm{L}$ \\
\hline Europium-154 & $\mathrm{CN}$ & $\mathbf{U}$ & 25 & & 200 & & & $\mathrm{pCi} / \mathrm{L}$ \\
\hline Europium-155 & GP & $\mathbf{U}$ & 30 & & 600 & & & $\mathrm{pCi} / \mathrm{L}$ \\
\hline Europium-155 & $\mathrm{CN}$ & $\mathbf{U}$ & 25 & & 600 & & & $\mathrm{pCi} / \mathrm{L}$ \\
\hline Fluoride & $\mathrm{GE}$ & $\mathbf{U}$ & 0.1 & & 4 & & & $\mathrm{mg} / \mathrm{L}$ \\
\hline Fluoride & WA & $\mathbf{U}$ & 0.1 & & 4 & & & $\mathrm{mg} / \mathrm{L}$ \\
\hline Gross alpha & $\mathrm{GE}$ & & 14.7 & 4.8 & 15 & & 33 & $\mathrm{pCi} / \mathrm{L}$ \\
\hline Gross alpha & $\mathrm{CN}$ & & 72 & 1.92 & 15 & & & $\mathrm{pCi} / \mathrm{L}$ \\
\hline Gross alpha & TM & & 7.25 & 3.35 & 15 & & & $\mathrm{pCi} / \mathrm{L}$ \\
\hline Hardness & GE & & 7.8 & & & & 73.3 & $\mathrm{mg} / \mathrm{L}$ \\
\hline Iodine-129 & $\mathrm{TE}$ & & 52.2 & 3.1 & 1 & $\mathbf{U}$ & 39 & $\mathrm{pCi} / \mathrm{L}$ \\
\hline Iodine-129 & $\mathrm{CN}$ & U & 2 & & 1 & & & $\mathrm{pCi} / \mathrm{L}$ \\
\hline Iron & GE & & 1920 & & 300 & & & $\mu \mathrm{g} / \mathrm{L}$ \\
\hline Iron & WA & $\mathbf{V}$ & 3240 & & 300 & & & $\mu g / L$ \\
\hline Lead & $\mathrm{GE}$ & & 8.68 & & 15 & $\mathrm{U}$ & 3 & $\mu g / L$ \\
\hline Lead & WA & $\mathrm{V}$ & 18 & & 15 & & & $\mu \mathrm{g} / \mathrm{L}$ \\
\hline Magnesium & $\mathrm{GE}$ & & 379 & & & & & $\mu g / L$ \\
\hline Magnesium & WA & V & 252 & & & & & $\mu g / L$ \\
\hline Manganese & GE & & 28.5 & & 50 & & & $\mu g / \mathrm{L}$ \\
\hline Manganese & WA & & 17.9 & & 50 & & & $\mu g / L$ \\
\hline Manganese-54 & GP & $\mathbf{U}$ & 10 & & 300 & & & $\mathrm{pCi} / \mathrm{L}$ \\
\hline Manganese-54 & $\mathrm{CN}$ & $\mathrm{U}$ & 10 & & 300 & & & $\mathrm{pC} \mathbf{i} / \mathrm{L}$ \\
\hline Mercury & GE & & 0.94 & & 2 & $U$ & 0.2 & $\mu g / L$ \\
\hline Mercury & WA & & 1.68 & & 2 & & & $\mu \mathrm{g} / \mathrm{L}$ \\
\hline Neptunium-237 & TE & $\mathbf{U}$ & 10 & & 7.06 & $\mathrm{U}$ & 1 & $\mathrm{pCi} / \mathrm{L}$ \\
\hline Neptunium-237 & $\mathrm{CN}$ & $\mathbf{U}$ & 45 & & 7.06 & & & $\mathrm{pCi} / \mathrm{L}$ \\
\hline Neptunium-237 & $\mathrm{CN}$ & $\mathrm{U}$ & 1 & & 7.06 & & & $\mathrm{pCi} / \mathrm{L}$ \\
\hline Nickel & GE & $\mathbf{U}$ & 4 & & 100 & $\mathbf{U}$ & 34 & $\mu g / L$ \\
\hline Nickel & WA & $\mathrm{U}$ & 3.1 & & 100 & & & $\mu \mathrm{g} / \mathrm{L}$ \\
\hline Nitrate as nitrogen & GE & & 2.4 & & 10 & & 8.9 & $\mathrm{mg} / \mathrm{L}$ \\
\hline Nitrate as nitrogen & WA & & 5.18 & & 10 & & & $\mathrm{mg} / \mathrm{L}$ \\
\hline Nonvolatile beta & GE & & 23.8 & 4.4 & 50 & & 4800 & $\mathrm{pCi} / \mathrm{L}$ \\
\hline Nonvolatile beta & $\mathrm{CN}$ & & 66.5 & 1.91 & 50 & & & $\mathrm{pC} / / \mathrm{L}$ \\
\hline Nonvolatile beta & TM & & 59.55 & 7.1 & 50 & & & $\mathrm{pCi} / \mathrm{L}$ \\
\hline Plutonium-238 & GP & $\mathrm{U}$ & 1 & & 7.02 & $\mathrm{U}$ & 1 & $\mathrm{pC} / \Omega$ \\
\hline Plutonium-238 & $\mathrm{CN}$ & $\mathrm{U}$ & 1 & & 7.02 & & & $\mathrm{pCi} / \mathrm{L}$ \\
\hline Plutonium-239,240 & GP & $\mathbf{U}$ & 1 & & 62.1 & $U$ & 1 & $\mathrm{pCi} / \mathrm{L}$ \\
\hline Plutonium-239,240 & $\mathrm{CN}$ & $\mathbf{U}$ & 1 & & 62.1 & & & $\mathrm{pCi} / \mathrm{L}$ \\
\hline Potassium & $\mathrm{GE}$ & & 544 & & & & & $\mu \mathrm{g} / \mathrm{L}$ \\
\hline Potassium & WA & $\mathrm{J} 3 \mathrm{~V}$ & 378 & & & & & $\mu g / L$ \\
\hline Potassium-40 & GP & $\mathbf{U}$ & 110 & & 300 & & & $\mathrm{pC} / / L$ \\
\hline Potassium-40 & $\mathrm{CN}$ & $\mathbf{U}$ & 175 & & 300 & & & $\mathrm{pC} / / \mathrm{L}$ \\
\hline Promethium-144 & GP & $\mathbf{U}$ & 10 & & & & & $\mathrm{pC} i / L$ \\
\hline Promethium-144 & $\mathrm{CN}$ & $\mathbf{U}$ & 10 & & & & & $\mathrm{pCi} / \mathrm{L}$ \\
\hline Promethium-146 & GP & $\mathbf{U}$ & 10 & & & & & $\mathrm{pCi} / \mathrm{L}$ \\
\hline Promethium-146 & $\mathrm{CN}$ & $\mathbf{U}$ & 20 & & & & & $\mathrm{pCi} / \mathrm{L}$ \\
\hline Radium-226 & GP & & 3.88 & 0.37 & 15.7 & & 30 & $\mathrm{pCi} / \mathrm{L}$ \\
\hline
\end{tabular}


(Table 28. Continued)

\begin{tabular}{|c|c|c|c|c|c|c|c|c|}
\hline Analyte & Lab & Mod & $\begin{array}{c}7 / 92 \\
\text { Result }\end{array}$ & $A \infty$ & Standard & Mod & Result & Units \\
\hline Radium-226 & $\mathrm{CN}$ & $\mathrm{U}$ & 175 & & 15.7 & & & $\mathrm{pCi} / \mathrm{L}$ \\
\hline Radium-226 & $\mathrm{CN}$ & U & 1 & & 15.7 & & & $\mathrm{pCi} / \mathrm{L}$ \\
\hline Radium-228 & GP & & 1.17 & 0.82 & 7.85 & & & $\mathrm{pCi} / \mathrm{L}$ \\
\hline Radium-228 & $\mathrm{CN}$ & U & 1 & & 7.85 & & & $\mathrm{pCi} / \mathrm{L}$ \\
\hline Ruthenium-103 & $\mathrm{CN}$ & $\mathrm{U}$ & 10 & & & & & $\mathrm{pCi} / \mathrm{L}$ \\
\hline Ruthenium-106 & GP & $\mathrm{U}$ & 90 & & 30 & & & $\mathrm{pCi} / \mathrm{L}$ \\
\hline Ruthenium-106 & $\mathrm{CN}$ & U & 70 & & 30 & & & $\mathrm{pCi} / \mathrm{L}$ \\
\hline Selenium & $\mathrm{GE}$ & U & 2 & & 50 & U & 2 & $\mu g / L$ \\
\hline Selenium & WA & $\mathbf{U}$ & 2 & & 50 & & & $\mu g / L$ \\
\hline Silver & GE & U & 2 & & 50 & $\mathrm{U}$ & 4 & $\mu g / L$ \\
\hline Silver & WA & $\mathbf{U}$ & 0.7 & & 50 & & & $\mu \mathrm{g} / \mathrm{L}$ \\
\hline Sodium & GE & & 41900 & & & & 63.3 & $\mu g / L$ \\
\hline Sodium & WA & & 31100 & & & & & $\mu g / L$ \\
\hline Sodium-22 & GP & U & 10 & & 466 & & & $\mathrm{pCi} / \mathrm{L}$ \\
\hline Sodium-22 & $\mathrm{CN}$ & $\mathrm{U}$ & 10 & & 466 & & & $\mathrm{pCi} / \mathrm{L}$ \\
\hline Strontium-90 & GP & U & 2 & & 8 & & 1800 & $\mathrm{pCi} / \mathrm{L}$ \\
\hline Strontium-90 & $\mathrm{CN}$ & U & 2 & & 8 & & & $\mathrm{pCi} / \mathrm{L}$ \\
\hline Technetium-99 & GP & & 6080 & 100 & 900 & & 280 & $\mathrm{pCi} / \mathrm{L}$ \\
\hline Technetium-99 & $\mathrm{CN}$ & R4 & & & 900 & & & $\mathrm{pCi} / \mathrm{L}$ \\
\hline Tetrachloroethylene & GE & $\mathrm{U}$ & 1 & & 5 & & & $\mu g / L$ \\
\hline Tetrachloroethylene & WA & $\mathbf{U}$ & 1 & & 5 & & & $\mu g / L$ \\
\hline Thallium & GE & $\mathrm{U}$ & 2 & & 1 & & & $\mu \mathrm{g} / \mathrm{L}$ \\
\hline Thallium & WA & $\mathrm{U}$ & 2 & & 1 & & & $\mu g / L$ \\
\hline Thorium-228 & GP & $\mathrm{U}$ & 1 & & 125 & & & $\mathrm{pCi} / \mathrm{L}$ \\
\hline Thorium-228 & $\mathrm{CN}$ & $\mathrm{U}$ & 400 & & 125 & & & $\mathrm{pCi} / \mathrm{L}$ \\
\hline Thorium-228 & $\mathrm{CN}$ & $\mathbf{U}$ & 1 & & 125 & & & $\mathrm{pCi} / \mathrm{L}$ \\
\hline Thorium-230 & GP & $\mathrm{U}$ & 1 & & 79.2 & & & $\mathrm{pCi} / \mathrm{L}$ \\
\hline Thorium-230 & $\mathrm{CN}$ & $\mathrm{U}$ & 1 & & 79.2 & & & $\mathrm{pCi} / \mathrm{L}$ \\
\hline Thorium-232 & GP & $\mathrm{U}$ & 1 & & 88 & & & $\mathrm{pCi} / \mathrm{L}$ \\
\hline Thorium-232 & $\mathrm{CN}$ & $\mathbf{U}$ & 1 & & 88 & & & $\mathrm{pCi} / \mathrm{L}$ \\
\hline Tin & GE & $\mathbf{U}$ & 2 & & & & & $\mu g / L$ \\
\hline Tin & WA & $\mathbf{U}$ & 1.9 & & & & & $\mu g / L$ \\
\hline Total organic carbon & $G E$ & JQ & 40 & & & & & $\mathrm{mg} / \mathrm{L}$ \\
\hline Total organic carbon & WA & & 53.3 & & & & & $\mathrm{mg} / \mathrm{L}$ \\
\hline Total organic halogens & GE & JQ & 52.6 & & & & & $\mu g / L$ \\
\hline Total organic halogens & WA & JQ & 124 & & & & & $\mu g / L$ \\
\hline Total phenols & $\mathrm{GE}$ & U & 5 & & & & & $\mu g / L$ \\
\hline Total phenols & WA & $\mathrm{U}$ & 5 & & & & & $\mu \mathrm{g} / \mathrm{L}$ \\
\hline Trichloroethylene & GE & $\mathrm{U}$ & 1 & & 5 & & & $\mu \mathrm{g} / \mathrm{L}$ \\
\hline Triçhloroethylene & WA & $\mathrm{U}$ & 1 & & 5 & & & $\mu \mathrm{g} / \mathrm{L}$ \\
\hline Tritium & GE & & 3260 & 8.4 & 20 & & 16000 & $\mathrm{pCi} / \mathrm{ml}$ \\
\hline Uranium-234 & GP & $\mathbf{U}$ & 1 & & 13.9 & & & $\mathrm{pCi} / \mathrm{L}$ \\
\hline Uranium-234 & $\mathrm{CN}$ & $\mathbf{U}$ & 1 & & 13.9 & & & $\mathrm{pCi} / \mathrm{L}$ \\
\hline Uranium-235 & GP & $\mathbf{U}$ & 1 & & 14.5 & & & $\mathrm{pCi} / \mathrm{L}$ \\
\hline Uranium-235 & $\mathrm{CN}$ & $\mathbf{U}$ & 15 & & 14.5 & & & $\mathrm{pCi} / \mathrm{L}$ \\
\hline Uranium-235 & $\mathrm{CN}$ & $\mathrm{U}$ & 1 & & 14.5 & & & $\mathrm{pCi} / \mathrm{L}$ \\
\hline Uranium-238 & GP & $\mathbf{U}$ & 1 & & 14.6 & $\mathbf{U}$ & 1 & $\mathrm{pCi} / \mathrm{L}$ \\
\hline Uranium-238 & $\mathrm{CN}$ & $\mathbf{U}$ & 1 & & 14.6 & & & $\mathrm{pCi} / \mathrm{L}$ \\
\hline Vanadium & $\mathrm{GE}$ & $\mathbf{U}$ & 8 & & & & & $\mu g / L$ \\
\hline
\end{tabular}


WSRC-TR-93-289

(Table 28. Continued)

\begin{tabular}{|c|c|c|c|c|c|c|c|c|}
\hline Analyte & Lab & Mod & $\begin{array}{c}7 / 92 \\
\text { Result }\end{array}$ & Ace & Standard & Mod & Result & Units \\
\hline Vanadium & WA & $\mathrm{V}$ & 7.9 & & & & & $\mu g / L$ \\
\hline Yttrium-88 & GP & $\mathbf{U}$ & 60 & & & & & $\mathrm{pCi} / \mathrm{L}$ \\
\hline Yttrium-88 & $\mathrm{CN}$ & $\mathbf{U}$ & 10 & & & & & $\mathrm{pCi} / \mathrm{L}$ \\
\hline Zinc & $G E$ & & 199 & & & $\mathbf{U}$ & 9 & $\mu g / L$ \\
\hline Zinc & WA & & 37.8 & & & & & $\mu \mathrm{g} / \mathrm{L}$ \\
\hline Zinc-65 & GP & $U$ & 20 & & 300 & & & $p C i / L$ \\
\hline Zinc- 65 & $\mathrm{CN}$ & $\mathbf{U}$ & 20 & & 300 & & & $\mathrm{pCi} / \mathrm{L}$ \\
\hline
\end{tabular}


Table 29. HSP060 Laboratory Analyses

Field Measurements:

Sample Date: 07/21/92

pH: 6.07

Specific Conductance: $173 \mu \mathrm{S} / \mathrm{cm}$

\begin{tabular}{|c|c|c|c|c|c|c|}
\hline Analyte & $\mathbf{L a b}$ & Mod & $\begin{array}{c}7 / 92 \\
\text { Result } \\
\end{array}$ & $A \infty$ & Standard & Units \\
\hline 1,1,1-Trichloroethane & GE & $\bar{U}$ & 1 & & 200 & $\mu \mathrm{g} / \mathrm{L}$ \\
\hline Alkalinity & $\mathrm{GE}$ & JQ & 60.9 & & & $\mathrm{mg} / \mathrm{L}$ \\
\hline Aluminum & GE & & 5040 & & & $\mu g / L$ \\
\hline Americium-241 & GP & $\mathbf{U}$ & 1 & & 6.34 & $\mathrm{pCi} / \mathrm{L}$ \\
\hline Ammonia nitrogen & GE & & 0.1 & & & $\mathrm{mg} / \mathrm{L}$ \\
\hline Antimony & GE & $\mathbf{U}$ & 2 & & 5 & $\mu g / L$ \\
\hline Antimony-125 & GP & U & 20 & & 300 & $\mathrm{pCi} / \mathrm{L}$ \\
\hline Arsenic & GE & $\mathbf{U}$ & 2 & & 50 & $\mu g / L$ \\
\hline Barium & GE & & 24.5 & & 2000 & $\mu \mathrm{g} / \mathrm{L}$ \\
\hline Beryllium & GE & U & 3 & & 1 & $\mu g / L$ \\
\hline Cadmium & GE & $\mathbf{U}$ & 2 & & 5 & $\mu g / L$ \\
\hline Calcium & $\mathrm{GE}$ & & 1160 & & & $\mu g / L$ \\
\hline Carbon tetrachloride & GE & $\mathrm{U}$ & 1 & & 5 & $\mu \mathrm{g} / \mathrm{L}$ \\
\hline Cerium-144 & GP & $\mathbf{U}$ & 60 & & 261 & $\mathrm{pCi} / \mathrm{L}$ \\
\hline Cesium-134 & GP & $\mathbf{U}$ & 10 & & 81.3 & $\mathrm{pCi} / \mathrm{L}$ \\
\hline Cesium-137 & GP & & 31.2 & 6.3 & 200 & $\mathrm{pCi} / \mathrm{L}$ \\
\hline Chloride & GE & & 6.05 & & & $\mathrm{mg} / \mathrm{L}$ \\
\hline Chloroform & GE & U & 1 & & 100 & $\mu g / L$ \\
\hline Chromium & GE & $\mathbf{U}$ & 4 & & 100 & $\mu \mathrm{g} / \mathrm{L}$ \\
\hline Cobalt-57 & GP & $\mathrm{U}$ & 10 & & 1000 & $\mathrm{pCi} / \mathrm{L}$ \\
\hline Cobalt- 60 & GP & $\mathbf{U}$ & 10 & & 100 & $\mathrm{pCi} / L$ \\
\hline Copper & GE & & 7.37 & & 1300 & $\mu g / L$ \\
\hline Curium-242 & GP & $\mathrm{U}$ & 1 & & 0.133 & $\mathrm{pCi} / \Omega$ \\
\hline Curium-243,244 & GP & $\dot{U}$ & 1 & & 8.3 & $\mathrm{pCi} / \mathrm{L}$ \\
\hline Europium-152 & GP & $\mathbf{U}$ & 40 & & & $\mathrm{pCi} / \mathrm{L}$ \\
\hline Europium-154 & GP & $\mathbf{U}$ & 20 & & 200 & $\mathrm{pCi} / \Omega$ \\
\hline Europium-155 & GP & $\mathbf{U}$ & 30 & & 600 & $\mathrm{pCi} / \mathrm{L}$ \\
\hline Fluoride & GE & $\mathbf{U}$ & 0.1 & & 4 & $\mathrm{mg} / \mathrm{L}$ \\
\hline Gross alpha & $\mathrm{GE}$ & & 2 & 2.6 & 15 & $\mathrm{pCi} / \mathrm{L}$ \\
\hline Hardness & GE & & 2.8 & & & $\mathrm{mg} / \mathrm{L}$ \\
\hline Iodine-129 & $\mathrm{TE}$ & $\mathbf{U}$ & 2 & & 1 & $\mathrm{pCi} / \mathrm{L}$ \\
\hline Iron & GE & & 2810 & & 300 & $\mu \mathrm{g} / \mathrm{L}$ \\
\hline Lead & GE & & 6.565 & & 15 & $\mu g / L$ \\
\hline Magnesium & GE & & 492 & & & $\mu \mathrm{g} / \mathrm{L}$ \\
\hline Manganese & GE & & 206 & & 50 & $\mu g / L$ \\
\hline Manganese-54 & GP & $\mathbf{U}$ & 10 & & 300 & $\mathrm{pCi} / \mathrm{L}$ \\
\hline Mercury & GE & & 0.71 & & 2 & $\mu \mathrm{g} / \mathrm{L}$ \\
\hline Neptunium-237 & $\mathrm{TE}$ & $\mathbf{U}$ & 10 & & 7.06 & $\mathrm{pCi} / \mathrm{L}$ \\
\hline Nickel & GE & $\mathbf{U}$ & 4 & & 100 & $\mu g / L$ \\
\hline Nitrate as nitrogen & GE & & 2.8 & & 10 & $\mathrm{mg} / \mathrm{L}$ \\
\hline Nonvolatile beta & GE & & 49.7 & 4.7 & 50 & $\mathrm{pCi} / \mathrm{L}$ \\
\hline Plutonium-238 & GP & $\mathbf{U}$ & 1 & & 7.02 & $\mathrm{pCi} / \mathrm{L}$ \\
\hline Plutonium-239,240 & GP & $\mathbf{U}$ & 1 & & 62.1 & $\mathrm{pCi} / \mathrm{L}$ \\
\hline Potassium & GE & & 1110 & & & $\mu g / L$ \\
\hline Potassium-40 & GP & $\mathbf{U}$ & 110 & & 300 & $\mathrm{pCi} / \mathrm{L}$ \\
\hline Promethium-144 & GP & $\mathbf{U}$ & 10 & & & $\mathrm{pCi} / \mathrm{L}$ \\
\hline
\end{tabular}


(Table 29. Continued)

\begin{tabular}{|c|c|c|c|c|c|c|}
\hline Analyte & Lab & Mod & $\begin{array}{c}7 / 92 \\
\text { Result } \\
\end{array}$ & $A \propto c$ & Standard & Units \\
\hline Promethium-146 & GP & $\mathrm{U}$ & 10 & & & $\mathrm{pCi} / \mathrm{L}$ \\
\hline Radium-226 & GP & & 5.46 & 0.43 & 15.7 & $\mathrm{pCi} / \mathrm{L}$ \\
\hline Radium-228 & GP & & 153 & 3.6 & 7.85 & $\mathrm{pC} / / \mathrm{L}$ \\
\hline Ruthenium-106 & GP & $\mathbf{U}$ & 90 & & 30 & $\mathrm{pCi} / \mathrm{L}$ \\
\hline Selenium & GE & $\mathrm{U}$ & 2 & & 50 & $\mu \mathrm{g} / \mathrm{L}$ \\
\hline Silver & $\mathrm{GE}$ & $\mathrm{U}$ & 2 & & 50 & $\mu g / L$ \\
\hline Sodium & $\mathrm{GE}$ & & 40000 & & & $\mu g / L$ \\
\hline Sodium-22 & GP & $U$ & 10 & & 466 & $\mathrm{pCi} / \mathrm{L}$ \\
\hline Strontium-90 & GP & & 33.8 & 3.6 & 8 & $\mathrm{pCi} / \mathrm{L}$ \\
\hline Technetium-99 & GP & & 8640 & 140 & 900 & $\mathrm{pCi} / \mathrm{L}$ \\
\hline Tetrachloroethylene & GE & $\mathrm{U}$ & 1 & & 5 & $\mu \mathrm{g} / \mathrm{L}$ \\
\hline Thallium & GE & $\mathrm{U}$ & 2 & & 1 & $\mu g / L$ \\
\hline Thorium-228 & $\mathrm{GP}$ & U & 1 & & 125 & $\mathrm{pCi} / \mathrm{L}$ \\
\hline Thorium-230 & GP & U & 1 & & 79.2 & $\mathrm{pCi} / \mathrm{L}$ \\
\hline Thorium-232 & $G P$ & U & 1 & & 88 & $\mathrm{pCi} / \mathrm{L}$ \\
\hline Tin & GE & & 2.16 & & & $\mu g / L$ \\
\hline Total organic carbon & GE & JQ6 & 33.6 & & & $\mathrm{mg} / \mathrm{L}$ \\
\hline Total organic halogens & GE & & 32.5 & & & $\mu g / L$ \\
\hline Total phenols & GE & U & 5 & & & $\mu \mathrm{g} / \mathrm{L}$ \\
\hline Trichloroethylene & $\mathrm{GE}$ & U & 1 & & 5 & $\mu \mathrm{g} / \mathrm{L}$ \\
\hline Tritium & $\mathrm{GE}$ & & 3490 & 11 & 20 & $\mathrm{pCi} / \mathrm{ml}$ \\
\hline Uranium-234 & GP & $\mathrm{U}$ & 1 & & 13.9 & $\mathrm{pCi} / \mathrm{L}$ \\
\hline Uranium-235 & GP & U & 1 & & 14.5 & $\mathrm{pCi} / \mathrm{L}$ \\
\hline Uranium-238 & GP & $\mathbf{U}$ & 1 & & 14.6 & $\mathrm{pCi} / \mathrm{L}$ \\
\hline Vanadium & GE & & 11.7 & & & $\mu g / L$ \\
\hline Yttrium-88 & GP & $\mathrm{U}$ & 60 & & & $\mathrm{pCi} / \mathrm{L}$ \\
\hline Zinc & GE & & 153 & & & $\mu g / L$ \\
\hline Zinc-65 & GP & $\mathrm{U}$ & 20 & & 300 & $\mathrm{pCi} / L$ \\
\hline
\end{tabular}


Table 30. HSP092 Laboratory Analyses

Field Measurements:

Sample Date: 07/21/92

pH: 5.68

Specific Conductance: $33 \mu \mathrm{S} / \mathrm{cm}$

\begin{tabular}{|c|c|c|c|c|c|c|}
\hline Analyte & Lab & Mod & $\begin{array}{c}7 / 92 \\
\text { Result }\end{array}$ & $A \infty$ & Standard & Units \\
\hline 1,1,1-Trichloroethane & GE & $\mathbf{U}$ & 1 & & 200 & $\mu g / L$ \\
\hline Alkalinity & GE & v & 4.3 & & & $\mathrm{mg} / \mathrm{L}$ \\
\hline Aluminum & GE & & 648 & & & $\mu g / L$ \\
\hline Americium-241 & GP & $\mathbf{U}$ & 1 & & 6.34 & $\mathrm{pCi} / \mathrm{L}$ \\
\hline Ammonia nitrogen & GE & $\mathbf{U}$ & 0.1 & & & $\mathrm{mg} / \mathrm{L}$ \\
\hline Antimony & GE & $\mathbf{U}$ & 2 & & 5 & $\mu g / L$ \\
\hline Antimony-125 & GP & $\mathbf{U}$ & 20 & & 300 & $\mathrm{pCi} / L$ \\
\hline Arsenic & GE & $\mathbf{U}$ & 2 & & 50 & $\mu g / L$ \\
\hline Barium & $\mathrm{GE}$ & & 32.5 & & 2000 & $\mu g / L$ \\
\hline Beryllium & $\mathrm{GE}$ & $\mathbf{U}$ & 3 & & 1 & $\mu g / L$ \\
\hline Cadmium & GE & $\mathbf{U}$ & 2 & & 5 & $\mu g / L$ \\
\hline Calcium & $\mathrm{GE}$ & & 747 & & & $\mu g / L$ \\
\hline Carbon tetrachloride & $\mathrm{GE}$ & $\mathrm{U}$ & 1 & & 5 & $\mu g / L$ \\
\hline Cerium-144 & GP & $\mathrm{U}$ & 60 & & 261 & $\mathrm{pCi} / \mathrm{L}$ \\
\hline Cesium-134 & GP & U & 10 & & 81.3 & $\mathrm{pCi} / \mathrm{L}$ \\
\hline Cesium-137 & GP & $\mathrm{U}$ & 10 & & 200 & $\mathrm{pCi} / \mathrm{L}$ \\
\hline Chloride & $\mathrm{GE}$ & & 3.93 & & & $\mathrm{mg} / \mathrm{L}$ \\
\hline Chloroform & $\mathrm{GE}$ & U & 1 & & 100 & $\mu g / L$ \\
\hline Chromium & $G E$ & $\mathbf{U}$ & 4 & & 100 & $\mu g / \mathrm{h}$ \\
\hline Cobalt-57 & $G P$ & $\mathrm{U}$ & 10 & & 1000 & $\mathrm{pCi} / \mathrm{L}$ \\
\hline Cobalt- 60 & GP & $\mathbf{U}$ & 10 & & 100 & $\mathrm{pCi} / \mathrm{L}$ \\
\hline Copper & $\mathrm{GE}$ & $\mathbf{U}$ & 4 & & 1300 & $\mu g / L$ \\
\hline Curium-242 & GP & $\mathrm{U}$ & 1 & & 0.133 & $\mathrm{pCi} / \mathrm{L}$ \\
\hline Curium-243,244 & GP & $\mathbf{U}$ & 1 & & 8.3 & $\mathrm{pCi} / \mathrm{L}$ \\
\hline Europium-152 & GP & $\mathrm{U}$ & 40 & & & $\mathrm{pCi} / \mathrm{L}$ \\
\hline Europium-154 & GP & $\mathrm{U}$ & 20 & & 200 & $\mathrm{pCi} / \mathrm{L}$ \\
\hline Europium-155 & GP & U & 30 & & 600 & $\mathrm{pCi} / \mathrm{L}$ \\
\hline Fluoride & GE & & 0.127 & & 4 & $\mathrm{mg} / \mathrm{L}$ \\
\hline Gross alpha & $\mathrm{GE}$ & U & 2 & & 15 & $\mathrm{pCi} / \mathrm{L}$ \\
\hline Hardness & GE & & 2.8 & & & $\mathrm{mg} / \mathrm{L}$ \\
\hline Iodine-129 & $\mathrm{TE}$ & U & 2 & & 1 & $\mathrm{pCi} / \mathrm{L}$ \\
\hline Iron & GE & & 2880 & & 300 & $\mu \mathrm{g} / \mathrm{L}$ \\
\hline Lead & $\mathrm{GE}$ & $\mathrm{U}$ & 3 & & 15 & $\mu \mathrm{g} / \mathrm{L}$ \\
\hline Magnesium & GE & & 762 & & & $\mu g / L$ \\
\hline Manganese & $\mathrm{GE}$ & & 207 & & 50 & $\mu \mathrm{g} / \mathrm{L}$ \\
\hline Manganese-54 & GP & $\mathrm{U}$ & 10 & & 300 & $\mathrm{pCi} / \mathrm{L}$ \\
\hline Mercury & GE & & 0.22 & & 2 & $\mu g / L$ \\
\hline Neptunium-237 & TE & $\mathbf{U}$ & 10 & & & $\mathrm{pCi} / \mathrm{L}$ \\
\hline Nickel & $\mathrm{GE}$ & $\mathbf{U}$ & 4 & & 100 & $\mu g / L$ \\
\hline Nitrate as nitrogen & GE & $\mathrm{U}$ & 0.05 & & 10 & $\mathrm{mg} / \mathrm{L}$ \\
\hline Nonvolatile beta & GE & $\mathrm{V}$ & 3 & 1.5 & 50 & $\mathrm{pCi} / \mathrm{L}$ \\
\hline Plutonium-238 & GP & $\mathbf{U}$ & 1 & & 7.02 & $\mathrm{pCi} / \mathrm{L}$ \\
\hline Plutonium-239,240 & GP & U & 1 & & 62.1 & $\mathrm{pCi} / \mathrm{L}$ \\
\hline Potassium & GE & $\mathrm{U}$ & 500 & & & $\mu g / L$ \\
\hline Potassium -40 & GP & $\mathbf{U}$ & 110 & & 300 & $\mathrm{pCi} / \mathrm{L}$ \\
\hline Promethium-144 & GP & $\mathrm{U}$ & 10 & & & $\mathrm{pCi} / \mathrm{L}$ \\
\hline
\end{tabular}


(Table 30. Continued)

\begin{tabular}{|c|c|c|c|c|c|c|}
\hline \multirow[b]{2}{*}{ Analyte } & \multicolumn{5}{|c|}{$7 / 92$} & \multirow[b]{2}{*}{ Units } \\
\hline & Lab & Mod & Result & Acc & Standard & \\
\hline Promethium-146 & GP & $\mathbf{U}$ & 10 & & & $\mathrm{pCi} / \mathrm{L}$ \\
\hline Radium-226 & GP & & 1.595 & 0.27 & 15.7 & $\mathrm{pCi} / \mathrm{L}$ \\
\hline Radium-228 & GP & & 1.75 & 0.72 & 7.85 & $\mathrm{pCi} / \mathrm{L}$ \\
\hline Ruthenium-106 & GP & $U$ & 90 & & 30 & $\mathrm{pCi} / \Omega$ \\
\hline Selenium & GE & UI1 & 2 & & 50 & $\mu g / L$ \\
\hline Silver & GE & $\mathbf{U}$ & 2 & & 50 & $\mu g / L$ \\
\hline Sodium & GE & & 2850 & & & $\mu g / L$ \\
\hline Sodium-22 & GP & $\mathbf{U}$ & 10 & & 466 & $\mathrm{pCi} / L$ \\
\hline Strontium-90 & GP & & 6.79 & 1.5 & 8 & $\mathrm{pCi} / \mathrm{L}$ \\
\hline Technetium-99 & GP & & 696 & 44 & 900 & $\mathrm{pCi} / \mathrm{L}$ \\
\hline Tetrachloroethylene & GE & $\mathrm{U}$ & 1 & & 5 & $\mu g / L$ \\
\hline Thallium & GE & $\mathbf{U}$ & 2 & & 1 & $\mu g / L$ \\
\hline Thorium-228 & GP & $\mathrm{U}$ & 1 & & 125 & $\mathrm{pCi} / \mathrm{L}$ \\
\hline Thorium-230 & GP & $\mathbf{U}$ & 1 & & 79.2 & $\mathrm{pCi} / \mathrm{L}$ \\
\hline Thorium-232 & GP & $U$ & 1 & & 88 & $\mathrm{pCi} / \mathrm{L}$ \\
\hline Tin & GE & $\mathbf{U}$ & 2 & & & $\mu \mathrm{g} / \mathrm{L}$ \\
\hline Total organic carbon & GE & & 7.93 & & & $\mathrm{mg} / \mathrm{L}$ \\
\hline Total organic halogens & GE & $\mathrm{U}$ & 5 & & & $\mu g / L$ \\
\hline Total phenols & GE & $\mathrm{U}$ & 5 & & & $\mu g / L$ \\
\hline Trichloroethylene & GE & $\mathrm{U}$ & 1 & & 5 & $\mu g / L$ \\
\hline Tritium & GE & & 305.5 & 2.8 & 20 & $\mathrm{pCi} / \mathrm{ml}$ \\
\hline Uranium-234 & GP & $\mathrm{U}$ & 1 & & 13.9 & $\mathrm{pCi} / \mathrm{L}$ \\
\hline Uranium-235 & GP & $\mathrm{U}$ & 1 & & & $\mathrm{pCi} / \mathrm{L}$ \\
\hline Uranium-238 & GP & U & 1 & & 14.6 & $\mathrm{pCi} / \mathrm{L}$ \\
\hline Vanadium & GE & $\mathrm{U}$ & 8 & & & $\mu \mathrm{g} / \mathrm{L}$ \\
\hline Yttrium-88 & GP & $U$ & 60 & & & $\mathrm{pCi} / \mathrm{L}$ \\
\hline Zinc & GE & & 195 & & & $\mu g / L$ \\
\hline Zinc-65 & GP & U & 20 & & 300 & $\mathrm{pCi} / \mathrm{L}$ \\
\hline
\end{tabular}


Table 31. QA 2S Laboratory Analyses

Field Measurements: Trip blank Sample Date: NA

$\mathrm{pH}: \mathrm{NA}$

Specific Conductance: NA

\begin{tabular}{|c|c|c|c|c|c|c|}
\hline Analyte & Lab & Mod & Result & $A \propto$ & Standard & Units \\
\hline 1,1,1-Trichloroethane & $\overline{G E}$ & $\mathrm{JQ}$ & 25.4 & & 200 & $\mu g / L$ \\
\hline Alkalinity & $G E$ & $\mathrm{JQ}$ & 8.36 & & & $\mathrm{mg} / \mathrm{L}$ \\
\hline Aluminum & GE & $\mathrm{U}$ & 20 & & & $\mu g / L$ \\
\hline Americium-241 & GP & $\mathbf{U}$ & 1 & & 6.34 & $\mathrm{PCi} / \mathrm{L}$ \\
\hline Ammonia nitrogen & GE & $\mathrm{U}$ & 0.1 & & & $\mathrm{mg} / \mathrm{L}$ \\
\hline Antimony & GE & $\mathbf{U}$ & 2 & & 5 & $\mu g / L$ \\
\hline Antimony-125 & GP & $\mathrm{U}$ & 20 & & 5 & $\mathrm{pCi} / \mathrm{L}$ \\
\hline Arsenic & GE & $\mathrm{U}$ & 2 & & 50 & $\mu g / L$ \\
\hline Barium & GE & $\mathrm{U}$ & 3 & & 2000 & $\mu g / L$ \\
\hline Beryllium & GE & $\mathrm{U}$ & 3 & & 1 & $\mu g / L$ \\
\hline Cadmium & GE & $\mathrm{U}$ & 2 & & 5 & $\mu g / L$ \\
\hline Calcium & GE & $\mathrm{U}$ & 10 & & & $\mu g / L$ \\
\hline Carbon tetrachloride & GE & JQU & 1 & & 5 & $\mu g / L$ \\
\hline Cerium-144 & GP & $\mathrm{U}$ & 60 & & 261 & $\mathrm{pCi} / \mathrm{L}$ \\
\hline Chloride & GE & & 6.4 & & & $\mathrm{mg} / \mathrm{L}$ \\
\hline Chloroform & $\mathrm{GE}$ & JQU & 1 & & 100 & $\mu g / L$ \\
\hline Chromium & GE & $\mathbf{U}$ & 4 & & 100 & $\mu g / L$ \\
\hline Cobalt-57 & GP & $\mathbf{U}$ & 10 & & 1000 & $\mathrm{pCi} / \mathrm{L}$ \\
\hline Cobalt-60 & GP & $\mathrm{U}$ & 10 & & 100 & $\mathrm{pCi} / \mathrm{L}$ \\
\hline Copper & GE & $\mathbf{U}$ & 4 & & 1300 & $\mu \mathrm{g} / \mathrm{L}$ \\
\hline Curium-242 & GP & $\mathbf{U}$ & $\cdot 1$ & & 0.133 & $\mathrm{pCi} / \mathrm{L}$ \\
\hline Curium-243,244 & GP & $\mathrm{U}$ & 1 & & 8.3 & $\mathrm{pCi} / \mathrm{L}$ \\
\hline Europium-152 & $G P$ & $\mathrm{U}$ & 40 & & & $\mathrm{pCi} / \Omega$ \\
\hline Europium-154 & GP & $\mathbf{U}$ & 20 & & 200 & $\mathrm{pCi} / \mathrm{L}$ \\
\hline Europium-155 & GP & $\mathrm{U}$ & 30 & & 600 & $\mathrm{pCi} / \mathrm{L}$ \\
\hline Fluoride & GE & $U$ & 0.1 & & 4 & $\mathrm{mg} / \mathrm{L}$ \\
\hline Gross Alpha & $\mathrm{GE}$ & $\mathrm{U}$ & 2 & & 15 & $\mathrm{pCi} / \Omega$ \\
\hline Hardness & $\mathrm{GE}$ & & 7.5 & & & $\mathrm{mg} / \mathrm{L}$ \\
\hline Iodine-129 & $\mathrm{TE}$ & U & 2 & & 1 & $\mathrm{pCi} / \mathrm{L}$ \\
\hline Iron & $\mathrm{GE}$ & UI1 & 4 & & 300 & $\mu \mathrm{g} / \mathrm{L}$ \\
\hline Lead & $\mathrm{GE}$ & $\mathrm{U}$ & 3 & & 15 & $\mu g / L$ \\
\hline Magnesium & GE & $\mathbf{U}$ & 2 & & & $\mu g / L$ \\
\hline Manganese & $\mathrm{GE}$ & $\mathrm{U}$ & 2 & & 50 & $\mu g / L$ \\
\hline Manganese-54 & GP & $\mathrm{U}$ & 10 & & 50 & $\mathrm{pCi} / \mathrm{L}$ \\
\hline Mercury & GE & U & 0.2 & & 2 & $\mu g / L$ \\
\hline Neptunium-237 & $\mathrm{TE}$ & $\mathrm{U}$ & 10 & & & $\mathrm{pCi} / \mathrm{L}$ \\
\hline Nickel & $G E$ & & 8.65 & & 100 & $\mu g / L$ \\
\hline Nitrate as nitrogen & $\mathrm{GE}$ & $\mathrm{U}$ & 0.05 & & 10 & $\mathrm{mg} / \mathrm{L}$ \\
\hline Nonvolatile beta & GE & $\mathrm{U}$ & 2 & & 50 & $\mathrm{pCi} / \mathrm{L}$ \\
\hline Plutonium-238 & GP & $\mathrm{U}$ & 1 & & 7.02 & $\mathrm{pCi} / \mathrm{L}$ \\
\hline Plutonium-239,240 & GP & $\mathrm{U}$ & 1 & & 62.1 & $\mathrm{pCi} / \mathrm{L}$ \\
\hline Potassium & $\mathrm{GE}$ & & 777 & & & $\mu g / L$ \\
\hline Potassium-40 & GP & $\mathbf{U}$ & 110 & & 300 & $\mathrm{pCi} / \mathrm{L}$ \\
\hline Promethium-144 & GP & $\mathrm{U}$ & 10 & & & $\mathrm{pCi} / \mathrm{L}$ \\
\hline Promethium-146 & GP & $\mathrm{U}$ & 10 & & & $\mathrm{pCi} / \mathrm{L}$ \\
\hline Radium-226 & GP & & 1.1 & 0.15 & & $\mathrm{pCi} / \mathrm{L}$ \\
\hline Radium-228 & GP & $\mathrm{U}$ & 1 & & 7.85 & $\mathrm{pCi} / \mathrm{L}$ \\
\hline
\end{tabular}


(Table 31. Continued)

\begin{tabular}{|c|c|c|c|c|c|c|}
\hline Analyte & Lab & Mod & Result & Acc & Standard & Units \\
\hline Ruthenium-106 & GP & $\bar{U}$ & 90 & & 30 & $\mathrm{pCi} / \mathrm{L}$ \\
\hline Selenium & $\mathrm{GE}$ & UII & 2 & & 50 & $\mu g / L$ \\
\hline Silver & GE & $\mathrm{U}$ & 2 & & 50 & $\mu g / L$ \\
\hline Sodium & GE & & 11400 & & & $\mu g / L$ \\
\hline Sodium & GP & $\mathbf{U}$ & 10 & & & $\mathrm{pCi} / \mathrm{L}$ \\
\hline Cesium-134 & GP & $\mathrm{U}$ & 10 & & 81.3 & $\mathrm{pCi} / \mathrm{L}$ \\
\hline Cesium-137 & GP & $\mathbf{U}$ & 10 & & 200 & $\mathrm{pCi} / \mathrm{L}$ \\
\hline Strontium-90 & GP & $\mathrm{U}$ & 2 & & 8 & $\mathrm{pCi} / \mathrm{L}$ \\
\hline Technetium-99 & GP & $\mathbf{U}$ & 300 & & 900 & $\mathrm{pCi} / \mathrm{L}$ \\
\hline Thallium & GE & $\mathbf{U}$ & 2 & & 1 & $\mu g / L$ \\
\hline Thorium-228 & GP & U & 1 & & 125 & $\mathrm{pCi} / \mathrm{L}$ \\
\hline Thorium-230 & GP & U & 1 & & 79.2 & $\mathrm{pCi} / \Omega$ \\
\hline Thorium-232 & GP & $\mathbf{U}$ & 1 & & & $\mathrm{pCi} / \mathrm{L}$ \\
\hline Tin & GE & & 4.81 & & & $\mu g / L$ \\
\hline Total organic carbon & GE & JQU & 1 & & & $\mathrm{mg} / \mathrm{L}$ \\
\hline Total organic halogens & GE & JQU & 5 & & & $\mu g / L$ \\
\hline Total phenols & GE & $\mathbf{U}$ & 5 & & & $\mu g / L$ \\
\hline Trichloroethylene & GE & JQU & 1 & & 5 & $\mu g / L$ \\
\hline Tetrachloroethylene & GE & JQU & 1 & & 5 & $\mu \mathrm{g} / \mathrm{L}$ \\
\hline Tritium & GE & $\mathrm{U}$ & 0.7 & & 20 & $\mathrm{pCi} / \mathrm{ml}$ \\
\hline Uranium-234 & GP & $\mathrm{U}$ & 1 & & 13.9 & $\mathrm{pCi} / \mathrm{L}$ \\
\hline Uranium-235 & GP & $\mathrm{U}$ & 1 & & & $\mathrm{pCi} / \Omega$ \\
\hline Uranium-238 & GP & $\mathrm{U}$ & 1 & & 14.6 & $\mathrm{pCi} / \mathrm{L}$ \\
\hline Vanadium & $G E$ & $\mathrm{U}$ & 8 & & & $\mu g / L$ \\
\hline Yttrium-88 & GP & $\mathbf{U}$ & 60 & & & $\mathrm{pCi} / \mathrm{L}$ \\
\hline Zinc & GE & $\mathbf{U}$ & 2 & & & $\mu g / L$ \\
\hline Zinc-65 & GP & $\mathbf{U}$ & 20 & & 300 & $\mathrm{pCi} / \mathrm{L}$ \\
\hline
\end{tabular}




\section{Table 32. QA4S Laboratory Analyses}

Field Measurements: Trip blank

Sample Date: NA

pH: NA

Specific Conductance: NA

\begin{tabular}{|c|c|c|c|c|c|c|}
\hline Analyte & Lab & Mod & $\begin{array}{c}7 / 92 \\
\text { Result }\end{array}$ & Acc & Standard & Units \\
\hline 1,1,1-Trichloroethane & GE & $\mathrm{U}$ & 1 & & 200 & $\mu g / L$ \\
\hline Alkalinity & GE & $\mathbf{V}$ & 11.9 & & & $\mathrm{mg} / \mathrm{L}$ \\
\hline Aluminum & $\mathrm{GE}$ & $\mathbf{U}$ & 20 & & & $\mu g / L$ \\
\hline Americium-241 & GP & $\mathbf{U}$ & 1 & & 6.34 & $\mathrm{pCi} / 2$ \\
\hline Ammonia nitrogen & GE & $\mathbf{U}$ & 0.1 & & & $\mathrm{mg} / \mathrm{L}$ \\
\hline Antimony & GE & $\mathrm{U}$ & 2 & & 5 & $\mu g / L$ \\
\hline Antimony-125 & GP & U & 20 & & & $\mathrm{pCi} / \mathrm{L}$ \\
\hline Arsenic & $\mathrm{GE}$ & U & 2 & & 50 & $\mu g / L$ \\
\hline Barium & GE & $\mathbf{U}$ & 3 & & 2000 & $\mu \mathrm{g} / \mathrm{L}$ \\
\hline Beryllium & GE & $\mathbf{U}$ & 3 & & 1 & $\mu g / L$ \\
\hline Cadmium & $G E$ & $\mathrm{U}$ & 2 & & 5 & $\mu g / L$ \\
\hline Calcium & GE & $\mathbf{U}$ & 10 & & & $\mu g / L$ \\
\hline Carbon tetrachloride & GE & $\mathrm{U}$ & 1 & & 5 & $\mu \mathrm{g} / \mathrm{L}$ \\
\hline Cerium-144 & GP & U & 60 & & 261 & $\mathrm{pCi} / \mathrm{L}$ \\
\hline Cesium-134 & GP & $\mathbf{U}$ & 10 & & 81.3 & $\mathrm{pCi} / \mathrm{L}$ \\
\hline Cesium-137 & $G P$ & U & 10 & & 200 & $\mathrm{pCi} / \mathrm{L}$ \\
\hline Chloride & GE & & 10.3 & & & $\mathrm{mg} / \mathrm{L}$ \\
\hline Chloroform & GE & $\mathrm{U}$ & 1 & & 100 & $\mu g / L$ \\
\hline Chromium & GE & U & 4 & & 100 & $\mu g / L$ \\
\hline Cobalt-57 & GP & $\mathrm{U}$ & 10 & & 1000 & $\mathrm{pCi} / \mathrm{L}$ \\
\hline Cobalt-60 & $G P$ & $\mathrm{U}$ & 10 & & 100 & $\mathrm{pCi} / \mathrm{L}$ \\
\hline Copper & $\mathrm{GE}$ & $\mathrm{U}$ & 4 & & 1300 & $\mu g / L$ \\
\hline Curium-242 & GP & $\mathbf{U}$ & 1 & & 0.133 & $\mathrm{pCi} / \mathrm{L}$ \\
\hline Curium-243,244 & $G P$ & $U$ & 1 & & 8.3 & $\mathrm{pCi} / \mathrm{L}$ \\
\hline Europium-152 & GP & $\mathrm{U}$ & 40 & & & $\mathrm{pCi} / \mathrm{L}$ \\
\hline Europium-154 & GP & $\mathbf{U}$ & 20 & & 200 & $\mathrm{pCi} / \mathrm{L}$ \\
\hline Europium-155 & $G P$ & $U$ & 30 & & 600 & $\mathrm{pCi} / \mathrm{L}$ \\
\hline Fluoride & $\mathrm{GE}$ & $\mathrm{U}$ & 0.1 & & 4 & $\mathrm{mg} / \mathrm{L}$ \\
\hline Gross alpha & $\mathrm{GE}$ & $\mathrm{U}$ & 2 & & 15 & $\mathrm{pCi} / \mathrm{L}$ \\
\hline Hardness & $\mathrm{GE}$ & & 3 & & & $\mathrm{mg} / \mathrm{L}$ \\
\hline Iodine-129 & TE & $U$ & 2 & & 1 & $\mathrm{pCi} / \mathrm{L}$ \\
\hline Iron & $\mathrm{GE}$ & $\mathbf{U}$ & 4 & & 300 & $\mu g / L$ \\
\hline Lead & $\mathrm{GE}$ & $\mathrm{U}$ & 3 & & 15 & $\mu g / L$ \\
\hline Magnesium & $\mathrm{GE}$ & $\mathrm{U}$ & 2 & & & $\mu g / L$ \\
\hline Manganese & GE & U & 2 & & 50 & $\mu g / L$ \\
\hline Manganese- 54 & GP & $\mathrm{U}$ & 10 & & & $\mathrm{pCi} / \mathrm{L}$ \\
\hline Mercury & GE & $\mathrm{U}$ & 0.2 & & 2 & $\mu g / L$ \\
\hline Neptunium-237 & $\mathrm{TE}$ & $U$ & 10 & & & $\mathrm{pCi} / \mathrm{L}$ \\
\hline Nickel & $\mathrm{GE}$ & $\mathbf{U}$ & 4 & & 100 & $\mu g / L$ \\
\hline Nitrate as nitrogen & $\mathrm{GE}$ & $\mathrm{U}$ & 0.05 & & 10 & $\mathrm{mg} / \mathrm{L}$ \\
\hline Nonvolatile beta & GE & $\mathrm{U}$ & 2 & & & $\mathrm{pCi} / \mathrm{L}$ \\
\hline Plutonium-238 & GP & $\mathrm{U}$ & 1 & & 7.02 & $\mathrm{pCi} / \mathrm{L}$ \\
\hline Plutonium-239,240 & GP & $\mathbf{U}$ & 1 & & 62.1 & $\mathrm{pCi} / \mathrm{L}$ \\
\hline Potassium & $\mathrm{GE}$ & & 715 & & & $\mu \mathrm{g} / \mathrm{L}$ \\
\hline Potassium-40 & GP & $\mathrm{U}$ & 110 & & 300 & $\mathrm{pCi} / \mathrm{L}$ \\
\hline Promethium-144 & GP & $\mathrm{U}$ & 10 & & & $\mathrm{pCi} / \mathrm{L}$ \\
\hline
\end{tabular}


(Table 32. Continued)

\begin{tabular}{|c|c|c|c|c|c|c|}
\hline Analyte & Lab & Mod & $\begin{array}{c}7 / 92 \\
\text { Result }\end{array}$ & $A \propto c$ & Standard & Units \\
\hline Promethium-146 & GP & $\mathrm{U}$ & 10 & & & $\overline{\mathrm{pCi} / \mathrm{L}}$ \\
\hline Radium-226 & GP & $\mathrm{U}$ & 1 & & & $\mathrm{pCi} / \mathrm{L}$ \\
\hline Radium-228 & GP & & 1.145 & 0.8 & 7.85 & $\mathrm{pCi} / \mathrm{L}$ \\
\hline Rutbenium-106 & GP & $\mathrm{U}$ & 90 & & 30 & $\mathrm{pCi} / \mathrm{L}$ \\
\hline Selenium & $\mathrm{GE}$ & U & 2 & & 50 & $\mu \mathrm{g} / \mathrm{L}$ \\
\hline Silver & GE & $\mathrm{U}$ & 2 & & 50 & $\mu g / L$ \\
\hline Sodium & GE & & 11200 & & & $\mu g / L$ \\
\hline Sodium-22 & GP & U & 10 & & & $\mathrm{pC} \mathrm{i} / \mathrm{L}$ \\
\hline Strontium-90 & GP & U & 2 & & 8 & $\mathrm{pCi} / \mathrm{L}$ \\
\hline Technetium-99 & GP & $\mathbf{U}$ & 300 & & 900 & $\mathrm{pCi} / \mathrm{L}$ \\
\hline Thallium & GE & $\mathbf{U}$ & 2 & & 1 & $\mu g / L$ \\
\hline Thorium-228 & GP & $\mathbf{U}$ & 1 & & 125 & $\mathrm{pCi} / \mathrm{L}$ \\
\hline Thorium-230 & GP & U & 1 & & 79.2 & $\mathrm{pC} \mathrm{Ci} / \mathrm{L}$ \\
\hline Thorium-232 & GP & U & 1 & & & $\mathrm{pCi} / \mathrm{L}$ \\
\hline Tin & $\mathrm{GE}$ & $\mathrm{U}$ & 2 & & & $\mu g / L$ \\
\hline Total organic carbon & $\mathrm{GE}$ & $\mathrm{U}$ & 1 & & & $\mathrm{mg} / \mathrm{L}$ \\
\hline Total organic halogens & GE & $\mathrm{U}$ & 5 & & & $\mu g / L$ \\
\hline Total phenols & GE & $\mathrm{U}$ & 5 & & & $\mu g / L$ \\
\hline Trichloroethylene & GE & $\mathrm{U}$ & 1 & & 5 & $\mu g / L$ \\
\hline Tetrachloroethylene & GE & $\mathrm{U}$ & 1 & & 5 & $\mu g / L$ \\
\hline Tritium & GE & $\mathrm{U}$ & 0.7 & & 20 & $\mathrm{pCi} / \mathrm{ml}$ \\
\hline Uranium-234 & GP & $\mathrm{U}$ & 1 & & 13.9 & $\mathrm{pCi} / \mathrm{L}$ \\
\hline Uranium-235 & GP & $\mathrm{U}$ & 1 & & & $\mathrm{pCi} / \mathrm{L}$ \\
\hline Uranium-238 & GP & $U$ & 1 & & 14.6 & $\mathrm{pCi} / \mathrm{L}$ \\
\hline Vanadium & GE & $\mathbf{U}$ & 8 & & & $\mu \mathrm{g} / \mathrm{L}$ \\
\hline Yttrium-88 & GP & $\mathbf{U}$ & 60 & & & $\mathrm{pCi} / \mathrm{L}$ \\
\hline Zinc & GE & $\mathrm{U}$ & 2 & & & $\mu g / L$ \\
\hline Zinc-65 & GP & $\mathbf{U}$ & 20 & & 300 & $\mathrm{pCi} / \mathrm{L}$ \\
\hline
\end{tabular}


Table 33. QA1 Laboratory Analyses

Collected from deionized water source used in all field activities (except trip blanks).

Field Measurements:

Sample Date: 07/27/92

$\mathrm{pH}: \mathrm{NA}$

Specific Conductance: NA

\begin{tabular}{|c|c|c|c|c|c|}
\hline Analyte & Lab & Mod & $\begin{array}{c}7 / 92 \\
\text { Result }\end{array}$ & Acc & Units \\
\hline Aluminum & $\mathrm{GE}$ & & 22.4 & & $\mu g / L$ \\
\hline Americium-241 & $\mathrm{GE}$ & $\mathbf{U}$ & 1 & & $\mathrm{pCi} / \mathrm{L}$ \\
\hline Ammonia Nitrogen & $\mathrm{GE}$ & U & 0.1 & & $\mathrm{mg} / \mathrm{L}$ \\
\hline Antimony & $\mathrm{GE}$ & U & 2 & & $\mu g / L$ \\
\hline Antimony-125 & $\mathrm{GE}$ & $\mathbf{U}$ & 20 & & $\mathrm{pCi} / \mathrm{L}$ \\
\hline Arsenic & $\mathrm{GE}$ & $\mathbf{U}$ & 2 & & $\mu g / L$ \\
\hline Barium & GE & $\mathrm{U}$ & 3 & & $\mu g / L$ \\
\hline Beryllium & GE & U & 3 & & $\mu g / L$ \\
\hline Cadmium & $G E$ & $\mathbf{U}$ & 2 & & $\mu g / L$ \\
\hline Calcium & $\mathrm{GE}$ & & 15.7 & & $\mu \mathrm{g} / \mathrm{L}$ \\
\hline Cerium-144 & GE & $\mathrm{U}$ & 60 & & $\mathrm{pCi} / L$ \\
\hline Cesium-134 & GE & $\mathbf{U}$ & 10 & & $\mathrm{pCi} / \mathrm{L}$ \\
\hline Cesium137 & $\overline{G E}$ & U & 10 & & $\mathrm{pCi} / \mathrm{L}$ \\
\hline Chloride & GE & $\mathrm{U}$ & 0.25 & & $\mathrm{mg} / \mathrm{L}$ \\
\hline Chromium & GE & $\mathbf{U}$ & 4 & & $\mu g / L$ \\
\hline Cobalt-57 & $\mathrm{GE}$ & $\mathbf{U}$ & 10 & & $\mathrm{pCi} / \mathrm{L}$ \\
\hline Cobalt -60 & $\mathrm{GE}$ & $\mathrm{U}$ & 10 & & $\mathrm{pCi} / \mathrm{L}$ \\
\hline Copper & GE & $\mathbf{U}$ & 4 & & $\mu g / L$ \\
\hline Curium-242 & $\mathrm{GE}$ & $\mathbf{U}$ & 1 & & $\mathrm{pCi} / \mathrm{L}$ \\
\hline Curium-243,244 & $\mathrm{GE}$ & $\mathbf{U}$ & 1 & & $\mathrm{pCi} / \mathrm{L}$ \\
\hline Europium-152 & $\mathrm{GE}$ & $\mathbf{U}$ & 40 & & $\mathrm{pCi} / \mathrm{L}$ \\
\hline Europium-154 & $\mathrm{GE}$ & $\mathrm{U}$ & 20 & & $\mathrm{pCi} / \mathrm{L}$ \\
\hline Europium-155 & GE & U & 30 & & $\mathrm{pC} / \mathrm{i} / \mathrm{L}$ \\
\hline Fluoride & GE & $\mathbf{U}$ & 0.1 & & $\mathrm{mg} / \mathrm{L}$ \\
\hline Hardness & $\mathbf{G E}$ & $\mathbf{U}$ & 1 & & $\mathrm{mg} / \mathrm{L}$ \\
\hline Iodine-129 & $\mathrm{TE}$ & $\mathbf{U}$ & 2 & & $\mathrm{pCi} / \mathrm{L}$ \\
\hline Iron & GE & & 21.7 & & $\mu \mathrm{g} / \mathrm{L}$ \\
\hline Lead & GE & $\mathrm{U}$ & 3 & & $\mu g / L$ \\
\hline Magnesium & GE & & 3.55 & & $\mu g / L$ \\
\hline Manganese & $\mathrm{GE}$ & $\mathrm{U}$ & 2 & & $\mu g / L$ \\
\hline Manganese-54 & GE & U & 10 & & $\mathrm{pCi} / \mathrm{L}$ \\
\hline Mercury & GE & U & 0.2 & & $\mu \mathrm{g} / \mathrm{L}$ \\
\hline Neptunium-237 & $\mathrm{TE}$ & $\mathrm{U}$ & 10 & & $\mathrm{pCi} / \mathrm{L}$ \\
\hline Nickel & $\mathrm{GE}$ & $\mathbf{U}$ & 0.05 & & $\mathrm{mg} / \mathrm{L}$ \\
\hline Nickel & $\mathrm{GE}$ & $\mathrm{U}$ & 4 & & $\mu g / L$ \\
\hline Plutonium-238 & $\mathrm{GE}$ & $\mathrm{U}$ & 1 & & $\mathrm{pCi} / \mathrm{L}$ \\
\hline Plutonium-239,240 & $\mathrm{GE}$ & $\mathbf{U}$ & 1 & & $\mathrm{pCi} / \mathrm{L}$ \\
\hline Potassium & $\mathrm{GE}$ & $\mathbf{U}$ & 500 & & $\mu g / L$ \\
\hline Potassium-40 & $\mathrm{GE}$ & $\mathbf{U}$ & 110 & & $\mathrm{pCi} / \mathrm{L}$ \\
\hline Promethium-144 & GE & $\mathbf{U}$ & 10 & & $\mathrm{pCi} / \mathrm{L}$ \\
\hline Promethium-146 & GE & $\mathrm{U}$ & 10 & & $\mathrm{pCi} / \mathrm{L}$ \\
\hline Radium-226 & $\mathrm{GE}$ & $\mathbf{U}$ & 1 & & $\mathrm{pCi} / \mathrm{L}$ \\
\hline
\end{tabular}


(Table 33. Continued)

\begin{tabular}{|c|c|c|c|c|c|}
\hline \multirow[b]{2}{*}{ Analyte } & \multicolumn{5}{|c|}{$7 / 92$} \\
\hline & Lab & Mod & Result & Acc & Units \\
\hline Radium-228 & $\mathrm{TE}$ & $\mathrm{U}$ & 1 & & $\mathrm{pCi} / \mathrm{L}$ \\
\hline Ruthenium-106 & GE & $\mathbf{U}$ & 90 & & $\mathrm{pCi} / \mathrm{L}$ \\
\hline Selenium & GE & $\mathbf{U}$ & 2 & & $\mu g / L$ \\
\hline Silver & GE & U & 2 & & $\mu g / L$ \\
\hline Sodium & GE & & 27.2 & & $\mu \mathrm{g} / \mathrm{L}$ \\
\hline Sodium-22 & GE & $\mathbf{U}$ & 10 & & $\mathrm{pCi} / \mathrm{L}$ \\
\hline Strontium-90 & GE & $\mathbf{U}$ & 2 & & $\mathrm{pCi} / \mathrm{L}$ \\
\hline Technetium-99 & GE & $\mathrm{U}$ & 300 & & $\mathrm{pCi} / \mathrm{L}$ \\
\hline Tetrachloroethylene & GE & $\mathbf{U}$ & 1 & & $\mu \mathrm{g} / \mathrm{L}$ \\
\hline Thallium & GE & $\mathbf{U}$ & 2 & & $\mu \mathrm{g} / \mathrm{L}$ \\
\hline Thallium-228 & GE & $\mathrm{U}$ & 1 & & $\mathrm{pCi} / \mathrm{L}$ \\
\hline Thallium-230 & GE & $\mathbf{U}$ & 1 & & $\mathrm{pCi} / \mathrm{L}$ \\
\hline Thallium-232 & GE & $\mathbf{U}$ & 1 & & $\mathrm{pCi} / \mathrm{L}$ \\
\hline Tin & GE & $\mathrm{U}$ & 2 & & $\mu g / L$ \\
\hline Total organic carbon & GE & $\mathrm{U}$ & 1 & & $\mathrm{mg} / \mathrm{L}$ \\
\hline Total organic halogens & GE & $\mathrm{U}$ & 5 & & $\mu g / L$ \\
\hline Total phenols & $\mathrm{GE}$ & & 5.1 & & $\mu g / L$ \\
\hline Tritium & GE & $\mathbf{U}$ & 0.7 & & $\mathrm{pCi} / \mathrm{ml}$ \\
\hline Uranium-234 & GE & U & 1 & & $\mathrm{pCi} / \mathrm{L}$ \\
\hline Uranium-235 & GE & U & 1 & & $\mathrm{pCi} / \mathrm{L}$ \\
\hline Uranium-238 & GE & $\mathbf{U}$ & 1 & & $\mathrm{pCi} / \mathrm{L}$ \\
\hline Vanadium & $G E$ & $\mathbf{U}$ & 8 & & $\mu g / L$ \\
\hline Yttrium-88 & $\mathrm{GE}$ & $\mathbf{U}$ & 60 & & $\mathrm{pCi} / \mathrm{L}$ \\
\hline Zinc & GE & $\mathbf{U}$ & 2 & & $\mu g / L$ \\
\hline Zinc-65 & $G E$ & $\mathrm{U}$ & 20 & & $\mathrm{pCi} / \mathrm{L}$ \\
\hline
\end{tabular}


Table 34. QA2 Laboratory Analyses

Collected from carboy used to transport all deionized water used in field activities.

Field Measurements:

Sample Date: 07/27/92

pH: NA

Specific Conductance: NA

\begin{tabular}{|c|c|c|c|c|c|}
\hline Analyte & Lab & Mod & $\begin{array}{c}7 / 92 \\
\text { Result }\end{array}$ & $A \propto C$ & Units \\
\hline Alkalinity & GE & V & 1.6 & & $\mathrm{mg} / \mathrm{L}$ \\
\hline Aluminum & GE & $\mathrm{U}$ & 20 & & $\mu \mathrm{g} / \mathrm{L}$ \\
\hline Americium-241 & GE & $\mathrm{U}$ & 1 & & $\mathrm{pCi} / \mathrm{L}$ \\
\hline Ammonia nitrogen & GE & $\mathrm{U}$ & 0.1 & & $\mathrm{mg} / \mathrm{L}$ \\
\hline Antimony & GE & $\mathrm{U}$ & 2 & & $\mu g / L$ \\
\hline Antimony-125 & GE & $\mathbf{U}$ & 20 & & $\mathrm{pC} / / \mathrm{L}$ \\
\hline Arsenic & GE & $\mathrm{U}$ & 2 & & $\mu g / L$ \\
\hline Barium & GE & U & 3 & & $\mu g / L$ \\
\hline Beryllium & $\mathrm{GE}$ & $\mathbf{U}$ & 3 & & $\mu g / L$ \\
\hline Cadmium & GE & U & 2 & & $\mu \mathrm{g} / \mathrm{L}$ \\
\hline Calcium & GE & U & 10 & & $\mu g / L$ \\
\hline Cerium-144 & $\mathrm{GE}$ & $\mathbf{U}$ & 60 & & $\mathrm{pCi} / \mathrm{L}$ \\
\hline Cesium-134 & GE & U & 10 & & $\mathrm{pCi} / \mathrm{L}$ \\
\hline Cesium-137 & GE & $\mathrm{U}$ & 10 & & $\mathrm{pCi} / \mathrm{L}$ \\
\hline Chloride & GE & U & 0.25 & & $\mathrm{mg} / \mathrm{L}$ \\
\hline Chromium & GE & $\mathrm{U}$ & 4 & & $\mu \mathrm{g} / \mathrm{L}$ \\
\hline Cobalt-57 & GE & U & 10 & & $\mathrm{pCi} / \mathrm{L}$ \\
\hline Cobalt-60 & GE & $\mathrm{U}$ & 10 & & $\mathrm{pCi} / \mathrm{L}$ \\
\hline Copper & GE & $U$ & 4 & & $\mu \mathrm{g} / \mathrm{L}$ \\
\hline Curium-242 & GE & U & 1 & & $\mathrm{pC} \mathrm{i} / \mathrm{L}$ \\
\hline Curium-243,244 & $\mathrm{GE}$ & U & 1 & & $\mathrm{pCi} / \mathrm{L}$ \\
\hline Europium-152 & GE & $\mathbf{U}$ & 40 & & $\mathrm{pCi} / \mathrm{L}$ \\
\hline Europium-154 & GE & $\mathrm{U}$ & 20 & & $\mathrm{pCi} / \mathrm{L}$ \\
\hline Europium-155 & GE & $\mathrm{U}$ & 30 & & $\mathrm{pCi} / \mathrm{L}$ \\
\hline Fluoride & $\mathrm{GE}$ & $\mathbf{U}$ & 0.1 & & $\mathrm{mg} / \mathrm{L}$ \\
\hline Gross Alpha & GE & $\mathbf{U}$ & 2 & & $\mathrm{pCi} / \mathrm{L}$ \\
\hline Hardness & GE & $\mathbf{U}$ & 1 & & $\mathrm{mg} / \mathrm{L}$ \\
\hline Iodine-129 & $\mathrm{TE}$ & U & 2 & & $\mathrm{pCi} / \mathrm{L}$ \\
\hline Iron & GE & $\mathbf{U}$ & 4 & & $\mu g / L$ \\
\hline Lead & GE & $\mathbf{U}$ & 3 & & $\mu g / L$ \\
\hline Magnesium & $\mathrm{GE}$ & U & 2 & & $\mu g / L$ \\
\hline Manganese & GE & U & 2 & & $\mu g / L$ \\
\hline Manganese-54 & GE & $\mathbf{U}$ & 10 & & $\mathrm{pCi} / \mathrm{L}$ \\
\hline Mercury & GE & $\mathrm{U}$ & 0.2 & & $\mu \mathrm{g} / \mathrm{L}$ \\
\hline Neptunium-237 & $\mathrm{TE}$ & $\mathbf{U}$ & 10 & & $\mathrm{pCi} / \mathrm{L}$ \\
\hline Nickel & GE & $\mathbf{U}$ & 4 & & $\mu g / L$ \\
\hline Nitrate as nitrogen & GE & U & 0.05 & & $\mathrm{mg} / \mathrm{L}$ \\
\hline Nonvolatile beta & GE & $\mathbf{U}$ & 2 & & $\mathrm{pCi} / \mathrm{L}$ \\
\hline Plutonium-238 & $\mathrm{GE}$ & $\mathrm{U}$ & 1 & & $\mathrm{pCi} / \mathrm{L}$ \\
\hline Plutonium-239,240 & GE & $\mathrm{U}$ & 1 & & $\mathrm{pCi} / \mathrm{L}$ \\
\hline Potassium & GE & $\mathbf{U}$ & 500 & & $\mu g / L$ \\
\hline Potassium-40 & GE & $\mathbf{U}$ & 110 & & $\mathrm{pCi} / \mathrm{L}$ \\
\hline Promethium-144 & GE & $\mathbf{U}$ & 10 & & $\mathrm{pCi} / \mathrm{L}$ \\
\hline Promethium-146 & GE & $\mathbf{U}$ & 10 & & $\mathrm{pCi} / \mathrm{L}$ \\
\hline
\end{tabular}


(Table 34. Continued)

\begin{tabular}{|c|c|c|c|c|c|}
\hline \multirow{2}{*}{ Analyte } & \multicolumn{5}{|c|}{$7 / 92$} \\
\hline & Lab & Mod & Result & Acc & Units \\
\hline Radium-226 & $\mathrm{GE}$ & $\bar{U}$ & 1 & & $\mathrm{pCi} / \mathrm{L}$ \\
\hline Radium-228 & $\mathrm{TE}$ & $\mathrm{U}$ & 1 & & $\mathrm{pCi} / \mathrm{L}$ \\
\hline Ruthenium-106 & $\mathrm{GE}$ & $\mathrm{U}$ & 90 & & $\mathrm{pCi} / \mathrm{L}$ \\
\hline Selenium & $\mathrm{GE}$ & $\mathbf{U}$ & 2 & & $\mu \mathrm{g} / \mathrm{L}$ \\
\hline Silver & GE & $\mathrm{U}$ & 2 & & $\mu g / L$ \\
\hline Sodium & GE & & 17.1 & & $\mu g / L$ \\
\hline Sodium-22 & GE & $\mathbf{U}$ & 10 & & $\mathrm{pCi} / \mathrm{L}$ \\
\hline Strontium-90 & GE & $\mathbf{U}$ & 2 & & $\mathrm{pCi} / \mathrm{L}$ \\
\hline Technetium-99 & GE & $\mathbf{U}$ & 300 & & $\mathrm{pCi} / \mathrm{L}$ \\
\hline Tetrachloroethylene & GE & $\mathbf{U}$ & 1 & & $\mu \mathrm{g} / \mathrm{L}$ \\
\hline Thallium & GE & U & 2 & & $\mu g / L$ \\
\hline Thorium-228 & GE & $\mathbf{U}$ & 1 & & $\mathrm{pCi} / \mathrm{L}$ \\
\hline Thorium-230 & GE & & 1.58 & 0.7 & $\mathrm{pCi} / \mathrm{L}$ \\
\hline Thorium-232 & GE & $\mathrm{U}$ & 1 & & $\mathrm{pCi} / \mathrm{L}$ \\
\hline Tin & GE & $\mathbf{U}$ & 2 & & $\mu g / L$ \\
\hline Total organic carbon & GE & U & 1 & & $\mathrm{mg} / \mathrm{L}$ \\
\hline Total organic halogens & GE & U & 5 & & $\mu g / L$ \\
\hline Total phenols & GE & & 5.9 & & $\mu g / L$ \\
\hline Tritium & GE & U & 0.7 & & $\mathrm{pCi} / \mathrm{ml}$ \\
\hline Uranium-234 & GE & $\mathbf{U}$ & 1 & & $\mathrm{pCi} / \mathrm{L}$ \\
\hline Uranium-235 & GE & $\mathrm{U}$ & 1 & & $\mathrm{pCi} / \mathrm{L}$ \\
\hline Uranium-238 & GE & $\mathrm{U}$ & 1 & & $\mathrm{pCi} / \mathrm{L}$ \\
\hline Vanadium & GE & U & 8 & & $\mu g / L$ \\
\hline Yttrium-88 & GE & $\mathbf{U}$ & 60 & & $\mathrm{pCi} / \mathrm{L}$ \\
\hline Zinc & GE & $\mathrm{U}$ & 2 & & $\mu g / L$ \\
\hline Zinc-65 & GE & $\mathbf{U}$ & 20 & & $\mathrm{pCi} / \mathrm{L}$ \\
\hline
\end{tabular}


Table 35. QA3 Laboratory Analyses

Collected from post-decontamination equipment rinse water.

Field Measurements: Trip blank

Sample Date: 07/27/92

pH: NA

Specific Conductance: NA

\begin{tabular}{|c|c|c|c|c|c|}
\hline \multirow{2}{*}{ Analyte } & \multicolumn{5}{|c|}{$7 / 92$} \\
\hline & Lab & Mod & Result & Acc & Units \\
\hline Alkalinity & GE & $\mathrm{v}$ & 2.63 & & $\mathrm{mg} / \mathrm{L}$ \\
\hline Aluminum & $\mathrm{GE}$ & & 40.7 & & $\mu g / L$ \\
\hline Americium-241 & GE & $\mathrm{U}$ & 1 & & $\mathrm{pCi} / \mathrm{L}$ \\
\hline Ammonia nitrogen & $\mathrm{GE}$ & $\mathbf{U}$ & 0.1 & & $\mathrm{mg} / \mathrm{L}$ \\
\hline Antimony & $\mathrm{GE}$ & $\mathrm{U}$ & 2 & & $\mu g / L$ \\
\hline Antimony-125 & GE & $\mathbf{U}$ & 20 & & $\mathrm{pCi} / \mathrm{L}$ \\
\hline Arsenic & GE & $\mathbf{U}$ & 2 & & $\mu g / L$ \\
\hline Barium & GE & $U$ & 3 & & $\mu g / L$ \\
\hline Beryllium & GE & $\mathrm{U}$ & 3 & & $\mu \mathrm{g} / \mathrm{L}$ \\
\hline Cadmium & GE & $\mathbf{U}$ & 2 & & $\mu g / L$ \\
\hline Calcium & $\mathrm{GE}$ & & 71.3 & & $\mu g / L$ \\
\hline Cerium-144 & GE & $\mathbf{U}$ & 60 & & $\mathrm{pCi} / \mathrm{L}$ \\
\hline Cesium-134 & GE & $\mathrm{U}$ & 10 & & $\mathrm{pCi} / \mathrm{L}$ \\
\hline Cesium-137 & GE & $\mathrm{U}$ & 10 & & $\mathrm{pCi} / \mathrm{L}$ \\
\hline Chloride & $\mathrm{GE}$ & $\mathbf{U}$ & 0.25 & & $\mathrm{mg} / \mathrm{L}$ \\
\hline Chromium & $G E$ & $\mathrm{U}$ & 4 & & $\mu g / L$ \\
\hline Cobalt-57 & $\mathrm{GE}$ & $\mathbf{U}$ & 10 & & $\mathrm{pCi} / \mathrm{L}$ \\
\hline Cobalt-60 & $\mathrm{GE}$ & $U$ & 10 & & $\mathrm{pCi} / \mathrm{L}$ \\
\hline Copper & $\mathrm{GE}$ & $U$ & 4 & & $\mu g / L$ \\
\hline Currium-242 & $\mathrm{GE}$ & $U$ & 1 & & $\mathrm{pCi} / \mathrm{L}$ \\
\hline Curium-243,244 & GE & $\mathbf{U}$ & 1 & & $\mathrm{pCi} / \mathrm{L}$ \\
\hline Europium-152 & $\mathrm{GE}$ & $\mathbf{U}$ & 40 & & $\mathrm{pCi} / \mathrm{L}$ \\
\hline Europium-154 & $\mathrm{GE}$ & $\mathrm{U}$ & 20 & & $\mathrm{pCi} / \mathrm{L}$ \\
\hline Europium-155 & $\mathrm{GE}$ & $\mathrm{U}$ & 30 & & $\mathrm{pCi} / \mathrm{L}$ \\
\hline Fluoride & $\mathrm{GE}$ & $\mathrm{U}$ & 0.1 & & $\mathrm{mg} / \mathrm{L}$ \\
\hline Gross alpha & $\mathrm{GE}$ & $\mathbf{U}$ & 2 & & $\mathrm{pCi} / \mathrm{L}$ \\
\hline Hardness & $\mathrm{GE}$ & & 1 & & $\mathrm{mg} / \mathrm{L}$ \\
\hline Iodine-129 & $\mathrm{TE}$ & $\mathrm{U}$ & 2 & & $\mathrm{pCi} / \mathrm{L}$ \\
\hline Iron & GE & & 17.6 & & $\mu g / L$ \\
\hline Lead & GE & & 35.2 & & $\mu \mathrm{g} / \mathrm{L}$ \\
\hline Magnesium & $\mathrm{GE}$ & & 7.65 & & $\mu g / L$ \\
\hline Manganese & GE & $\mathbf{U}$ & 2 & & $\mu g / L$ \\
\hline Manganese- 54 & GE & $\mathbf{U}$ & 10 & & $\mathrm{pCi} / \mathrm{L}$ \\
\hline Mercury & $\mathrm{GE}$ & $\mathrm{U}$ & 0.2 & & $\mu g / L$ \\
\hline Neptunium-237 & $\mathrm{TE}$ & $\mathrm{U}$ & 10 & & $\mathrm{pCi} / \mathrm{L}$ \\
\hline Nickel & GE & $\mathrm{U}$ & 4 & & $\mu g / L$ \\
\hline Nitrate as nitrogen & GE & & 0.06 & & $\mathrm{mg} / \mathrm{L}$ \\
\hline Nonvolatile beta & $\mathrm{GE}$ & $\mathbf{U}$ & 2 & & $\mathrm{pCi} / \mathrm{L}$ \\
\hline Plutonium-238 & $\mathrm{GE}$ & $\mathbf{U}$ & 1 & & $\mathrm{pCi} / \mathrm{L}$ \\
\hline Plutonium-239,240 & $G E$ & $\mathbf{U}$ & 1 & & $\mathrm{pCi} / \mathrm{L}$ \\
\hline Potassium & $\mathrm{GE}$ & $\mathbf{U}$ & 500 & & $\mu g / L$ \\
\hline Potassium-40 & $\mathrm{GE}$ & $\mathbf{U}$ & 110 & & $\mathrm{pCi} / \mathrm{L}$ \\
\hline Promethium-144 & $\mathrm{GE}$ & $\mathbf{U}$ & 10 & & $\mathrm{pCi} / \mathrm{L}$ \\
\hline Promethium-146 & $\mathrm{GE}$ & $\mathbf{U}$ & 10 & & $\mathrm{pCi} / \mathrm{L}$ \\
\hline
\end{tabular}


(Table 35. Continued)

\begin{tabular}{|c|c|c|c|c|c|}
\hline Analyte & Lab & Mod & $\begin{array}{c}7 / 92 \\
\text { Result }\end{array}$ & Ace & Units \\
\hline Radium-226 & $\overline{G E}$ & $\overline{\mathrm{U}}$ & 1 & & $\mathrm{pCi} / \mathrm{L}$ \\
\hline Radium-228 & $\mathrm{TE}$ & $\mathrm{U}$ & 1 & & $\mathrm{pCi} / \mathrm{L}$ \\
\hline Rutbenium-106 & GE & $\mathbf{U}$ & 90 & & $\mathrm{pCi} / \mathrm{L}$ \\
\hline Selenium & GE & $\mathbf{U}$ & 2 & & $\mu g / L$ \\
\hline Silver & GE & U & 2 & & $\mu g / L$ \\
\hline Sodium & GE & & 126 & & $\mu g / L$ \\
\hline Sodium-22 & GE & U & 10 & & $\mathrm{pC} \mathbf{i} / \mathrm{L}$ \\
\hline Strontium-90 & GE & $\mathrm{U}$ & 2 & & $\mathrm{pCi} / \mathrm{L}$ \\
\hline Technetium-99 & GE & U & 300 & & $\mathrm{pCi} / \mathrm{L}$ \\
\hline Tetrachloroethylene & GE & U & 1 & & $\mu g / L$ \\
\hline Thallium & GE & $\mathrm{U}$ & 2 & & $\mu g / L$ \\
\hline Thorium-228 & GE & U & 1 & & $\mathrm{pCi} / \mathrm{L}$ \\
\hline Thorium-230 & GE & $\mathbf{U}$ & 1 & & $\mathrm{pCi} / \mathrm{L}$ \\
\hline Thorium-232 & GE & $\mathrm{U}$ & 1 & & $\mathrm{pCi} / \mathrm{L}$ \\
\hline Tin & $\mathrm{GE}$ & & 2.37 & & $\mu g / L$ \\
\hline Total organic carbon & $\mathrm{GE}$ & $\mathrm{U}$ & 1 & & $\mathrm{mg} / \mathrm{L}$ \\
\hline Total organic halogens & GE & JQU & 5 & & $\mu g / L$ \\
\hline Total phenols & GE & $\bar{U}$ & 5 & & $\mu \mathrm{g} / \mathrm{L}$ \\
\hline Tritium & $\mathrm{GE}$ & U & 0.7 & & $\mathrm{pCi} / \mathrm{ml}$ \\
\hline Uranium-234 & GE & U & 1 & & $\mathrm{pCi} / \mathrm{L}$ \\
\hline Uranium-235 & GE & $\mathrm{U}$ & 1 & & $\mathrm{pCi} / \mathrm{L}$ \\
\hline Uranium-238 & GE & $\mathrm{U}$ & 1 & & $\mathrm{pCi} / \mathrm{L}$ \\
\hline Vanadium & GE & $\mathrm{U}$ & 8 & & $\mu \mathrm{g} / \mathrm{L}$ \\
\hline Ytrium-88 & $\mathrm{GE}$ & U & 60 & & $\mathrm{pCi} / \mathrm{L}$ \\
\hline Zinc & GE & U & 2 & & $\mu g / L$ \\
\hline Zinc-65 & GE & U & 34 & & $\mathrm{pCi} / \mathrm{L}$ \\
\hline
\end{tabular}


Table 36. QA4 Laboratory Analyses

Collected from post-decontamination equipment rinse water.

Field Measurements: Trip blank

Sample Date: NA

pH: NA

Specific Conductance: NA

\begin{tabular}{|c|c|c|c|c|c|}
\hline Analyte & Lab & Mod & $\begin{array}{c}7 / 92 \\
\text { Result }\end{array}$ & Acc & Units \\
\hline Alkalinity & $\overline{G E}$ & UV & 1 & & $\mathrm{mg} / \mathrm{L}$ \\
\hline Aluminum & $\mathrm{GE}$ & & 41.8 & & $\mu g / L$ \\
\hline Americium-241 & $\mathrm{GE}$ & $\mathbf{U}$ & 1 & & $\mathrm{pCi} / \mathrm{L}$ \\
\hline Ammonia nitrogen & $\mathrm{GE}$ & U & 0.1 & & $\mathrm{mg} / \mathrm{L}$ \\
\hline Antimony & GE & $\mathrm{U}$ & 2 & & $\mu g / L$ \\
\hline Antimony-125 & GE & $\mathbf{U}$ & 20 & & $\mathrm{pCi} / \mathrm{L}$ \\
\hline Arsenic & GE & $\mathrm{U}$ & 2 & & $\mu g / L$ \\
\hline Barium & GE & $\mathrm{U}$ & 3 & & $\mu g / L$ \\
\hline Beryllium & $\mathrm{GE}$ & U & 3 & & $\mu g / L$ \\
\hline Cadmium & $G E$ & $\mathbf{U}$ & 2 & & $\mu \mathrm{g} / \mathrm{L}$ \\
\hline Calcium & GE & & 36.6 & & $\mu g / L$ \\
\hline Cerium-144 & $G E$ & U & 60 & & $\mathrm{pCi} / \mathrm{L}$ \\
\hline Cesium-134 & GE & $\mathbf{U}$ & 10 & & $\mathrm{pCi} / \mathrm{L}$ \\
\hline Cesium-137 & GE & U & 10 & & $\mathrm{pCi} / \mathrm{L}$ \\
\hline Chloride & $\mathrm{GE}$ & $\mathbf{U}$ & 0.25 & & $\mathrm{mg} / \mathrm{L}$ \\
\hline Chromium & GE & $\mathbf{U}$ & 4 & & $\mu g / L$ \\
\hline Cobalt-57 & $\mathrm{GE}$ & $\mathbf{U}$ & 10 & & $\mathrm{pCi} / \mathrm{L}$ \\
\hline Cobalt- 60 & $G E$ & $\mathrm{U}$ & 10 & & $\mathrm{pCi} / \mathrm{L}$ \\
\hline Copper & $\mathrm{GE}$ & $\mathbf{U}$ & 4 & & $\mu \mathrm{g} / \mathrm{L}$ \\
\hline Curium-242 & GE & $\mathbf{U}$ & 1 & & $\mathrm{PCi} / \mathrm{L}$ \\
\hline Curium-243,244 & GE & $\mathrm{U}$ & 1 & & $\mathrm{pCi} / \mathrm{L}$ \\
\hline Europium-152 & $\mathrm{GE}$ & $\mathrm{U}$ & 40 & & $\mathrm{pCi} / \mathrm{L}$ \\
\hline Europium-154 & $\mathrm{GE}$ & $\mathbf{U}$ & 20 & & $\mathrm{pCi} / \mathrm{L}$ \\
\hline Europium-155 & $\mathrm{GE}$ & $\mathbf{U}$ & 30 & & $\mathrm{pCi} / \mathrm{L}$ \\
\hline Fluoride & $\mathrm{GE}$ & $\mathrm{U}$ & 0.1 & & $\mathrm{mg} / \mathrm{L}$ \\
\hline Gross alpha & $\mathrm{GE}$ & $\mathrm{U}$ & 2 & & $\mathrm{pCi} / \mathrm{L}$ \\
\hline Hardness & $\mathrm{GE}$ & & 1 & & $\mathrm{mg} / \mathrm{L}$ \\
\hline Iodine- 129 & TE & $\mathbf{U}$ & 2 & & $\mathrm{pCi} / \mathrm{L}$ \\
\hline Iron & $\mathrm{GE}$ & & 22.2 & & $\mu g / L$ \\
\hline Lead & $\mathrm{GE}$ & & 42.8 & & $\mu g / L$ \\
\hline Magnesium & $\mathrm{GE}$ & & 2.93 & & $\mu g / L$ \\
\hline Manganese & $\mathrm{GE}$ & $\mathbf{U}$ & 2 & & $\mu g / L$ \\
\hline Manganese-54 & $\mathrm{GE}$ & $\mathrm{U}$ & 10 & & $\mathrm{pCi} / \mathrm{L}$ \\
\hline Mercury & $\mathrm{GE}$ & $\mathbf{U}$ & 0.2 & & $\mu g / L$ \\
\hline Neptunium-237 & TE & $\mathbf{U}$ & 10 & & $\mathrm{pCi} / \mathrm{L}$ \\
\hline Nickel & $\mathrm{GE}$ & $\mathbf{U}$ & 4 & & $\mu g / L$ \\
\hline Nitrate as nitrogen & $\mathrm{GE}$ & & 0.05 & & $\mathrm{mg} / \mathrm{L}$ \\
\hline Nonvolatile beta & $\mathrm{GE}$ & $\mathbf{U}$ & 2 & & $\mathrm{pCi} / \mathrm{L}$ \\
\hline Plutonium-238 & $\mathrm{GE}$ & $\mathrm{U}$ & 1 & & $\mathrm{pCi} / \mathrm{L}$ \\
\hline Plutonium-239,240 & GE & $\mathbf{U}$ & 1 & & $\mathrm{pCi} / \mathrm{L}$ \\
\hline Potassium & $\mathrm{GE}$ & $\mathbf{U}$ & 500 & & $\mu \mathrm{g} / \mathrm{L}$ \\
\hline Potassium-40 & $\mathrm{GE}$ & $\mathbf{U}$ & 110 & & $\mathrm{pCi} / \mathrm{L}$ \\
\hline Promethium-144 & GE & $\mathbf{U}$ & 10 & & $\mathrm{pCi} / \mathrm{L}$ \\
\hline Promethium-146 & $\mathrm{GE}$ & $\mathbf{U}$ & 10 & & $\mathrm{pCi} / \mathrm{L}$ \\
\hline
\end{tabular}


(Table 36. Continued)

\begin{tabular}{|c|c|c|c|c|c|}
\hline \multirow{2}{*}{ Analyte } & \multicolumn{5}{|c|}{$7 / 92$} \\
\hline & Lab & Mod & Result & Acc & Units \\
\hline Radium-226 & $\mathrm{GE}$ & $\mathbf{U}$ & 1 & & $\mathrm{pCi} / \mathrm{L}$ \\
\hline Radium-228 & TE & U & 1 & & $\mathrm{pCi} / \mathrm{L}$ \\
\hline Ruthenium-106 & $G E$ & u & 90 & & $\mathrm{pCi} / \mathrm{L}$ \\
\hline Selenium & $\mathrm{GE}$ & $\mathrm{U}$ & 2 & & $\mu g / L$ \\
\hline Silver & $\mathrm{GE}$ & $\mathbf{U}$ & 2 & & $\mu g / L$ \\
\hline Sodium & GE & & 75.9 & & $\mu g / L$ \\
\hline Sodium-22 & GE & $\mathbf{U}$ & 10 & & $\mathrm{pCi} / \mathrm{L}$ \\
\hline Strontium-90 & GE & U & 2 & & $\mathrm{pCi} / \mathrm{L}$ \\
\hline Technetium-99 & GE & U & 300 & & $\mathrm{pCi} / \mathrm{L}$ \\
\hline Tetrachloroethylene & $\mathrm{GE}$ & $\mathrm{U}$ & 1 & & $\mu g / L$ \\
\hline Thallium & GE & $\mathrm{U}$ & 2 & & $\mu g / L$ \\
\hline Thorium-228 & GE & $\mathbf{U}$ & 1 & & $\mathrm{pCi} / \mathrm{L}$ \\
\hline Thorium-230 & GE & $\mathrm{U}$ & 1 & & $\mathrm{pCi} / \mathrm{L}$ \\
\hline Thorium-232 & $\mathrm{GE}$ & $\mathrm{U}$ & 1 & & $\mathrm{pCi} / \mathrm{L}$ \\
\hline Tin & GE & $\mathbf{U}$ & 2 & & $\mu g / L$ \\
\hline Total organic carbon & GE & $\mathrm{U}$ & 0.85 & & $\mathrm{mg} / \mathrm{L}$ \\
\hline Total organic halogens & GE & JQU & 5 & & $\mu g / L$ \\
\hline Total phenols & GE & $\mathrm{U}$ & 5 & & $\mu g / L$ \\
\hline Tritium & $\mathrm{GE}$ & $\mathbf{U}$ & 0.7 & & $\mathrm{pCi} / \mathrm{ml}$ \\
\hline Uranium-234 & $\mathrm{GE}$ & $\mathrm{U}$ & 1 & & $\mathrm{pCi} / \mathrm{L}$ \\
\hline Uranium-235 & $\mathrm{GE}$ & $\mathbf{U}$ & 1 & & $\mathrm{pCi} / \mathrm{L}$ \\
\hline Uranium-238 & GE & $\mathrm{U}$ & 1 & & $\mathrm{pCi} / \mathrm{L}$ \\
\hline Vanadium & GE & $\mathbf{U}$ & 8 & & $\mu g / L$ \\
\hline Yttrium-88 & $\mathrm{GE}$ & $\mathbf{U}$ & 60 & & $\mathrm{pCi} / \mathrm{L}$ \\
\hline Zinc & $\mathrm{GE}$ & $\mathbf{U}$ & 2 & & $\mu g / L$ \\
\hline Zinc-65 & GE & U & 20 & & $\mathrm{pCi} / \mathrm{L}$ \\
\hline
\end{tabular}




\section{Appendix A}

\section{July 1992 Sampling Event}


WSRC-TR-93-289 


\section{Introduction}

From 1955 to 1988, low-level radioactive wastewater generated by chemical separation processes within the General Separations Area (GSA) were discharged to seepage basins in the $F$ and $H$ Areas of the Savannah River Site (SRS). These basins were designed to permit the infiltration of the process wastewaters. As wastewater percolated downward through the basins, chemical and radioactive constituents were retained or delayed in the subsoils.

An extensive study aimed at characterizing the groundwater seeping into Fourmile Branch and its associated seepline was conducted in 1988 and 1989 (Haselow et al. 1990). Results of this study suggested that contaminants leaching from the $F$ and $H$ Area seepage basins were impacting the Fourmile Branch wetland system. The seepage basins were closed in 1988 and capped and sealed in 1990. This effectively eliminated the hydraulic head driving the migration of contaminants from the basins. It has been hypothesized that, after the elimination of the head, annual rainfall amounts would be sufficient to dilute and flush out contaminants remaining in the subsoils and groundwaters beneath the basins. Westinghouse Savannah River Company has designed a semi-annual sampling and analytical program for the Fourmile Branch (FMB) seepline and stream water to test the hypothesis.

Twelve seepline water and four stream water sampling locations are included in the semi-annual monitoring. These sampling locations include three background locations. Sampling locations were selected by WSRC based on previous sampling results. Sampling location numbers and SRS coordinates are presented in Table A-1.
The first of the three scheduled semi-annual sampling events took place from July 20, 1992, through July 29, 1992. This report summarizes the results of the field monitoring obtained during this event and presents a brief comparison to previous data.

Table A-1. Sample Location Numbers and SRS Coordinates

\begin{tabular}{lcc} 
Seepline & \multicolumn{2}{c}{ SRS Coordinates } \\
& North & E2st \\
\hline HArea & & \\
HSP008 & 71005 & 56990 \\
HSP029 & 71278 & 56257 \\
HSP043 & 71644 & 55722 \\
HSP060 & 71629 & 55190 \\
HSP092 & 72672 & 54129 \\
FArea & & \\
FSP012 & 73602 & 49644 \\
FSP032 & 73367 & 50258 \\
FSP047 & 73609 & 50607 \\
FSP204 & 73281 & 48801 \\
FSP290 & 73160 & 46865 \\
Background & & \\
BG001 & Seepline & \\
BG002 & Seepline & \\
BG003 & Stream water & \\
Stream Sites & & \\
FMC0001H & 70350 & 57050 \\
FMC0002H & 72600 & 53000 \\
FMC0001F & 72200 & 43900
\end{tabular}

${ }^{1}$ The locations of background samples were within the grid identified by Site Use Grid Maps 13 and 14 as $71750 \mathrm{~N}-60000 \mathrm{~N}$ and $40000 \mathrm{E}-70000 \mathrm{E}$. The exact location was identified by ESS technical personnel. 


\section{Experimental Methods}

\section{Mobilization}

Labeled sample bottles, with preservatives added as necessary, "blue ice", and coolers were provided by the following pairs of subcontracted analytical laboratories: General Engineering Laboratories (non-radiological analyses)/ Environmental Physics (radiological analyses) and Roy F. Weston (non-radiological analyses)/Clemson Technical Center (radiological analyses). Additional bottles for onsite analysis of total activity were supplied by the WSRCEMS Radiological Laboratory. WSRC provided chain-ofcustody forms and packaging materials. The sample bottles needed for one day of sampling were separated by station and carried to the sampling station.

\section{Equipment List}

The following equipment was used during seepline groundwater sampling.

Rubber gloves

Safety glasses

Clipboard, waterproof pens, waterproof markers

Field data logbook

Chain-of-custody forms

Shipping orders

Samples bottles

Backpacks

Shovel, post-hole digger, hatchet or axe

Peristaltic pump

Paper and cloth towels

Ziplock bags

Coolers with cool packs

Bubble pack

Sampling buckets (5-gallon) with lids

Water quality meters ( $\mathrm{pH}$, conductivity, redox)

Silicone (Silastic) tubing

1 one-liter Nalgene bottle for each station sampled

0.45 micron filters and filtering equipment

Tyvek aprons

The following equipment was used during stream water sampling:

Rubber gloves

Safety glasses.

Clipboard, waterproof pens, waterproof markers

Field data logbook

Chain-of-custody forms

Shipping orders

Sample bottles

Backpacks
Paper and cloth towels

Ziplock bags

Coolers with cool packs

Bubble pack

Water quality meters ( $\mathrm{pH}$, conductivity, redox)

1 one-liter Nalgene bottle for each station sampled

0.45 micron filters and filtering equipment

Life jackets

Hip boots

Tyvek aprons

\section{Decontamination Procedures}

Cleaning and decontamination procedures for all sampling equipment are outlined below. All sampler parts were decontaminated prior to the collection of each sample.

Sampling equipment was first cleaned with Milli- $Q$ water and phosphate-free laboratory detergent (Liquinox), using a brush, if necessary, to remove particulate matter and surface films. The equipment was then rinsed thoroughly with Milli-Q water. Finally, the equipment was rinsed two times with pesticide-grade methanol solvent and allow to air dry. When necessary, the dry equipment was wrapped with aluminum foil to prevent contamination during storage or transport.

All decontamination rinse waters were discharged to the ground. The methanol was collected in a pan and allowed to evaporate.

\section{Sample Collection Procedures}

\section{Groundwater}

All sample locations had been permanently marked by WSRC with a 1-inch Schedule 40 PVC stake driven two feet below grade. An identification number was written on each PVC stake.

After locating the sampling station, the sampling crew excavated a hole using a decontaminated stainless steel shovel. The hole was excavated within a three-foot radius of the PVC stake. Water was encountered in each hole at the depths indicated in Table A-2. The sampling bucket was placed into the hole and covered with a lid. One bucket was set at each location, except locations HSP008, HSP043, FSP047 and FSP290, where two buckets were set. The additional bucket was needed in order to collect sufficient water for duplicate and QA samples. The buckets were set out one day prior to sample collection to allow the sediment in the water to settle. The time between setting the bucket and sample collection was recorded in the field notebook. 
Table A-2. Depth Water Encountered

\begin{tabular}{ll}
\multicolumn{1}{c}{ Location } & \multicolumn{1}{c}{ Water Depth } \\
\hline H Area & \\
HSP008 & 8 inches \\
HSP029 & 2 inches \\
HSP043 & 2 feet \\
HSP060 & 2 inches \\
HSP092 & 1.5 feet \\
FArea & \\
FSP012 & 2 feet \\
FSP032 & 8 inches \\
FSP047 & Data not available \\
FSP204 & Surface \\
FSP290 & 1 foot \\
Background & \\
BG001 & 7 inches \\
BG002 & 8 inches
\end{tabular}

The 40-ml GCMS/VOA vials and the 1-liter sample bottle used for water to be filtered for metals analysis were filled first by dipping them into the bucket. This was done in a manner that avoids disturbance of the sediment. The VOA vial was filled completely so that no air bubbles were present in the sample.

The remaining samples were collected by pumping the water from the bucket to the remaining sample jars through Silastic (silicone) tubing, using a peristaltic pump powered by a 12-volt battery. New tubing was used for each sample location. The new tubing was flushed for 20 seconds with water from the bucket before the sampling crew collected the sample.

Samples collected for metals analysis were filtered in the field through a 0.45 -micron membrane filter to remove fine particulate matter from the water being analyzed. This filtering occurred within four hours of sample collection. The filtering apparatus was flushed with deionized or distilled water between filtering each sample.

Samples collected on July 22,1992 , were very turbid, possibly due to a rainfall event that occurted the previous evening. The turbidity caused filtering problems and increased field processing time. As a result, the field crew collected approximately one-half the volume of water required for metals analysis for the duplicate sample at station HSPO43 and were unable to collect the metals sample for QA-1S.
The $\mathrm{pH}$, conductivity, and redox potential of the water at each location were measured at the time of sampling. These readings were taken directly from the water collected in the five-gallon bucket and recorded in the field data logbook. The probes were rinsed with DI water prior to taking these measurements.

Blue ice was used to keep the samples cool from the time of sampling until they were received at the analytical laboratory.

At each sampling location, a 250-ml plastic sample container was filled with the water and sent to the WSRC EMS Radiological Laboratory to determine the total activity in the samples. These data were used to determine the packaging and shipping requirements of the specific samples.

Duplicate samples were collected at both HSP043 and FSP047 and sent to General Engineering/Environmental Physics and Roy F. Weston/Clemson for QA/QC purposes. A triplicate sample was collected from HSP008. This triplicate sample consisted of HSPO08 sent to General Engineering/Environmental Physics, QA-1S sent to General Engineering/Environmental Physics, and QA-1S sent to Roy F. Weston/Clemson. A triplicate sample was collected from FSP290. This triplicate sample consisted of FSP290 sent to General Engineering/Environmental Physics, QA3S sent to General Engineering/Environmental Physics, and QA-3S sent to Roy F. Weston/Clemson.

Two trip blanks were included for the semi-annual sampling event (QA-2S and QA-4S).

Two equipment rinsate samples (QA-3 and QA-4) were collected on July 27, 1992.

Two samples of Milli-Q water, one from the source (QA1) and one from the field carboy (QA-2), were collected on July 27, 1992, and sent to General Engineering.

At the end of each day, the samples were transported to the Health Protection office in the Central Shops area where the outside of the containers were scanned for radioactivity. The purpose of this scan was to identify any radiological health hazards associated with handling the samples. The samples were then transported to the laboratory at $704 \mathrm{~B}$, where they remained until cleared for shipment.

\section{Surface Water Sampling}

Collection of the surface water samples was performed by dipping the sample container directly into the stream water. This collection method minimizes alteration of the 
sample. Also, the potential for sample cross-contamination through the use of poorly decontaminated sampling equipment is eliminated. Sampling personnel wore hip boots and gloves to minimize exposure to potential contaminants.

The sample bottles to be used at each location were removed from the coolers and the bottle labels were completed with waterproof markers or ballpoint pens.

Surface grab samples were collected in the middle of the stream from the top of the water column. The container was placed into the water with the mouth of the container facing upstream so that water flowed directly into the container. Care was taken when opening and filling the botthes, since some of the bottles contained carefully measured amounts of chemical preservatives.

All containers, except the VOA vials, were filled to the shoulder with water. VOA vials were filled completely and capped so that no air bubbles were present in the sample. Water collected for metals analysis was filtered in the field prior to preservation. The filled sample containers were capped tightly and placed in a plastic ziplock bag. The samples were placed in coolers and kept cool.

The in situ $\mathrm{pH}$, conductivity, and redox potential of the stream was measured and recorded in the field notebook.

Evidence of sample collection, shipment, laboratory receipt, and laboratory custody until sample disposal must be documented to ensure the sample traceability scheme. Documentation was accomplished through a chain-of-custody record that contains the necessary information for individual sample identification and lists the individuals responsible for sample collection, shipment, and receipt, along with necessary signatures and dates. Completed chain-of-custody forms for this sampling event are presented in Appendix A of WSRC-TR-92-559. 


\section{Results}

The $\mathrm{pH}$, conductivity, and redox potential measurements collected in the field are summarized in Table A-3. The pH readings for $H$ Area seepline samples ranged from 4.80 to 6.32 , with an average value of 5.72 . The $\mathrm{pH}$ readings for $\mathrm{F}$ Area seepline samples ranged from 4.10 to 5.38, with an average value of 4.96 . The average $\mathrm{pH}$ of the background seepline samples was 4.91 . The conductivity readings for the seepline samples in $H$ Area ranged from $33 \mu \mathrm{mhos} / \mathrm{cm}$ to $237 \mu \mathrm{mhos} / \mathrm{cm}$, with an average value of $139 \mu \mathrm{mhos} /$ $\mathrm{cm}$. The conductivity readings for the seepline samples in F Area ranged from $46 \mu \mathrm{mhos} / \mathrm{cm}$ to $277 \mu \mathrm{mhos} / \mathrm{cm}$, with an average value of $122 \mu \mathrm{mhos} / \mathrm{cm}$. The average conductivity of the background seepline samples was $30 \mu \mathrm{mhos} /$ $\mathrm{cm}$. The redox potential readings for the seepline samples in $\mathrm{H}$ Area ranged from $107 \mathrm{mV}$ to $205 \mathrm{mV}$, with an average value of $158 \mathrm{mV}$. The redox potential readings for the seepline samples in F Area ranged from $53 \mathrm{mV}$ to $227 \mathrm{mV}$, with an average value of $148 \mathrm{mV}$. The average redox potential of the background seepline samples was $200 \mathrm{mV}$.

Table A-3. Water Quality Parameters Measured in the Field

\begin{tabular}{|c|c|c|c|c|c|c|c|}
\hline \multirow[b]{2}{*}{ Station } & \multirow[b]{2}{*}{$\begin{array}{c}\text { Date } \\
\text { Sampled }\end{array}$} & \multirow[b]{2}{*}{$\begin{array}{c}\text { Time } \\
\text { Sampled }\end{array}$} & \multicolumn{2}{|c|}{ SRS Coordinates } & \multirow[b]{2}{*}{$\begin{array}{c}\mathbf{p H} \\
\text { (pH units) }\end{array}$} & \multirow[b]{2}{*}{$\begin{array}{r}\text { Conductivity } \\
(\mu \mathrm{mhos} / \mathrm{cm}) \\
\end{array}$} & \multirow[b]{2}{*}{$\begin{array}{c}\text { Redox } \\
(\mathrm{mV}) \\
\end{array}$} \\
\hline & & & North & East & & & \\
\hline \multicolumn{8}{|l|}{ HArea } \\
\hline HSP008 & $7 / 23 / 92$ & $9: 30$ & 71005 & 56990 & 6.32 & 237 & 195 \\
\hline HSP029 & $7 / 12 / 92$ & $12: 30$ & 71278 & 56257 & 4.80 & 97 & 205 \\
\hline HSPO43 & $7 / 23 / 92$ & $11: 45$ & 71644 & 55722 & 5.73 & 155 & 175 \\
\hline HSP060 & $7 / 21 / 92$ & $\begin{array}{c}\text { Not } \\
\text { Recorded }\end{array}$ & 71629 & 55190 & 6.07 & 173 & 107 \\
\hline HSP092 & $7 / 21 / 92$ & $10: 47$ & 72672 & 54129 & 5.68 & 33 & 110 \\
\hline Average & & & & & 5.72 & 139 & 158 \\
\hline \multicolumn{8}{|l|}{ F Area } \\
\hline FSP012 & $7 / 28 / 92$ & $11: 45$ & 73602 & 49644 & 5.14 & 106 & 53 \\
\hline FSP032 & $7 / 28 / 92$ & $10: 30$ & 73367 & 50258 & 4.10 & 95 & 227 \\
\hline FSP047 & $7 / 28 / 92$ & $9: 00$ & 73609 & 50607 & 5.38 & 88 & 120 \\
\hline FSP204 & $7 / 28 / 92$ & $11: 30$ & 7328 & 48801 & 5.35 & 277 & 180 \\
\hline FSP290 & $7 / 29 / 92$ & $9: 30$ & 73160 & 46865 & 5.83 & 46 & 160 \\
\hline Average & & & & & 4.96 & 122 & 148 \\
\hline \multicolumn{8}{|l|}{ Background } \\
\hline BG001 & $7 / 29 / 92$ & $11: 30$ & & & 4.82 & 21 & 265 \\
\hline $\mathrm{BGO02}$ & $7 / 29 / 92$ & $12: 00$ & & & 5.00 & 38 & 135 \\
\hline *BGO03 & $7 / 22 / 92$ & $11: 26$ & & & 5.80 & 20 & -13 \\
\hline $\begin{array}{l}\text { Average } \\
\text { (BG001 and BG002) }\end{array}$ & & & & & 4.96 & 122 & 148 \\
\hline \multicolumn{8}{|l|}{ Stream Sites } \\
\hline FMCOO1H & $7 / 22 / 92$ & $12: 20$ & 70350 & 57050 & 7.19 & 86 & 178 \\
\hline $\mathrm{FMCOO2H}$ & $7 / 22 / 92$ & $10: 30$ & 72600 & 53000 & 6.67 & 94 & 136 \\
\hline FMCOO1F & $7 / 22 / 92$ & $9: 48$ & 72200 & 43900 & 6.75 & 70 & 136 \\
\hline Average & & & & & 6.87 & & \\
\hline
\end{tabular}

*Stream Site 
The $\mathrm{pH}$ readings for the stream samples ranged from 6.67 to 7.19 , with an average value of 6.87 . The $\mathrm{pH}$ of the background stream sample was 5.80 . The conductivity readings for the stream samples ranged from $70 \mu \mathrm{mhos} / \mathrm{cm}$ to 94 $\mu \mathrm{mhos} / \mathrm{cm}$, with an average value of $83 \mu \mathrm{mhos} / \mathrm{cm}$. The conductivity of the background stream sample was 20 $\mu \mathrm{mhos} / \mathrm{cm}$. The redox potential readings for the stream samples ranged from $136 \mathrm{mV}$ to $178 \mathrm{mV}$, with an average value of $150 \mathrm{mV}$. The redox potential of the background stream sample was $-13 \mathrm{mV}$.

The conductivity and $\mathrm{pH}$ of the seepline water was measured previously in March 1989 (Haselow et al. 1990) and in May 1992 (Dixon et al. 1992). This previous data is summarized and current data presented in Tables A-4 and A-5 and displayed in Figures A-1 through A-4.

Table A-4. Summary of Conductivity Measurements

\begin{tabular}{lccccc} 
& \multicolumn{5}{c}{ Conductivity $(\mu \mathrm{mhos} / \mathrm{cm})$} \\
\cline { 2 - 6 } H Area & HSP008 & HSP029 & HSP043 & HSP060 & HSP092 \\
\hline Mar 89 & 556 & 257 & 413 & 473 & ND \\
May 92 & 334 & 234 & 294 & 274 & ND \\
Jul 92 & 237 & 97 & 155 & 173 & 33
\end{tabular}

\begin{tabular}{lccccc} 
& \multicolumn{5}{c}{ Conductivity $(\mu \mathrm{mhos} / \mathrm{cm})$} \\
\cline { 2 - 6 } FArea & FSP012 & FSP032 & FSP047 & FSP204 & FSP290 \\
\hline Mar 89 & 30 & 174 & 52 & 895 & 49 \\
May 92 & 58 & 138 & 125 & 311 & 28 \\
Jul 92 & 106 & 95 & 88 & 277 & 46
\end{tabular}

Table A-5. Summary of $\mathrm{pH}$ Measurements

\begin{tabular}{lccccc} 
& \multicolumn{5}{c}{ pH } \\
\cline { 2 - 6 } H Area & HSPO08 & HSP029 & HSP043 & HSP060 & HSP092 \\
\hline Mar 89 & 5.7 & 5.2 & 5.3 & 5.9 & ND \\
May 92 & 5.6 & 6.1 & 6.2 & 5.6 & ND \\
Jul 92 & 6.32 & 4.8 & 5.73 & 6.07 & 5.68
\end{tabular}

\begin{tabular}{lccccc} 
& \multicolumn{5}{c}{ PH } \\
\cline { 2 - 6 } F Area & FSP012 & FSP032 & FSP047 & FSP204 & FSP290 \\
\hline Mar 89 & 5.3 & 5 & 4.7 & 4.4 & 3.6 \\
May 92 & 5.4 & 4.3 & 4.6 & .4 & 4.8 \\
Jul 92 & 5.14 & 4.1 & 5.38 & 5.35 & 4.83
\end{tabular}


Figures A-1 and A-2 illustrate the conductivity measurements collected from $\mathrm{H}$ Area and F Area, respectively. A general trend of decreasing conductivity is evident in $\mathrm{H}$ Area. This decreasing trend is not seen in F Area. The conductivity measurements at sample locations FSP032 and FSP204 in F Area show a decreasing trend in conductivity. The measurements at sample location FSP012 show an increasing trend. The measurements at sample locations FSP047 and FSP290 show no decreasing or increasing trend. The average background conductivity of the seepline water collected during this sampling event was
$29.5 \mu \mathrm{mhos} / \mathrm{cm}$. Ninety-six percent of the data presented in Table A-4 exceeds this background conductivity value.

Figures $\mathrm{A}-3$ and $\mathrm{A}-4$ illustrate the $\mathrm{pH}$ measurements collected from $\mathrm{H}$ Area and $\mathrm{F}$ Area, respectively. No specific trend is evident in either of these figures. The average background $\mathrm{pH}$ of the seepline water collected during this sampling event was 4.91. Sixty-five percent of the data presented in Table A-5 has a pH measurement which is greater than 4.91 .

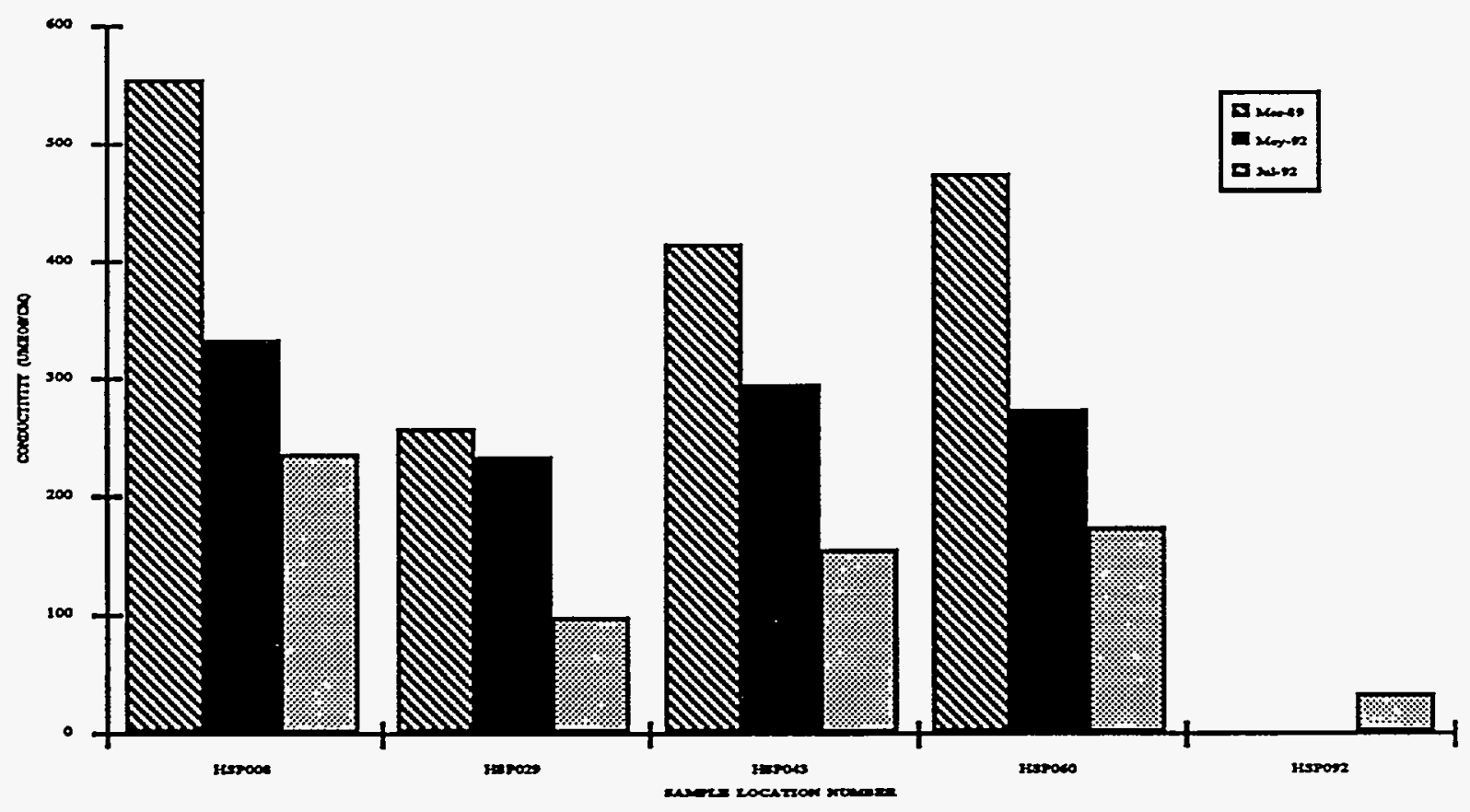

Figure A-1. Conductivity Measurements in H Area 


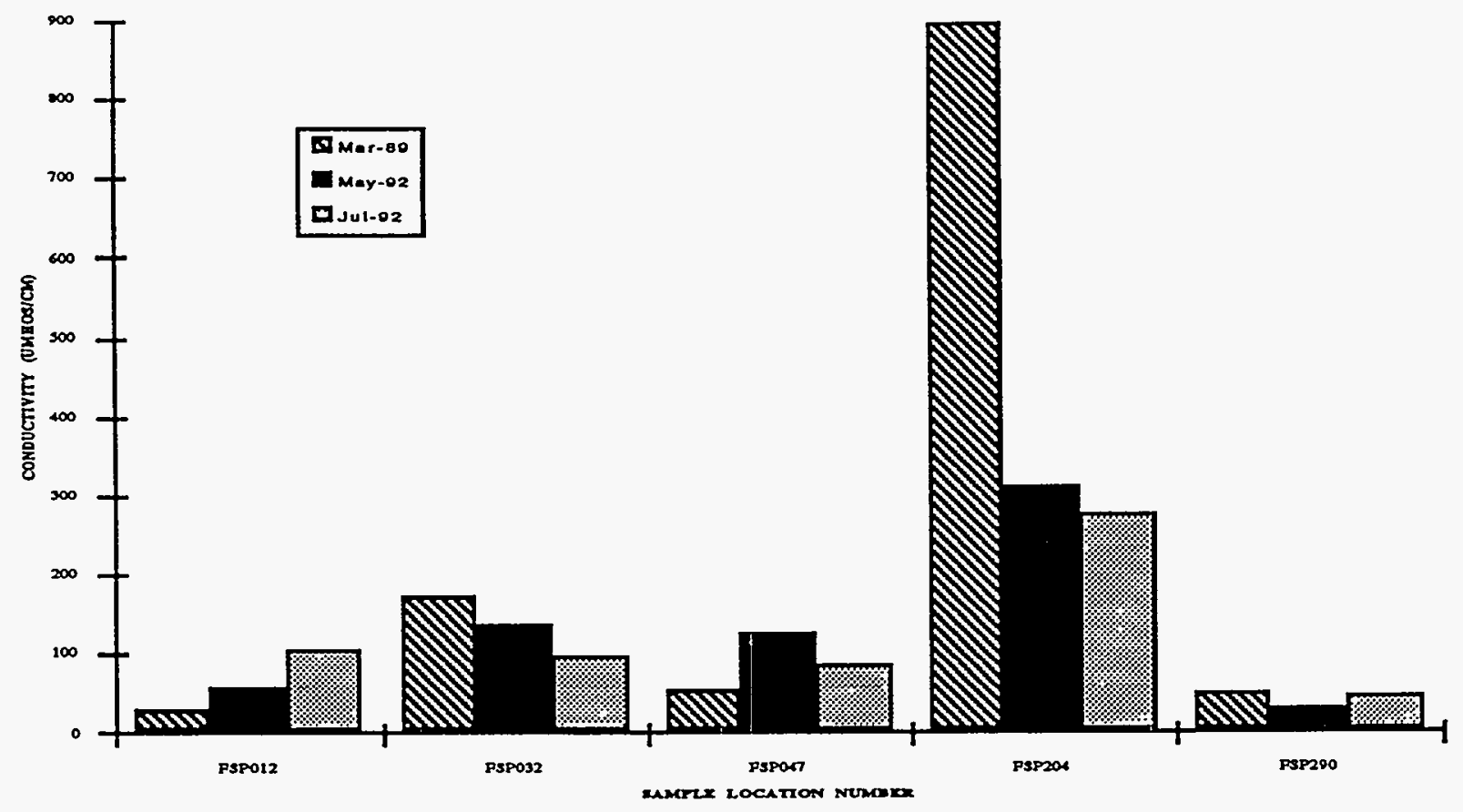

Figure A-2. Conductivity Measurements in F Area

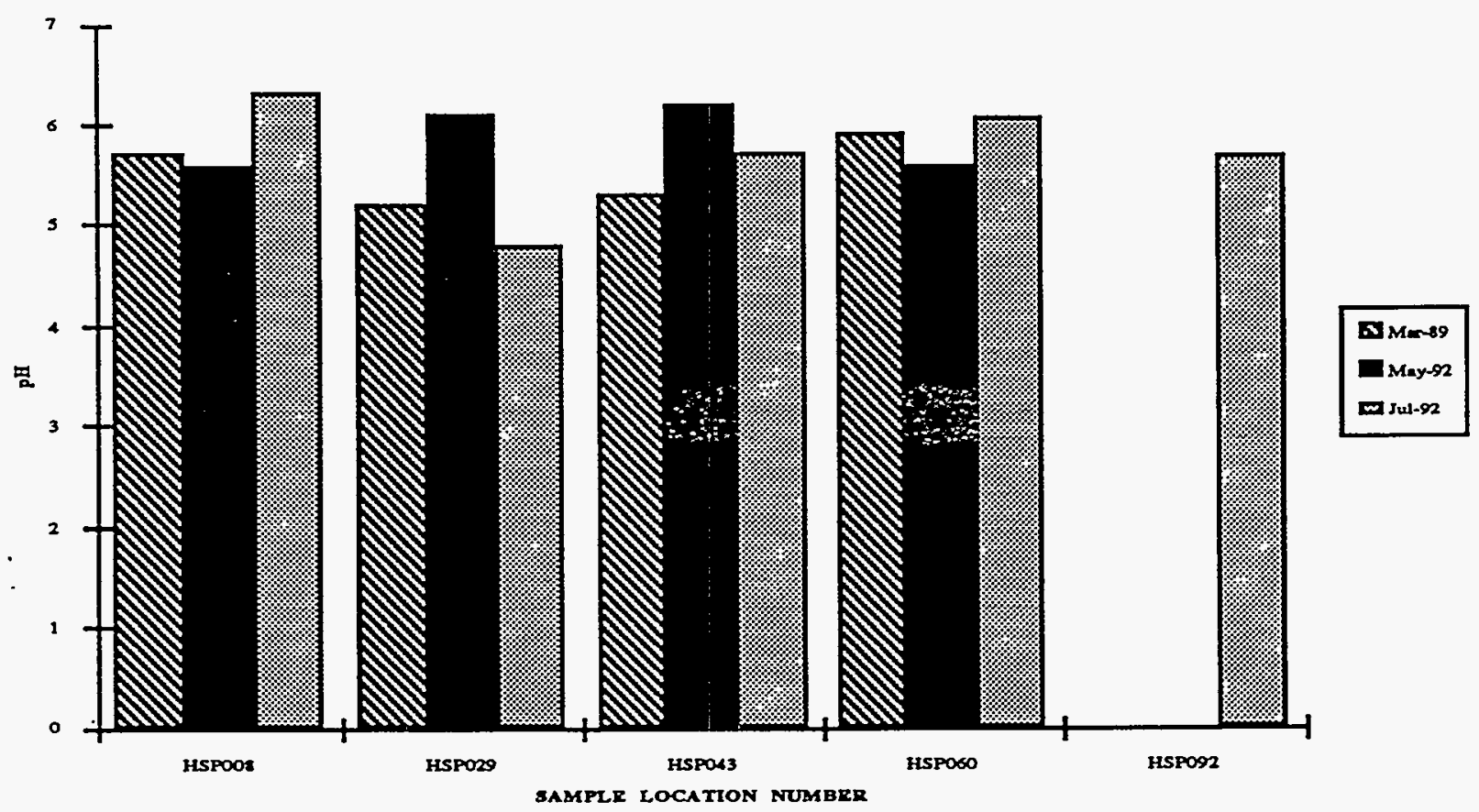

Figure A-3. $\mathrm{pH}$ Measurements in H Area 


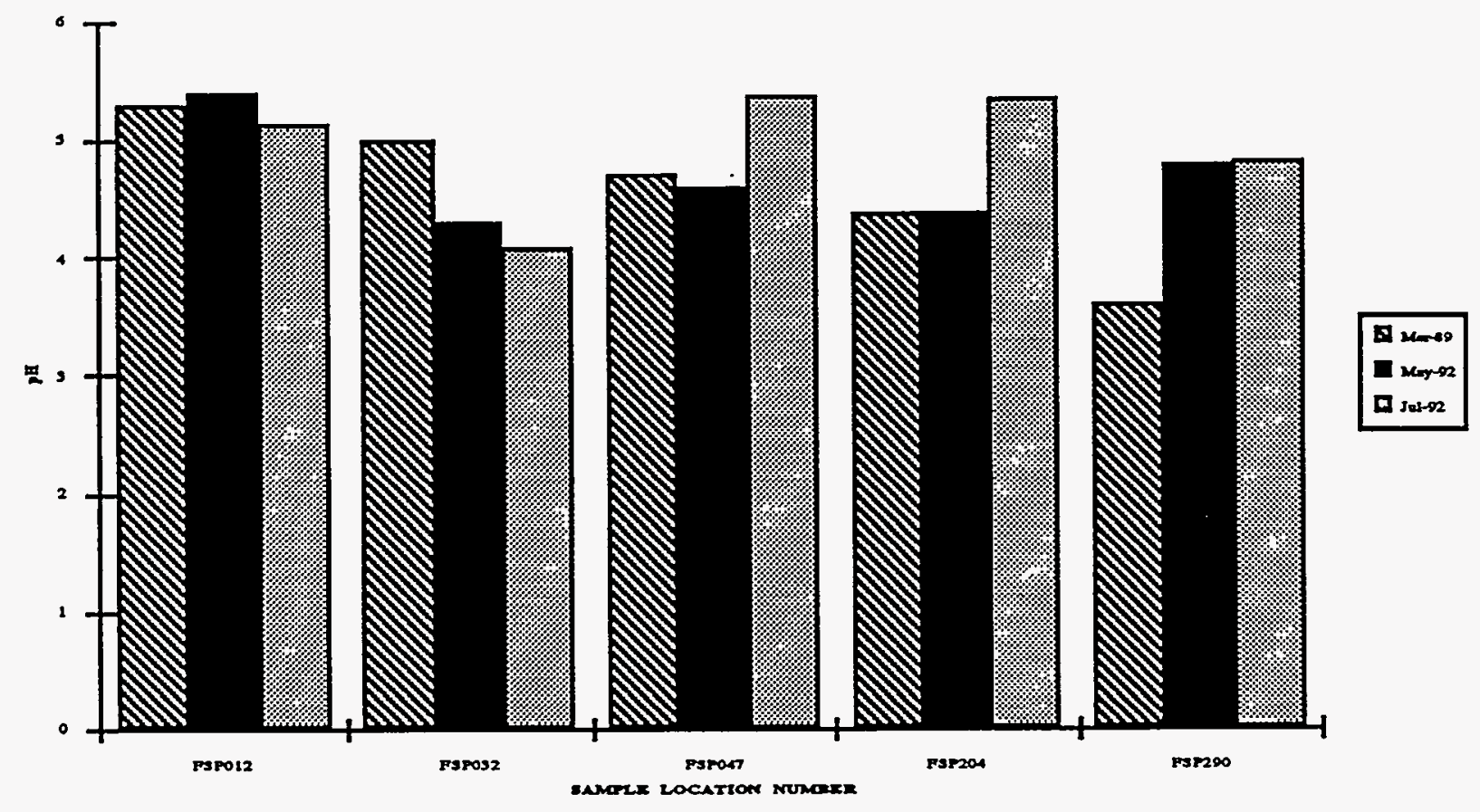

Figure A-4. $\mathrm{pH}$ Measurements in F Area

The background stream measurement for $\mathrm{pH}(5.80)$ and conductivity $(20 \mu \mathrm{mhos} / \mathrm{cm})$ was exceeded in all of the downgradient stream samples.

There is no historical data available on redox potential; thus, we cannot assess any possible trends at this time. However, the average background redox potential of the seepline water collected during this sampling event was $200 \mathrm{mV}$. Twenty percent of the data presented in Table A-3 has a redox potential measurement that is greater than 200 $\mathrm{mV}$. The redox potential of the background stream water was $-13 \mathrm{mV}$. The redox potential of the down stream sites were significantly higher than $-13 \mathrm{mV}$.

Metcalf and Eddy conducted a surveillance of the sampling procedures to verify that sampling was being conducted in accordance with the approved task-specific Quality Assurance Project Plan. The results of this surveillance is provided in Appendix B of WSRC-TR-92-559. 
WSRC-TR-93-289 


\section{Conclusions}

The average $\mathrm{pH}$ and conductivity values measured during this field event for F Area seepline samples, H Area seepline samples, and the stream samples are higher than the average $\mathrm{pH}$ and conductivity of the background seepline and stream water samples. The average redox potential of both F Area and $\mathrm{H}$ Area seepline samples is less than the average redox potential of the background seepline sample. However, the redox potential of the background stream water was lower than the average redox potential of the downgradient stream samples.

Historical trends indicate decreasing conductivity measurements in $\mathrm{H}$ Area seepline samples. No trends are evident in the conductivity measurements for the $F$ Area seepline.

Historical $\mathrm{pH}$ measurements in both $\mathrm{F}$ Area and $\mathrm{H}$ Area seepline samples show no general trends. There is no historical information available regarding the redox potential of the seepline or stream water samples.

\section{References}

Haselow, J. S., M. Harris, B. B. Looney, N. V. Halverson, and J. B. Gladden. 1990. Analysis of soil and water at the Fourmile Branch seepline near the F and $\mathrm{H}$ Area of the SRS (U). WSRC-RP-90-0591, Savannah River Laboratory, Aiken, South Carolina.

Dixon, K. L. and V. A. Rogers. Results of the first quarter tritium survey of the F- and H-Area seeplines: May 1992 (U). WSRC-TR-92-304, Savannah River Technology Center, Aiken, South Carolina. 
WSRC-TR-93-289 


\section{Appendix B}

\section{Plots of Analyte Concentrations as a Function of Seepline Areas}


WSRC-TR-93-289 


\section{Introduction}

The following plots are of analyte concentrations as a function of seepline area for those analytes on which statistical analysis was performed. The plots were prepared using the untransformed concentration data and should provide the reader a view of the variability associated with each analyte. The dashed line observed in each plot represents the mean of all data points (BG, FSP, HSP combined) for that analyte. 


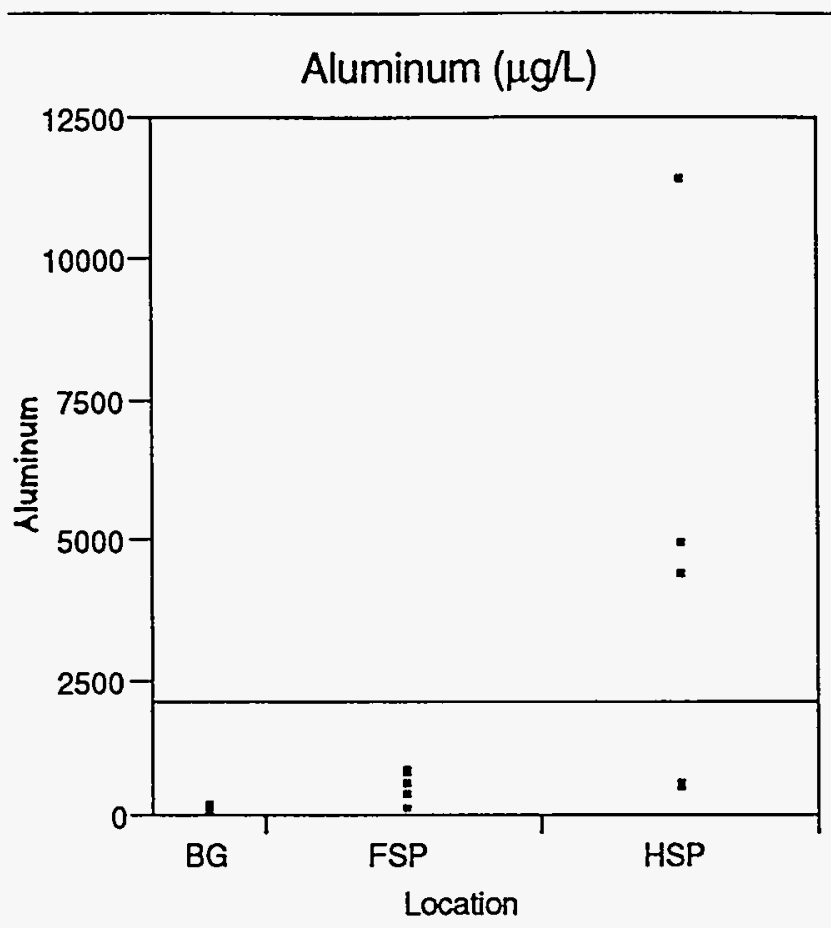

Figure B-1. Aluminum ( $\mu \mathrm{g} / \mathrm{L})$

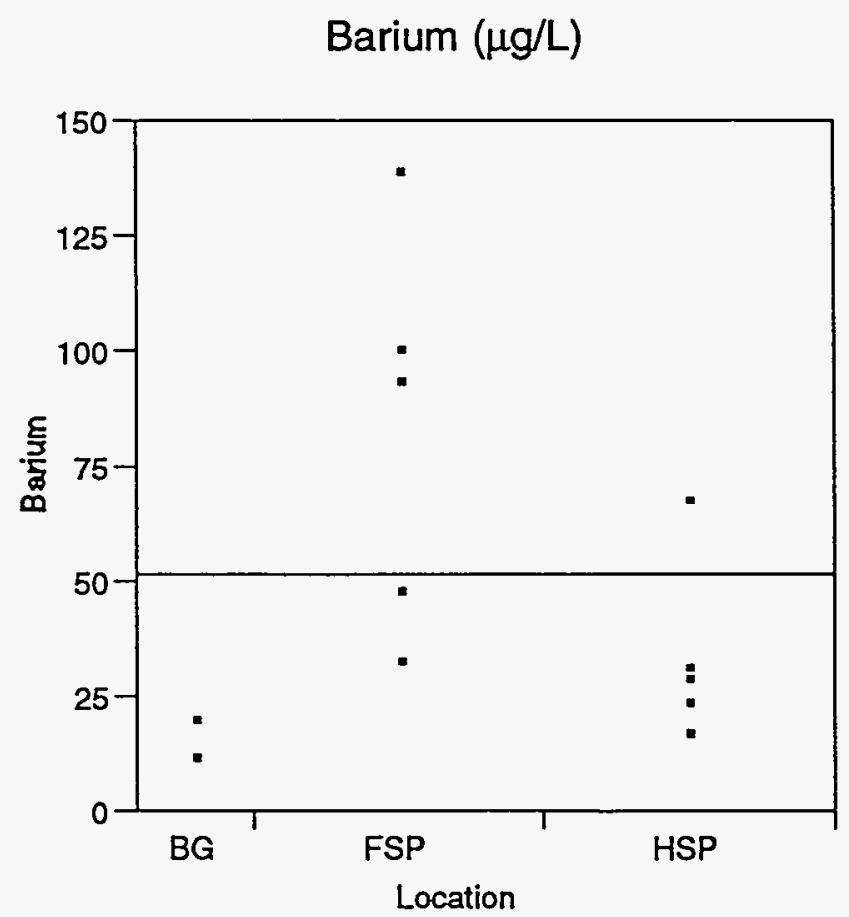

Figure B-3. Barium $(\mu g / L)$

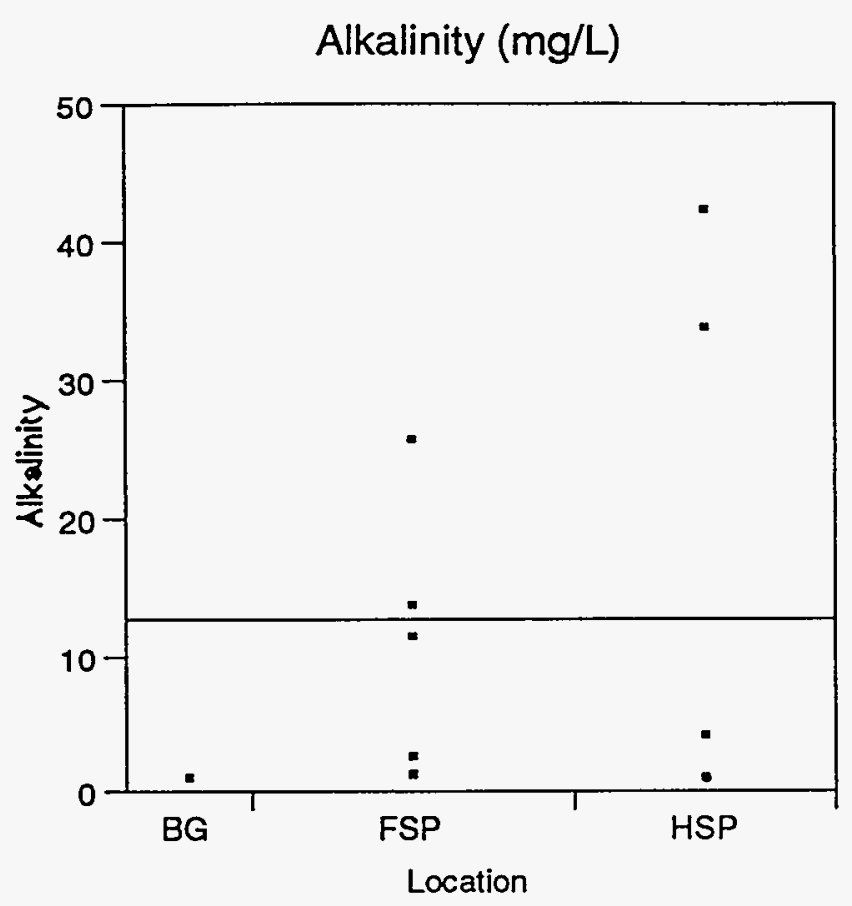

Figure B-2. Alkalinity (mg/L)

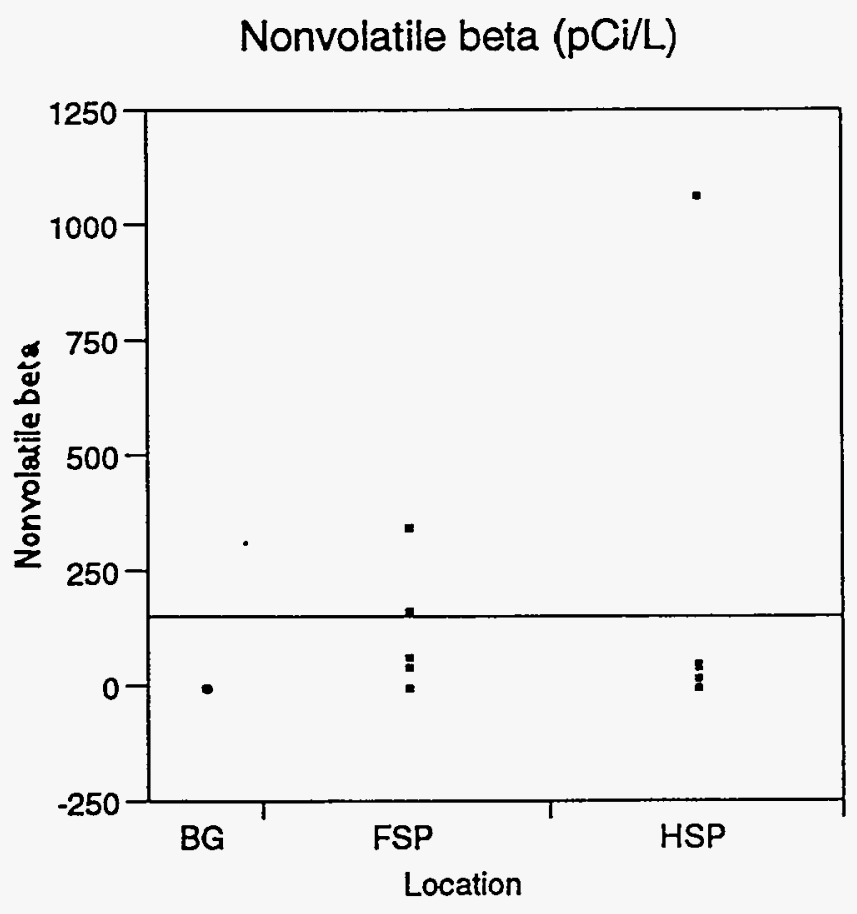

Figure B-4. Nonvolatile beta ( $\mathrm{pCi} / \mathrm{L})$ 


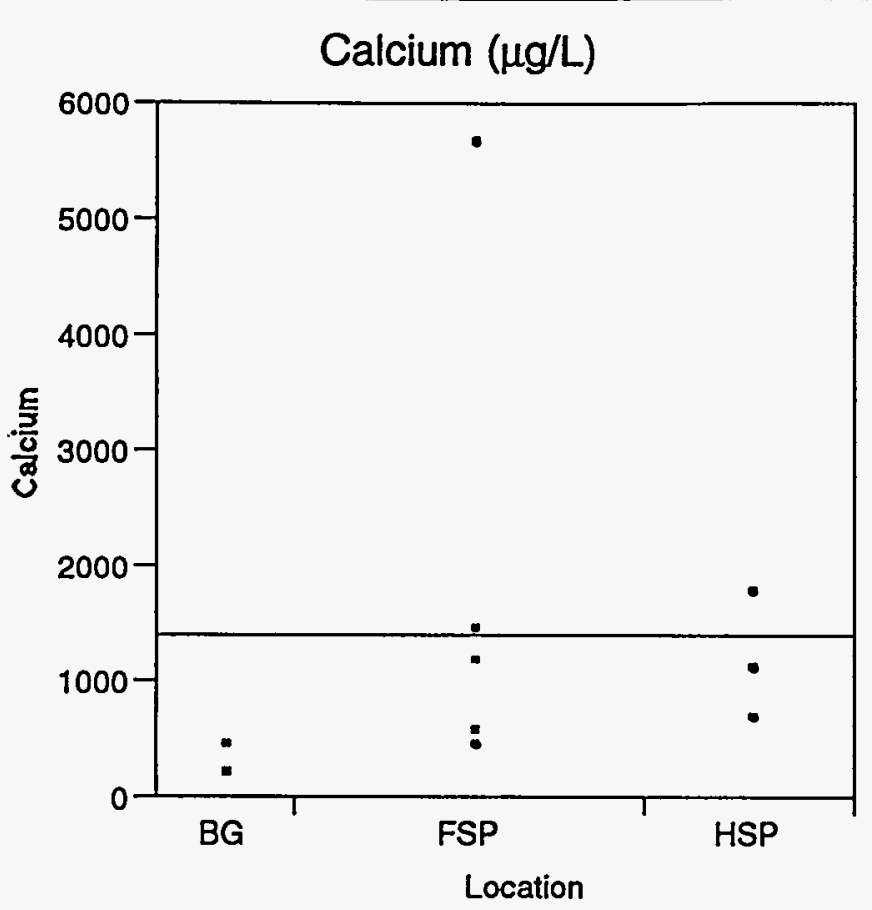

Figure B-5. Calcium $(\mu \mathrm{g} / \mathrm{L})$

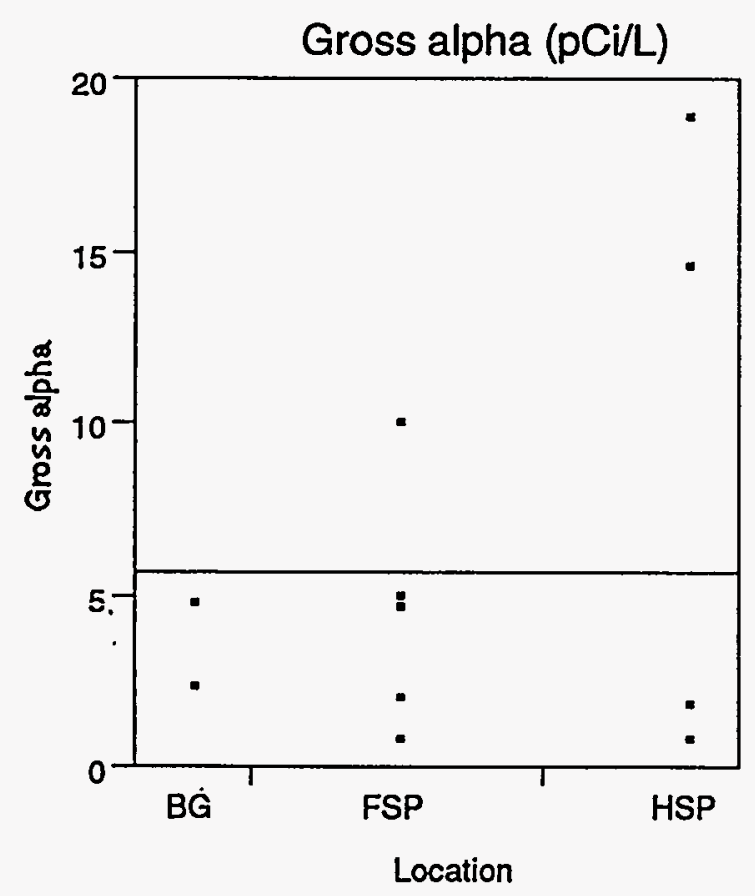

Figure B-7. Gross alpha (pCi/L)

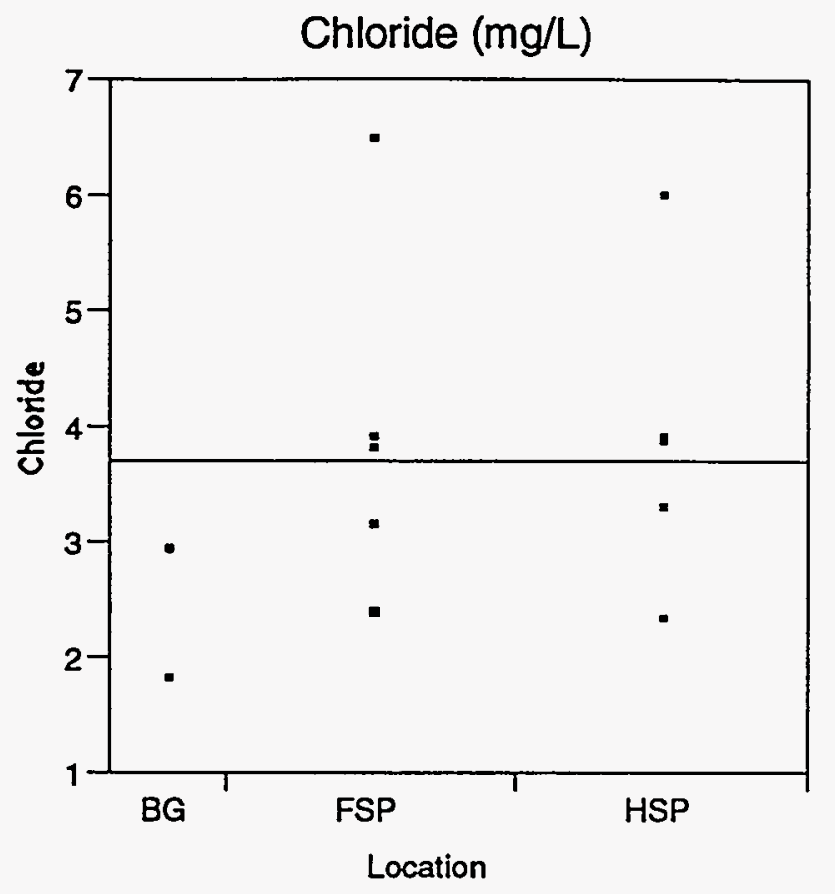

Figure B-6. Chloride (mg/L)

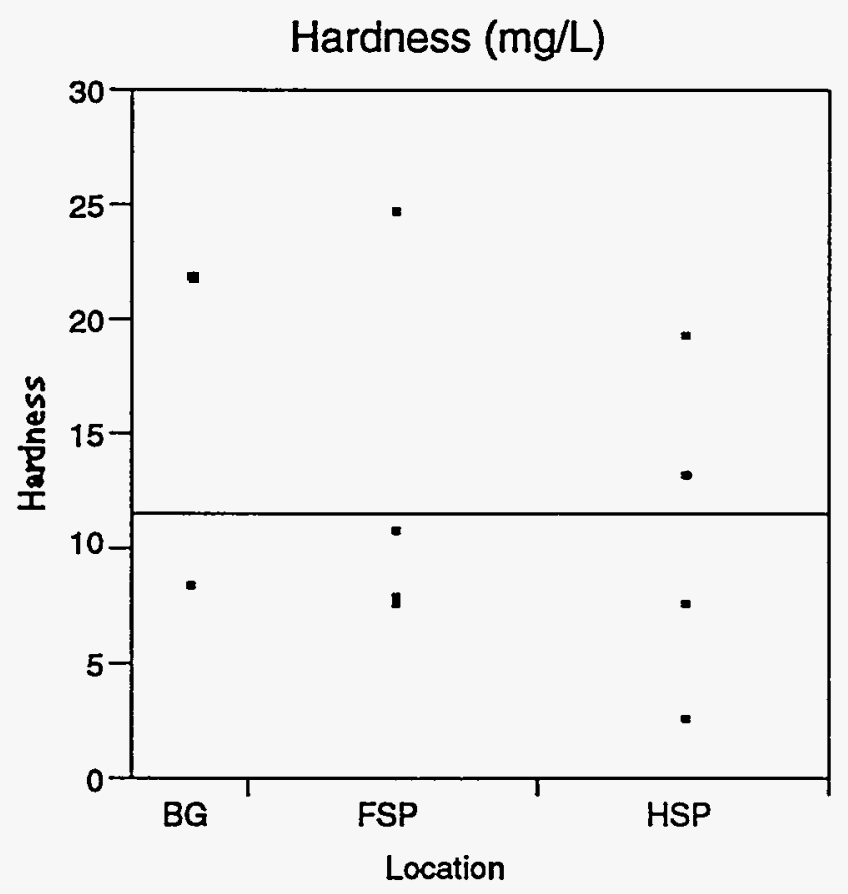

Figure B-8. Hardness (mg/L) 


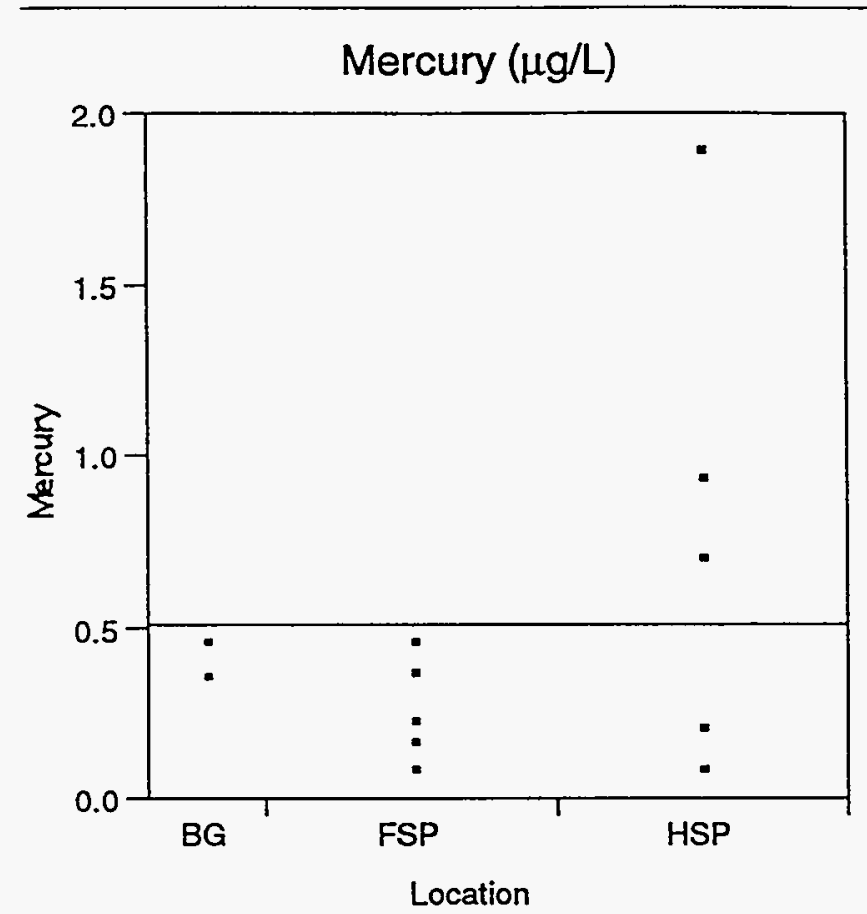

Figure B-9. Mercury $(\mu g / L)$

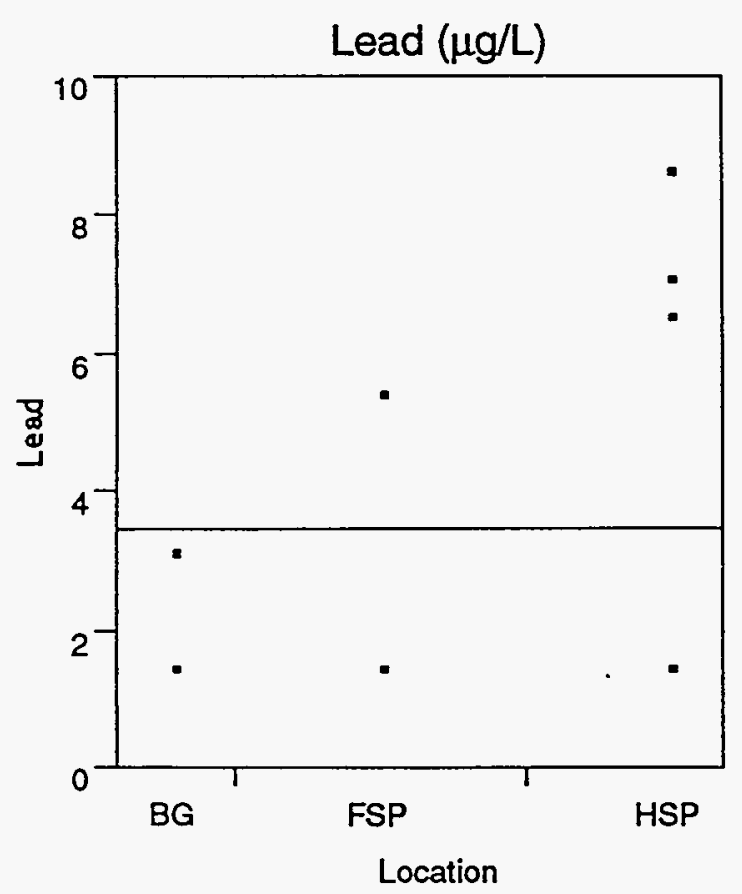

Figure B-11. Lead $(\mu g / L)$

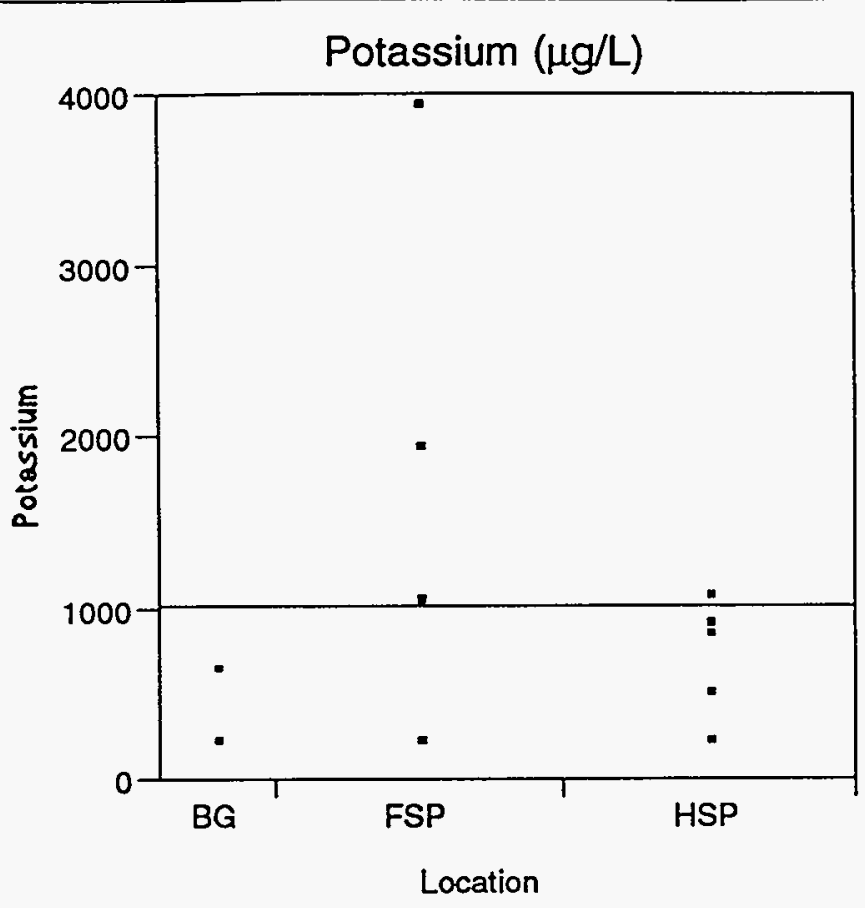

Figure B-10. Potassium $(\mu \mathrm{g} / \mathrm{L})$

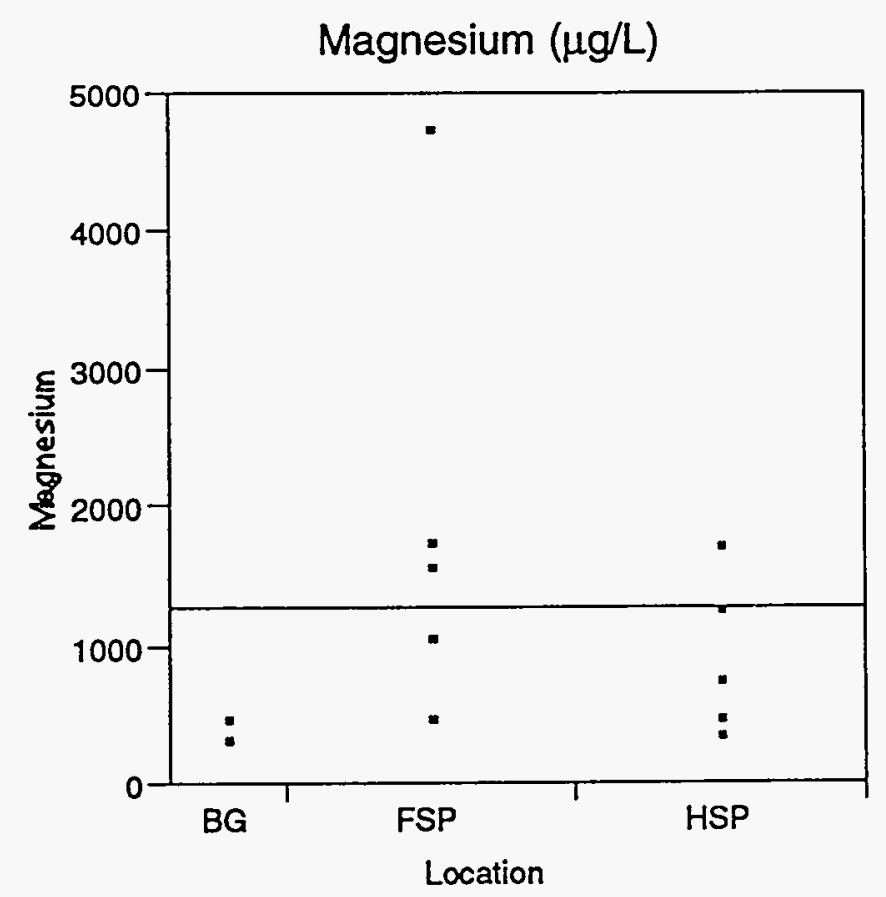

Figure B-12. Magnesium $(\mu \mathrm{g} / \mathrm{L})$ 

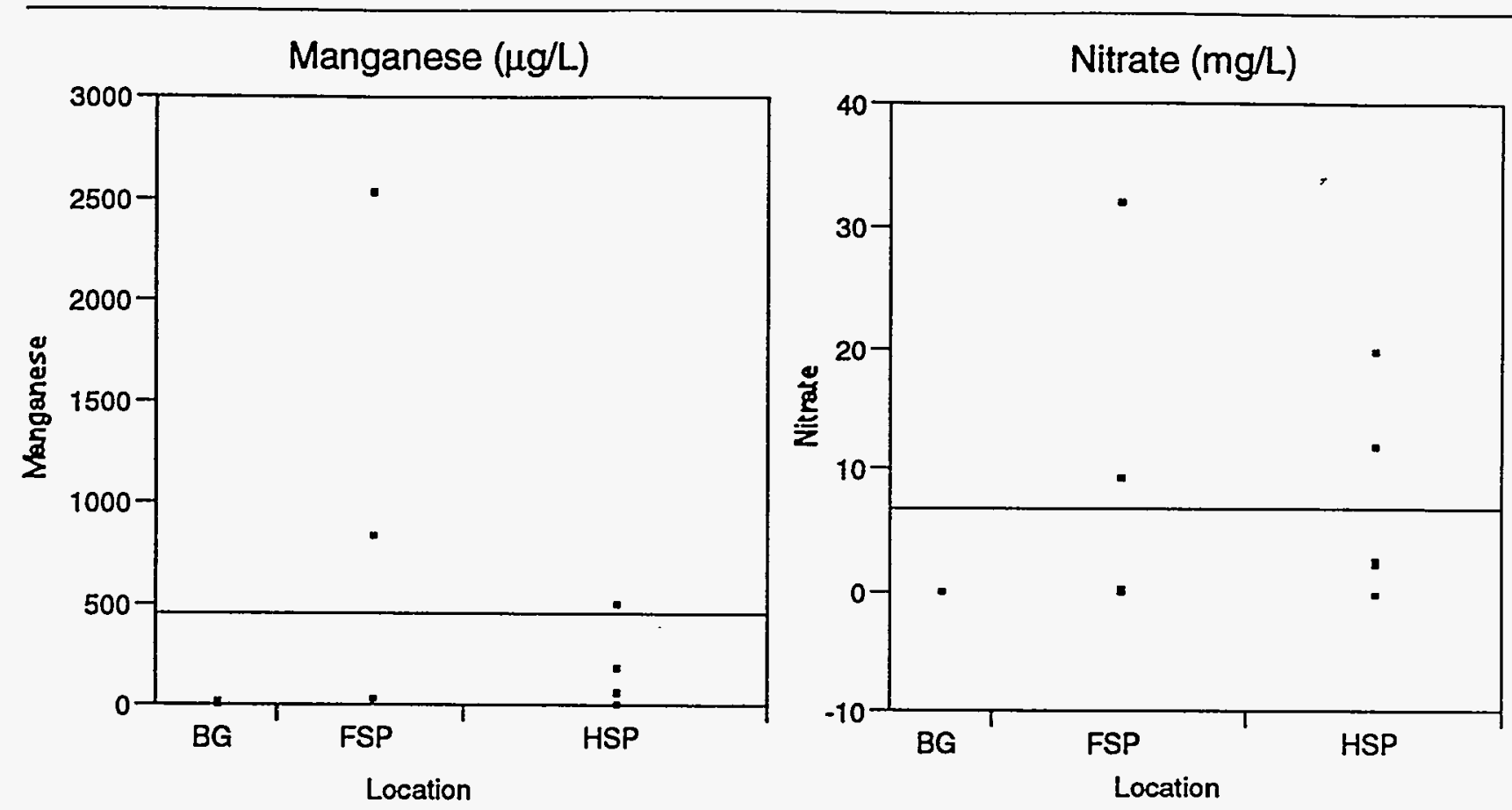

Figure B-13. Manganese $(\mu g / \mathrm{L})$

Figure B-14. Nitrate (mg/L)
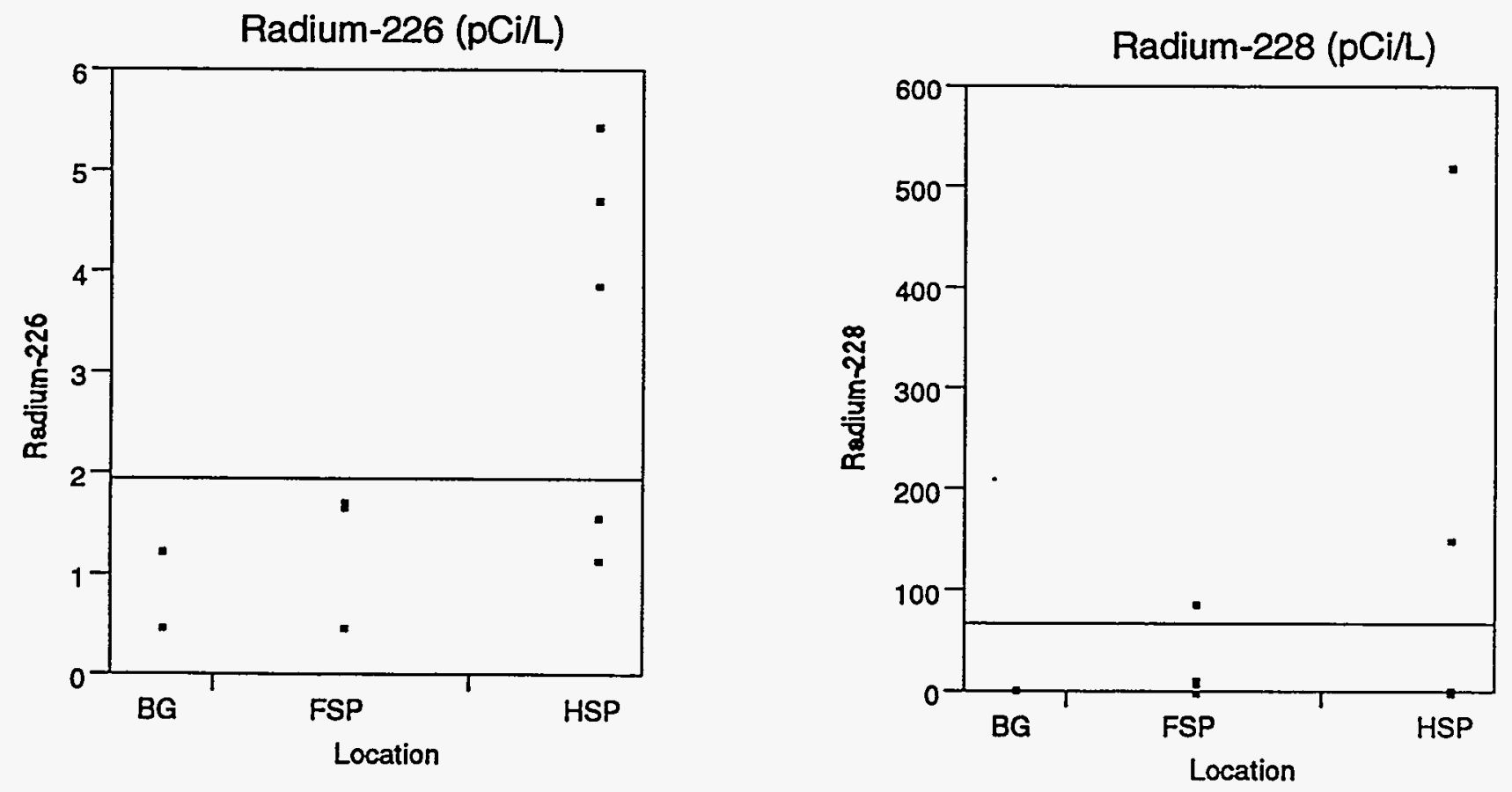

Figure B-15. Radium-226 (pCi/L)

Figure B-16. Radium-228 (pCi/L) 


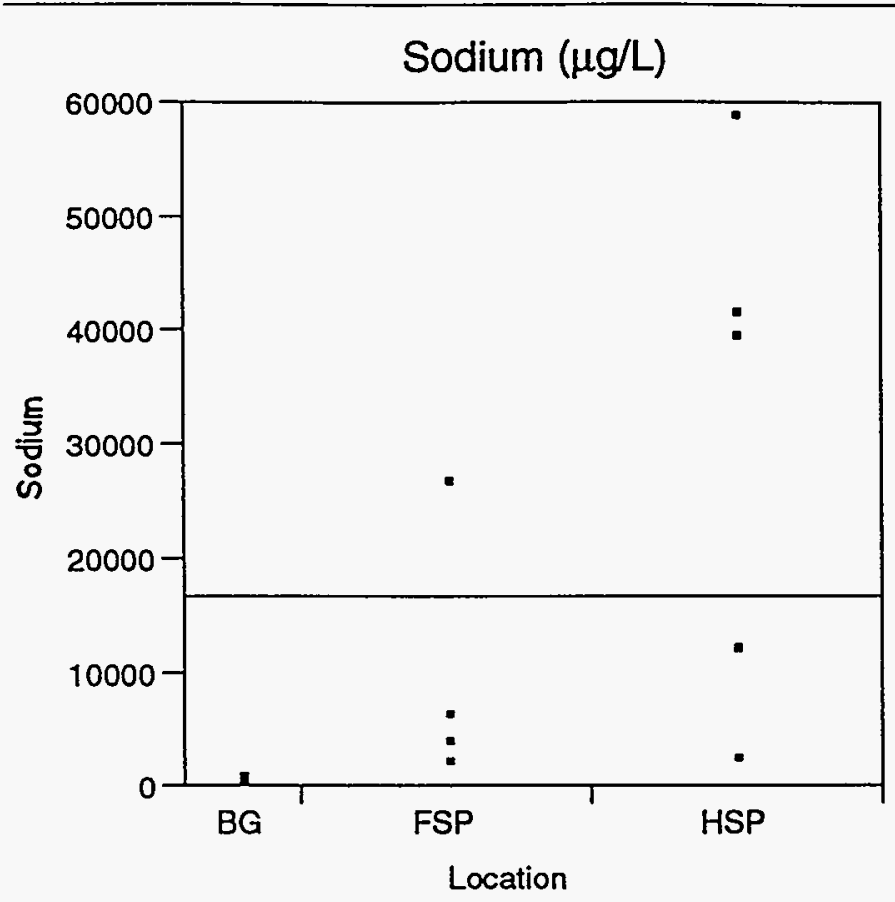

Figure B-17. Sodium ( $\mu g / \mathrm{L})$

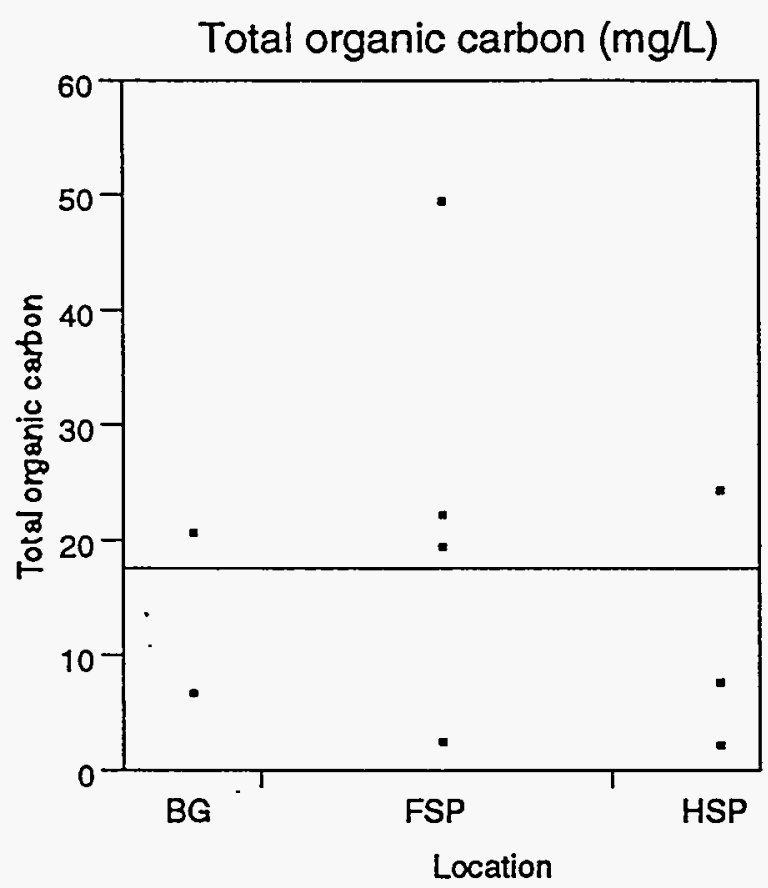

Figure B-19. Total organic carbon (mg/L)

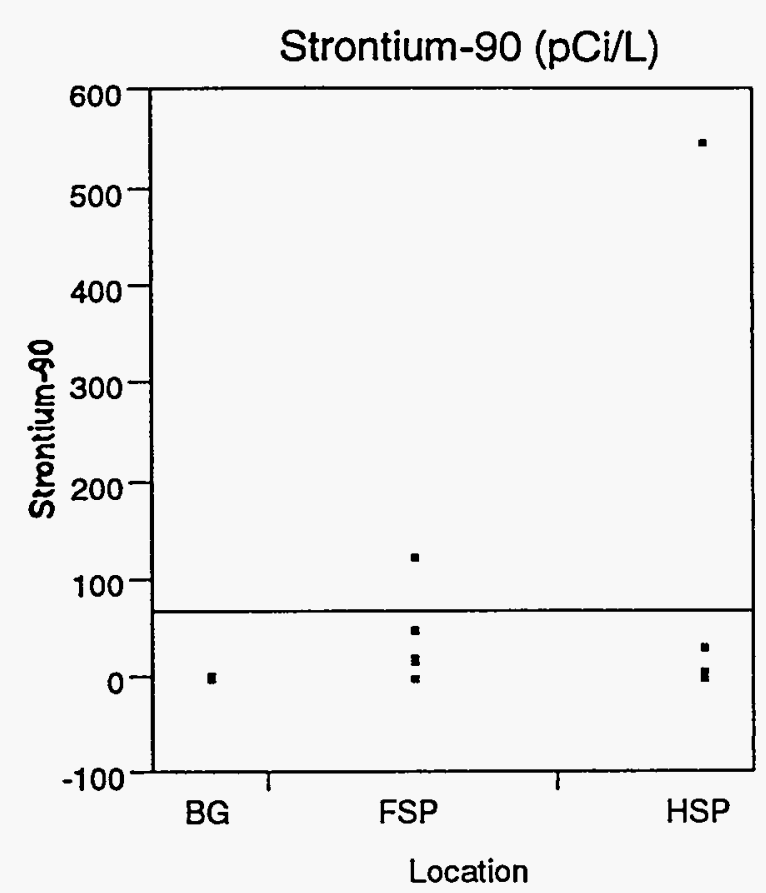

Figure B-18. Strontium- 90 (pCi/L)

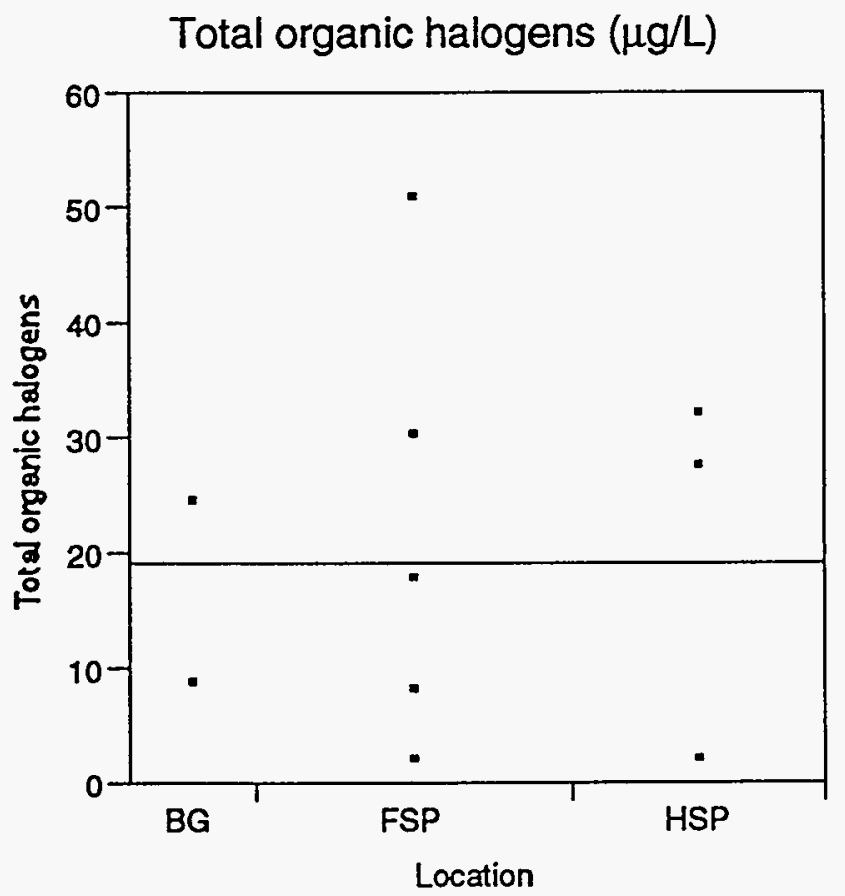

Figure B-20. Total organic halogens $(\mu g / L)$ 


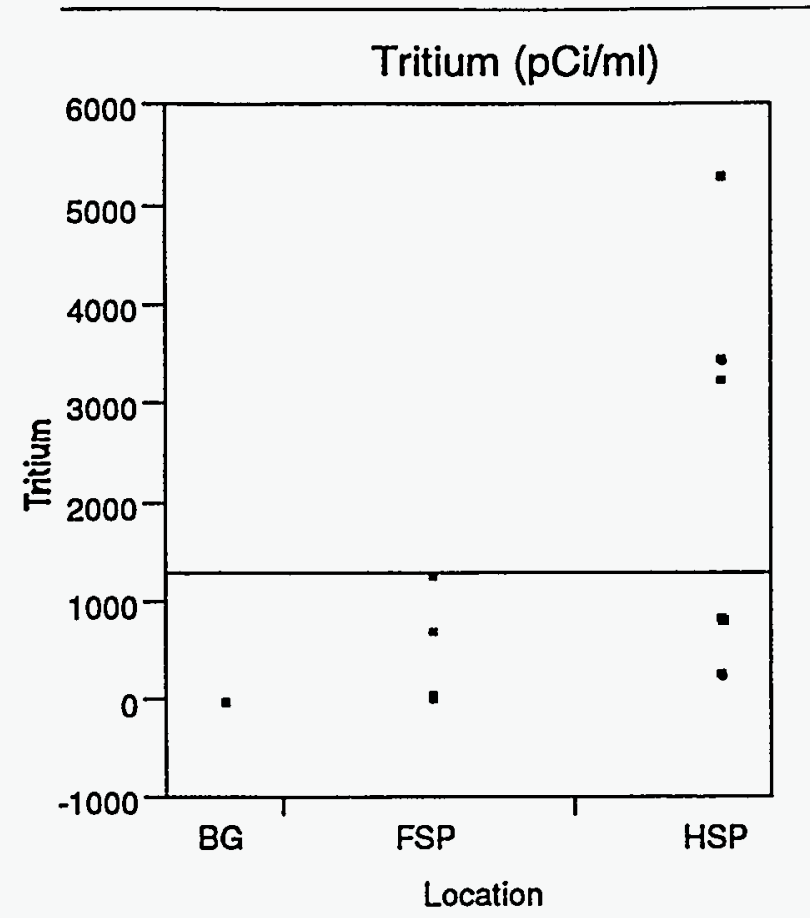

Figure B-21. Tritium (pCi/ml)

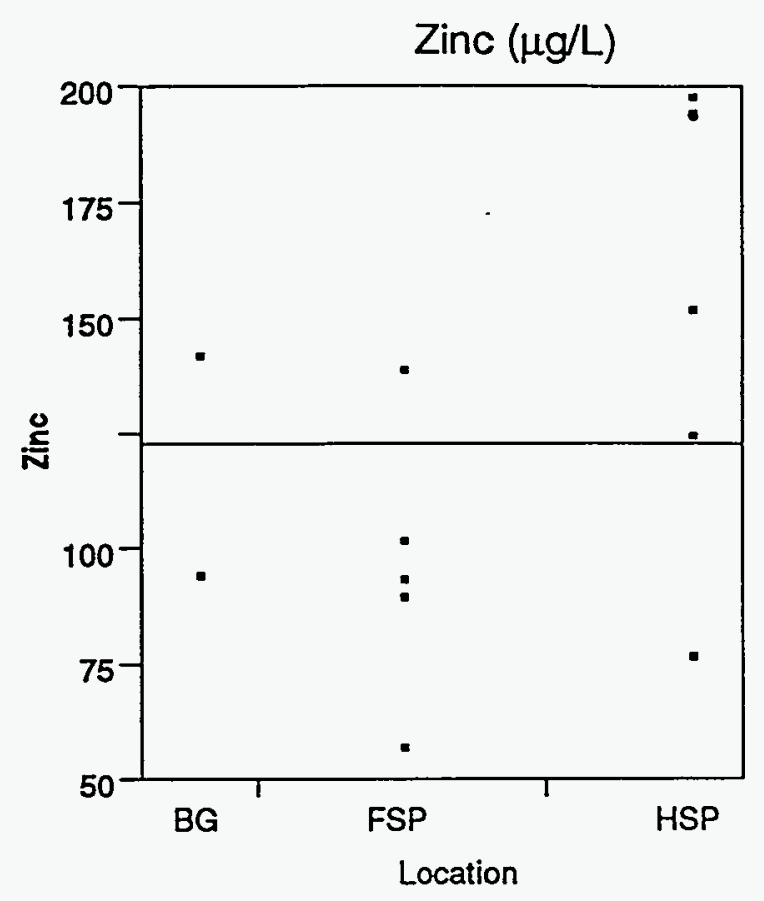

Figure B-22. Zinc $(\mu \mathrm{g} / \mathrm{L})$ 